\author{
UNIVERSIDADE DE SÃO PAULO \\ FACULDADE DE FILOSOFIA, LETRAS E CIÊNCIAS HUMANAS \\ DEPARTAMENTO DE LETRAS ORIENTAIS \\ PROGRAMA DE PÓS-GRADUAÇÃO EM LITERATURA E CULTURA RUSSA
}

POLYANA DE ALMEIDA RAMOS

(polyana.ramos@usp.br)

Gorie ot uma, de Aleksandr Griboiédov

Tradução e Aproximações

Versão Corrigida

SÃO PAULO

2010 


\author{
UNIVERSIDADE DE SÃO PAULO \\ FACULDADE DE FILOSOFIA, LETRAS E CIÊNCIAS HUMANAS \\ DEPARTAMENTO DE LETRAS ORIENTAIS \\ PROGRAMA DE PÓS-GRADUAÇÃO EM LITERATURA E CULTURA RUSSA
}

\title{
Gorie ot uma, de Aleksandr Griboiédov \\ Tradução e Aproximações
}

Polyana de Almeida Ramos

Dissertação apresentada junto à área de Literatura e Cultura Russa da Faculdade de Filosofia, Letras e Ciências Humanas, com vista à obtenção de título de Mestre em Letras.

Orientadora: Profa Dr. ${ }^{a}$ Arlete Orlando Cavaliere

\author{
Versão Corrigida \\ SÃO PAULO
}

2010 


\section{Resumo}

O presente trabalho é composto pela apresentação de $A$ inteligência, que desgraça! (1825), do dramaturgo russo Aleksandr Serguéievitch Griboiédov, do universo em que foi escrita, bem como a tradução da obra-prima ao português. Essa primeira tradução carrega os dilemas inerentes à grandiosidade da linguagem e, sendo assim, o primeiro passo, na tradução da obra ao português, segue o caminho do significado para que, no futuro, o significante, complexo e rico, possa ser focado. Depois, tomamos o caminho do Teatro Russo do século XVIII e início do século XIX, seu universo neoclássico, e, ao final, as transfigurações de $A$ inteligência, que desgraça! aos modelos clássicos, essencialmente os conflitos provenientes das ações que trabalham, nas duas tramas principais, de maneira igual.

Palavras-chave: Aleksandr Griboiédov; $A$ inteligência, que desgraça!; Teatro Russo do século XVIII; Teatro Russo no início do século XIX; Neoclassicismo; Teatro Russo. 


\section{Abstract}

This present research is composed of a presentation of Gore ot uma (1825), by Russian playwright Aleksandr Griboedov, and of the universe in which it was written, as well as a first step in attempt of translating the masterpiece into Portuguese. This first translation embodies the dilemmas inherent to the greatness of the language and, therefore, the first step, for a translation of the masterpiece into Portuguese, follows the path of the signified, in order that, in the future, the signifier, rich and complex, may be focused. Afterwards, we take the path of Russian Theater from the Eighteenth century to the beginning of Nineteenth century, its neoclassical universe, and, in the end, in Gorie ot uma's transfigurations to the classical patterns, essentially the conflicts originated by actions that work, in the two main plots, in a equal manner.

Keywords: Aleksandr Griboedov; Gore ot uma; Russian Theater in Eighteenth-century; Russian Theater in the beginning of Nineteenthcentury; Neoclassicism; Russian Theater 


\section{Agradecimentos:}

Aos portadores de conhecimento e experiência, em auxílio, por todos esses anos:

Prof.Dra Arlete Orlando Cavaliere

Prof.Dr. Noé Silva

Prof.Dr. Bruno Gomide

Prof.Dr. Homero Freitas de Andrade

À Capes (Coordenação de Aperfeiçoamento Pessoal de Nível Superior), pela bolsa a mim concedida.

Ao Prof. Dmitri Guriévitch e à Kátia Volkova Américo, que me nortearam nos meandros do russo em Gorie ot uma, de Aleksandr Griboiédov. E, aproveitando ensejo, agradeço à Denise, excelente professora do idioma, uma personalidade cativante!

Aos colegas do Curso de Russo, tão especiais: Deise, Daniela, Priscila, Cecília, Gabriela, Loreta.

E aos que, em meu coração, encontram e encontrarão sempre guarida:

Minha família, com muito amor: Papai, Mamãe, Patricia, Priscila, Rodrigo e Fabiana. 
Aos "tchuriros" de toda a minha vida: Tula, Susi, Ben-hur, Deutsch, Sansão e Dalila.

Aos amigos, confidentes e companheiros nesta trajetória: Ângela, Amauri, Boris, Elaine, Elisabetta, João Marcelo, Jota, Juliana Petersen, Juliana Uetsuki, Luciana, Márcio, Priscilla, Renata, Viviane.

Obrigada! 


\section{SUMÁRIO}

APRESENTAC̄̃̃O 9

A. S. GRIBOIÉDOV: UMA TRAJETÓRIA 12

Parte I - Tradução de Gorie ot uma, Aleksandr Griboiédov 27

DILEMAS DA TRADUCÃ̃O DE GORIE OT UMA, DE ALEKSANDR GRIBOIÉDOV 28 TRADUÇ̃̃O 31

NOTAS À TRADUCÃO DE GORIE OT UMA, DE ALEKSANDR GRIBOIÉDOV 187

Parte II - Caminho Crítico 206

OS PAVIMENTOS 207

O CAMINHANTE 233

A ESTRADA 254

REFERÊNCIAS BIBLIOGRÁFICAS 285 
"A classic is classic not because it conforms to certain structural rules, or fits certain definitions (of which its author had quite probably never heard). It is classic because of a certain eternal and irrepressible freshness".

(Ezra Pound) ${ }^{1}$

${ }^{1}$ POUND, Ezra - ABC of Reading - London: Faber and Faber, 1934, pp. 13-14. 


\section{Apresentação}

Quando fui apresentada à obra Горе от ума (Gorie ot uma, A inteligência, que desgraça!, 1825), de Aleksandr Griboiédov, cursava ainda uma disciplina de Teatro Russo, componente à grade curricular do Curso de Russo, na graduação. A ausência de uma tradução ao português e a importância da obra no original aguçaram meus instintos de desbravamento e, sendo assim, mediante o auxílio de minha orientadora, a Dra. Arlete Orlando Cavaliere, senti-me instigada em prosseguir o intento de reclamar, em um Mestrado, essa ausência.

A obra, que já pude ler, ainda naquela época, em inglês, continha um caráter sutil, levemente romanesco, e, por vezes, parecia-se com muitas obras que já havia lido em algum momento. 0 herói romântico em busca da amada, os quiproquós para alcançar o objetivo, os vilões que entremeavam as ações dos protagonistas, e o final melancólico, eram traços comuns ao Cânone de muitas literaturas mundo afora. Mas havia algo, um elemento indefinido até hoje, que ofertava uma significância ainda maior, para mim, ao ler a peça russa.

Fui, aos poucos, aproximando-me das bases em que a peça foi escrita, do período que ela encerrava e dava abertura para que grandes obras como as de Púchkin e Gógol tivessem maior relevância. $O$ contexto em que fora escrita, bem como as polêmicas que envolviam a vida do autor, fizeram com que mais brilho e enigma fossem arregimentados em minha verve investigadora. O Movimento Dezembrista sempre fora um dos pontos mais enevoados, a meu ver, em meus estudos de História Russa, e, ao ler a peça, senti-me mais próxima do evento que muitos chamam de primeiro embrião revolucionário.

A paixão à peça de Griboiédov ia, aos poucos, aumentando constantemente, e o desafio em focá-la, no Mestrado, engrandecia as 
possibilidades de trazer, enfim, ao público brasileiro, a oportunidade de também encantar-se com aquele grande achado russo.

Enquanto ia conhecendo mais e mais sobre o autor Griboiédov, em biografias, e, sobre a época, em obras teóricas e históricas ocidentais, fui me irmanando e adentrando, totalmente, no universo de Gorie ot uma. Juntamente a isso, já no Mestrado, comecei a traduzir a peça, tarefa que fazia pausadamente, termo por termo.

A dificuldade da língua russa para um estudante não-nativo no idioma é tarefa sempre complexa e que demanda um esforço maior, seja pela discrepância entre a estrutura de nosso português e do russo, seja pela ambientação semântica distinta que pode advir de um mau uso de dicionários e gramáticas. Sendo sempre complexa a tarefa em esmiuçar um texto russo, principalmente literário, pensei deparar-me, em Gorie ot uma, com uma dificuldade semelhante a que encontrava em outras obras do século XIX ou XX.

No entanto, aos poucos, e com a obra já traduzida, junto a colegas, a professores, encontrei quadro diverso. A peça Gorie ot uma, de Aleksandr Griboiédov, não apresentava uma linguagem usual, comumente traduzida, como o foram outras obras. Ela apresentava "a" linguagem, por excelência, com riqueza e agilidade, com provérbios de quase impossível transposição, com um grau de elevação linguística muito sofisticado. Nuances entre as vozes das personagens, entre a destilação de versos mais complexos em conteúdo e mais complexos em forma, surgiram como elementos que não havia percebido durante o árduo caminho de tradução $\mathrm{e}$ transposição do significado dos versos.

Assim, apesar de haver acreditado que meu mestrado comporia uma tradução à peça Gorie ot uma, passei a, também, compreender que este era apenas um primeiro passo de vários, em prol de uma transposição que pudesse ao menos alçar uma pequena porcentagem da grandeza que a obra representa à literatura e cultura russa. 
A partir desse pensamento, torna-se imprescindível relembrar o caráter aproximatório do presente trabalho. Aproximação a um universo ainda a ser esmiuçado de maneira abrangente, tanto acerca de pontos não explorados no que concerne o aprofundamento da vida e obra de Griboiédov, quanto das possibilidades de transgressão e de radicalização da forma. São esses os passos iniciais para que possamos entrar, com toda a alma, no desafio de uma tradução, que possa abraçar a grandiosidade do conteúdo, palavra e música que, em Gorie ot uma, revezam as maestrias. 


\section{A. S. Griboiédov: uma trajetória}

Pensar em literatura russa antes da grande alvorada ofertada por Aleksandr Púchkin parece, talvez, ousadia de quaisquer pesquisadores que se propõem a estudá-la. Há quem responda a esses diletantes com uma pergunta: por que se debruçar sobre períodos tão inócuos quando a Rússia, em se tratando do século XIX, é firme chão de prolíferas raízes?

O século XIX, na literatura russa, foi berço para a arte mundial. Púchkin, com sua linguagem original e rica, abriu as portas para que grandes nomes como Liérmontov, Gógol, Dostoiévski, Turguéniev, Tolstói, Tchékhov, entre outros, brotassem para o mundo.

Os interessados nas belas-artes - sejam europeus, norteamericanos, ou brasileiros - exultam-se diante da grandeza de obras como O inspetor geral, Pais e filhos, Crime e Castigo, Anna Kariênina, A gaivota. Mas uma voz, tênue e gigantesca, parece apenas perceptível aos russos. Ela fala agilmente, dispõe-se em ritmo frenético, excitante, inesquecível. Dança por entre vinte e cinco tolos, e um homem inteligente. Viaja, apaixona-se, tropeça, levanta, enraivece-se. E desponta. Para fixar-se como infinita.

Para Ivan Gontcharov, o autor de Oblómov, essa voz assemelha-se a um velho de cem anos que, diferente dos que o 
acompanharam em seu tempo, caminha, vívido e frondoso, por entre o túmulo dos velhos e o berço dos novos. ${ }^{2}$

Para Stanislávski, o grande encenador russo, é esta a maior voz teatral russa.

Para Simon Karlinsky, estudioso da arte russa, a voz espalhouse como nenhuma outra, tornando-se a mais citada e difundida pelos escritores posteriores.

Para Iúri Tyniánov ${ }^{3}$, grande teórico russo, que devotou parte de seus estudos a desvendá-la, a voz fala "sobre aquele época difícil, sobre o poder das mulheres e declínio do homem, sobre o grande resultado histórico em prol da guerra heroica do povo: pela liberdade dos camponeses, pela grande cultura nacional, pelo poderio militar do povo russo - um resultado a liquidar, que levaria a dezembro $1825^{\prime \prime}$.

Para Anatóli Lunatchárski ${ }^{5}$, no fervor de seu universo soviético, há uma força da linguagem engrandecida por essa voz, na época em que a língua russa ganhava bases e força linguística. Pode-

\footnotetext{
2 Primeiro grande excerto do famoso ensaio de Gontcharov, acerca da peça Gorie ot uma (GONTCHAROV, I. A. "Мильон терзаний" (Mil'on tierzanii, Um milhão de tormentos). Sobránie Sotch., T. VIII, Moskva: 1952. (http://az.lib.ru/g/goncharow_i_a/text_0040.shtml; acesso em 20/04/2007)) ${ }^{3}$ Iúri Tyniánov (1894-1943) - escritor, teórico literário e tradutor russo. Escreveu diversas obras de vertente teórico-literária. Escreveu, também, um romance biográfico a Griboiédov, Смерть Вазир-Мухтара (Smiert Vazir-Mukhtara, A morte de Vazir-Mukhtar, 1928).

${ }^{4}$ Cf. famoso ensaio (1943) de Tyniánov sobre Gorie ot uma: TYNIÁNOV, I. Siujet "Goria ot uma". V. Kn: Puchkin i evo sovriemieniki. Moscou: $<<$ Nauka $>>, 1968$, trecho em tradução nossa, (http://az.lib.ru/t/tynjanow_j_n/text_0150.shtml,primeiro acesso em 10/03/2009). 5 Dramaturgo, crítico literário, político soviético (1875-1933). Cf. ensaio sobre Aleksandr Griboiédov (LUNATCHARSKI, Anatóli. A. S. Griboiédov v ruskoi kritike: Sbornik st. / Sost. Vstup. st. I primietch. A. M. Gordina. - M.: Goslitizdat, 1958, PP. 324-342. (http://az.lib.ru/l/lunacharskij_a_w/text_0090.shtml, primeiro acesso em 25/08/2009)
} 
se afirmar que ela soube unir uma vivacidade e uma dinâmica reais e condizentes com o período em que ela foi emitida, além de ser "um drama sobre a derrocada da inteligência humana na Rússia, sobre a inutilidade da inteligência na Rússia, sobre a dor experimentada por um representante da inteligência na Rússia"”6

Para Nikolai Ivánovitch Nadiéjdin ${ }^{7}$, crítico literário da primeira metade do século XIX, a voz não é uma comédia, "mas um vivo retrato satírico, inserido em um quadro cênico. Esse retrato apresenta a nossa boa e velha Moscou, com suas excentricidades, idiossincrasias e caprichos. (...) Trata-se de um panorama da vida em Moscou, imóvel, mas expressivo, brilhante, lindo!"8

Para Vladímir Orlov ${ }^{9}$, escritor e roteirista russo contemporâneo, a voz reflete "a realidade histórica russa de seu tempo, os primeiros dez, vinte anos do século XIX e que encontrou uma representação artística extremamente fiel e expressiva"10. O portador dessa voz "conseguiu realizar essa tarefa, porque, como pensador e artista, ele era profundamente fiel à verdade da vida,

\footnotetext{
${ }^{6}$ Lunatchárski, 1958, cit., trecho em tradução nossa.

7 Nikolai Ivánovitch Nadiéjdin (1804-1856) - professor, crítico literário - Em O mensageiro da Europa («Вестник Европы», <<Viestnik Evropy $>>$ ), a revista mais importante da época, publicou artigos de 1828 a 1830. Em resposta a ataques do crítico, Púchkin ridicularizava-o com a criação de epigramas (Índice de Notas e Referências, p. 229). Nadiéjdin escreveu um artigo (1831) sobre a primeira encenação da peça Gorie ot uma, em sua versão completa. Cf. ensaio sobre Gorie ot uma: NADIÉJDIN N. I. "Gorie ot uma", komiedia v tchetyriekh diestviakh A. Griboiedova. Sbornik st. / Sost., vstup. st. I primietch. A. M. Gordina. M.: Goslitizdat, 1958. pp. 60-69. http://feb-web.ru/feb/griboed/critics/krit/krit09.htm, acesso em 25/08/2009)

${ }^{8}$ Nadiéjdin, 1958, cit., trecho em tradução nossa.

${ }^{9}$ Vladímir Orlov (1936 - _) - escritor e roteirista russo. Cf. ensaio sobre Griboiédov: ORLOV, V. "А.С. Грибоедов". Сочинения. ГИХЛ, М.-Л., 1959. http://az.lib.ru/g/griboedow_a_s/text_0040.shtml, acesso em 26/08/2009.

${ }^{10}$ Orlov, 1959, cit., trecho em tradução nossa.
} 
porque ele estava no nível das ideias mais progressistas do século, porque compreendeu a essência e a natureza das contradições sociais mais importantes de seu tempo"11. Essa voz encarna "o mais completo e distinto retrato artístico, em nossa literatura, da vida pública na Rússia, durante a formação do movimento revolucionário dos Dezembristas" ${ }^{\prime 2}$.

Para Nikolai Polievoi ${ }^{13}$, escritor, dramaturgo e crítico teatral russo, no alto do fervor do despontar da arte no século XIX, a voz "é uma obra (...) única na língua russa e é maravilhosa para toda a literatura. Uma elevada inspiração encontra-se refletida em todas as partes dela. Mas, aparentemente, ninguém percebeu até agora a principal coisa, que significa sua maior dignidade, dá-lhe espírito nacional, fazendo-a funcionar como a obra de seu século e de seu povo. É: originalidade, modelação dos caracteres". Ele afirma que seu portador "pegou um conjunto de traços de caráter espalhados em diferentes faces $(. .$.$) , vestiu sua verdadeira forma, e Ihes deu vida,$ "com uma habilidade ainda nunca vista no cenário artístico russo", e que, na época, acredita não encontrar nem antecessores ou

\footnotetext{
${ }^{11}$ Orlov, 1959, cit. trecho em tradução nossa.

12 Orlov, 1959, op. cit., trecho em tradução nossa.

${ }^{13}$ Ksienofont Polievoi (1801-1867) - escritor, dramaturgo, crítico de teatro e de literatura, jornalista; irmão de Nikolai Polievoi, também escritor. Cf. ensaio de Polievoi sobre Gorie ot uma (1833): POLIEVOI, K. "Gorie ot uma": komiedia v tchetyriex dieistiviakh, $v$ stikhakh. Sotchiniêni Aleksandra Sergueievitcha Griboiedova. M. 1833. V.t. A. Semiena, p. 167 . in 8. (http://az.lib.ru/p/polewoj_k_a/text_0130.shtml; acesso em 13/02/2010)
} 
sucessores, pois "resgata toda a naturalidade, vitalidade e verdade da língua falada"14.

Para Óssip Zenkóvski ${ }^{15}$, escritor russo do século XIX, a voz "ocupa, em nossa literatura, por seu próprio gênero e espírito, especificamente aquele lugar do qual "As Bodas de Fígaro", a famosa comédia de Beaumarchais, apoderou-se junto aos franceses". Ele afirma que, assim como Beaumarchais, o portador da voz, "com igual talento, (...) trouxe para a cena uma compreensão política e dos hábitos das sociedades em que viviam, medindo, com um olhar altivo, a moralidade do povo de suas pátrias" ${ }^{16}$. Segundo Tyniánov ${ }^{17}$, Zenkóvski queria colocar um fim à controvérsia hipócrita que circundava a peça, pois os contrários eram certamente aqueles que se sentiam afetados por ela. Lembrando-se do texto de Zenkóvski "quem, certamente, injuria Gorie ot uma é aquele que ofende o gosto de todo o povo, um julgamento pronunciado por toda a Rússia. Esse é um livro popular: não há nenhum russo que não saiba de cor, pelo menos, dez versos da comédia"18.

14 Trechos em aspas: Polievoi, 1833, cit., tradução nossa.
15 Óssip Zenkóvski (1800-1858) - escritor russo, aqui falando acerca da primeira
edição impressa da peça. Cf. ensaio (1834) do autor sobre Gorie ot uma, primeiro
publicado na revista <<Библиотека для чтения>> (Bibliotieka dlia chtenia,
Biblioteca para leitura): ZENKÓVSKI, O.I. "Gorie ot uma", komiedia v
tchetyriekh diestviakh A. Griboiedova. Sbornik st./Sost., vstup. st. I primietch. A. M. Gordina. M.: Goslitizdat, 1958. pp. 93-94. http://az.lib.ru/s/senkowskij_o_i/text_0100.shtml, acesso em 25/08/2009.

16 Zenkóvski, 1958, cit., trecho em tradução nossa.

17 Tyniánov, 1968, cit., trecho em tradução nossa.

${ }^{18}$ Zenkóvski, 1958, op. cit., trecho em tradução nossa. 
Para Uchakov ${ }^{19}$, um dos principais componentes dessa voz, Tchátski, "não é senão como o Alceste de Molière, renascido após cento e cinquenta anos em outra província, em outra sociedade e com outras peculiaridades de misantropia, ou melhor, de filantropia excessiva, porque nem Alceste nem Tchátski podem ser acusados de ódio para com as pessoas. Pelo contrário: o desejo pelo melhor do gênero humano foi a única causa do temperamento íngreme, de sua indignação com o abuso, de suas explosões de violência contra os costumes contemporâneos(...). Sim! Tchátski não é outro, senão o bisneto de Alceste"20.

A voz tem nome: Горе от ума (Gorie ot uma). E o portador: Aleksandr Griboiédov.

A peça Gorie ot uma, escrita em versos de ritmo contagiante e sátira social mordaz, é uma das mais populares comédias russas. Seus versos, considerados antológicos, viraram provérbios do linguajar do povo. Apesar do intenso tom cômico e das tiradas de ironia profunda, o enredo carrega uma força trágica que acompanha

\footnotetext{
${ }^{19}$ Vassíli Uchakóv (1789-1838) - escritor e crítico literário russo.

20 Cf. ensaio (1830) sobre Gorie ot uma: UCHAKOV, V. A. Moskovskii bal, trietie dieistvie iz komiedii "Gorie ot uma": (Bienefis g-ji N. Repinoi) A. Griboiedova v ruskoi kritike: Sbornik st./Sost., vstup. st. I primietch. A. M. Gordina. M.: Goslitizdat, 1958. pp. 93-94, trecho em tradução nossa, http://az.lib.ru/u/ushakow_w_a/text_0030.shtml, acesso em 26/08/2009.
} 
Tchátski em seu esperado retorno à terra natal e em seu inevitável assombro frente às mudanças nas pessoas e no ambiente.

Produzida em quatro atos, contra os costumeiros cinco da tradição dramática cômica, a obra foi escrita em versos iâmbicos livres, em oposição aos clássicos alexandrinos. Sua linguagem proverbial aperfeiçoou todos os diálogos, oferecendo a cada personagem uma característica essencial e particular, entregandoIhes vida e significado arquetípico, pois eram figuras familiares a São Petersburgo e Moscou de 1820, e falavam de uma alma e de um sentimento notoriamente contemporâneos e reais.

O tema circula pela amarga verdade em que a inteligência, em uma sociedade de tolos, leva à angústia. Com as palavras do próprio Griboiédov, o enredo gira em torno do conflito entre "um homem inteligente para vinte e cinco tolos".

A fábula acompanha Tchátski, um filho pródigo que retorna à Moscou munido de diferentes ideias, e é tomado como um louco perante a sociedade. A ação desenrola-se em apenas um dia, na casa do rico proprietário de terras, Pável Afanássievitch Fámussov, em Moscou. Movimentam-se pela trama Sófia, Moltchálin, Liza, Khlióstova, Skalozúb, Zagoriétski, Repietilov, Platón Mikháilovitch, Natália Dmítrievna, a avó e a neta Khriúmina e mais uma série de figuras circunstanciais.

Aleksandr Serguéievitch Griboiédov (1795-1829) ocupou muitos anos de sua vida na criação dessa obra. Há indiretas 
evidências que indicam que a comédia começou a ser escrita já no ano de 1816. Há quem anteceda o embrião de sua ideia para 1812. Os primeiros manuscritos, ainda assim, só apareceram em 1823 e os últimos, em 1828. A versão de 1825 é uma edição fortemente censurada, e a peça, tal como é conhecida hoje, não foi publicada em vida do autor. No entanto, o texto circulava livremente em cópias manuscritas, entre os círculos literários. Foi apenas em 1862 que a peça conseguiu sua primeira e completa publicação.

Sua encenação foi proibida até 1831, época em que Griboiédov já estava morto. ${ }^{21}$ De 1831 a 1836, houve apresentações em Moscou e São Petersburgo (com grandes cortes). Nas províncias, como eram proibidas, apareceram encenações semiclandestinas. A versão íntegra da comédia não chegou ao palco até 1869.

A crítica da época - e de períodos posteriores, como visualizado nos parágrafos iniciais desta introdução - sempre consagrou qualificações grandiosas à peça, postando-a como, se não a melhor, mas como a mais disseminada e inaugural na arte dramática que destoa das heranças do século XVIII.

Para Belínski, Gógol e O Inspetor Geral eram insuperáveis e, sendo assim, passou anos desfiando pensamentos contraditórios acerca de Gorie ot uma que, em seu ensaio de 1840, dedicado à peça, devotou estar

\footnotetext{
${ }^{21}$ Griboiédov foi morto em 1829, aos 34 anos, tendo sido enviado a Teerã e atacado por um bando persa.
} 
no mais alto grau de criação poética, de numerosas pinturas individuais e caracteres originais, sem relação com o todo, pintada artisticamente com um pincel forte, de mestre, a mão firme, a qual, caso a trema, não terá sido por fraqueza, mas por uma indignação fervente, nobre, que uma jovem alma ainda não conseguiu dominar. A esse respeito, Gorie ot uma, em seu todo, é uma espécie de construção disforme, insignificante em seu propósito, tal como um galpão, mas uma construção feita de fino mármore da ilha de Paros, com decorações de ouro, maravilhosas esculturas, colunas graciosas. A esse respeito, Gorie ot uma permanece em um mesmo espaço imensurável e infinito, acima das comédias de Fonvízin, assim como abaixo de $O$ Inspetor Geral'22.

A obra é considerada um divisor de águas, marcando o fim de uma época na história da comédia e o início de outra, que atingiria seu ápice em O Inspetor Geral (1836), de Nikolai Gógol.

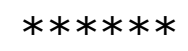

Após um panorama geral sobre a importância da obra Gorie ot uma, de Aleksandr Griboiédov, para a sociedade e cultura russa, chegamos ao ponto fulcral da origem do presente trabalho, principalmente, porque não conhecemos, até agora, a obra em questão, senão, talvez, em esparsas menções em alguns artigos e livros teóricos. Para o Brasil, o nome de Griboiédov e Gorie ot uma soa distante, talvez da mesma forma com que soe nosso Camões e o

22 BELÍNSKI, V. G. "Gorie ot uma". Komiedia $v$ 4-kh dieistviakh, $v$ stikhakh. Sotchiniêni. A. C. Griboiedova, 1839. http://az.lib.ru/b/belinskij_w_g/text_0020.shtml, trecho em tradução nossa, primeiro acesso em 20/04/2007. 
crucial Os Lusíadas aos ouvidos russos. A comparação à obra Os Lusíadas não é gratuita, pois almeja, talvez, alcançar uma síntese de base da língua portuguesa que a obra de Camões representa, comparada à força inaugural que a obra de Griboiédov oferta à literatura russa.

Não há um único acadêmico brasileiro que não conheça Os Lusíadas, assim como acontece também a Gorie ot uma, no universo russo. No entanto, por que uma obra de tamanha envergadura não encontra vez no universo estrangeiro de quem estuda a literatura russa? Sabemos que Púchkin, e a sua importância clássica, Dostoiévski e Tolstói, em seus grandes romances, Tchékhov, em peças inesquecíveis, encontram espaço no mundo acadêmico brasileiro. Mas por que não encontra espaço uma obra tão importante como Gorie ot uma? A primeira resposta - e, certamente, a resposta que liderará todas as outras - fixa-se na complexidade da linguagem em que a obra foi escrita.

Até hoje, nunca houve, no Brasil, um trabalho direcionado a traduzir a obra e a espera de quem se propõe a fazê-lo tem caráter de impossibilidade, visto a estrutura complexa e outras especificidades que transformam Gorie ot uma em um enigma.

Não se trata apenas de uma comédia versificada, como vaudevilles e pequenas encenações que já figuravam no século XVIII, mas sim, de uma das maiores obras, cuja força está muito além de qualquer transposição, de qualquer tentativa de transposição a outros 
idiomas. Há que transpormos a síntese de uma estrutura linguística, o universo social e de fundação de uma cultura: quando falamos na transposição de uma obra como Gorie ot uma, devemos pensar em todas essas questões, não como meros alicerces para as revelações da mensagem original ao receptor. Aqui, na obra de Griboiédov, o trabalho de análise linguística, social e cultural, ganha conotações mais profundas, pois falamos aqui de um modelo, de um estandarte histórico conhecido, notadamente, pela riqueza de sua linguagem.

A riqueza da linguagem de uma obra está intrinsecamente aliada ao âmbito cultural, de tradição de seu povo. É a expressão direta e subjetiva (que, mesmo subjetiva, carrega a voz de uma cultura; cultura esta que formou o repertório do autor) do artista em relação ao mundo a sua volta. É expressão direta de uma ideia que, na mensagem emitida, depara-se, constantemente, com a ideia inicial, exata, pertencente a um código específico. Poder-se-ia dizer que, para o russo, não há Gorie ot uma que não seja a expressa no idioma russo. Isso porque, até hoje, as traduções, em todo o mundo, não conseguiram alçar a musicalidade, o ritmo, a grandeza dos provérbios. Ao lermos uma tradução de Gorie ot uma ao inglês, ao francês, ao espanhol, ao italiano, não conseguimos compreender, ao certo, por que essa obra é tão importante e tão crucial para a cultura russa. Nós, leitores estrangeiros, por meio desses idiomas, alcançamos a trama, posicionamos sua estrutura no universo do neoclassicismo russo, mas, em verdade, não entendemos o valor, o 
valor que pressupõe a riqueza da linguagem e que faz com que os russos exultem de satisfação por terem, em seu cânone literário, a presença de Gorie ot uma. Será que a ideia que se quer transmitir em mensagem só funciona como verdadeiramente autêntica, em um único código específico, a língua russa?

Aqui, entramos em questões muito decisivas ao ato da tradução (e que aqui, dada a complexidade da linguagem, ganha tom particular). Francis Henrik Aubert, em sua obra As (in) fidelidades da tradução, remete-nos à questão da fidelidade de uma tradução, principalmente àquilo que parece inacessível. E, assim, chama-nos para uma tarefa obstinada e sistemática de "atinar - ainda que em vão - com o que o autor original "quis dizer" e de encontrar meios de expressão para essa intenção comunicativa suposta (...) A fidelidade na tradução caracteriza-se, pois, pela conjuminação de um certo grau de diversidade com um certo grau de identidade; ela será, não por deficiência intrínseca ou fortuita, mas por definição, por essencialidade, um compromisso (instável) entre essas duas tendências antagônicas, atingindo a sua plenitude nesse compromisso e nessa instabilidade"23.

A partir desse excerto, podemos pensar - já que não encontramos modelos de um compromisso eficaz na tradução de Gorie ot uma, pelo mundo todo -, certamente, que a instabilidade reina nessa tarefa obstinada e o compromisso, por vezes, parece

\footnotetext{
${ }^{23}$ AUBERT, Francis - As in(fidelidades) da tradução: servidões e autonomia do tradutor/ Campinas,SP: Editora da UNICAMP,1993, p. 77.
} 
antes tarefa impossível ${ }^{24}$. No entanto, na tentativa de esmiuçarmos essa impossibilidade, deparamo-nos com uma conjunção da ideia contraditória que jaz na união entre o "compromisso" e o "impossível". O "compromisso" serve como um acordo entre as partes, e o "impossível" como cessão desse "compromisso", posto que "impossível".

Acerca da questão, podemos relembrar as palavras de Haroldo de Campos sobre a tradução de alguns excertos de Evguiéni Oniéguin:

No plano do seu mero conteúdo anedótico, despojado de sua forma significante, a obra-prima de Púchkin parece trivial e previsível em seu argumento romanesco quase elementar, baseado nas alternativas do amorcorrespondido e da paixão sem horizonte, que a virtude conjugal torna impossível. Chega-se a dar razão, num primeiro pensamento, ao juízo depreciativo de Flaubert manifestado a Turguéniev: "Il est plat, votre poète"."125

Ao mencionarmos esse trecho de Campos, aproximamo-nos da questão discutida aqui e que também se relaciona à forma significante da obra. As traduções à obra de Griboiédov, como têm sido feitas, não acabam por revelar apenas o caráter trivial da trama? Estaria a grandeza da obra, principalmente, na forma significante?

No caso de Campos, com o trabalho da trans-criação, recorrese a uma radicalização em vários dos parâmetros de estrutura de uma obra. Para o poeta e tradutor, não há outra possibilidade para

\footnotetext{
24"Expondo à prova da prática a teoria, o que se vê, em primeiro lugar, é que a traduzibilidade de qualquer texto depende das semelhanças ou diferenças de estrutura entre a língua-fonte e a língua-meta;"(CAMPOS, Geir. O que é tradução?, São Paulo: Editora Brasiliense, 1986, p. 65)

25 CAMPOS, Haroldo - "Púchkin: A poesia da Gramática" (in. Caderno de
} literatura e cultura russa, n. 1, São Paulo: Ateliê Editorial, 2004, p.62) 
Oniéguin. E para Gorie ot uma? Será possível uma transposição da obra sem o universo da trans-criação?

Sem compreender ao certo como desfiar tais questões, alcançamos uma resolução polêmica: sabemos da importância da obra Gorie ot uma ao universo cultural russo, no entanto, sabemos das tentativas em transpô-la a outros idiomas (e que, ao olhar dos que a leem como nativos, na língua de origem, são ineficazes). No entanto, é essa infidelidade proveniente de um casamento que não existe por definição? É válido traduzir uma obra que não encontra parâmetros para uma tradução? Devemos tentar a tradução de uma obra como Gorie ot uma, dadas as especificações problemáticas apresentadas acima?

Uma resposta a essas questões é a tarefa primordial do presente trabalho, tentando, assim, afastar uma impossibilidade, e crendo apenas no compromisso que, ao final, poderá ser impossível, mas, na trajetória, principalmente compromisso. Essa resposta será uma apresentação da obra Gorie ot uma, de Aleksandr Griboiédov, ao público brasileiro.

Adentraremos o universo de criação de Gorie ot uma, as bases de sua existência, dos fundamentos que complementaram a formação do autor, fazendo-o detentor de sua realização. Logo após, esmiuçaremos o conteúdo, buscaremos paralelos, deparando, por vezes, com o olhar crítico que a recebeu e a recebe, desde a época 
de seu surgimento. Ao final, abriremos caminho para que essa trajetória de compromisso seja, em uma primeira vez, testada.

O compromisso não acaba por aqui; é, antes, uma olhar aproximativo para a união de dois universos distintos: uma primeira tentativa de tradução ao português da obra grandiosa de Aleksandr Griboiédov. É apenas germe que vislumbra, no futuro, frondosas possibilidades e que reconhece que, todo grande trabalho busca, em primeiro, fundamentar-se, conhecer, absorver, com vagar e afinco, uma atmosfera da qual não se conhece ainda o organismo e nem o ar. 


\section{PARTE I}

Tradução de Gorie ot uma, Aleksandr Griboiédov 


\section{Dilemas da tradução de Gorie ot uma, de Aleksandr Griboiédov}

Como já dito anteriormente, a peça é considerada uma das grandes obras do Teatro Russo e isso é estranho aos nossos ouvidos, porque poucas foram as tentativas em traduzi-la para outros idiomas. Grande parte dessa carência em traduções está na composição complexa em que os versos se estruturam no original. O ritmo contagiante se deve, principalmente, à escolha minuciosa de termos que, juntos, são muito musicais. Sabe-se que Griboiédov foi criado em um ambiente que prezava muito a música e ele mesmo é um compositor (com algumas obras de conhecimento na Rússia). Mesmo sem conhecer o idioma a fundo, é possível ler os versos da peça e perceber como a musicalidade dos versos agiliza as palavras e provoca uma cadência animada e vivente.

Muito dessa agilidade provém dos iambos, a conjunção entre sílaba breve e sílaba longa, funcionando, assim, como uma conjunção de ondas que vão perpassando os versos livres. Aurora Bernardini relembra-nos a constatação de B. Unbegaum, em Russian Versification, onde a "variabilidade do acento cria o ritmo de um verso russo e the confere sua individualidade. Cabe a cada poeta encontrar, nas molduras de um dado metro, o ritmo mais apropriado às circunstâncias. À parte a questão do léxico e da eufonia, é lá que 
reside em grande parte a arte da versificação russa"26. Tomando como ponto de partida, aos desafios de uma tradução da obra Gorie ot uma, começamos a analisar de que forma poderíamos reproduzir, em português, o tipo de sonoridade provocada pela versificação em iambos.

O título da peça expressa a ideia que persiste por toda a obra, em questão do caráter sintético da peça: Горе от ума (Gorie ot uma). São diversas as tentativas em buscar uma tradução adequada para a concisão e sintetização vistas no idioma russo. Infortúnio do talento, A desgraça de ter engenho, A desgraça de ter espírito, são algumas das versões que aparecem em obras que transpuseram o título para o português ${ }^{27}$. Em inglês, a força do título foi proximamente alcançada em Woe from wit. Em espanhol, El ingenio produce penas e Es una locura ser sensato, recuperam a comicidade satírica da obra.

Para Simon Karlinsky - em sua obra Russian Drama -, a dificuldade no título é tão grande que, mesmo para as crianças russas, torna-se lenta a compreensão. O termo Гope em russo quer dizer: angústia, desgraça. $Y_{M}$ é a inteligência, razão, intelecto. Literalmente, a tradução pede por um A desgraça/angústia da inteligência. O professor Boris Schnaiderman sugeriu $A$ desgraça de ter espírito. Esse título, novamente segundo Karlinsky, provém das formas inglesas e francesa: The misfortune of being clever e Le

\footnotetext{
${ }^{26}$ UNBEGAUM, B.; (Apud BERNARDINI, Aurora F. "Puchkin e o começo da literatura russa" (in. Caderno de Literatura Russa, n.1, São Paulo: Ateliê Editorial, 2004, p. 34)

${ }^{27}$ A peça, na íntegra, ainda não foi traduzida para o português.
} 
Malheur d'avoir d'esprit. No entanto, esta tradução provém do título da peça de Oscar Wilde, The importance of being earnest.

A solução, portanto, mais próxima ao título original, e pertencente a uma língua latina é o italiano Che disgrazia... l'ingegno! A versão para o título, em italiano, é fiel ao conteúdo inerente ao título e, sendo assim, seguimos seu caminho. Decidimos, portanto, por $A$ inteligência, que desgraça!, posto que as palavras, 'engenho' e 'espírito', soam datadas ao leitor da atualidade.

Outro grande entrave na transposição ao português são os famosos provérbios lançados por Griboiédov e que hoje são parte intrínseca da cultura russa. É esse tipo de dificuldade que encontramos por toda a obra. Os versos concisos - obtidos pela própria síntese em que a língua russa é constituída - transformam-se em longos versos nas línguas latinas e, assim, podem perder a musicalidade, que é um dos grandes atrativos da peça.

E é isso que sentimos ao ler os versos em ritmo sequencial mesmo sem conhecer o significado, é possível perceber a tonalidade proverbial. E como transpô-los ao português? Recriando o ambiente de sua significação. Tentou-se manter, na tradução, o conteúdo de cada verso e, por vezes, buscou-se um ritmo com uso de rimas.

Com o intuito de proporcionar ao leitor melhor compreensão do conteúdo, serão comentados, nas notas de rodapé, alguns fatos mencionados pelas personagens de Griboiédov, os costumes inerentes à época, e alguns pontos acerca das palavras. 


\section{Tradução}

\begin{tabular}{|c|c|}
\hline A inteligência, que desgraça! - & Горе от ума- \\
\hline A.C.Griboiedov. & А.С.Грибоедов. \\
\hline Comédia em quatro atos, em versos. & Комедия в четьрех действиях в стихах \\
\hline Personagens: & Действующие: \\
\hline Pável Afanássievitch Fámussov, & Павел Афанасьевич Фамусов, \\
\hline chefe de um posto estatal. & управляющий в казенном месте. \\
\hline Sófia Pávlovna, sua filha. & Софья Павловна, его дочь. \\
\hline Lízanka, uma criada. & Лизанька, служанка. \\
\hline Aleksei Stiepánovitch Moltchálin, & Алексей Степанович Молчалин, \\
\hline secretário de Fámussov. Ele mora em sua & секретарь Фамусова, живущий у него \\
\hline 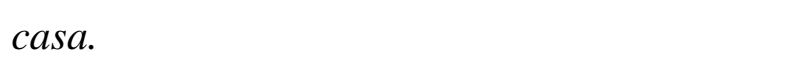 & в доме. \\
\hline Aleksandr Andréievitch Tchátski. & Александр Андреевич Чацкий. \\
\hline Coronel Skalozúb, Serguei Serguéievitch. & Полковник Скалозуб, Сергей Сергеевич. \\
\hline Natália Dmítrievna, uma jovem dama, & Наталья Дмитриевна, молодая дама, \\
\hline Platón Mikháilovitch, seu marido, - & Платон Михаилович, муж еe, - \\
\hline Os Góritch. & Горичи. \\
\hline Príncipe Tugoúkhovski e & Князь Тугоуховский и \\
\hline Princesa, sua esposa, com seis filhas. & Княгиня, жена его, с шестью дочерями. \\
\hline Condessa avó, Condessa neta, as & Графиня бабушка, Графиня внучка, - \\
\hline Khriúmina. & Хрюмины. \\
\hline Antón Antónovitch Zagoriétski. & Антон Антонович Загорецкий. \\
\hline A velha Khlióstova, cunhada de Fámussov. & Старуха Хлестова, свояченица Фамусова. \\
\hline Senhor N. & Г.N. \\
\hline Senhor D. & Г.D. \\
\hline Repietilov. & Репетилов. \\
\hline Pietrúchka $e$ alguns criados-personagens. & Петрушка и несколько говорящих слуг. \\
\hline Uma multidão de convidados de quaisquer & Множество гостей всякого разбора \\
\hline categorias e seus criados, na hora da partida. & и их лакеев при разъезде. \\
\hline Empregados de Fámussov. A ação se passa & Официанты Фамусова. Действие в Москве в \\
\hline em Moscou, na casa de Fámussov. & доме Фамусова. \\
\hline
\end{tabular}




\begin{tabular}{|c|c|}
\hline ATO I & ДЕЙСТВИЕ І \\
\hline Cena 1 & Явление 1 \\
\hline $\begin{array}{l}\text { Uma sala de estar. Há um grande relógio à } \\
\text { direita do quarto de Sófia, de onde se ouve o } \\
\text { som de um piano e de uma flauta. O som logo } \\
\text { emudece. No meio do aposento, Lizanka } \\
\text { dorme, debruçada na poltrona. É manhã, o dia } \\
\text { mal desponta. }\end{array}$ & $\begin{array}{l}\text { Гостиная, в ней большие часы, справа дверь } \\
\text { в спальню Софии, откудова слышно } \\
\text { фортопияно с флейтою, которые потом } \\
\text { умолкают. Лизанька середи комнаты спит, } \\
\text { свесившись с кресел. Утро, чуть день } \\
\text { брежжитсяю. }\end{array}$ \\
\hline $\begin{array}{l}\text { Lizanka } \\
\text { (de repente acorda, levanta-se da poltrona, } \\
\text { olha ao redor) }\end{array}$ & $\begin{array}{l}\text { Лизанька } \\
\text { (вдруг просылается, встает с кресел, } \\
\text { оглядывается) }\end{array}$ \\
\hline Amanhece!... Ah! Mas que noite ligeira! & Светает!.. Ах! как скоро ночь минула! \\
\hline $\begin{array}{l}\text { Ontem: posso dormir? - pedido negado. } \\
\text { Esperemos o amigo: um olho deitando, o } \\
\text { outro acordado, }\end{array}$ & $\begin{array}{l}\text { Вчера просилась спать - отказ, } \\
\text { "Ждем друга". - Нужен глаз да глаз, }\end{array}$ \\
\hline Não vá dormir para não cair da cadeira. & Не спи, покудова не скатишься со стула. \\
\hline $\begin{array}{l}\text { Agora que cochilei assim de tal maneira, } \\
\text { Já é dia!... Devo alertá-los... } \\
\text { (bate à porta de Sófia) }\end{array}$ & $\begin{array}{l}\text { Теперь вот только что вздремнула, } \\
\text { Уж день!.. сказать им... } \\
\text { (Стучится к Софии.) }\end{array}$ \\
\hline Senhores, & Господа, \\
\hline Ei! Sófia Pavlovna, a desgraça. & Эй! Софья Павловна, беда. \\
\hline Noite adentro e a conversa não acabou. & Зашла беседа ваша за ночь; \\
\hline Estão surdos? Aleksei Stiepánitch! Ô! & Вы глухи? - Алексей Степаныч! \\
\hline $\begin{array}{l}\text { Meus senhores! - E eles não têm medo! } \\
\text { (afasta-se da porta) }\end{array}$ & $\begin{array}{l}\text { Сударыня!..- И страх их не берет! } \\
\text { (Отходит от дверей.) }\end{array}$ \\
\hline Vamos, convidado indesejado, & Ну, гость неприглашенный, \\
\hline Vai que o paizinho esteja ao lado! & Быть может, батюшка войдет! \\
\hline $\begin{array}{l}\text { É nisso que dá servir a uma moça apaixonada! } \\
\text { (de novo, à porta) }\end{array}$ & $\begin{array}{l}\text { Прошу служить у барышни влюбленной! } \\
\text { (Опять к дверям) }\end{array}$ \\
\hline
\end{tabular}




\begin{tabular}{|c|c|}
\hline Vamos, separem-se. É manhã & Да расходитесь. Утро. \\
\hline - Que é senhora? ${ }^{\mathrm{a}}$ & - Что-с? \\
\hline (A voz de Sófia) & (Голос Софии) \\
\hline Que horas são? & Который час? \\
\hline Lízanka & Лизанька \\
\hline Todos já se levantaram em casa. & Все в доме поднялось. \\
\hline Sófia ${ }^{b}$ & София \\
\hline (de seu quarto) & (из своей комнаты) \\
\hline Que horas são? & Который час? \\
\hline Lizanka & Лизанька \\
\hline Sete, oito, nove. & Седьмой, осьмой, девятый. \\
\hline Sófia & София \\
\hline (de lá mesmo) & (оттууда же) \\
\hline É mentira. & Неправда. \\
\hline Lizanka & Лизанька \\
\hline (fora da porta) & (прочь от дверей) \\
\hline Ah! Amur ${ }^{c}$ maldito! & Ах! амур проклятый! \\
\hline Estão ouvindo e se fazem de desentendidos! & И слышат, не хотят понять, \\
\hline Devo abrir as cortinas? & Ну что бы ставни им отнять? \\
\hline $\begin{array}{l}\text { Eu vou mudar os ponteiros }{ }^{\mathrm{d}} \text {, sei que vão me } \\
\text { xingar, }\end{array}$ & Переведу часы, хоть знаю: будет гонка, \\
\hline Mas vou fazê-lo tocar. & Заставлю их играть. \\
\hline (sobe na cadeira, adia o ponteiro, o relógio & (Лезет на стул, передвигает стрелку, часы \\
\hline bate e soa a campainha.) & бьют и играют.) \\
\hline Cena 2 & Явление 2 \\
\hline Liza e Fámussov & Лиза и Фамусов. \\
\hline
\end{tabular}




\section{Liza}

Ah! Senhor!

\section{Fámussov $^{\mathrm{e}}$}

Senhor, sim.

(faz parar a música do relógio)

Pois veja só, que danadinha!

Estar por trás disso, quem mais poderia?

Ora ouve-se uma flauta, ora talvez um piano,

Não é cedo demais para Sofia??

\section{Liza}

Não, senhor, eu... Foi só um descuido...

\section{Fámussov}

Aí atrás, aí é que está o descuido,

Veja, Exatamente de propósito!

(achega-se a ela, brincando)

Ai! Espertinha, que garota travessa!

\section{Liza}

O senhor é que é travesso, não tem vergonha!

\section{Fámussov}

É discreta, mas na cachola,

Só futilidade e caraminholas.

\section{Liza}

Ah, me deixe, seu desmiolado,

Pense bem, o senhor é um velho...

\section{Fámussov}

\section{Лиза}

Ax! барин!

\section{Фамусов}

Барин, да.

(Останавливает часовую музыку)

Ведь экая шалунья ты, девчонка.

Не мог придумать я, что это за беда!

То флейта слышится, то будто фортопьяно;

Для Софьи слишком было б рано??

\section{Лиза}

Нет, сударь, я... лишь невзначай...

\section{Фамусов}

Вот то-то невзначай, за вами примечай;

Так, верно, с умыслом.

(Жмется к ней и заигрывает)

Ой! зелье, баловница.

\section{Лиза}

Вы баловник, к лицу ль вам эти лица!

\section{Фамусов}

Скромна, а ничего кроме

Проказ и ветру на уме.

Лиза

Пустите, ветреники сами,

Опомнитесь, вы старики...

\section{Фамусов}




\begin{tabular}{|c|c|}
\hline Nem tanto. & Почти. \\
\hline Liza & Лиза \\
\hline E se alguém chegar, aonde nós vamos? & Ну, кто придет, куда мы с вами? \\
\hline Fámussov & Фамусов \\
\hline Quem é que viria? & Кому сюда придти? \\
\hline Pois Sófia não dorme? & Ведь Софья спит? \\
\hline Liza & Лиза \\
\hline Só agora pegou no sono. & Сейчас започивала. \\
\hline Fámussov & Фамусов \\
\hline Só agora! E à noite? & Сейчас! А ночь? \\
\hline Liza & Лиза \\
\hline Leu a noite toda. & Ночь целую читала. \\
\hline Fámussov & Фамусов \\
\hline Veja que caprichos aparecem! & Вишь, прихоти какие завелись! \\
\hline Liza & Лиза \\
\hline $\begin{array}{l}\text { Lendo em voz alta, trancada, tudo em } \\
\text { francês. }{ }^{\mathrm{f}}\end{array}$ & Все по-французски, вслух, читает запершись. \\
\hline Fámussov & Фамусов \\
\hline $\begin{array}{l}\text { Vá dizer a ela que os olhos estragam sem mais } \\
\text { serventia, }\end{array}$ & Скажи-ка, что глаза ей портить не годится, \\
\hline Pois da leitura não se tira grande valia: & И в чтеньи прок-от не велик: \\
\hline Com os livros franceses o sono dela não vem, & Ей сна нет от французских книг, \\
\hline $\begin{array}{l}\text { Mas, para mim, com os livros russos se dorme } \\
\text { muito e bem. }\end{array}$ & А мне от русских больно спится. \\
\hline Liza & Лиза \\
\hline
\end{tabular}




\begin{tabular}{|c|c|}
\hline Assim que ela levantar, eu digo isso, & Что встанет, доложусь, \\
\hline Trate então de sair; temo que vá acordá-la. & Извольте же идти, разбудите, боюсь. \\
\hline Fámussov & Фамусов \\
\hline Como acordar? O próprio relógio tem corda, & Чего будить? Сама часы заводишь, \\
\hline Por todo o bairro ribomba uma sinfonia. & На весь квартал симфонию гремишь. \\
\hline Liza & Лиза \\
\hline (o mais alto possível) & (как можно громче) \\
\hline Chega, basta disso, senhor. & Да полноте-с! \\
\hline Fámussov & Фамусов \\
\hline (tapando a boca dela) & (зажимает ей рот) \\
\hline Ora, como você berra! & Помилуй, как кричишь. \\
\hline Ficou louca? & С ума ты сходишь? \\
\hline Liza & Лиза \\
\hline Temo que os outros nos vejam... & Боюсь, чтобы не вышло из того... \\
\hline Fámussov & Фамусов \\
\hline O quê? & Чего? \\
\hline Liza & Лиза \\
\hline $\begin{array}{l}\text { Vamos, está na hora, o senhor não é mais um } \\
\text { garoto; }\end{array}$ & Пора, сударь, вам знать, вы не ребенок; \\
\hline O sono matinal de uma moça é tão delicado; & У девушек сон утренний так тонок; \\
\hline O menor rangido da porta, o menor sopro: & Чуть дверью скрипнешь, чуть шепнешь: \\
\hline Tudo se ouve... & Все слышат... \\
\hline Fámussov & Фамусов \\
\hline E você mente sobre tudo. & Все ты лжешь. \\
\hline A voz de Sófia & Голос Софии \\
\hline Ei, Liza! & Эй, Лиза! \\
\hline
\end{tabular}




\section{Fámussov}

(apressadamente)

Psiu!

(vai de mansinho para fora do quarto, sem fazer barulho.)

\section{Liza}

(sozinha)

Saiu!... Ah! Afaste-se dos senhores;

Com eles, a desgraça mora ao lado -

Poupe-nos de todas as tristezas

Que vem dos senhores: do ódio e também do amor.

Cena 3

(Liza, Sófia com o lampião; atrás dela, Moltchálin)

\section{Sófia}

Que se passou contigo, Liza?

Quanto barulho!

Liza

Claro, está difícil de se despedirem?

Trancados até o raiar, e parece ainda pouco?

\section{Sófia}

Ah! Amanhece de fato!

(apaga o lampião)

E com a luz, a tristeza. Como são rápidas as noites!
Фамусов

(торопливо)

$\mathrm{Tc} !$

(Крадется вон из комнаты на ијьпочках.)

\section{Лиза}

(одна)

Ушел... Ах! от господ подалей;

У них беды себе на всякий час готовь,

Минуй нас пуще всех печалей

И барский гнев, и барская любовь.

Явление 3

Лиза, София со свечкою, за ней

\section{Молчалин.}

\section{София}

Что, Лиза, на тебя напало?

Шумишь...

\section{Лиза}

Конечно, вам расстаться тяжело?

До света запершись, и кажется все мало?

\section{София}

Ах, в самом деле рассвело!

(Тушит свечу.)

И свет и грусть. Как быстры ночи! 


\section{Liza}

A senhorita está tão triste e não percebe, mas não tenho mais forças para vê-la assim.

Seu pai veio aqui, fiquei paralisada;

Tentei escapar, mas, na frente dele, sobre o que mentir, não lembrei, histórias para contar, eu nem sei!

E você? Senhor, pode se despedir e zarpar.

Vá, seu coração não está no lugar;

Olhe para o relógio, vamos, para janela:

O povo se amontoa há muito pelas ruas;

Em casa todos a bater, a caminhar, a varrer e tocam a andar.

\section{Sófia}

Não se nota o tempo quando se é feliz ${ }^{\mathrm{g}}$.

\section{Liza}

Se não nota o tempo, isso é contigo,

Mas a responsabilidade disso, é claro, fica comigo.

\section{Sófia}

(a Moltchálin)

Vá. Suportaremos ainda um dia todo de tédio.

\section{Liza}

Então está bem, vamos, vamos: agora soltem as mãos.

(separa-os; Moltchálin, à porta,

dá com Fámussov)

\section{Лиза}

Тужите, знай, со стороны нет мочи,

Сюда ваш батюшка зашел, я обмерла;

Вертелась перед ним, не помню что врала;

Ну что же стали вы? поклон, сударь,отвесьте.

Подите, сердце не на месте;

Смотрите на часы, взгляните-ка в окно:

Валит народ по улицам давно;

А в доме стук, ходьба, метут и убирают.

\section{София}

Счастливые часов не наблюдают.

Лиза

Не наблюдайте, ваша власть;

А что в ответ за вас, конечно, мне попасть.

\section{София}

(Молчалину)

Идите; целый день еще потерпим скуку.

\section{Лиза}

Бог с вами-с; прочь возьмите руку.

(Разводит их, Молчалин в дверях

сталкивается с Фамусовым.) 


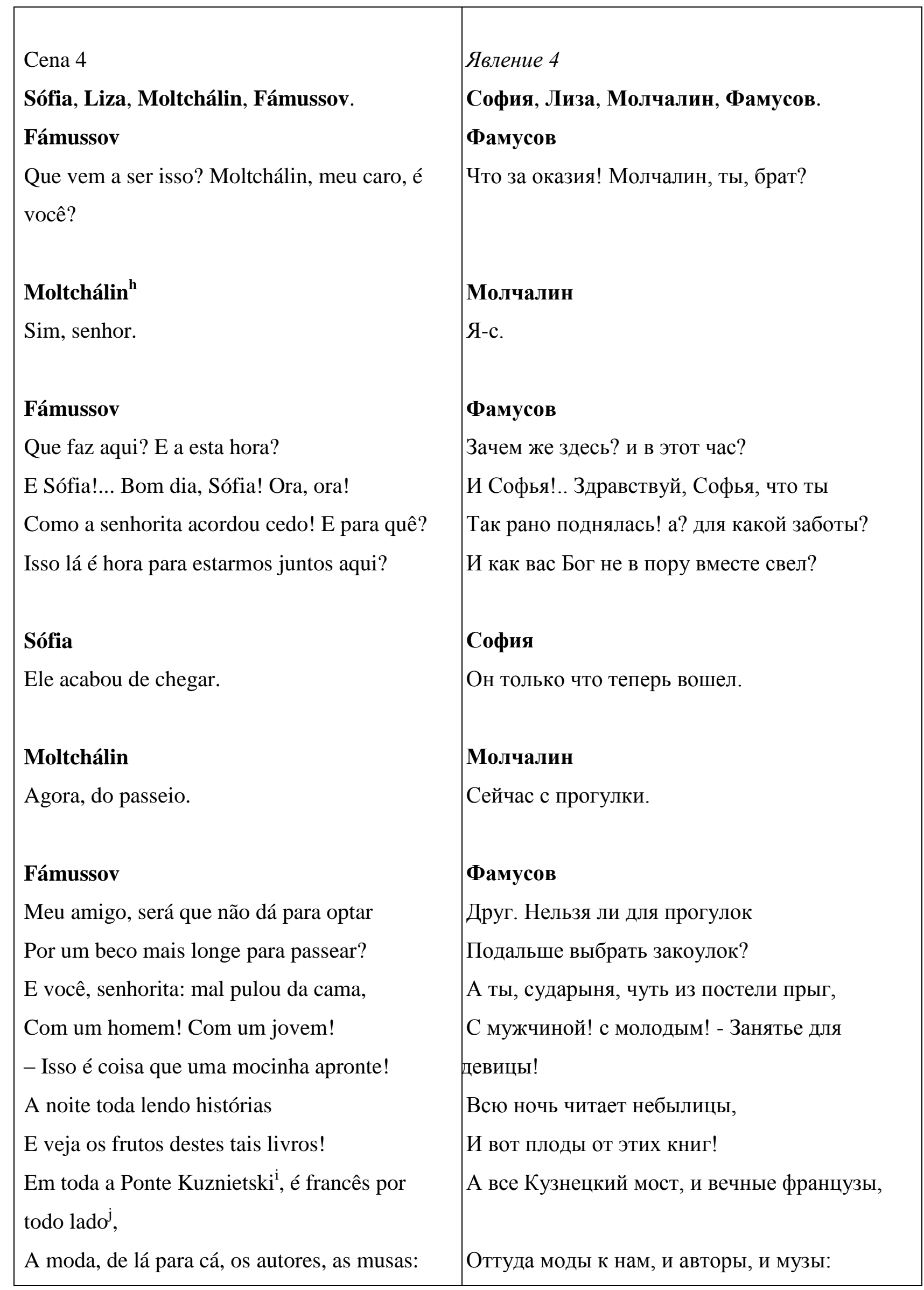


O mal em nosso bolso e perto do coração.

E quando será que o criador nos poupará

De seus chapéus! Toucas! Grampos! E

alfinetes!

Das livrarias e confeitarias?

\section{Sófia}

Paizinho, perdão, minha cabeça está girando!

Eu mal posso respirar, de tanto espanto;

O senhor entrou correndo tão agilmente,

Que eu me confundi.

\section{Fámussov}

Ora, me livre disso aí,

Logo eu entrei correndo!

Eu incomodei! Eu espantei!

Eu, Sófia Pávlovna, estou muito abalado, o

dia todo, sem descanso,

Apresso-me como se fosse um desvairado.

Por dever, ocupado pelo serviço,

Sempre me importunam, para tudo precisam de $\operatorname{mim} !$

Mas será que eu esperava mais coisas para me extenuar assim? Como ser enganado...

\section{Sófia}

(entre lágrimas)

Por quem, paizinho?

\section{Fámussov}

Todos me acusam,

Dizem que eu sempre repreendo à toa.

Não chore, é sério, me ouça:
Губители карманов и сердец!

Когда избавит нас творец

От шляпок их! чепцов! и шпилек! и булавок!

И книжных и бисквитных лавок!.

\section{София}

Позвольте, батюшка, кружится голова;

Я от испуги дух перевожу едва;

Изволили вбежать вы так проворно,

Смешалась я...

\section{Фамусов}

Благодарю покорно,

Я скоро к ним вбежал!

Я помешал! я испужал!

Я, Софья Павловна, расстроен сам, день целый,

Нет отдыха, мечусь как словно угорелый.

По должности, по службе хлопотня,

Тот пристает, другой, всем дело до меня!

Но ждал ли новых я хлопот? чтоб был обманут...

\section{София}

(сквозь слезы)

Кем, батюшка?

\section{Фамусов}

Вот попрекать мне станут,

Что без толку всегда журю.

Не плачь, я дело говорю: 
Pois já não me preocupei

Com a sua educação! E desde o berço!

Sua mãe morreu: tive de contratar

Madame ${ }^{k}$ Rose como segunda mãe.

A velhinha de ouro punha-se a vigiá-la:

Sábia, calma, raras vezes lhe punia.

Mas há algo que não lhe serve de honraria:

Por míseros cinquenta rublos ao ano

Deixou-se atrair para outro canto.

Mas isso não está nos poderes de uma governanta.

Não é necessário outro modelo,

Quando aos olhos há o exemplo de um pai.

Olhe para mim: não me gabo pelo meu porte,

Mas chego à velhice bem disposto e forte.

Livre e viúvo, sou senhor de mim,

Sou conhecido por uma conduta de monge!

\section{Liza}

Eu me atrevo, senhor...

\section{Fámussov}

\section{Cale-se!}

Século terrível! Por onde começar, sabe-se lá! Todos se tornam mais sábios antes do tempo.

E as filhas são ainda pior que os outros, isso, aqueles outros, que se têm em alto apreço!

Estou farto de ouvir isso!

Arranjamos então um professor domiciliar e lhe é pago por vez,

Para que às nossas filhas ensinem de tudo, de tudo - Das danças! Das canções! Da ternura! Da inspiração!
Уж об твоем ли не радели

Об воспитаньи! с колыбели!

Мать умерла: умел я принанять

В мадам Розье вторую мать.

Старушку-золото в надзор к тебе приставил:

Умна была, нрав тихий, редких правил.

Одно не к чести служит ей:

За лишних в год пятьсот рублей

Сманить себя другими допустила.

Да не в мадаме сила.

Не надобно иного образца,

Когда в глазах пример отца.

Смотри ты на меня: не хвастаю сложеньем;

Однако бодр и свеж, и дожил до седин,

Свободен, вдов, себе я господин...

Монашеским известен поведеньем!..

Лиза

Осмелюсь я, сударь...

\section{Фамусов}

\section{Молчать!}

Ужасный век! Не знаешь, что начать!

Все умудрились не по летам.

А пуще дочери, да сами добряки.

Дались нам эти языки!

Берем же побродяг, и в дом и по билетам,

Чтоб наших дочерей всему учить, всему -

И танцам! и пенью! и нежностям! и вздохам! 
Como se preparássemos esposas para palhaços ${ }^{1}$.

E você, visitante, que há? Aqui, senhor, e para quê?

Sem berço, foi levado e aconchegado em minha família,

Dei-lhe um cargo de assessor ${ }^{\mathrm{m}}$ e o tomei como secretário,

Foi levado a Moscou graças a tudo que lhe fiz,

Viraria um mendigo em Tvier ${ }^{\mathrm{n}}$, se não fosse por mim.

\section{Sófia}

Não, eu não quero explicar a sua ira.

O que se pode fazer, ele vive aqui em casa! Quis entrar em um quarto, parou em outro.

\section{Fámussov}

Veio parar ou quis parar?

E juntos, para quê? Não pode ser por acaso.

\section{Sófia}

Mas em todo caso:

Há pouco o senhor esteve com Liza aqui, Sua voz me confundiu demais, E, então, me lancei para cá num zás...

\section{Fámussov}

Vai descarregar toda a confusão em mim. A minha voz causou-lhes um transtorno, é assim?!
Как будто в жены их готовим скоморохам.

Ты, посетитель, что? ты здесь, сударь, к чему?

Безродного пригрел и ввел в мое семейство,

Дал чин асессора и взял в секретари;

В Москву переведен через мое содейство;

И будь не я, коптел бы ты в Твери.

\section{София}

Я гнева вашего никак не растолкую.

Он в доме здесь живет, великая напасть!

Шел в комнату, попал в другую.

\section{Фамусов}

Попал или хотел попасть?

Да вместе вы зачем? Нельзя, чтобы случайно.

\section{София}

Вот в чем, однако, случай весь:

Как давиче вы с Лизой были здесь, Перепугал меня ваш голос чрезвычайно, И бросилась сюда я со всех ног...

\section{Фамусов}

Пожалуй, на меня всю суматоху сложит.

Не в пору голос мой наделал им тревог! 


\section{Sófia}

Uma coisinha me perturbou por conta de um sonho angustiante:

Vou lhe contar o sonho: o senhor há de entender mais adiante.

\section{Fámussov}

Que espécie de história?

Sófia

Posso lhe contar?

\section{Fámussov}

Pois vamos.

(senta-se.)

Sófia

Permita-me... Veja...

Primeiro eu vi um prado florido;

Eu procurava uma erva qualquer,

Na realidade, não me lembro.

De repente, um homem gentil,

Um daqueles que vemos como se há séculos o conhecêssemos,

Surgiu aqui comigo; insinuante e sábio,

Mas tímido... O senhor sabe, quem nasce na pobreza...

\section{Fámussov}

Ah, minha filha, não me venha com essa!

Quem é pobre, mas você não é.

\section{София}

По смутном сне безделица тревожит;

Сказать вам сон: поймете вы тогда.

\section{Фамусов}

Что за история?

\section{София}

Вам рассказать?

\section{Фамусов}

Ну да.

(Садится.)

\section{София}

Позвольте... видите ль... сначала

Цветистый луг; и я искала

Траву

Какую-то, не вспомню наяву.

Вдруг милый человек, один из тех, кого мы

Увидим - будто век знакомы,

Явился тут со мной; и вкрадчив, и умен, Но робок... Знаете, кто в бедности рожден...

\section{Фамусов}

Ах! матушка, не довершай удара!

Кто беден, тот тебе не пара. 


\section{Sófia}

Logo, tudo desapareceu: o prado e o céu.

Nós estamos em um quarto escuro. No fim, um milagre abriu-se do chão, e o senhor estava lá,

Pálido como um morto e de cabelos em pé! Aqui, a porta escancarou com um trovão.

Alguma coisa, que não era gente e nem bicho, Nos separou, e atormentava aquele que estava sentado comigo.

Ele era como se fosse o mais querido de todos os tesouros,

Quis ir a ele - o senhor o levava consigo:

Acompanhava-nos um gemido, um lamento,

Um choro, um silvo horrível! ${ }^{\circ}$

Depois disso, ele gritou!

Acordei - alguém falava...

Era a voz do senhor; por que, pensei eu, tão cedo?

Corro para cá - e encontro a ambos.

\section{Fámussov}

Sim, é um sonho ruim ${ }^{\mathrm{p}}$. Como vejo, Aqui há tudo, se não fosse uma invenção:

Diabo e amor, flores e paixão,

Mas e você, meu senhor?

\section{Moltchálin}

Eu ouvi a voz do senhor.

\section{Fámussov}

Ora, mas que engraçado!

\section{София}

Потом пропало все: луга и небеса. -

Мы в темной комнате. Для довершенья чуда

Раскрылся пол - и вы оттуда,

Бледны, как смерть, и дыбом волоса!

Тут с громом распахнули двери

Какие-то не люди и не звери,

Нас врознь - и мучили сидевшего со мной.

Он будто мне дороже всех сокровищ,

Хочу к нему - вы тащите с собой:

Нас провожают стон, рев, хохот, свист чудовищ!

Он вслед кричит!.. -

Проснулась. - Кто-то говорит, -

Ваш голос был; что, думаю, так рано?

Бегу сюда - и вас обоих нахожу.

\section{Фамусов}

Да, дурен сон, как погляжу.

Тут все есть, коли нет обмана:

И черти и любовь, и страхи и цветы.

Ну, сударь мой, а ты?

\section{Молчалин}

Я слышал голос ваш.

\section{Фамусов}

Забавно. 


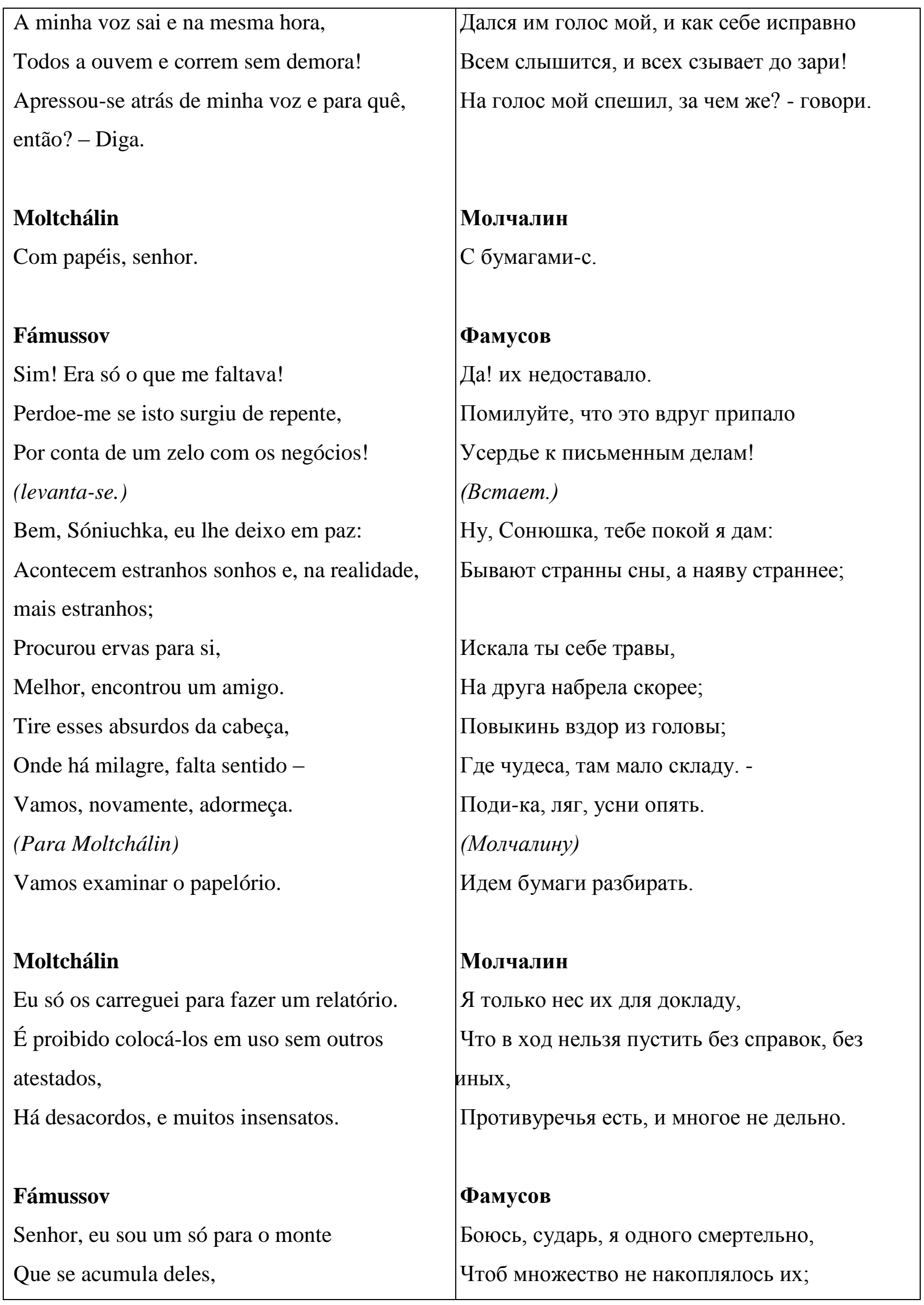




\begin{tabular}{|c|c|}
\hline Uma hora eles hão de se encontrar; & Дай волю вам, оно бы и засело; \\
\hline Aos negócios ou não, & А у меня, что дело, что не дело, \\
\hline É meu costume: & Обычай мой такой: \\
\hline Uma vez assinados, estão fora de questão. & Подписано, так с плеч долой. \\
\hline (sai com Moltchálin, à porta, deixa-o passar & (Уходит с Молчалиным, в дверях пропускает \\
\hline na frente) & его вперед.) \\
\hline Cena 5 & Явление 5 \\
\hline Sófia, Liza & София, Лиза. \\
\hline Liza & Лиза \\
\hline Que festa! E que distração! & Ну вот у праздника! ну вот вам и потеха! \\
\hline Mas agora isso já não é divertido não: & Однако нет, теперь уж не до смеха; \\
\hline Os olhos vendados, a alma pasma. & В глазах темно, и замерла душа; \\
\hline $\begin{array}{l}\text { O pecado não é uma desgraça, mas os } \\
\text { rumores o são... }\end{array}$ & Грех не беда, молва не хороша. \\
\hline Sófia & София \\
\hline $\begin{array}{l}\text { Que são para mim os rumores? Quem quiser } \\
\text { que assim julgue. }\end{array}$ & Что мне молва? Кто хочет, так и судит, \\
\hline E o paizinho forçará a refletir & Да батюшка задуматься принудит: \\
\hline Rabugento, persistente e veloz, & Брюзглив, неугомонен, скор, \\
\hline Tal como sempre e desde tanto... & Таков всегда, а с этих пор... \\
\hline Você pode imaginar... & Ты можешь посудить... \\
\hline Liza & Лиза \\
\hline Eu não julgo pela história, senhora; & Сужу-с не по рассказам; \\
\hline Ele a trancará, melhor seria se fosse comigo. & Запрет он вас, - добро еще со мной; \\
\hline Pois Deus me perdoe, eu, Moltchálin, & А то, помилуй Бог, как разом \\
\hline E todo o resto vamos é ouvir um "Fora!" & Меня, Молчалина и всех с двора долой. \\
\hline Sófia & София \\
\hline Imagine como a felicidade é voluntariosa! & Подумаешь, как счастье своенравно! \\
\hline
\end{tabular}


Acontece o pior e se sai impune;

Quando se está triste, nada passa pela cabeça,

Esquece-se da música, e o tempo, suave, a

caminhar;

Como se o destino estivesse nos guardado;

Sem dúvida ou desagrado.

Enquanto que a desgraça espera em um canto, para atacar.

\section{Liza}

Aí é que está a desgraça:

a senhorita nunca quis saber das minhas tolas opiniões.

Mas para que melhor profeta?

Eu repito de novo: Vantagem nesse seu amor?

Nem por todos os séculos e séculos ${ }^{\mathrm{q}}$ !

Como todo moscovita, seu pai é assim:

Ele quer um genro com condecorações e patentes,

Mas, entre nós, nem todos com condecorações são ricos;

Bem, quer dizer aquele

que tem dinheiro para viver bem e para dar bailes;

Veja, por exemplo, o coronel Skalozúb:

Um ricaço que quer chegar a general.

\section{Sófia}

Como é encantador!

E me alegra muito escutar sobre o fronte, sobre as fileiras;

Em sua vida, ele nunca pronunciou qualquer esperteza -

Tanto faz ficar com ele ou me afogar.
Бывает хуже, с рук сойдет;

Когда ж печальное ничто на ум нейдет,

Забылись музыкой, и время шло так плавно;

Судьба нас будто берегла;

Ни беспокойства, ни сомненья...

А горе ждет из-за угла.

\section{Лиза}

Вот то-то-с, моего вы глупого сужденья

Не жалуете никогда:

Ан вот беда.

На что вам лучшего пророка?

Твердила я: в любви не будет в этой прока Ни во веки веков.

Как все московские, ваш батюшка таков:

Желал бы зятя он с звездами, да с чинами,

А при звездах не все богаты, между нами;

Ну, разумеется к тому 6

И деньги, чтоб пожить, чтоб мог давать он балы;

Вот, например, полковник Скалозуб:

И золотой мешок, и метит в генералы.

\section{София}

Куда как мил! и весело мне страх

Выслушивать о фрунте и рядах;

Он слова умного не выговорил сроду, -

Мне все равно, что за него, что в воду. 


\section{Liza}

Sim, senhora, ele é, vamos dizer, um falador,

Mas não é lá muito entendedor;

Mas seja militar, civil,

O mais alegre, espirituoso e sutil,

É Aleksandr Andréiitch Tchátski!

Mas não há por que se atazanar, não;

Há muito que ele não volta,

Mas lembre-se...

\section{Sófia}

Lembrar-me de quê? Ele só

sabe rir dos outros;

Ele tagarela, brinca, eu me divirto;

Mas eu posso me divertir com qualquer um.

\section{Liza}

E só isso? Será possível? Era lágrima por todo o lado.

Eu me lembro, coitado, quando se separaram.

- Por que chora, senhor? Vamos, sorria!

E ele, em resposta: << Liza, meu choro não é por acaso:

Quem sabe o que encontrarei, quando voltar?

E quanto, talvez, eu vou perder!>>

E em três anos! O coitadinho devia saber... ${ }^{\mathrm{r}}$

\section{Sófia}

Escute aqui, eu não lhe dou essa liberdade.

Talvez eu tenha agido de maneira muito insensata,

E sei, reconheço a culpa; mas onde e com

\section{Лиза}

Да-с, так сказать речист, а больно не хитер;

Но будь военный, будь он статский, Кто так чувствителен, и весел, и остер, Как Александр Андреич Чацкий!

Не для того, чтоб вас смутить;

Давно прошло, не воротить,

А помнится...

\section{София}

Что помнится? Он славно

Пересмеять умеет всех;

Болтает, шутит, мне забавно;

Делить со всяким можно смех.

\section{Лиза}

И только? будто бы? - Слезами обливался,

Я помню, бедный он, как с вами расставался.

-Что, сударь, плачете? живите-ка смеясь...

А он в ответ: "Недаром, Лиза, плачу:

Кому известно, что найду я воротясь?

И сколько, может быть, утрачу!"

Бедняжка будто знал, что года через три...

\section{София}

Послушай, вольности ты лишней не бери.

Я очень ветрено, быть может, поступила,

И знаю, и винюсь; но где же изменила? 
quem falhei, para que me censure por infidelidade?

Sim, com Tchátski, é verdade, nós fomos educados, crescemos;

Tínhamos o costume de estar todos os dias juntos, inseparáveis,

Unidos desde a infância pela amizade; mas depois,

Ele se mudou, aborrecia-se conosco

E raramente visitava nossa casa;

Depois, novamente se fingiu apaixonado,

Exigente e magoado!!

Espirituoso, esperto, eloquente,

Era particularmente feliz com sua gente ${ }^{\mathrm{s}}$,

E tinha a si próprio em alta conta...

O desejo de viajar caiu sobre ele.

Ah! Se ele amasse quem quer que fosse,

Para que sair por aí e tão longe?

\section{Liza}

Por onde ele anda? Em que canto foi parar?

Dizem que foi para uma estância de águas ${ }^{\mathrm{t}}$, foi se tratar,

Não por doença, ao que parece, de tédio - de bom grado.

\section{Sófia}

E deve estar feliz por lá, onde as pessoas são mais ridículas.

Quem eu amo não é assim:

Moltchálin está pronto para esquecer-se de si em prol dos outros,

É inimigo da insolência, está sempre
Кому? чтоб укорять неверностью могли.

Да, с Чацким, правда, мы воспитаны, росли:

Привычка вместе быть день каждый разлучно Связала детскою нас дружбой; но потом

Он съехал, уж у нас ему казалось скучно, И редко посещал наш дом;

Потом опять прикинулся влюбленным, Взыскательным и огорченным!!.

Остер, умен, красноречив,

В друзьях особенно счастлив, Вот об себе задумал он высоко...

Охота странствовать напала на него, Ах! если любит кто кого, Зачем ума искать и ездить так далеко?

\section{Лиза}

Где носится? в каких краях?

Лечился, говорят, на кислых он водах,

Не от болезни, чай, от скуки, - повольнее.

\section{София}

И, верно, счастлив там, где люди посмешнее.

Кого люблю я, не таков:

Молчалин, за других себя забыть готов,

Враг дерзости, - всегда застенчиво, несмело 


\begin{tabular}{|c|c|}
\hline acanhado, tímido..." & \\
\hline Passar uma noite toda assim com alguém! & Ночь целую с кем можно так провесть! \\
\hline $\begin{array}{l}\text { Nós nos sentamos, e lá fora há muito já } \\
\text { amanhecia, que você acha? Com que nos } \\
\text { ocupávamos? }\end{array}$ & $\begin{array}{l}\text { Сидим, а на дворе давно уж побелело, } \\
\text { Как думаешь? чем заняты? }\end{array}$ \\
\hline Liza & Лиза \\
\hline Só Deus sabe, & Бог весть, \\
\hline Senhora, que é que eu tenho a ver com isso? & Сударыня, мое ли это дело? \\
\hline Sófia & София \\
\hline Ele pegou minha mão e a apertou ao coração, & Возьмет он руку, к сердцу жмет, \\
\hline $\begin{array}{l}\text { Deu um suspiro que veio das profundezas da } \\
\text { alma, }\end{array}$ & Из глубины души вздохнет, \\
\hline $\begin{array}{l}\text { Passou a noite toda assim, sem uma palavra } \\
\text { ousada. }\end{array}$ & Ни слова вольного, и так вся ночь проходит, \\
\hline $\begin{array}{l}\text { As mãos dadas, sem levantar os olhos para } \\
\text { mim, }\end{array}$ & Рука с рукой, и глаз с меня не сводит. - \\
\hline Você está rindo! Será possível! & Смеешься! можно ли! чем повод подала \\
\hline $\begin{array}{l}\text { Que motivos eu lhe dei para uma gargalhada } \\
\text { como essa! }\end{array}$ & Тебе я к хохоту такому! \\
\hline Liza & Лиза \\
\hline Eu, senhora? É que me lembrei de sua tia, & Мне-с?.. ваша тетушка на ум теперь пришла, \\
\hline De como o jovem francês fugiu da casa dela. & Как молодой француз сбежал у ней из дому. \\
\hline Meu bem! Ela quis disfarçar a dor, & Голубушка! хотела схоронить \\
\hline Mas não sabia como: & Свою досаду, не сумела: \\
\hline Esqueceu-se de escurecer os cabelos, & Забыла волосы чернить \\
\hline E em três dias, eles ficaram brancos. & И через три дни поседела. \\
\hline (continua a gargalhar.) & (Продолжает хохотать.) \\
\hline $\begin{array}{l}\text { Sófia } \\
\text { (com desgosto) }\end{array}$ & $\begin{array}{l}\text { София } \\
\text { (с огорчением) }\end{array}$ \\
\hline
\end{tabular}




\begin{tabular}{|c|c|}
\hline $\begin{array}{l}\text { É assim que vão começar a falar de mim logo } \\
\text { mais. }\end{array}$ & Вот так же обо мне потом заговорят. \\
\hline Liza & Лиза \\
\hline Perdoe-me mesmo, de verdade, por Deus, & Простите, право, как Бог свят, \\
\hline Eu queria que esse riso tolo & Хотела я, чтоб этот смех дурацкий \\
\hline Alegrasse ainda que um pouco. & Вас несколько развеселить помог. \\
\hline Cena 6 & Явление 6 \\
\hline Sófia, Liza, Criado, atrás dele, Tchátski. & София, Лиза, слуга, за ним Чацкий. \\
\hline Criado & Слуга \\
\hline $\begin{array}{l}\text { Aleksandr Andréiitch Tchátski. } \\
\text { (sai.) }\end{array}$ & $\begin{array}{l}\text { К вам Александр Андреич Чацкий. } \\
(\text { Уходит.) }\end{array}$ \\
\hline Cena 7 & Явление 7 \\
\hline Sófia, Liza, Tchátski. ${ }^{\mathrm{v}}$ & София, Лиза, Чацкий. \\
\hline Tchátski $^{\mathrm{w}}$ & Чацкий \\
\hline $\begin{array}{l}\text { Mal amanhece e já está de pé! E eu estou aos } \\
\text { seus pés. }{ }^{\mathrm{x}}\end{array}$ & Чуть свет уж на ногах! и я у ваших ног. \\
\hline (beija sua mão com entusiasmo) & (С жаром ичелует руку.) \\
\hline $\begin{array}{l}\text { Vamos, me beije! Então, não me esperava? } \\
\text { Diga! }\end{array}$ & Ну поцелуйте же, не ждали? говорите! \\
\hline $\begin{array}{l}\text { Então, está feliz? Não? Olhe para mim. } \\
\text { Surpresa? Pois só isso? Que jeito de me } \\
\text { receber! }\end{array}$ & $\begin{array}{l}\text { Что ж, ради? Нет? В лицо мне посмотрите. } \\
\text { Удивлены? и только? вот прием! }\end{array}$ \\
\hline Como se não houvessem passado semanas, & Как будто не прошло недели; \\
\hline Como se estivéssemos juntos ontem. & Как будто бы вчера вдвоем \\
\hline Nós não podemos aborrecer um ao outro. & Мы мочи нет друг другу надоели; \\
\hline Nenhum sinal de amor! Como você está bem! & Ни на волос любви! куда как хороши! \\
\hline $\begin{array}{l}\text { E em todo esse tempo, não posso me } \\
\text { recuperar sozinho, }\end{array}$ & И между тем, не вспомнюсь, без души, \\
\hline
\end{tabular}


Não preguei o olho por quarenta e cinco horas, nem por um segundo;

Corri por mais de setecentas verstas ${ }^{\mathrm{y}}-$ vento e tormentas;

Eu perdi tudo e por vezes caí -

E veja a minha recompensa!

\section{Sófia}

Ah, Tchátski, eu estou muito feliz em revê-lo!

\section{Tchátski}

Está feliz? Isso vem em boa hora.

Mas, sinceramente, quem pode se alegrar assim?

Quanto a isso não tenho dúvida.

Exaustos os criados, derreados os cavalos, Eu achei que fosse valer para mim.

\section{Liza}

Veja só, senhor, se estivesse atrás da porta, Vale-me Deus, nem cinco minutos atrás, Veria como nós nos lembrávamos do senhor aqui.

Senhora, confirme isso.

\section{Sófia}

Sempre, não apenas agora -

Não pode me recriminar.

Quem passa como um relâmpago, abre a porta,

De passagem, por acaso, de terras estrangeiras, de longe -

Mesmo que seja um marinheiro, eu encho de
Я сорок пять часов, глаз мигом не прищуря,

Верст больше седьмисот пронесся, - ветер, буря;

И растерялся весь, и падал сколько раз -

И вот за подвиги награда!

\section{София}

Ax! Чацкий, я вам очень рада.

\section{Чацкий}

Вы ради? в добрый час.

Однако искренно кто ж радуется эдак?

Мне кажется, так напоследок

Людей и лошадей знобя,

Я только тешил сам себя.

Лиза

Вот, сударь, если бы вы были за дверями, Ей-Богу, нет пяти минут, Как поминали вас мы тут.

Сударыня, скажите сами.

\section{София}

Всегда, не только что теперь. -

Не можете мне сделать вы упрека.

Кто промелькнет, отворит дверь,

Проездом, случаем, из чужа, из далека -

С вопросом я, хоть будь моряк: 
perguntas:

Não teria avistado a carruagem de Tchátski?

\section{Tchátski}

Admitamos que seja verdade.

Bem aventurado é aquele que crê!

Ah! Meu Deus! Eis me aqui de novo!

Em Moscou!E contigo! E como a encontro!

Para onde foi aquele tempo? Para onde foi aquela época inocente,

Quando, por vezes, na noite longa,

Aparecíamos e desaparecíamos aqui e ali,

Brincávamos e desordenávamos as mesas e cadeiras,

Enquanto o seu paizinho jogava piquêt $\hat{e}^{\mathrm{z}}$ com a governanta;

E nós, em nosso cantinho escuro e, me parece, $\log$ aqui!

Lembra? Nós estremecíamos com um rangido da mesa, da porta...

\section{Sófia}

Criancice!

\section{Tchátski}

Sim, mas agora a senhorita floresceu,

Admiravelmente, aos dezessete anos,

De modo incomparável, e sabe disso.

Não olha para o mundo porque ele lhe parece simples demais.

Não estaria apaixonada? Responda-me sem pensar,

Chega de ficar desconcertada.
Не повстречал ли где в почтовой вас карете?

\section{Чацкий}

Положимте, что так.

Блажен, кто верует, тепло ему на свете! -

$\mathrm{Ax!} \mathrm{Боже} \mathrm{мой!} \mathrm{ужли} \mathrm{я} \mathrm{здесь} \mathrm{опять,}$

В Москве! у вас! да как же вас узнать!

Где время то? где возраст тот невинный,

Когда, бывало, в вечер длинный

Мы с вами явимся, исчезнем тут и там,

Играем и шумим по стульям и столам.

А тут ваш батюшка с мадамой, за пикетом;

Мы в темном уголке, и кажется, что в этом!

Вы помните? вздрогнем, что скрипнет столик, дверь...

\section{София}

Ребячество!

\section{Чацкий}

Да-с, а теперь,

В седьмнадцать лет вы расцвели прелестно,

Неподражаемо, и это вам известно,

И потому скромны, не смотрите на свет.

Не влюблены ли вы? прошу мне дать ответ,

Без думы, полноте смущаться. 


\section{Sófia}

Pois o que me desconcerta

São perguntas rápidas e olhares curiosos...

\section{Tchátski}

Perdoe-me. Se não for contigo, com o que devo me surpreender?

Que há de novo aqui em Moscou?

Ontem teve um baile, amanhã haverá dois. Um propôs casamento e conseguiu; mas outro, se deu mal.

As mesmas conversas, os mesmos versos escritos no caderninho ${ }^{\text {aa }}$.

\section{Sófia}

Contra Moscou. O que significa conhecer o mundo!

Onde, então, é melhor?

\section{Tchátski}

Onde não estamos.

Mas e seu pai? De todo o clube Inglês ${ }^{\text {bb }}$, Ele é o membro mais velho, fiel até a morte. Será que seu tiozinho chegou a este século? E aquele turco ou grego,

Aquele moreninho, de perninhas finas, Não sei como se chama,

Que se metia em qualquer lugar:

Aqui e ali, nas salas de jantar e de estar? E quanto àqueles três indivíduos ordinários Que com meio século de idade tentam se passar por jovens?

\section{София}

Да хоть кого смутят

Вопросы быстрые и любопытный взгляд..

\section{Чацкий}

Помилуйте, не вам, чему же удивляться?

Что нового покажет мне Москва?

Вчера был бал, а завтра будет два.

Тот сватался - успел, а тот дал промах.

Все тот же толк, и те ж стихи в альбомах.

\section{София}

Гоненье на Москву. Что значит видеть свет!

Где ж лучше?

\section{Чацкий}

Где нас нет.

Ну что ваш батюшка? все Английского клоба Старинный, верный член до гроба?

Ваш дядюшка отпрыгал ли свой век?

А этот, как его, он турок или грек?

Тот черномазенький, на ножках журавлиных, Не знаю, как его зовут,

Куда ни сунься: тут как тут,

В столовых и в гостиных.

А трое из бульварных лиц,

Которые с полвека молодятся? 


\begin{tabular}{|c|c|}
\hline $\begin{array}{l}\text { Há milhares deles por aqui e com a ajuda de } \\
\text { irmãzinhas }\end{array}$ & Родных мильон у них, и с помощью сестриц \\
\hline Multiplicam-se por toda a Europa. & Со всей Европой породнятся. \\
\hline E o nosso anjinho? Nosso tesouro? & А наше солнышко? наш клад? \\
\hline Estava escrito na testa: Teatro e Baile; & На лбу написано: Театр и Маскерад; \\
\hline A casa colorida de verde como um arvoredo, & Дом зеленью раскрашен в виде рощи, \\
\hline $\begin{array}{l}\text { Ele era o mais obeso, enquanto os seus artistas } \\
\text { eram secos. }\end{array}$ & Сам толст, его артисты тощи. \\
\hline $\begin{array}{l}\text { Em um baile, lembra-se, nós dois } \\
\text { descobrimos, }\end{array}$ & На бале, помните, открыли мы вдвоем \\
\hline $\begin{array}{l}\text { Por trás dos biombos, em um dos quartos } \\
\text { secretos, }\end{array}$ & За ширмами, в одной из комнат посекретней, \\
\hline $\begin{array}{l}\text { Um homem escondido que estalava como um } \\
\text { rouxinol, }\end{array}$ & Был спрятан человек и щелкал соловьем, \\
\hline Um cantor de verão quando ainda era inverno. & Певец зимой погоды летней. \\
\hline $\begin{array}{l}\text { E aquele tísico, seu parente: inimigo dos } \\
\text { livros, }\end{array}$ & А тот чахоточный, родня вам, книгам враг, \\
\hline Que se estabeleceu no comitê científico, & В ученый комитет который поселился \\
\hline E que, aos gritos, exigia um juramento & И с криком требовал присяг, \\
\hline $\begin{array}{l}\text { Para que ninguém aprendesse ou soubesse } \\
\text { nada a partir da arte de ler e escrever? }\end{array}$ & Чтоб грамоте никто не знал и не учился? \\
\hline $\begin{array}{l}\text { Vê-los novamente é, para mim, um juízo do } \\
\text { destino! }\end{array}$ & Опять увидеть их мне суждено судьбой! \\
\hline $\begin{array}{l}\text { Viver com eles não passa de um fardo, mas } \\
\text { quem atira a primeira pedra? }\end{array}$ & $\begin{array}{l}\text { Жить с ними надоест, и в ком не сыщешь } \\
\text { пятен? }\end{array}$ \\
\hline $\begin{array}{l}\text { Quando corremos o mundo e voltamos para } \\
\text { casa, a fumaça da pátria nos parece doce e } \\
\text { agradável! }^{\text {cc }}\end{array}$ & $\begin{array}{l}\text { Когда ж постранствуешь, воротишься домой, } \\
\text { И дым Отечества нам сладок и приятен! }\end{array}$ \\
\hline Sófia & София \\
\hline Eu o levaria à minha titia, & Вот вас бы с тетушкою свесть, \\
\hline $\begin{array}{l}\text { Para que pudesse saber sobre todos os que } \\
\text { conhecia. }\end{array}$ & Чтоб всех знакомых перечесть. \\
\hline
\end{tabular}




\section{Tchástki}

E sua titia? Toda donzela, deusa Minerva?

A dama de honra de Catarina Primeira ${ }^{\mathrm{dd}}$ ?

Ainda atrai pupilas e cachorrinhos para sua casa?

Ah! Passemos à educação.

Por que agora, como também outrora,

Andam em busca de reunir uma multidão

De tutores, em números exorbitantes

E a preços insignificantes?

A ciência não está longe, de forma alguma;

Na Rússia, sob pena de enorme multa,

Ordenam que reconheçamos qualquer um

Como professor de História e Geografia!

O nosso mentor, lembra-se, seu gorro, seu roupão

E o dedo indicador... Todos sinais de erudição.

Como inquietava nossas mentes acanhadas,

Como, tão cedo, nos habituamos a acreditar

Que sem alemães não há salvação!

E Guillaume, o francês, cabeça-de-vento?

Ele ainda não se casou?

\section{Sófia}

Com quem se casaria?

\section{Tchátski}

Seja com qualquer princesa,

Talvez, com Pulkhéria Andréievna?

\section{Чацкий}

А тетушка? все девушкой, Минервой?

Все фрейлиной * Екатерины Первой?

Воспитанниц и мосек полон дом?

Ax! к воспитанью перейдем.

Что нынче, так же, как издревле,

Хлопочут набирать учителей полки,

Числом поболее, ценою подешевле?

Не то, чтобы в науке далеки;

В России, под великим штрафом,

Нам каждого признать велят

Историком и географом!

Наш ментор, помните колпак его, халат,

Перст указательный, все признаки ученья

Как наши робкие тревожили умы, Как с ранних пор привыкли верить мы, Что нам без немцев нет спасенья!

А Гильоме, француз, подбитый ветерком?

Он не женат еще?

\section{София}

На ком?

\section{Чацкий}

Хоть на какой-нибудь княгине

Пульхерии Андревне, например? 


\begin{tabular}{|c|c|}
\hline Um dançarino! Vejam só se é possível! & Танцмейстер! можно ли! \\
\hline Tchátski & Чацкий \\
\hline Pois bem, ele é um cavalheiro! & Что ж, он и кавалер. \\
\hline Exijam que tenhamos nome e grau, & От нас потребуют с именьем быть и в чине, \\
\hline $\begin{array}{l}\text { Embora Guillaume }{ }^{\mathrm{ee}} ! . . . \text { Agora é moda aqui, } \\
\text { tal como }\end{array}$ & А Гильоме!.. - Здесь нынче тон каков \\
\hline Nos congressos, em público & На съездах, на больших, по праздникам \\
\hline e em quermesses, & приходским? \\
\hline Prevalecer ainda a mistura de línguas: & Господствует еще смешенье языков: \\
\hline Francês com nijni-novgorodês? ${ }^{\mathrm{ff}}$ & Французского с нижегородским? \\
\hline Sófia & София \\
\hline Mistura de línguas? & Смесь языков? \\
\hline Tchátski & Чацкий \\
\hline Sim, ao menos duas, é proibido ter só uma. & Да, двух, без этого нельзя ж. \\
\hline Sófia & София \\
\hline $\begin{array}{l}\text { E deveria fazer-se delas uma, para que fique } \\
\text { complicada como a sua. }\end{array}$ & Но мудрено из них один скроить, как ваш. \\
\hline Tchátski & Чацкий \\
\hline Pelo menos é natural ${ }^{\mathrm{gg}}$. & По крайней мере не надутый. \\
\hline Mais essa agora! Eu aproveito esses minutos, & Вот новости! - я пользуюсь минутой, \\
\hline Animado por estar com você, & Свиданьем с вами оживлен, \\
\hline $\begin{array}{l}\text { Por isso estou falante }{ }^{\text {hh }} \text {; será que deu tempo } \\
\text { de eu ficar mais tolo que Moltchálin? Onde } \\
\text { ele está, a propósito? }\end{array}$ & $\begin{array}{l}\text { И говорлив; а разве нет времен, } \\
\text { Что я Молчалина глупее? Где он, кстати? }\end{array}$ \\
\hline $\begin{array}{l}\text { Será que ele ainda não rompeu o selo do } \\
\text { silêncio? }\end{array}$ & Еще ли не сломил безмолвия печати? \\
\hline $\begin{array}{l}\text { Por vezes, quando avistava uma nova } \\
\text { cançãozinha, }\end{array}$ & Бывало песенок где новеньких тетрадь \\
\hline Em algum caderno, vinha nos importunar: & Увидит, пристает: пожалуйте списать. \\
\hline
\end{tabular}




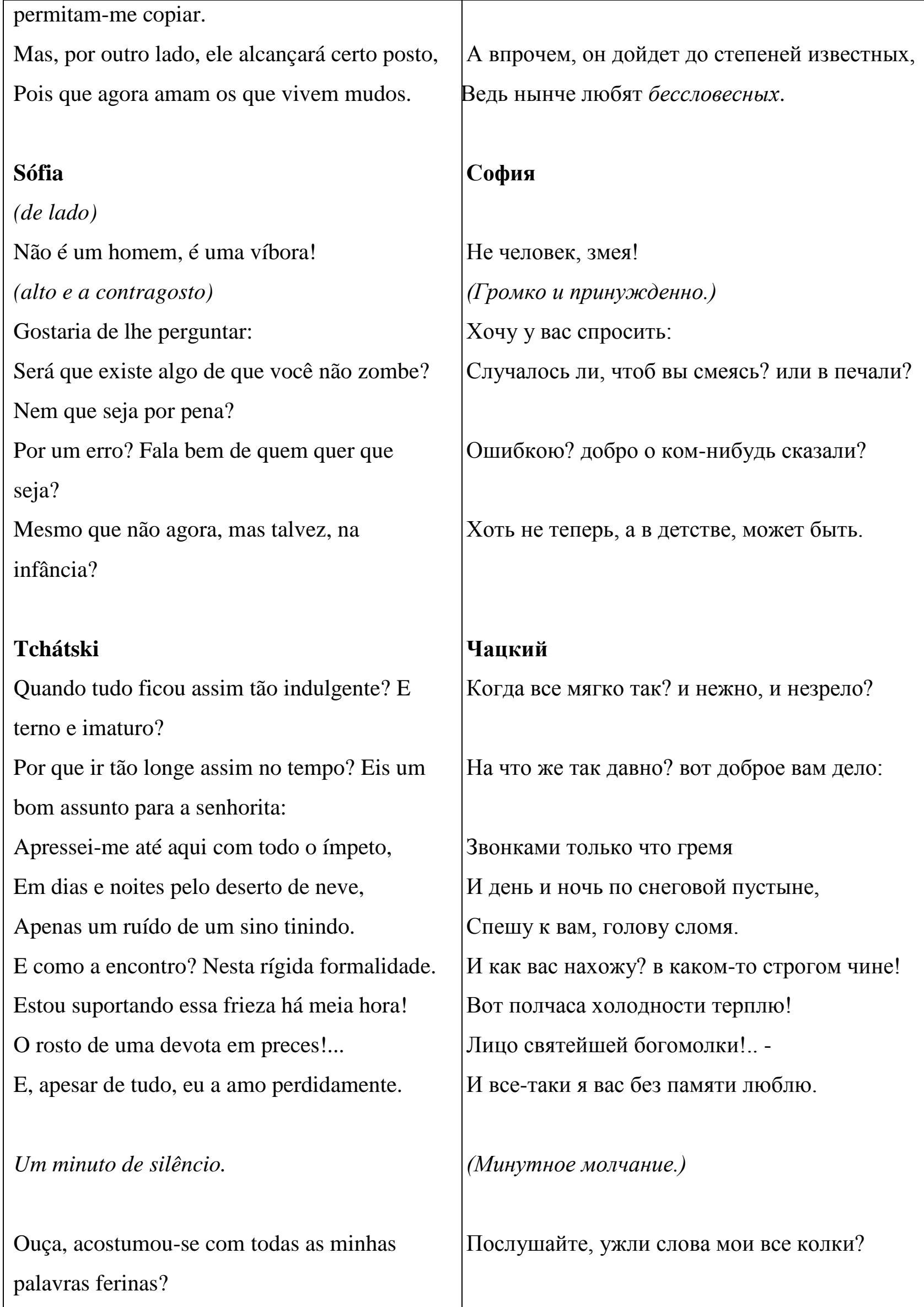




\begin{tabular}{|c|c|}
\hline $\begin{array}{l}\text { Elas tendem a fazer mal a quem quer que } \\
\text { seja? }\end{array}$ & И клонятся к чьему-нибудь вреду? \\
\hline $\begin{array}{l}\text { Mas se for assim: coração e mente estão em } \\
\text { desarmonia. }\end{array}$ & Но если так: ум с сердцем не в ладу. \\
\hline Eu zombo dos outros por brincadeira. & Я в чудаках иному чуду \\
\hline Uma vez eu rio, depois eu esqueço; & Раз посмеюсь, потом забуду: \\
\hline $\begin{array}{l}\text { Se você me mandar ao fogo, eu irei como se } \\
\text { estivesse indo almoçar. }\end{array}$ & Велите ж мне в огонь: пойду как на обед. \\
\hline Sófia & София \\
\hline $\begin{array}{l}\text { Sim, está bem - o fogo o consumiria. Mas e } \\
\text { se não? }\end{array}$ & Да, хорошо - сгорите, если ж нет? \\
\hline Cena 8 & Явление 8 \\
\hline Sófia, Liza, Tchátski, Fámussov & София, Лиза, Чацкий, Фамусов. \\
\hline Fámussov & Фамусов \\
\hline Mais esse outro agora. & Вот и другой! \\
\hline Sófia & София \\
\hline Ah, paizinho, o sonho virou realidade. & Ах, батюшка, сон в руку. \\
\hline (sai.) & $($ (Уходит.) \\
\hline Fámussov & Фамусов \\
\hline (para ela, na sequência, à meia voz) & (ей вслед вполголоса) \\
\hline Um pesadelo. & Проклятый сон. \\
\hline Cena 9 & Явление 9 \\
\hline $\begin{array}{l}\text { Fámussov, Tchátski (olha em direção à } \\
\text { porta pela qual Sófia sai) }\end{array}$ & $\begin{array}{l}\text { Фамусов, Чацкий (смотрит на дверь, в } \\
\text { которую София вышла) }\end{array}$ \\
\hline
\end{tabular}




\section{Fámussov}

Que peça nos pregou!

Em três anos não escreveu nem uma linha! E de repente estoura aqui como um trovão. Abraçam-se.

Salve, amigo, salve, irmão!

Conte-me, tenho certeza de que você tem pronta

Uma quantidade considerável de notícias? Vamos, sente-se, me informe sobre tudo o quanto antes.

Sentam-se.

\section{Tchástki}

(distraidamente)

Como Sófia tornou-se mais bela!

\section{Fámussov}

Para vocês, jovens, não há outro assunto,

Além de notar a beleza das moças:

Ela lhe disse algo, assim de passagem,

Pois você está me parecendo esperançoso e enfeitiçado.

\section{Tchátski}

Ah! Eu mal me lisonjeio com as esperanças.

\section{Fámussov}

$<<$ O sonho virou realidade $>>$ - ela dignou-se a cochichar para mim,

Pode imaginar...

\section{Фамусов}

Ну выкинул ты штуку!

Три года не писал двух слов!

И грянул вдруг как с облаков.

(Обнимаются.)

Здорово, друг, здорово, брат, здорово.

Рассказывай, чай у тебя готово

Собранье важное вестей?

Садись-ка, объяви скорей.

(Садятся.)

\section{Чацкий}

(рассеянно)

Как Софья Павловна у вас похорошела!

\section{Фамусов}

Вам, людям молодым, другого нету дела, Как замечать девичьи красоты:

Сказала что-то вскользь, а ты,

Я чай, надеждами занесся, заколдован.

\section{Чацкий}

Ax! нет; надеждами я мало избалован.

\section{Фамусов}

"Сон в руку" - мне она изволила шепнуть,

Вот ты задумал... 


\begin{tabular}{|c|c|}
\hline Tchátski & Чацкий \\
\hline Eu? - De maneira alguma. & Я? - Ничуть. \\
\hline Fámussov & Фамусов \\
\hline Sobre o que ela sonhou? Que é isso? & О ком ей снилось? что такое? \\
\hline Tchátski & Чацкий \\
\hline De novo, eu não sou adivinho. & Я не отгадчик снов. \\
\hline Fámussov & Фамусов \\
\hline Não acredito nela, tudo é infundado. & Не верь ей, все пустое. \\
\hline Tchátski & Чацкий \\
\hline Eu acredito nos meus próprios olhos; & Я верю собственным глазам; \\
\hline Eu assino em baixo que nunca encontrei & Век не встречал, подписку дам, \\
\hline Quem fosse ainda que um pouco como ela. & Чтоб было ей хоть несколько подобно! \\
\hline Fámussov & Фамусов \\
\hline $\begin{array}{l}\text { Ele não sabe falar de outro assunto. Mas } \\
\text { conte-me em detalhes: }\end{array}$ & Он все свое. Да расскажи подробно, \\
\hline Onde esteve? Vagou por tantos anos! & Где был? Скитался столько лет! \\
\hline De onde veio agora? & Откудова теперь? \\
\hline Tchátski & Чацкий \\
\hline Agora nem consigo pensar nisso! & Теперь мне до того ли! \\
\hline Quis percorrer o mundo todo, & Хотел объехать целый свет, \\
\hline Mas não percorri nem a centésima parte. & И не объехал сотой доли. \\
\hline (Levanta-se apressadamente) & (Bстает поспешно.) \\
\hline Perdoe-me: eu me apressei em vê-los & Простите; я спешил скорее видеть вас, \\
\hline $\begin{array}{l}\text { E nem passei em casa. Com licença! Voltarei } \\
\text { em uma hora, }\end{array}$ & Не заезжал домой. Прощайте! Через час \\
\hline Não esquecerei os mínimos detalhes, & Явлюсь, подробности малейшей не забуду; \\
\hline Você será o primeiro. Depois, poderá contar & Вам первым, вы потом рассказывайте всюду. \\
\hline
\end{tabular}




\begin{tabular}{|c|c|}
\hline (à porta.) & (В дверях.) \\
\hline Como ela está bela! & Как хороша! \\
\hline (sai.) & (Уходит.) \\
\hline Cena 10 & Явление 10 \\
\hline Fámussov & Фамусов \\
\hline$(s o ́)$ & $($ один) \\
\hline Qual dos dois será? & Который же из двух? \\
\hline$<<$ Ah! Paizinho, o sonho virou realidade! >> & "Ах! батюшка, сон в руку!" \\
\hline E me disse isso em voz alta! & И говорит мне это вслух! \\
\hline $\begin{array}{l}\text { Aí está, sou o culpado e admito: como eu } \\
\text { estava errado! }\end{array}$ & Ну, виноват! Какого ж дал я крюку! \\
\hline $\begin{array}{l}\text { Faz pouco que Moltchálin colocou uma } \\
\text { suspeita na minha cabeça. }\end{array}$ & Молчалин давиче в сомненье ввел меня. \\
\hline $\begin{array}{l}\text { Agora... Saí da lama para meter-me em um } \\
\text { atoleiro: }\end{array}$ & Теперь... да в полмя из огня: \\
\hline $\begin{array}{l}\text { Aquele é um miserável, e esse outro, um } \\
\text { dândi }{ }^{\text {ii; }}\end{array}$ & Тот нищий, этот франт-приятель; \\
\hline Um esbanjador contumaz, um folgazão! & Отъявлен мотом, сорванцом, \\
\hline Deus, que fardo é para um pai educar uma & Что за комиссия, Создатель, \\
\hline filha crescida! - & Быть взрослой дочери отцом! \\
\hline (Sai.) & (Уxodum.) \\
\hline Fim do Primeiro Ato. & Конец I действия \\
\hline
\end{tabular}




\section{ATO II}

\section{Cena 1}

Fámussov, criado.

\section{Fámussov}

Pietrúchka, sempre de traje novo,

E os cotovelos sempre rotos. Vamos, pegue o calendário ${ }^{\mathrm{jj}}$;

Leia. Não, não! Não como um sacristão ${ }^{\mathrm{kk}}$, Mas com sentimento, com tino, com disposição.

Não, espere. - Na próxima semana,

Escreva na agenda:

“Terça-feira, fui chamado à casa de Prascóvia Fiodorovna para comer trutas". O mundo, que beleza!

Vamos filosofar - e dá-lhe a cabeça girar;

Ora poupamos, ora almoçamos:

Comer por três horas, e, por três dias, a cozinhar $^{11 !}$

Vamos, marque no mesmo dia... Não, não, "Na quinta, fui chamado a um funeral." Oh, gênero humano! Esquecem-se Para onde é que todos nós vamos, Para aquele caixão: sem mais sentar ou levantar!

Mas quem tenciona deixar seu legado De uma existência louvável, veja um exemplo:

O falecido era um camareiro ${ }^{\mathrm{mm}}$ respeitável, De posses da chave ${ }^{\mathrm{nn}}$, passou-a também ao

\section{ДЕЙСТВИЕ II}

\section{Явление 1}

Фамусов, слуга.

\section{Фамусов}

Петрушка, вечно ты с обновкой, С разодранным локтем. Достань-ка календарь;

Читай не так, как пономарь, А с чувством, с толком, с расстановкой.

Постой же. - На листе черкни на записном, Противу будущей недели:

К Прасковье Федоровне в дом

Во вторник зван я на форели.

Куда как чуден создан свет!

Пофилософствуй - ум вскружится;

То бережешься, то обед:

Ешь три часа, а в три дни не сварится!

Отметь-ка, в тот же день... Нет, нет.

В четверг я зван на погребенье.

Ох, род людской! пришло в забвенье, Что всякий сам туда же должен лезть, В тот ларчик, где ни стать, ни сесть.

Но память по себе намерен кто оставить Житьем похвальным, вот пример:

Покойник был почтенный камергер,

С ключом, и сыну ключ умел доставить; 
filho,

Era rico e na riqueza, o matrimônio;

Богат, и на богатой был женат;

Casou também aos filhos, aos netos;

Переженил детей, внучат;

Morreu; Todos se lembram dele com pesar.

Kuzmá Pietrovitch! Que a paz esteja contigo!

Ah, esses figurões que vivem e morrem em Moscou! -

Escreva: na quinta-feira, uma coisa leva a outra e,

Talvez, na sexta, ou, quem sabe, no sábado, Devo comparecer ao batizado do filho da viúva do médico.

Ela ainda não deu à luz, mas pelas contas, Pelas minhas contas: está na hora.

Cena 2

Fámussov, Criado, Tchátski.

\section{Fámussov}

Ah, Aleksandr Andréievitch! Eu lhe peço, Vamos, sente-se.

\section{Tchátski}

Está ocupado?

\section{Fámussov}

(ao criado)

Vá.

(O criado sai.)

Sim, estamos levando da mente ao papel alguns assuntos diversos.

Se esquecermos, é para lá que olharemos.

Скончался; все о нем прискорбно поминают.

Кузьма Петрович! Мир ему! -

Что за тузы в Москве живут и умирают! -

Пиши: в четверг, одно уж к одному,

А может в пятницу, а может и в субботу,

Я должен у вдовы, у доктории, крестить.

Она не родила, но по расчету

По моему: должна родить...

Явление 2

Фамусов, слуга, Чацкий.

\section{Фамусов}

А! Александр Андреич, просим,

Садитесь-ка.

\section{Чацкий}

Вы заняты?

\section{Фамусов}

(слуге)

Поди.

(Слуга уходит.)

Да, разные дела на память в книгу вносим,

Забудется, того гляди. 


\section{Tchátski}

Algo no senhor não vai bem,

Diga-me, por quê? Não chego em boa hora?

Aconteceu algo a Sófia Pavlovna?...

Seu rosto e movimentos estão agitados.

\section{Fámussov}

Ah! O mistério! Vejam só, meu caro, está desvendado:

Não estou alegre! Na minha idade

Não é normal sair por aí, saltitando!

\section{Tchátski}

Ninguém quer que o faça;

Eu só lhe perguntei um bocado

Sobre Sófia Pávlovna: talvez esteja doente?

\section{Fámussov}

Arre, Deus me livre!

Repete a mesma coisa cinco mil vezes!

Ora se Sófia Pávlovna não é a mais bonita do mundo,

Ora se Sófia Pávlovna está doente -

Diga, gosta dela?

Você correu o mundo; será que não quer se casar?

\section{Tchátski}

E que isso lhe interessa?

\section{Fámussov}

\section{Чацкий}

Вы что-то не веселы стали;

Скажите, отчего? Приезд не в пору мой?

Уж Софье Павловне какой

Не приключилось ли печали?..

У вас в лице, в движеньях суета.

\section{Фамусов}

Ax! батюшка, нашел загадку:

Не весел я!.. В мои лета

Не можно же пускаться мне вприсядку!

\section{Чацкий}

Никто не приглашает вас;

Я только что спросил два слова

Об Софье Павловне: быть может, нездорова?

\section{Фамусов}

Тьфу, Господи прости! Пять тысяч раз

Твердит одно и то же!

То Софьи Павловны на свете нет пригоже,

То Софья Павловна больна.

Скажи, тебе понравилась она?

Обрыскал свет; не хочешь ли жениться?

\section{Чацкий}

А вам на что?

Фамусов 
Não faria mal perguntar,

Pois eu não sou apenas um parente,

Pelo menos, não é por acaso

Que me chamam de "Pai" desde o princípio.

\section{Tchátski}

Suponhamos que eu lhe peça a mão, o que me diria?

\section{Fámussov}

Em primeiro lugar, diria: chega de fantasias. Meu caro, você precisa administrar bem suas propriedades,

E, o principal, tem de servir ao Estado.

\section{Tchátski}

Servir seria bom, mas servilismo me dá náuseas ${ }^{\mathrm{oo}}$.

\section{Fámussov}

Pois vejam só, você é todo orgulho!

Pergunte como fizeram os pais.

Você aprenderia observando aos mais velhos:

Nós, por exemplo, ou o falecido tio Maksim

Pietróvitch, que comia não apenas em talheres de prata,

Mas também de ouro. Eram cem pessoas para lhe servir;

Tudo em ordem; quando andava era sempre de $z u g^{p p}$

Uma vida toda na corte, e em que corte!

Não era como nos dias de hoje,

Servia nos tempos da soberana Catarina ${ }^{\mathrm{qq}}$.
Меня не худо бы спроситься,

Ведь я ей несколько сродни;

По крайней мере искони

Отцом недаром называли.

\section{Чацкий}

Пусть я посватаюсь, вы что бы мне сказали?

\section{Фамусов}

Сказал бы я, во-первых: не блажи,

Именьем, брат, не управляй оплошно,

А, главное, поди-тка послужи.

\section{Чацкий}

Служить бы рад, прислуживаться тошно.

\section{Фамусов}

Вот то-то, все вы гордецы!

Спросили бы, как делали отцы?

Учились бы на старших глядя:

Мы, например, или покойник дядя,

Максим Петрович: он не то на серебре,

На золоте едал; сто человек к услугам;

Весь в орденах; езжал-то вечно цугом;

Век при дворе, да при каком дворе!

Тогда не то, что ныне,

При государыне служил Екатерине. 
Naquela época, todos eram importantes!

Altíssima influência...

Ao se cumprimentarem - o toupet não

desmanchava.

Um alto dignitário, na corte - e mais:

Era diferente dos outros até no modo de beber e comer.

Sim, nosso querido tio! Que príncipe o quê!

Que conde, que nada!

Um olhar sério, um caráter soberbo.

Quando se fazia necessário rastejar para ganhar algo,

Ele se curvava até o chão:

Na corte, acontecia-lhe de escorregar,

Caía de tal modo que por pouco não torcia o pescoço,

$\mathrm{O}$ velho se punha a gemer, a voz rouca:

Era condecorado com o mais imperial sorriso;

Dignavam-se a rir; e então o que ele fazia?

Soerguia-se, endireitava-se, fazia menção de reverenciar,

E caía de novo - já de propósito, mais gargalhadas, e assim ele repetia tudo pela terceira vez.

Então? Que ele lhe parece? Ele sim é que é inteligente.

Quando caía doente, levantava recuperado.

Por isso, quem era sempre convidado para o whist ${ }^{\mathrm{rr}}$ ?

Quem escutava na corte uma palavra amistosa?

Maksím Pietróvitch! Quem, acima de todos, gozava de estima?
А в те поры все важны! в сорок пуд...

аскланяйся - тупеем не кивнут.

Вельможа в случае - тем паче,

Не как другой, и пил и ел иначе.

А дядя! что твой князь? что граф?

Сурьезный взгляд, надменный нрав.

Когда же надо подслужиться,

И он сгибался вперегиб:

На куртаге ему случилось обступиться;

Упал, да так, что чуть затылка не пришиб;

Старик заохал, голос хрипкой;

Был высочайшею пожалован улыбкой;

Изволили смеяться; как же он?

Привстал, оправился, хотел отдать поклон,

Упал вдругорядь - уж нарочно,

А хохот пуще, он и в третий так же точно.

A? как по вашему? по нашему - смышлен.

Упал он больно, встал здорово.

Зато, бывало, в вист кто чаще приглашен?

Кто слышит при дворе приветливое слово?

Максим Петрович! Кто пред всеми знал почет? 


\begin{tabular}{|c|c|}
\hline Maksím Pietrótvitch! Isso não é brincadeira! & Максим Петрович! Шутка! \\
\hline Quem conseguia graus e concedia pensões? & В чины выводит кто и пенсии дает? \\
\hline $\begin{array}{l}\text { Maksím Pietróvitch. Sim! Nos dias de hoje, } \\
\text { será que vocês conseguem fazer o mesmo? }\end{array}$ & $\begin{array}{l}\text { Максим Петрович. Да! Вы, нынешние, - } \\
\text { нутка! }\end{array}$ \\
\hline Tchátski & Чацкий \\
\hline É isso mesmo! Você pode lamentar, & И точно, начал свет глупеть, \\
\hline Dizendo que o mundo tornou-se mais tolo. & Сказать вы можете вздохнувши; \\
\hline Como confrontar e observar & Как посравнить да посмотреть \\
\hline O século atual com o prévio: & Век нынешний и век минувший: \\
\hline Tradição recente, na qual é difícil crerss: & Свежо предание, а верится с трудом, \\
\hline Salvava-se aquele que melhor se curvava; & Как тот и славился, чья чаще гнулась шея; \\
\hline $\begin{array}{l}\text { Levavam a testa até o chão, arriscavam e } \\
\text { ganhavam, }\end{array}$ & Как не в войне, а в мире брали лбом, \\
\hline Muito mais na paz do que na guerra. & Стучали об пол не жалея! \\
\hline $\begin{array}{l}\text { Os necessitados são aqueles que por } \\
\text { arrogância permanecem na obscuridade, }\end{array}$ & Кому нужда: тем спесь, лежи они в пыли, \\
\hline $\begin{array}{l}\text { Ao passo que os que estão no alto, por lisonja, } \\
\text { São cobertos de adulações. }\end{array}$ & А тем, кто выше, лесть, как кружево, плели. \\
\hline Genuíno foi o século de horror e submissão ${ }^{\text {tt }}$, & Прямой был век покорности и страха, \\
\hline Tudo sob a máscara de diligência ao czar. & Все под личиною усердия к царю. \\
\hline Não é sobre o seu tiozinho que falo; & Я не об дядюшке об вашем говорю; \\
\hline Nós não vamos perturbar suas cinzas: & Его не возмутим мы праха: \\
\hline Mas, enquanto isso, quem é que deseja agora, & Но между тем кого охота заберет, \\
\hline Mesmo que pelo servilismo mais ardente, & Хоть в раболепстве самом пылком, \\
\hline Fazer rir ao povo, & Теперь, чтобы смешить народ, \\
\hline E, de modo atrevido, sacrificar o pescoço? & Отважно жертвовать затылком? \\
\hline Outro velhinho de sua idade, & А сверстничек, а старичок \\
\hline Ao olhar para aquela escorregadela, & Иной, глядя на тот скачок, \\
\hline Estragando sua pele decrépita, & И разрушаясь в ветхой коже, \\
\hline $\begin{array}{l}\text { Certamente repetiria: “Ah! Se eu também } \\
\text { pudesse!" }\end{array}$ & Чай приговаривал: "Ах! если бы мне тоже!" \\
\hline Mesmo que haja, em todas as partes, & Хоть есть охотники поподличать везде, \\
\hline
\end{tabular}




\begin{tabular}{|c|c|}
\hline voluntários a portar-se vilmente, & \\
\hline $\begin{array}{l}\text { O riso agora espanta e mantém a vergonha } \\
\text { sob controle; }\end{array}$ & $\begin{array}{l}\text { Да нынче смех страшит и держит стыд в } \\
\text { узде; }\end{array}$ \\
\hline $\begin{array}{l}\text { Não sem razão os seus soberanos pouco se } \\
\text { compadecem. }\end{array}$ & Недаром жалуют их скупо государи. \\
\hline Fámussov & Фамусов \\
\hline Ah! Meu Deus! Um carbonário ${ }^{\mathrm{uu} !}$ & Ах! Боже мой! он карбонари! \\
\hline Tchátski & Чацкий \\
\hline Não, agora não há mais desses no mundo. & Нет, нынче свет уж не таков. \\
\hline Fámussov & Фамусов \\
\hline Homem perigoso! & Опасный человек! \\
\hline Tchátski & Чацкий \\
\hline Qualquer um que respire mais livremente, & Вольнее всякий дышит \\
\hline $\begin{array}{l}\text { Não se apressa para se juntar a um bando de } \\
\text { tolos. }\end{array}$ & И не торопится вписаться в полк шутов. \\
\hline Fámussov & Фамусов \\
\hline $\begin{array}{l}\text { Mas olha como fala! E fala como se } \\
\text { escrevesse! }\end{array}$ & Что говорит! и говорит, как пишет! \\
\hline Tchátski & Чацкий \\
\hline $\begin{array}{l}\text { Na casa dos protetores, boceja-se olhando } \\
\text { para o teto, }\end{array}$ & У покровителей зевать на потолок, \\
\hline Cala-se, bajula-se, e almoça-se, & Явиться помолчать, пошаркать, пообедать, \\
\hline $\begin{array}{l}\text { Aproxima-se de uma cadeira, ergue-se um } \\
\text { lenço. }\end{array}$ & Подставить стул, поднять платок. \\
\hline Fámussov & Фамусов \\
\hline Ele quer pregar a liberdade! & Он вольность хочет проповедать! \\
\hline
\end{tabular}




\section{Tchátski}

Há quem viaje, mas há quem na aldeia fique...

\section{Fámussov}

Ele não reconhece até as autoridades!

\section{Tchátski}

Serve-se a uma causa e não a um posto...

\section{Fámussov}

Eu proibiria severamente esses senhores

De se aproximarem da capital à distância de um tiro de espingarda.

\section{Tchátski}

Enfim, eu lhe deixo em paz...

\section{Fámussov}

Tenha santa paciência! É de lastimar, não posso mais!

\section{Tchátski}

Eu amaldiçoei de modo implacável o seu século,

E me retiro:

Reduza a metade do que eu disse,

Mesmo que para os nossos dias de hoje.

Já que é assim, eu não vou lamentar.

\section{Fámussov}

E eu não quero saber de você, eu não suporto libertinagem.

\section{Чацкий}

Кто путешествует, в деревне кто живет...

\section{Фамусов}

Да он властей не признает!

\section{Чацкий}

Кто служит делу, а не лицам...

\section{Фамусов}

Строжайше б запретил я этим господам На выстрел подъезжать к столицам.

\section{Чацкий}

Я наконец вам отдых дам...

\section{Фамусов}

Терпенья, мочи нет, досадно.

\section{Чацкий}

Ваш век бранил я беспощадно,

Предоставляю вам во власть:

Откиньте часть,

Хоть нашим временам в придачу;

Уж так и быть, я не поплачу.

\section{Фамусов}

И знать вас не хочу, разврата не терплю. 


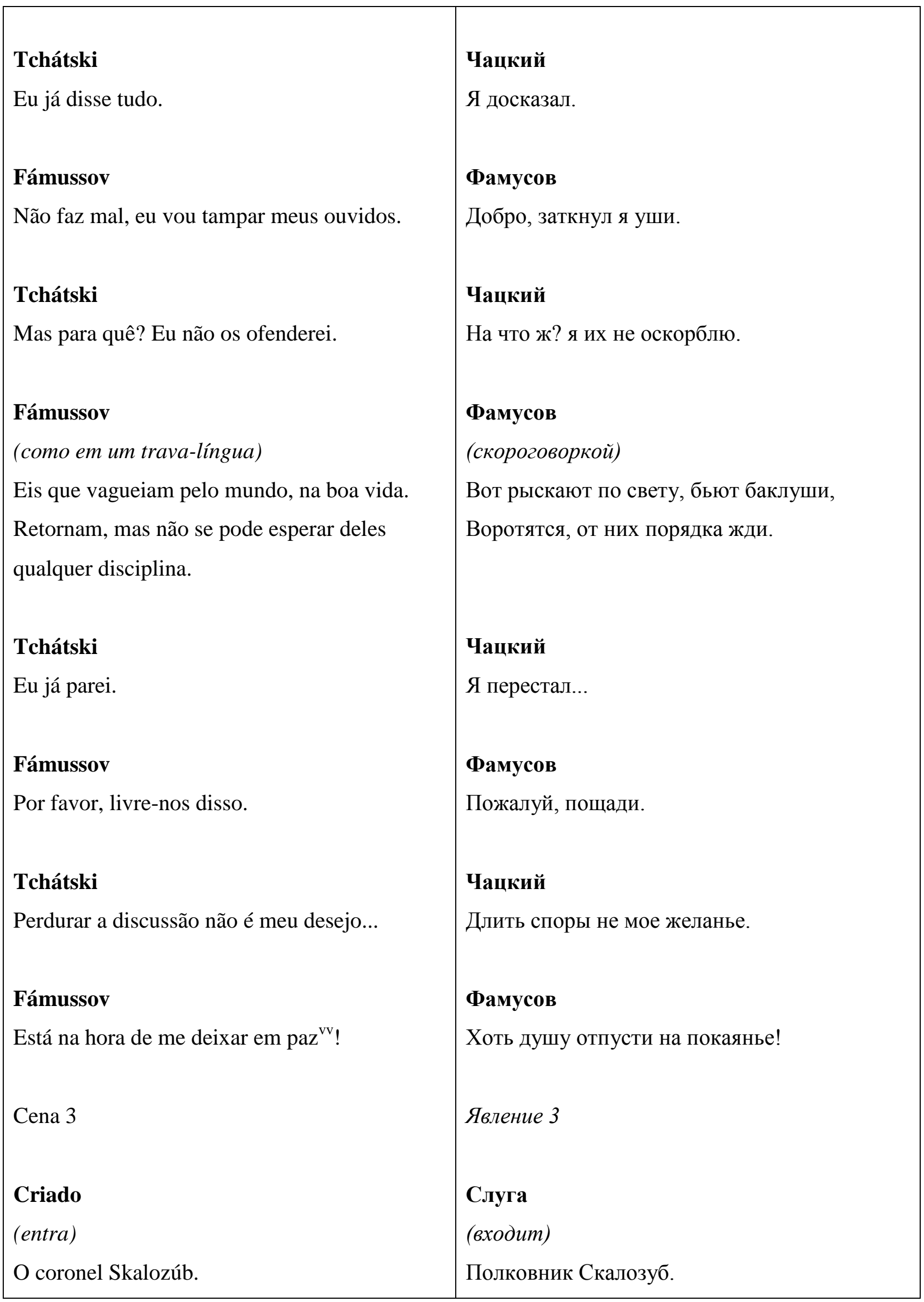




\section{Fámussov}

(não vê e nem ouve nada)

Já lhe mandei embora, você irá parar na cadeia,

Irá à justiça, eu asseguro, e sem falta.

\section{Tchátski}

Alguém o chama na casa.

\section{Fámussov}

Eu não ouço, à justiça!

\section{Tchátski}

Um homem o chama com um informe.

\section{Fámussov}

Não ouço, à justiça! À Justiça!

\section{Tchátski}

Vire para trás, estão chamando.

\section{Fámussov}

Como? Um motim? Pois já deveria esperar uma sodoma $^{\mathrm{ww}}$ !

\section{Criado}

Coronel Skalozúb. O senhor ordena recebê10 ?

Fámussov

(levanta)

Asno! Devo repetir pela centésima vez?
Фамусов

(ничего не видит и не сльишт)

Тебя уж упекут

Под суд, как пить дадут.

\section{Чацкий}

Пожаловал к вам кто-то на дом.

\section{Фамусов}

Не слушаю, под суд!

\section{Чацкий}

К вам человек с докладом.

\section{Фамусов}

Не слушаю, под суд! под суд!

\section{Чацкий}

Да обернитесь, вас зовут.

Фамусов (оборачивается)

A? бунт? ну так и жду содома.

\section{Слуга}

Полковник Скалозуб. Прикажете принять?

\section{Фамусов}

(вcmaem)

Ослы! сто раз вам повторять? 


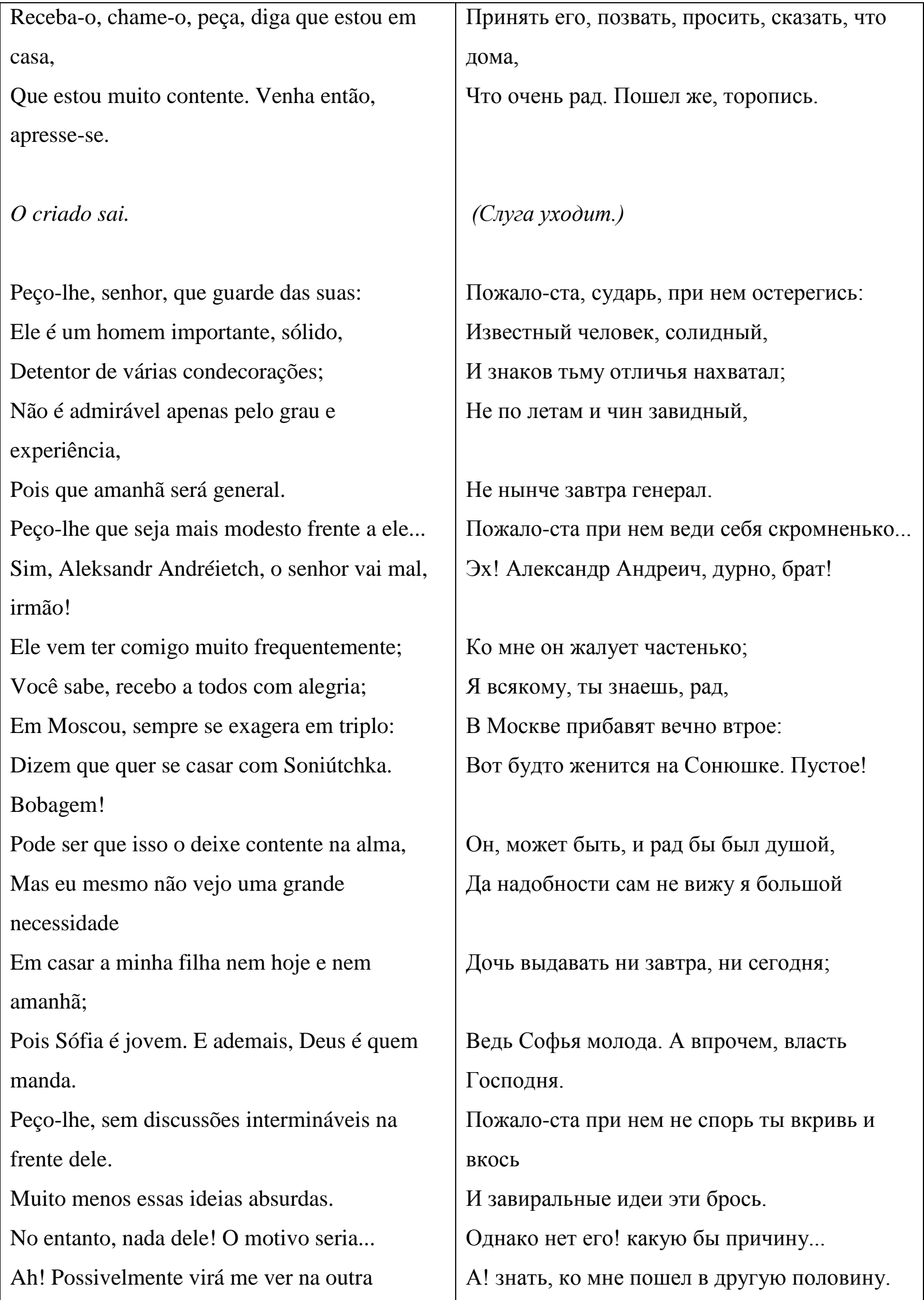




\begin{tabular}{|c|c|}
\hline $\begin{array}{l}\text { metade. } \\
\text { (sai apressadamente) }\end{array}$ & (Поспешно уходит.) \\
\hline Cena 4 & Явление 4 \\
\hline Tchátski & Чацкий \\
\hline Como se agita! Que rapidez! & Как суетится! что за прыть? \\
\hline $\begin{array}{l}\text { E Sófia? - Será mesmo que ele não é um } \\
\text { pretendente? }\end{array}$ & $\begin{array}{l}\text { А Софья? - Нет ли впрямь тут жениха } \\
\text { какого? }\end{array}$ \\
\hline $\begin{array}{l}\text { Desde quando me evitam como a um } \\
\text { estranho! }\end{array}$ & С которых пор меня дичится, как чужого! \\
\hline Como seria se ela estivesse aqui!! & Как здесь бы ей не быть!!. \\
\hline $\begin{array}{l}\text { Quem é esse Skalozúb? O pai delira } \\
\text { fortemente com ele. }\end{array}$ & Кто этот Скалозуб? отец им сильно бредит, \\
\hline E pode ser que não somente o pai... & А может быть, не только что отец... \\
\hline $\begin{array}{l}\text { Ah! Aquele que partiu para longe por três } \\
\text { anos, }\end{array}$ & Ах! тот скажи любви конец, \\
\hline É aquele que diz fim ao amor. & Кто на три года вдаль уедет. \\
\hline Cena 5 & Явление 5 \\
\hline Tchátski, Fámussov, Skalozúb. & Чацкий, Фамусов, Скалозуб. \\
\hline Fámussov & Фамусов \\
\hline Serguéi Serguéiitch, por aqui conosco, senhor, & Сергей Сергеич, к нам сюда-с. \\
\hline Peço-lhe docilmente, aqui está mais quente; & Прошу покорно, здесь теплее; \\
\hline Está com frio, nós o aquecemos; & Прозябли вы, согреем вас; \\
\hline $\begin{array}{l}\text { Nós levantaremos a portinha do aquecedor } \\
\text { mais depressa. }\end{array}$ & Отдушничек отвернем поскорее. \\
\hline $\begin{array}{l}\text { Skalozúb }^{\mathbf{x x}} \\
\text { (com um tom denso e baixo) }\end{array}$ & $\begin{array}{l}\text { Скалозуб } \\
\text { (густым басом) }\end{array}$ \\
\hline Para que se preocupar comigo! & Зачем же лазить, например, \\
\hline Por ser um oficial honrado, fico embaraçado. & Самим!.. Мне совестно, как честный офицер. \\
\hline
\end{tabular}




\section{Fámussov}

Será que não devo levantar nenhum dedo aos amigos!

Serguéi Serguéiitch, meu caro! Descanse o chapéu, tire a espada;

Eis um sofá, fique à vontade.

\section{Skalozúb}

Para onde ordenar, é só sentar.

Sentam-se os três. Tchátski a uma certa distância.

\section{Fámussov}

Ah! Meu amigo, devo dizer, não posso esquecer:

Permita-nos considerá-lo como um dos nossos

- Quando distante, não há herança;

Se não sabia, eu muito menos, -

Graças ao seu irmão, que nos contou -

O que você é de Nastássia Nikolavna?

\section{Skalozúb}

Não sei, senhor, desculpe;

Nós não servimos juntos.

\section{Fámussov}

Serguéi Serguéiitch, será isso possível!

Não! Eu só faço é rastejar quando encontro um parente;

Eu iria até o fundo do mar para encontrá-lo. Para mim é muito raro ter estranhos como

\section{Фамусов}

Неужто для друзей не делать мне ни шагу,

Сергей Сергеич дорогой! Кладите шляпу, сденьте шпагу;

Вот вам софа, раскиньтесь на покой.

\section{Скалозуб}

Куда прикажете, лишь только бы усесться.

(Садятся все трое. Чацкий поодаль.)

\section{Фамусов}

Ax! батюшка, сказать, чтоб не забыть:

Позвольте нам своими счесться, Хоть дальними, - наследства не делить;

Не знали вы, а я подавно, -

Спасибо научил двоюродный ваш брат, Как вам доводится Настасья Николавна?

\section{Скалозуб}

Не знаю-с, виноват;

Мы с нею вместе не служили.

\section{Фамусов}

Сергей Сергеич, это вы ли!

Нет! я перед родней, где встретится, ползком;

Сыщу ее на дне морском.

При мне служащие чужие очень редки; 
empregados;

São na maioria filhos da minha irmã e cunhada;

Só não sou parente de Moltchálin,

Ele é um homem de negócios

E, por outro lado, é experiente.

Como poderia deixar de ajudar um parente a conseguir um posto!

No entanto o seu irmão é meu amigo e diz Que graças a você recebeu uma infinidade de vantagens pelo serviço.

\section{Skalozúb}

Em 1813, nós nos distinguíamos

No trigésimo regimento de caçadores, e depois no quadragésimo quinto.

\section{Fámussov}

Sim! Que felicidade para quem tem tamanho filho!

Você tem, me parece, uma ordenzinha na lapela?

\section{Skalozúb}

Em três de agosto, nós nos reunimos na trincheira:

Deram-lhe uma faixa, e para mim amarraram no pescoço.

\section{Fámussov}

Homem educado, e veja que valente!

Que homem magnífico é o seu primo.
Все больше сестрины, свояченицы детки;

Один Молчалин мне не свой, И то затем, что деловой.

Как станешь представлять к крестишку ли, к местечку,

Ну как не порадеть родному человечку!.

Однако братец ваш мне друг и говорил, Что вами выгод тьму по службе получил.

\section{Скалозуб}

В тринадцатом году мы отличались с братом В тридцатом егерском, а после в сорок пятом.

\section{Фамусов}

Да, счастье, у кого есть эдакий сынок!

Имеет, кажется, в петличке орденок?

\section{Скалозуб}

За третье августа; засели мы в траншею:

Ему дан с бантом, мне на шею.

\section{Фамусов}

Любезный человек, и посмотреть - так хват. Прекрасный человек двоюродный ваш брат. 


\section{Skalozúb}

Mas, com toda a seriedade, ele adquiriu novas condutas.

A patente o acompanhou: ele largou de repente o serviço,

E, na aldeia, pôs-se a ler livros.

\section{Fámussov}

Que juventude!... Ler!... E depois, tarde demais!..

Você comportou-se corretamente,

Já é coronel há muito, ainda que sirva há pouco.

\section{Skalozúb}

Estou muito feliz com meus companheiros, Sempre há vagas;

Pois os mais velhos encerram a carreira jovens,

E outros, veja, são mortos.

\section{Fámussov}

Sim, quando Deus procura por alguém, Ele o ergue!

\section{Skalozúb}

Acontece de alguém ter mais sorte que eu.

Nós temos na nossa décima quinta divisão, não precisa ir além,

Um homem, o general da brigada.

\section{Скалозуб}

Но крепко набрался каких-то новых правил.

Чин следовал ему; он службу вдруг оставил,

В деревне книги стал читать.

\section{Фамусов}

Вот молодость!.. - читать!.. а после хвать!..

Вы повели себя исправно:

Давно полковники, а служите недавно.

\section{Скалозуб}

Довольно счастлив я в товарищах моих, Вакансии как раз открыты;

То старших выключат иных,

Другие, смотришь, перебиты.

\section{Фамусов}

Да, чем кого Господь поищет, вознесет!

\section{Скалозуб}

Бывает, моего счастливее везет.

У нас в пятнадцатой дивизии, не дале,

Об нашем хоть сказать бригадном генерале.

\section{Фамусов}

\section{Fámussov}


Perdoe-me, mas o que lhe faz falta?

\section{Skalozúb}

Não lastimo por não sair por aí com promoções,

No entanto, levou dois anos para eu ser coronel.

\section{Fámussov}

$\mathrm{Na}$ busca por ser coronel?

Mas em compensação, é claro, atrás de você

Arrasta-se outro e de longe.

\section{Skalozúb}

Não, senhor, encontra-se quem seja mais velho que eu no regimento,

Mas eu sirvo desde 1819;

Sim, há muitos meios de ganhar patentes; $\mathrm{Eu}$ as julgo como um verdadeiro filósofo: Para mim só falta conseguir a de general.

\section{Fámussov}

E julga gloriosamente.

Que Deus lhe dê saúde e o grau de General; E ademais:

Está na hora de falar da esposa do General.

\section{Skalozúb}

Casar? Eu não tenho absolutamente nada contra isso.

\section{Fámussov}

É mesmo? Há quem tenha uma irmã, sobrinha, filha;
Помилуйте, а вам чего недостает?

\section{Скалозуб}

Не жалуюсь, не обходили,

Однако за полком два года поводили.

\section{Фамусов}

В погонь ли за полком?

Зато, конечно, в чем другом

За вами далеко тянуться.

\section{Скалозуб}

Нет-с, старее меня по корпусу найдутся,

Я с восемьсот девятого служу;

Да, чтоб чины добыть, есть многие каналы;

Об них как истинный философ я сужу:

Мне только бы досталось в генералы.

\section{Фамусов}

И славно судите, дай Бог здоровья вам

И генеральский чин; а там

Зачем откладывать бы дальше

Речь завести об генеральше?

\section{Скалозуб}

Жениться? Я ничуть не прочь.

\section{Фамусов}

Что ж? у кого сестра, племянница есть, дочь; 
Pois em Moscou há muitas na idade de $\operatorname{casar}^{\mathrm{yy}}$

Quê? Reproduzem-se ano a ano;

Mas, paizinho, confesse, por pouco não

Se encontra uma capital como Moscou.

\section{Skalozúb}

A extensão é de vasta grandeza.

\section{Fámussov}

O estilo, meu amigo, é de um modo

extraordinário,

Em tudo há suas normas:

Veja, por exemplo, há muito já se diz que a honra passa de pai para filho.

Que seja medíocre, mas que acumule um

Patrimônio de duas mil almas:

isso é que é escolhido.

E outro, mesmo que seja esperto, inflado por qualquer arrogância,

Com a reputação de sabichão,

Não irão aceitá-lo em sua família. Isso não nos surpreende,

Pois só aqui ainda é que se tem em alta conta a fidalguia.

Mas será que é só isso? Entregue-lhes o pão e o sal ${ }^{\mathrm{Zz}}$ :

Quem quer nos conceder uma visita, tenha bondade;

A porta está aberta a todos, sejam convidados ou não,

Especialmente aos estrangeiros;

Honrado ou não, dá no mesmo:
В Москве ведь нет невестам перевода;

Чего? плодятся год от года;

A, батюшка, признайтесь, что едва

Где сыщется столица, как Москва.

\section{Скалозуб}

Дистанции огромного размера.

\section{Фамусов}

Вкус, батюшка, отменная манера;

На все свои законы есть:

Вот, например, у нас уж исстари ведется,

Что по отцу и сыну честь:

Будь плохенький, да если наберется

Душ тысячки две родовых, -

Тот и жених.

Другой хоть прытче будь, надутый всяким чванством,

Пускай себе разумником слыви,

А в семью не включат. На нас не подиви.

Ведь только здесь еще и дорожат дворянством.

Да это ли одно? возьмите вы хлеб-соль:

Кто хочет к нам пожаловать, - изволь;

Дверь отперта для званных и незванных,

Особенно из иностранных;

Хоть честный человек, хоть нет, 
O almoço será servido a todos.

Renda-se de corpo e alma,

Em todos os moscovitas há algo de especial.

Veja só a nossa juventude,

Nossa adolescência - os filhos e netos:

Nós os repreendemos se for exigido,

E os professores os ensinam por quinze anos!

E os nossos velhotes?? - Como eles

condenam o fervor sobre os fatos, sua palavra é uma sentença.

São todos nobres, não temem a ninguém,

E, se for o caso, comentam sobre o novo governo

E caso alguém os surpreenda em uma conversa... Que desgraça!

Não que sejam de introduzir novidades.

Nunca!

Deus nos salve!... Não. Pegam no pé sobre toda e qualquer coisa e nunca sem razão.

Discutem, fazem barulho e... Se vão.

Perfeitos chanceleres aposentados - pela inteligência!

Eu lhe digo: ainda não chegou o tempo

De vivermos sem eles.

E as damas? - Experimenta só, quem se mete com elas, está dominado;

Julgam a todos, em todas as partes, acima delas não há juízes;

Quando insurge uma rebelião geral nas cartas, Deus lhe dê paciência, pois eu mesmo fui casado.

Coloquem-nas para comandar um exército! Mandem-nas presenciar sessões no Senado!
Для нас равнехонько, про всех готов обед.

Возьмите вы от головы до пяток,

На всех московских есть особый отпечаток. Извольте посмотреть на нашу молодежь,

На юношей - сынков и внучат.

Журим мы их, а если разберешь, -

В пятнадцать лет учителей научат!

А наши старички?? - Как их возьмет задор, Засудят об делах, что слово - приговор, -

Ведь столбовые * все, в ус никого не дуют; И об правительстве иной раз так толкуют,

Что если б кто подслушал их... беда!

Не то, чтоб новизны вводили, - никогда,

Спаси нас Боже! Нет. А придерутся

К тому, к сему, а чаще ни к чему,

Поспорят, пошумят, и... разойдутся.

Прямые канцлеры в отставке - по уму!

Я вам скажу, знать, время не приспело, Но что без них не обойдется дело. -

А дамы? - сунься кто, попробуй, овладей;

Судьи всему, везде, над ними нет судей;

За картами когда восстанут общим бунтом, Дай Бог терпение, - ведь сам я был женат.

Скомандовать велите перед фрунтом! Присутствовать пошлите их в Сенат! 
Irína Vlassiévna! Lukéria Alekséievna!

Tatiána Iuriévna! Pulkhéria Andréievna!

E quem passar por suas filhinhas, é o fim!

Aqui esteve Sua Majestade, o rei prussiano;

Ele admirou-se muito com as donzelas

moscovitas,

Mas por sua boa conduta, não pelo rosto.

E precisamente, seria possível que fossem

mais bem criadas?!

Sabem então enfeitar-se

Com véus, veludos e tafetás,

Não dizem uma palavrinha na simplicidade,

Tudo vem com um gesto afetado.

Cantam os romances franceses,

Elevando as notas mais altas.

Possuem uma fraqueza em relação à gente militar,

E isto porque são patriotas.

Digo decididamente: é pouco provável

Encontrar uma capital como Moscou.

\section{Skalozúb}

Na minha opinião,

O incêndio contribuiu muito para o seu embelezamento. $^{\text {aaa }}$

\section{Fámussov}

Nem me lembre disso. Ainda nos traz um pouco de insatisfação ${ }^{\text {bbb }}$ :

Mas desde aqueles tempos as estradas, as calçadas,

As casas e tudo estão de um novo jeito ${ }^{\text {ccc }}$.
Ирина Власьевна! Лукерья Алексевна!

Татьяна Юрьевна! Пульхерия Андревна!

А дочек кто видал, всяк голову повесь...

Его величество король был прусский здесь,

Дивился не путем московским он девицам,

Их благонравью, а не лицам;

И точно, можно ли воспитаннее быть!

Умеют же себя принарядить

Тафтицей, бархатцем и дымкой,

Словечка в простоте не скажут, все с ужимкой;

Французские романсы вам поют

И верхние выводят нотки,

К военным людям так и льнут.

А потому, что патриотки.

Решительно скажу: едва

Другая сыщется столица, как Москва.

\section{Скалозуб}

По моему сужденью,

Пожар способствовал ей много к украшенью.

\section{Фамусов}

Не поминайте нам, уж мало ли крехтят!

C тех пор дороги, тротуары,

Дома и все на новый лад. 


\section{Tchátski}

Novas casas, mas velhos preconceitos.

Alegrem-se, pois eles não se destruirão.

Nem com os anos, nem com as modas e nem com os incêndios.

\section{Fámussov}

(Para Tchátski)

Ei, amarre um nó para lembrar ${ }^{\text {ddd; }}$

Eu lhe pedi para se calar, não é um grande serviço.

(Para Skalozúb)

Perdoe-me, meu caro. Senhor, veja, é

Tchátski,

Filho de meu amigo falecido Andrei Ilitch:

Não serve ao Estado, ou seja, ele não vê utilidade nisso,

Mas se quisesse, seria um homem eficaz.

Pena, muita pena, ele é esperto,

E escreve e traduz bem.

Não se pode deixar de lamentar, pois com tamanha inteligência...

\section{Tchátski}

Que tal jogar seus lamentos em cima de qualquer outro?

E os seus elogios me enojam.

\section{Fámussov}

Eu não estou só, todos também reprovam.

\section{Чацкий}

Дома новы, но предрассудки стары.

Порадуйтесь, не истребят

Ни годы их, ни моды, ни пожары.

\section{Фамусов}

(Чаикому)

Эй, завяжи на память узелок;

Просил я помолчать, не велика услуга.

\section{(Скалозубу)}

Позвольте, батюшка. Вот-с - Чацкого, мне друга,

Андрея Ильича покойного сынок:

Не служит, то есть в том он пользы не находит,

Но захоти - так был бы деловой.

Жаль, очень жаль, он малый с головой,

И славно пишет, переводит.

Нельзя не пожалеть, что с эдаким умом...

\section{Чацкий}

Нельзя ли пожалеть об ком-нибудь другом?

И похвалы мне ваши досаждают.

\section{Фамусов}

Не я один, все также осуждают.

\section{Чацкий}

\section{Tchátski}


E quem pode julgar? ${ }^{\text {eee }}-$ No passado,

Os inimigos irreconciliáveis de uma vida livre,

Sacavam suas opiniões de jornais esquecidos Como O tempo ${ }^{f f f}$, da época de Otchakov ${ }^{\text {ggg }} \mathrm{e}$ da conquista da Criméia;

Sempre prontos para a pronunciação,

Cantavam a mesma canção,

Não percebendo em relação a si

Que quanto mais velho, tanto pior.

Onde estão, mostre-nos, os pais de nossa pátria,

Os quais nós devemos ter como modelos?

Será que não são os que se tornaram ricos pelas pilhagens?

Frente ao tribunal, encontraram defesa nos amigos, nos parentes,

Erigindo suntuosos palácios,

Onde se despejam em festas e extravagâncias

E onde os seus clientes estrangeiros não ressuscitam

Os traços circundantes da vida passada.

E em Moscou, em almoços, jantares e danças,

A quem não fecham a boca?

Será que já não houve para mim desde a infância,

Planos de certa forma incompreensíveis,

Das crianças sendo introduzidas a pessoas influentes ${ }^{\text {hhh }}$ ?

Nestor ${ }^{i i i}$ era um desses nobres patifes,

Rodeado por uma multidão de criados.

Dedicados, salvaram-no por vezes a vida e a honra em seus crimes e querelas: e de repente,
А судьи кто? - За древностию лет

К свободной жизни их вражда непримирима,

Сужденья черпают из забытых газет

Времен Очаковских и покоренья Крыма;

Всегда готовые к журьбе,

Поют все песнь одну и ту же,

Не замечая об себе:

Что старее, то хуже.

Где, укажите нам, отечества отцы, *

Которых мы должны принять за образцы?

Не эти ли, грабительством богаты?

Защиту от суда в друзьях нашли, в родстве,

Великолепные соорудя палаты,

Где разливаются в пирах и мотовстве,

И где не воскресят клиенты-иностранцы *

Прошедшего житья подлейшие черты.

Да и кому в Москве не зажимали рты

Обеды, ужины и танцы?

Не тот ли, вы к кому меня еще с пелен,

Для замыслов каких-то непонятных,

Дитей возили на поклон?

Тот Нестор * негодяев знатных,

Толпою окруженный слуг;

Усердствуя, они в часы вина и драки

И честь и жизнь его не раз спасали: вдруг 
Ele os trocou por três galgos ${ }^{\mathrm{jjj}}$ !!!

Ou ainda aquele que, para organizar um baile aos servos,

Reuniu, em muitos vagões, crianças separadas de seus pais e mães ${ }^{\mathrm{kk}}$ ?!

Doido por Zéfiros e Cupidos,

Colocou toda Moscou para admirar a beleza delas!

Mas não conseguia manter seus credores na espera:

Todos os Cupidos e Zéfiros

Foram vendidos, um a um!!!

Eis aqueles que chegaram à velhice!

Eis a quem nós devemos respeitar por falta de opção!

Eis nossos severos juízes e apreciadores!

Agora, quando encontram um jovem como nós,

Um inimigo dos prazeres materiais,

Que não exige posições e nem graus,

Que é ávido pelo conhecimento e fita a

inteligência pela ciência,

Ou que em sua alma o próprio Deus incitou um ardor

Para com as criações artísticas, elevadas e magníficas -

No mesmo instante gritam: bandidagem!

Incêndio!

E ganham a fama de sonhadores! Perigosos!! -

Farda! Uma farda! No passado, em certa época,

Era costume abrigar-se nela, bela e bordada, Contra a pusilanimidade, a falta da razão;
На них он выменил борзые три собаки!!!

Или вон тот еще, который для затей

На крепостной балет согнал на многих фурах От матерей, отцов отторженных детей?!

Сам погружен умом в Зефирах и в Амурах, Заставил всю Москву дивиться их красе!

Но должников * не согласил к отсрочке:

Амуры и Зефиры все

Распроданы поодиночке!!!

Вот те, которые дожили до седин!

Вот уважать кого должны мы на безлюдьи!

Вот наши строгие ценители и судьи!

Теперь пускай из нас один,

Из молодых людей, найдется - враг исканий, Не требуя ни мест, ни повышенья в чин, В науки он вперит ум, алчущий познаний;

Или в душе его сам Бог возбудит жар

К искусствам творческим, высоким и рекрасным, -

Они тотчас: разбой! пожар!

И прослывет у них мечтателем! опасным!! Мундир! один мундир! он в прежнем их быту

Когда-то укрывал, расшитый и красивый, Их слабодушие, рассудка нищету; 


\begin{tabular}{|c|c|}
\hline $\begin{array}{l}\text { E nós, vestindo-a, estávamos no caminho da } \\
\text { felicidade! }\end{array}$ & И нам за ними в путь счастливый! \\
\hline $\begin{array}{l}\text { E para as mulheres, as filhas - que paixão } \\
\text { pela farda! }\end{array}$ & И в женах, дочерях - к мундиру та же страсть! \\
\hline $\begin{array}{l}\text { Será que há muito eu mesmo perdi essa } \\
\text { paixão? }\end{array}$ & Я сам к нему давно ль от нежности отрекся?! \\
\hline Agora eu já não me afundo nesta criancice; & Теперь уж в это мне ребячество не впасть; \\
\hline Mas como não se atrair por ela? & Но кто б тогда за всеми не повлекся? \\
\hline No tempo em que chegaram aqui da guarda, & Когда из гвардии, иные от двора \\
\hline Outros da corte, & Сюда на время приезжали, - \\
\hline As mulheres gritaram: hurra! & Кричали женщины: ура! \\
\hline E jogaram suas touquinhas para os ares! & И в воздух чепчики бросали! \\
\hline Fámussov & Фамусов \\
\hline (para si) & (про себя) \\
\hline Em má situação ele me coloca. & Уж втянет он меня в беду. \\
\hline (alto) & (Громко) \\
\hline Serguéi Serguéiitch, eu me vou & Сергей Сергеич, я пойду \\
\hline $\begin{array}{l}\text { E o espero no gabinete. } \\
\text { (sai) }\end{array}$ & $\begin{array}{l}\text { И буду ждать вас в кабинете. } \\
\text { (Уходит.) }\end{array}$ \\
\hline Cena 6 & Явление 6 \\
\hline Skalozúb, Tchátski. & Скалозуб, Чацкий. \\
\hline Skalozúb & Скалозуб \\
\hline Agrada-me, por esta estimativa, & Мне нравится, при этой смете \\
\hline Como o senhor se referiu habilmente & Искусно как коснулись вы \\
\hline $\begin{array}{l}\text { Sobre o prejuízo de Moscou em prol dos } \\
\text { favoritos, }\end{array}$ & Предубеждения Москвы \\
\hline À guarda, aos da guarda, aos oficiais. & $\begin{array}{l}\text { К любимцам, к гвардии, к гвардейским, к } \\
\text { вардионцам; }\end{array}$ \\
\hline Admira-se o bordado de ouro deles como se & Их золоту, шитью дивятся, будто солнцам! \\
\hline
\end{tabular}




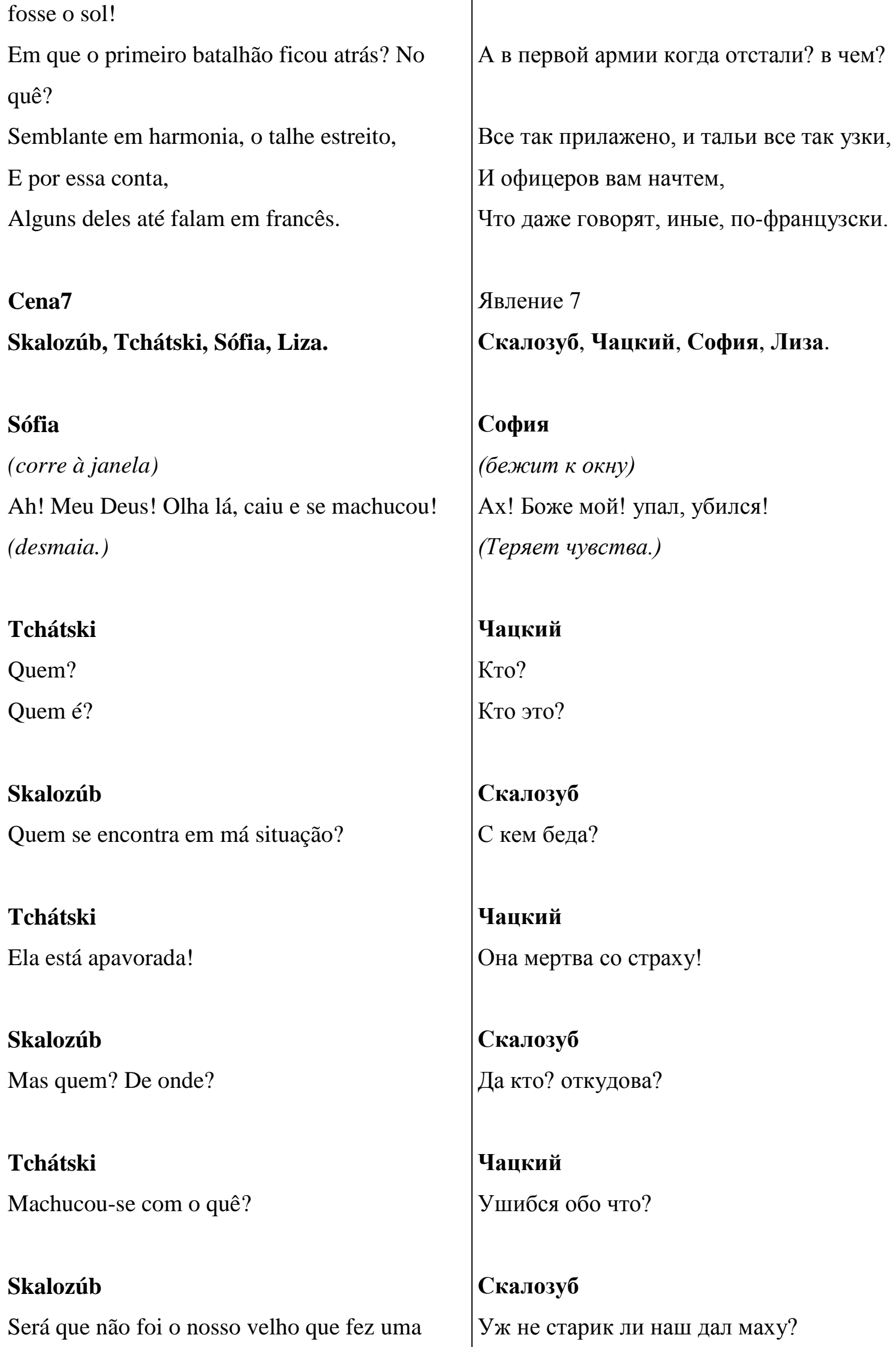

А в первой армии когда отстали? в чем?

Все так прилажено, и тальи все так узки, И офицеров вам начтем,

Что даже говорят, иные, по-французски.

Явление 7

Скалозуб, Чацкий, София, Лиза.

\section{София}

(бежит к окну)

Ах! Боже мой! упал, убился!

(Теряет чувства.)

\section{Чацкий}

Кто?

Кто это?

\section{Скалозуб}

С кем беда?

\section{Чацкий}

Она мертва со страху!

\section{Скалозуб}

Да кто? откудова?

\section{Чацкий}

Ушибся обо что?

\section{Скалозуб}

Уж не старик ли наш дал маху? 


\begin{tabular}{|c|c|}
\hline besteira? & \\
\hline Liza & Лиза \\
\hline (cuida de perto da senhorita) & (хлопочет около барышни) \\
\hline $\begin{array}{l}\text { A quem a senhora aponta, ao destino não } \\
\text { escapa: }\end{array}$ & Кому назначено-с, не миновать судьбы: \\
\hline $\begin{array}{l}\text { Moltchálin se sentou no cavalo, as pernas no } \\
\text { estribo, }\end{array}$ & Молчалин на лошадь садился, ногу в стремя, \\
\hline Mas o cavalo empinou-se, & А лошадь на дыбы, \\
\hline Ele, ambos, caíram com a testa na terra. & Он об землю и прямо в темя. \\
\hline Skalozúb & Скалозуб \\
\hline $\begin{array}{l}\text { Ele deve ter afrouxado as rédeas. Mas que } \\
\text { cavaleiro lamentável! }\end{array}$ & Поводья затянул, ну, жалкий же ездок. \\
\hline $\begin{array}{l}\text { Veja só que golpe - será que foi no peito ou } \\
\text { nos flancos? }\end{array}$ & $\begin{array}{l}\text { Взглянуть, как треснулся он - грудью или в } \\
\text { ок? }\end{array}$ \\
\hline (sai.) & 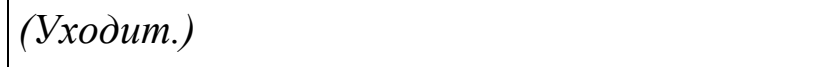 \\
\hline Cena 8 & Явление 8 \\
\hline Os mesmos, sem Skalozúb. & Те же, без Скалозуба. \\
\hline Tchátski & Чацкий \\
\hline Em que posso ajudar? Diga logo. & Помочь ей чем? Скажи скорее. \\
\hline Liza & Лиза \\
\hline Lá no quarto há um copo d'água. & Там в комнате вода стоит. \\
\hline (Tchátski corre e traz o copo. Tudo se segue- & (Чаикий бежит и приносит. Все следующеее - \\
\hline à meia voz-até que Sófia desperta.) & полголоса, - до того, как София очнется.) \\
\hline Encha o copo. & Стакан налейте. \\
\hline Tchátski & Чацкий \\
\hline Já está cheio. & Уж налит. \\
\hline Solte mais o corselete, & Шнуровку отпусти вольнее, \\
\hline
\end{tabular}




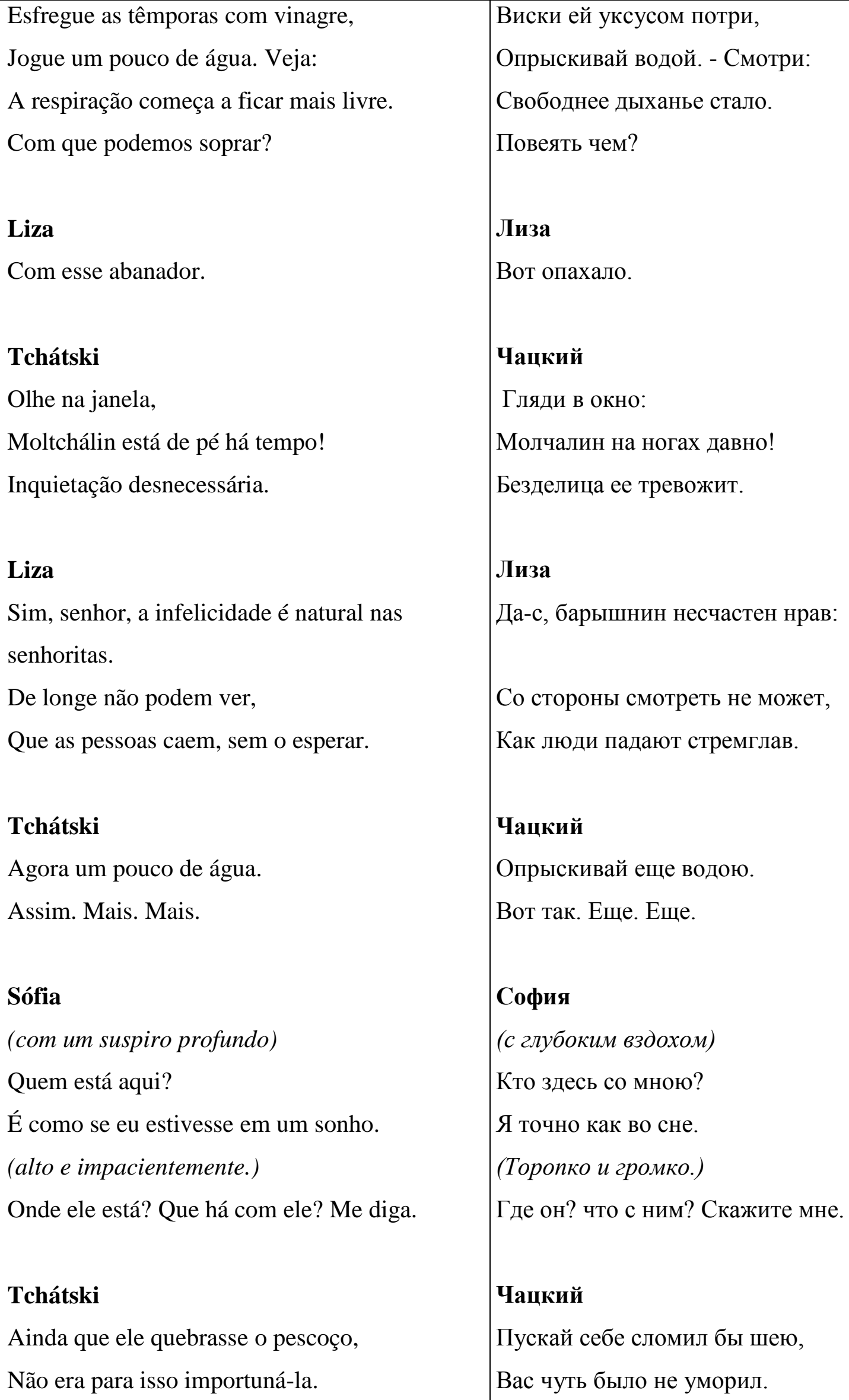

Ainda que ele quebrasse o pescoço, Não era para isso importuná-la.

Виски ей уксусом потри,

Опрыскивай водой. - Смотри:

Свободнее дыханье стало.

Повеять чем?

Лиза

Вот опахало.

\section{Чацкий}

Гляди в окно:

Молчалин на ногах давно!

Безделица ее тревожит.

\section{Лиза}

Да-с, барышнин несчастен нрав:

Со стороны смотреть не может, Как люди падают стремглав.

\section{Чацкий}

Опрыскивай еще водою.

Вот так. Еще. Еще.

\section{София}

(с глубоким вздохом)

Кто здесь со мною?

Я точно как во сне.

(Торопко и громко.)

Где он? что с ним? Скажите мне.

\section{Чацкий}

Пускай себе сломил бы шею, Вас чуть было не уморил. 


\begin{tabular}{|c|c|}
\hline A senhorita não morreu por pouco! & \\
\hline Sófia & София \\
\hline Que frieza mortal essa a sua! & Убийственны холодностью своею! \\
\hline Não aguento mais vê-lo e nem ouvi-lo. & Смотреть на вас, вас слушать нету сил. \\
\hline Tchátski & Чацкий \\
\hline Quer que eu me torture por ele? & Прикажете мне за него терзаться? \\
\hline Sófia & София \\
\hline $\begin{array}{l}\text { Devia correr para lá, para ajudá-lo a se } \\
\text { levantar. }\end{array}$ & Туда бежать, там быть, помочь ему стараться. \\
\hline Tchátski & Чацкий \\
\hline Para que você fique sozinha e sem ajuda? & Чтоб оставались вы без помощи одне? \\
\hline Sófia & София \\
\hline E em que você me ajuda? & На что вы мне? \\
\hline $\begin{array}{l}\text { Sim, é verdade, a desgraça não aconteceu com } \\
\text { você - para você é apenas um passatempo. }\end{array}$ & Да, правда: не свои беды - для вас забавы, \\
\hline Que seja assassinado o pai - tanto faz. & Отец родной убейся - все равно. \\
\hline$(\grave{a} \operatorname{Liza})$ & (Лизе) \\
\hline Vamos lá, e rápido. & Пойдем туда, бежим. \\
\hline Liza & Лиза \\
\hline (afasta-a para o lado) & (отводит ее а сторону) \\
\hline $\begin{array}{l}\text { Olha lá, minha senhora! Onde está com a } \\
\text { cabeça? }\end{array}$ & Опомнитесь! куда вы? \\
\hline $\begin{array}{l}\text { Ele está vivo, com saúde, veja aqui pela } \\
\text { janela. }\end{array}$ & Он жив, здоров, смотрите здесь в окно. \\
\hline Sófia aparece à janelinha. & (София в окошко высовывается.) \\
\hline Tchátski & Чацкий \\
\hline
\end{tabular}




\begin{tabular}{|c|c|}
\hline Que ansiedade! E esse desmaio! Essa pressa! & Смятенье! обморок! поспешность! гнев! \\
\hline Quanta ira! Que susto! & спуга! \\
\hline Assim só é possível se sentir & Так можно только ощущать, \\
\hline Quando se perde um amigo único. & Когда лишаешься единственного друга. \\
\hline Sófia & София \\
\hline $\begin{array}{l}\text { Eles vêm para cá. Ele mal pode levantar os } \\
\text { braços. }\end{array}$ & Сюда идут. Руки не может он поднять. \\
\hline Tchátski & Чацкий \\
\hline Eu desejaria ser morto com ele. & Желал бы с ним убиться... \\
\hline Liza & Лиза \\
\hline Pela companhia? & Для компаньи? \\
\hline Sófia & София \\
\hline Não, não faça isso. & Нет, оставайтесь при желаньи. \\
\hline Cena 9 & Явление 9 \\
\hline $\begin{array}{l}\text { Sófia, Liza, Skalozúb, Moltchálin (com o } \\
\text { braço atado). }\end{array}$ & $\begin{array}{l}\text { София, Лиза, Чацкий, Скалозуб, } \\
\text { Іолчалин (с подвязанною рукою). }\end{array}$ \\
\hline Skalozúb & Скалозуб \\
\hline São e salvo. & Воскрес и невредим, рука \\
\hline O braço está ligeiramente machucado, & Ушиблена слегка, \\
\hline E, de resto, foi tudo alarme falso. & И впрочем, все фальшивая тревога. \\
\hline Moltchálin & Молчалин \\
\hline Eu a assustei, pelo amor de Deus, me perdoe. & Я вас перепугал, простите ради Бога. \\
\hline Skalozúb & Скалозуб \\
\hline Bem, eu não sabia que isso lhe causaria essa & Ну, я не знал, что будет из того \\
\hline
\end{tabular}




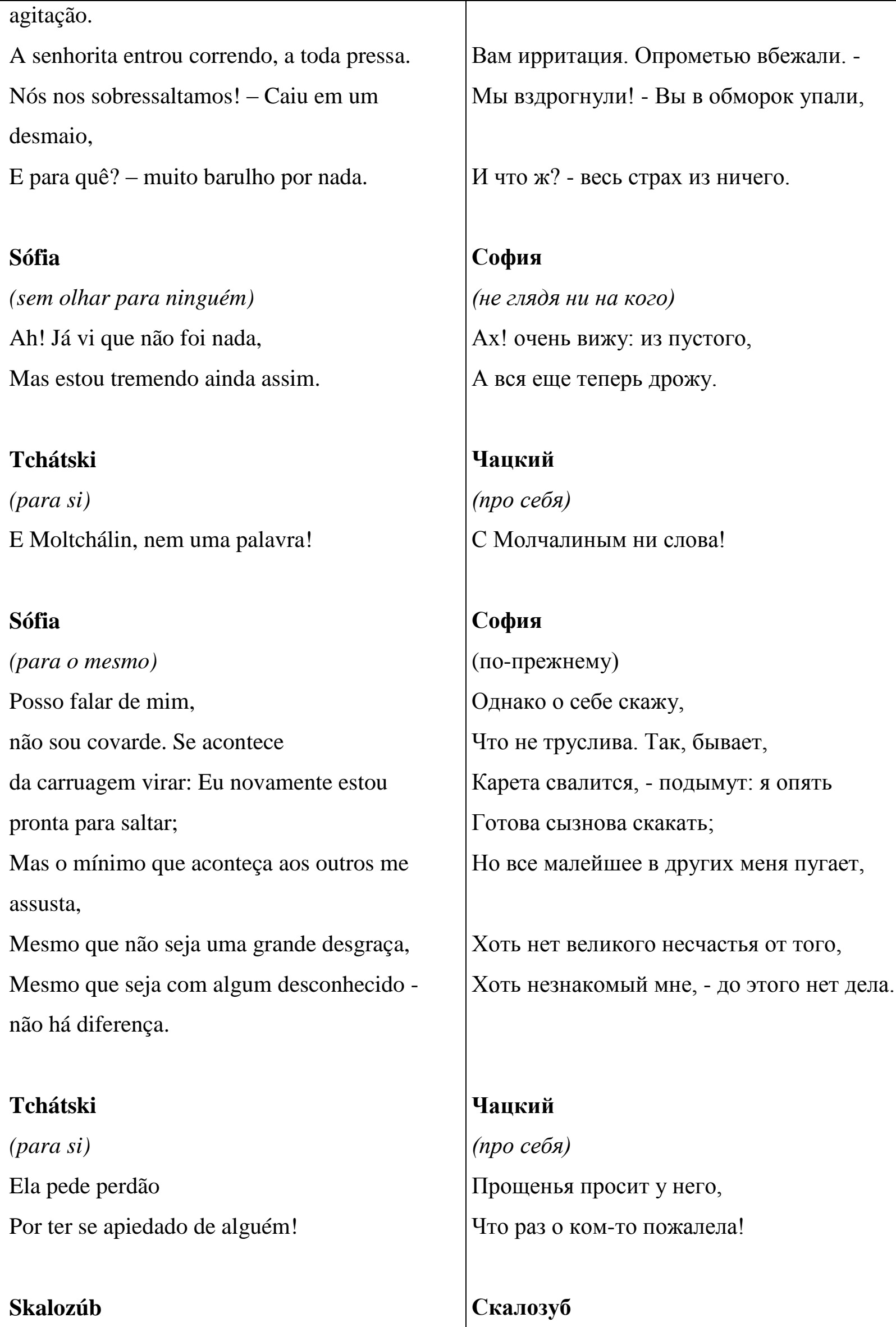

\section{Tchátski}

(para si)

Ela pede perdão

Por ter se apiedado de alguém!

Skalozúb

Вам ирритация. Опрометью вбежали. -

Мы вздрогнули! - Вы в обморок упали,

И что ж? - весь страх из ничего.

\section{София}

(не глядя ни на кого)

Ax! очень вижу: из пустого,

А вся еще теперь дрожу.

\section{Чацкий \\ (про себя) \\ С Молчалиным ни слова!}

\section{София}

(по-прежнему)

Однако о себе скажу,

Что не труслива. Так, бывает,

Карета свалится, - подымут: я опять

Готова сызнова скакать;

Но все малейшее в других меня пугает,

Хоть нет великого несчастья от того,

Хоть незнакомый мне, - до этого нет дела.

\section{Чацкий}

(про себя)

Прощенья просит у него,

Что раз о ком-то пожалела!

\section{Скалозуб}


Permitam-me, vou lhes contar uma história:

Há aqui uma certa princesa Lássova,

Viúva, amazona, mas ao cavalgar,

Não é exemplo para nada.

Nas vezes em que se machucou toda,

Distraído, o jóquei não a amparou,

Como dizem, ela é desajeitada,

Agora as suas costelas fazem falta

E assim ela busca um marido para apoiá-la.

\section{Sófia}

Ah! Aleksandr Andreiitch,

Ora, seja inteiramente generoso:

Quando a desgraça está próxima, não seja indiferente.

\section{Tchátski}

Sim, senhora, fui eu que manifestei

O meu empenho e meu zelo,

Borrifei e esfreguei suas têmporas;

Não sei para quem, mas fui eu que a reavivei.

(pega o chapéu e sai)

\section{Cena 10}

Os mesmos, sem Tchátski.

\section{Sófia}

Virá à noite?

\section{Skalozúb}

Que horas?
Позвольте, расскажу вам весть:

Княгиня Ласова какая-то здесь есть,

Наездница, вдова, но нет примеров,

Чтоб ездило с ней много кавалеров.

На днях расшиблась в пух, -

Жоке не поддержал, считал он, видно, мух. -

без того она, как слышно, неуклюжа,

Теперь ребра недостает,

Так для поддержки ищет мужа.

\section{София}

Ах, Александр Андреич, вот -

Явитесь, вы вполне великодушны:

К несчастью ближнего вы так неравнодушны.

\section{Чацкий}

Да-с, это я сейчас явил

Моим усерднейшим стараньем,

И прысканьем, и оттираньем;

Не знаю для кого, но вас я воскресил!

(Берет шляпу и уходит.)

\section{Явление 10}

Те же, кроме Чацкого.

\section{София}

Вы вечером к нам будете?

\section{Скалозуб}

Как рано? 


\section{Sófia}

O quanto antes: faremos uma reunião para os amigos,

Um pouco de dança ao piano,

Nós estamos de luto, portanto não há como termos baile.

\section{Skalozúb}

Virei, mas agora prometi ter com seu pai.

Despeço-me.

\section{Sófia}

Faça o favor.

\section{Skalozúb}

(aperta a mão de Moltchálin)

Seu criado.

(sai.)

\section{Cena 11}

Sófia, Liza, Moltchálin

\section{Sófia}

Moltchálin! Eu quase perdi completamente o juízo!

Saiba como a sua vida me é estimada!

Para que jogar com a vida de modo tão imprudente?

Me diz, que há com seu braço?

Será que não precisa de remédio?

Será que não necessita de um descanso?

\section{София}

Пораньше; съедутся домашние друзья

Потанцевать под фортопияно, -

Мы в трауре, так балу дать нельзя.

\section{Скалозуб}

Явлюсь, но к батюшке зайти я обещался, Откланяюсь.

\section{София}

Прощайте.

\section{Скалозуб}

(жмет руку Молчалину)

Ваш слуга.

(Уxodum.)

\section{Явление 11}

София, Лиза, Молчалин.

\section{София}

Молчалин! как во мне рассудок цел остался!

Ведь знаете, как жизнь мне ваша дорога! Зачем же ей играть, и так неосторожно?

Скажите, что у вас с рукой?

Не дать ли капель вам? не нужен ли покой? Пошлемте к доктору, пренебрегать не 


\begin{tabular}{|c|c|}
\hline $\begin{array}{l}\text { Eu vou mandar vir o médico, não podemos } \\
\text { deixar como está. }\end{array}$ & олжно. \\
\hline Moltchálin & Молчалин \\
\hline $\begin{array}{l}\text { Está atado com um lenço, por enquanto não } \\
\text { está doendo. }\end{array}$ & Платком перевязал, не больно мне с тех пор. \\
\hline Liza & Лиза \\
\hline Eu juro que isso tudo é uma tolice, & Ударюсь об заклад, что вздор; \\
\hline $\begin{array}{l}\text { Se o machucado não é visível não é } \\
\text { necessário curativo; }\end{array}$ & И если б не к лицу, не нужно перевязки; \\
\hline $\begin{array}{l}\text { Mas o que não seria tolice alguma é evitar que } \\
\text { se espalhe: }\end{array}$ & А то не вздор, что вам не избежать огласки: \\
\hline Logo mais, Tchátski cairá no riso & На смех, того гляди, подымет Чацкий вас; \\
\hline E Skalozúb, com suas firulas, & И Скалозуб, как свой хохол закрутит, \\
\hline Falará do desmaio, adicionando cem figuras; & Расскажет обморок, прибавит сто прикрас; \\
\hline Por zombaria, mas ele é capaz de tudo, pois & Шутить и он горазд, ведь нынче кто не \\
\hline hoje em dia quem é que não zomba?! & 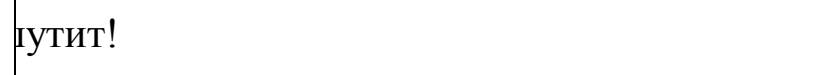 \\
\hline Sófia & София \\
\hline Qual deles me é mais caro? & А кем из них я дорожу? \\
\hline Quero - amo, quero - falo. & Хочу - люблю, хочу - скажу. \\
\hline Moltchálin, e se eu não o obrigasse? & Молчалин! будто я себя не принуждала? \\
\hline Você entrou, sem nenhuma palavra, & Вошли вы, слова не сказала, \\
\hline Eu não ousaria respirar por eles, & При них не смела я дохнуть, \\
\hline Se tiver pedidos, é só a você que atendo. & У вас спросить, на вас взглянуть. \\
\hline Moltchálin & Молчалин \\
\hline Não, Sófia Pávlovna, você foi sincera demais. & Нет, Софья Павловна, вы слишком кровенны. \\
\hline Sófia & София \\
\hline Como é que vou conseguir dissimular? & Откуда скрытность почерпнуть! \\
\hline À janelinha, eu estava pronta para saltar até & Готова я была в окошко, к вам прыгнуть. \\
\hline
\end{tabular}




\begin{tabular}{|c|c|}
\hline você, & \\
\hline $\begin{array}{l}\text { E o que eu devo a quem quer que seja? A } \\
\text { eles? Ao mundo todo? }\end{array}$ & $\begin{array}{l}\text { Да что мне до кого? до них? до всей } \\
\text { селенны? }\end{array}$ \\
\hline $\begin{array}{l}\text { É ridículo? - deixe que eles zombem; é de } \\
\text { lastimar? - deixe que reprovem. }\end{array}$ & $\begin{array}{l}\text { Смешно? - пусть шутят их; досадно? - пусть } \\
\text { ранят. }\end{array}$ \\
\hline Moltchálin & Молчалин \\
\hline Esta sinceridade não nos prejudicaria. & Не повредила бы нам откровенность эта. \\
\hline Sófia & София \\
\hline $\begin{array}{l}\text { Será que tem vontade de chamá-lo a um } \\
\text { duelo? }\end{array}$ & $\begin{array}{l}\text { Неужто на дуэль вас вызвать } \\
\text { захотят? }\end{array}$ \\
\hline Moltchálin & Молчалин \\
\hline $\begin{array}{l}\text { Ah! As más línguas são mais terríveis que as } \\
\text { pistolas. }\end{array}$ & Ах! злые языки страшнее пистолета. \\
\hline Liza & Лиза \\
\hline Eles estão agora com o paizinho, & Сидят они у батюшки теперь, \\
\hline Se a senhora borboletear pela porta & Вот кабы вы порхнули в дверь \\
\hline Com o rosto alegre, despreocupada: & С лицом веселым, беззаботно: \\
\hline Será mais fácil de acreditar & Когда нам скажут, что хотим - \\
\hline Quando nos disserem o que queremos. & Куда как верится охотно! \\
\hline $\begin{array}{l}\text { E quanto a Aleksandr Andréiitch - fale com } \\
\text { ele }\end{array}$ & И Александр Андреич, - с ним \\
\hline $\begin{array}{l}\text { Sobre os tempos passados, sobre aquelas } \\
\text { travessuras. }\end{array}$ & О прежних днях, о тех проказах \\
\hline $\begin{array}{l}\text { Vai explorar seu talento como contadora de } \\
\text { histórias: }\end{array}$ & Поразвернитесь-ка в рассказах: \\
\hline Uns risinhos e umas palavrinhas, & Улыбочка и пара слов, \\
\hline Pois quem ama, para tudo está pronto. & И кто влюблен - на все готов. \\
\hline Moltchálin & Молчалин \\
\hline
\end{tabular}




\begin{tabular}{|c|c|}
\hline $\begin{array}{l}\text { Eu não me atrevo a lhe aconselhar. } \\
\text { (beija a mão dela.) }\end{array}$ & $\begin{array}{l}\text { Я вам советовать не смею. } \\
\text { (Целует ей руку.) }\end{array}$ \\
\hline Sófia & София \\
\hline $\begin{array}{l}\text { É isso que quer? Irei galantear mediante as } \\
\text { lágrimas; }\end{array}$ & Хотите вы?.. Пойду любезничать сквозь слез; \\
\hline Temo que não saiba manter o fingimento. & Боюсь, что выдержать притворства не сумею. \\
\hline Para que Deus foi trazer Tchátski aqui! & Зачем сюда Бог Чацкого принес! \\
\hline (sai.) & (Уxодит.) \\
\hline Cena 12 & Явление 12 \\
\hline Moltchálin, Liza & Молчалин, Лиза \\
\hline Moltchálin & Молчалин \\
\hline Que gracinha você é! Tão viva! & Веселое созданье ты! живое! \\
\hline Liza & Лиза \\
\hline Me deixe em paz, o senhor já tem dona. & Прошу пустить, и без меня вас двое. \\
\hline Moltchálin & Молчалин \\
\hline Que carinha você tem! & Какое личико твое! \\
\hline Como eu te amo! & Как я тебя люблю! \\
\hline Liza & Лиза \\
\hline Mas e a senhorita? & А барышню? \\
\hline Moltchálin & Молчалин \\
\hline Ela, & $\mathrm{Ee}$ \\
\hline Pelo dever, você... & По должности, тебя... \\
\hline (quer abraçá-la.) & (Хочет ее обнять.) \\
\hline
\end{tabular}




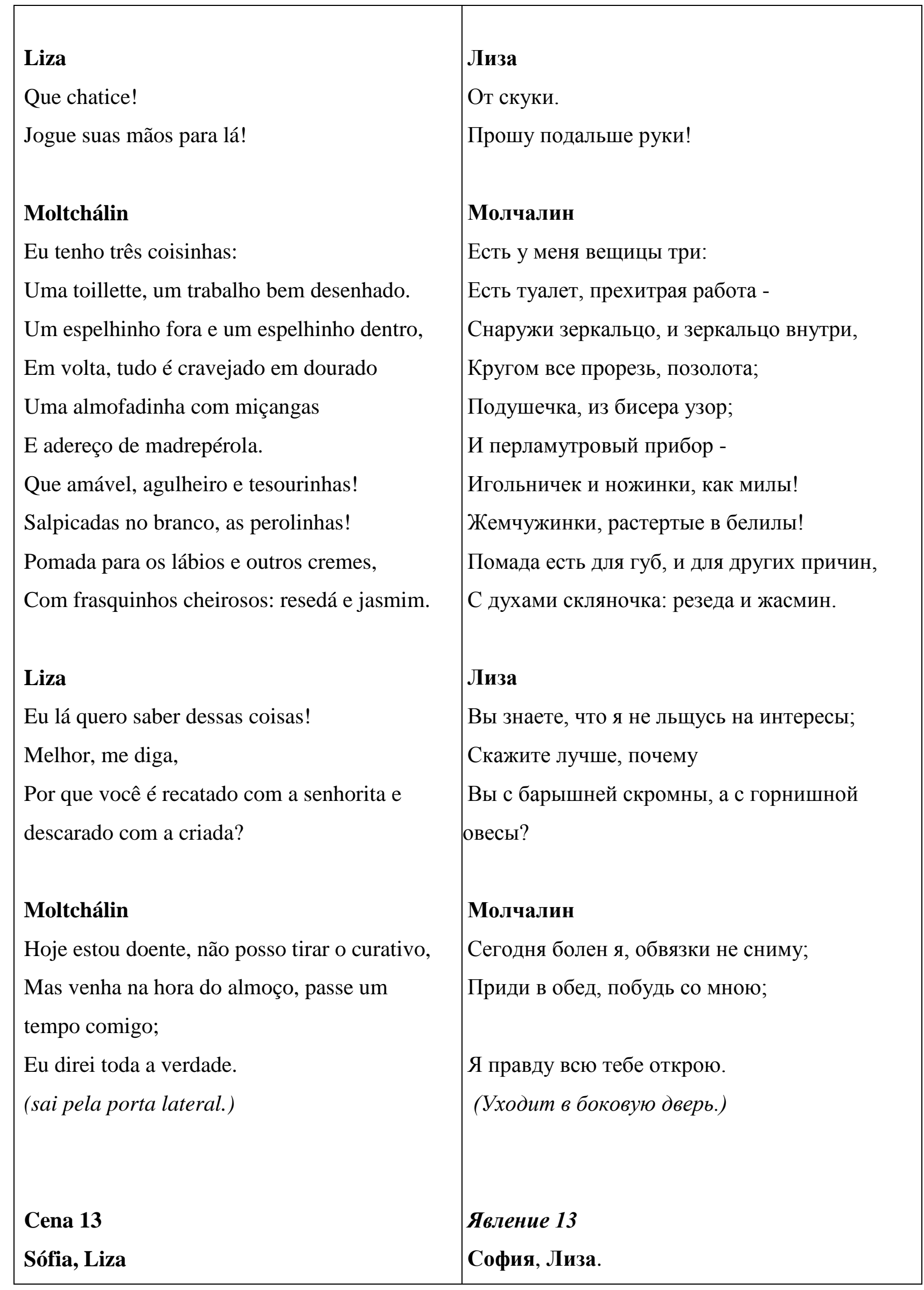




\section{Sófia}

Estive na sala do paizinho, não havia ninguém lá.

Hoje estou doente e não irei almoçar.

Convide Moltchálin, diga a ele que venha me visitar.

(vai para seu quarto)

\section{Cena 14}

\section{Liza}

Ora essa! Que gente é essa aqui!

Ela o quer e ele me quer,

E eu... Só eu temo o amor até a morteMas como não se apaixonar pelo criado Pietrúcha!

\section{Fim do Ato II.}

\section{София}

Была у батюшки, там нету никого.

Сегодня я больна, и не пойду обедать, Скажи Молчалину, и позови его, Чтоб он пришел меня проведать. (Уходит к себе.)

\section{Явление 14}

Лиза

Ну! люди в здешней стороне!

Она к нему, а он ко мне,

А я... одна лишь я любви до смерти трушу, А как не полюбить буфетчика Петрушу!

Конец II действия. 


\begin{tabular}{|c|c|}
\hline ATO III & ДЕЙСТВИЕ III \\
\hline Cena 1 & Явление 1 \\
\hline Tchátski, depois Sófia. & Чацкий, потом София. \\
\hline Tchátski & Чацкий \\
\hline Eu vou esperá-la, vou forçar uma confissão ${ }^{111}$ : & Дождусь ее, и вынужу признанье: \\
\hline Afinal, quem lhe é mais caro? Moltchálin! & Кто наконец ей мил? Молчалин! Скалозуб! \\
\hline Skalozúb! & \\
\hline O Moltchálin de antes era um paspalhão!.. & Молчалин прежде был так глуп!.. \\
\hline Uma criatura que dá pena! & Жалчайшее созданье! \\
\hline Será que ficou mais inteligente?... Já o outro - & Уж разве поумнел?.. А тот - \\
\hline De voz estertorante, esganada, um fagote, & Хрипун, удавленник, фагот, \\
\hline Uma constelação de estratagemas e mazurcas! & Созвездие маневров и мазурки! \\
\hline Eis o destino do amor: brincar de cabra-cega, & Судьба любви - играть ей в жмурки. \\
\hline Quanto a mim... & А мне... \\
\hline Entra Sófia. & (Входит София.) \\
\hline A senhorita, aqui? Eu estou muito contente. & Вы здесь? я очень рад, \\
\hline Eu ansiava por isso. & Я этого желал. \\
\hline Sófia & София \\
\hline (para si) & (про себя) \\
\hline E muito fora de propósito. & И очень невпопад. \\
\hline Tchátski & Чацкий \\
\hline Certamente não me procurava. & Конечно, не меня искали? \\
\hline Sófia & София \\
\hline Sim, eu não o procurava. & Я не искала вас. \\
\hline
\end{tabular}




\section{Tchátski}

Será que eu poderia saber

Ainda que fora de propósito, não importa:

Quem você ama?

\section{Sófia}

Ah! Meu Deus! Todo o mundo.

\section{Tchátski}

Quem lhe é mais caro?

\section{Sófia}

Há muitos, os parentes.

\section{Tchátski}

Todos mais do que eu?

\section{Sófia}

Alguns.

\section{Tchátski}

E o que hei de querer, quando tudo estiver decidido?

Estou preso na forca, enquanto para ela, é ridículo.

\section{Sófia}

Será que quer saber da verdade em poucas palavras?

Quanto menor for a singularidade, mais é visível,

A sua alegria não é discreta,

\section{Чацкий}

Дознаться мне нельзя ли,

Хоть и некстати, нужды нет:

Кого вы любите?

\section{София}

Ах! Боже мой! весь свет.

\section{Чаџкий}

Кто более вам мил?

\section{София}

Есть многие, родные.

\section{Чацкий}

Все более меня?

\section{София}

Иные.

\section{Чацкий}

И я чего хочу, когда все решено?

Мне в петлю лезть, а ей смешно.

\section{София}

Хотите ли знать истины два слова?

Малейшая в ком странность чуть видна,

Веселость ваша не скромна, 


\begin{tabular}{|c|c|}
\hline $\begin{array}{l}\text { No mesmo instante, você já tem pronta uma } \\
\text { pilhéria, }\end{array}$ & У вас тотчас уж острота готова, \\
\hline Enquanto você mesmo... & А сами вы... \\
\hline Tchátski & Чацкий \\
\hline $\begin{array}{l}\text { Eu mesmo? Será que não é verdade que me } \\
\text { acha ridículo? }\end{array}$ & Я сам? не правда ли, смешон? \\
\hline Sófia & София \\
\hline Sim! Um olhar terrível, um tom cortante. & Да! грозный взгляд, и резкий тон, \\
\hline $\begin{array}{l}\text { Em você, tudo isso é um abismo de } \\
\text { peculiaridades; }\end{array}$ & И этих в вас особенностей бездна; \\
\hline $\begin{array}{l}\text { Seria muito útil que fosse severo também } \\
\text { consigo. }\end{array}$ & А над собой гроза куда не бесполезна. \\
\hline Tchátski & Чацкий \\
\hline Eu sou estranho, mas quem não é? & Я странен, а не странен кто ж? \\
\hline $\begin{array}{l}\text { Aquele que se assemelha a todo e qualquer } \\
\text { tolo; }\end{array}$ & Тот, кто на всех глупцов похож; \\
\hline Moltchálin, por exemplo... & Молчалин, например... \\
\hline Sófia & София \\
\hline Exemplos não dizem nada; & Примеры мне не новы; \\
\hline $\begin{array}{l}\text { Você está pronto para destilar seu veneno em } \\
\text { todos, }\end{array}$ & Заметно, что вы желчь на всех излить готовы; \\
\hline $\begin{array}{l}\text { Mas eu, para que não me atrapalhe, vou é sair } \\
\text { daqui. }\end{array}$ & А я, чтоб не мешать, отсюда уклонюсь. \\
\hline Tchátski & Чацкий \\
\hline (segurando-a) & (держит ее) \\
\hline Espere então! & Постойте же. \\
\hline (de lado.) & (В сторону) \\
\hline $\mathrm{Eu}$ vou fingir pela primeira vez na vida. & Раз в жизни притворюсь. \\
\hline
\end{tabular}




\begin{tabular}{|c|c|}
\hline (Alto.) & $($ (Громко) \\
\hline Vamos deixar estas discussões para lá, & Оставимте мы эти пренья. \\
\hline Não fui correto com Moltchálin, sou culpado; & Перед Молчалиным не прав я, виноват; \\
\hline Talvez ele não seja o que era há três anos: & Быть может он не то, что три года назад: \\
\hline Na terra, há tantas mudanças, & Есть на земле такие превращенья \\
\hline $\begin{array}{l}\text { De governo, de clima, de costumes, de } \\
\text { pensamentos; }\end{array}$ & Правлений, климатов, и нравов, и умов, \\
\hline $\begin{array}{l}\text { Há pessoas importantes que tem a reputação } \\
\text { de tolos: }\end{array}$ & Есть люди важные, слыли за дураков: \\
\hline $\begin{array}{l}\text { Alguns estão no exército, outros são péssimos } \\
\text { poetas }\end{array}$ & Иной по армии, иной плохим поэтом, \\
\hline $\begin{array}{l}\text { E outros... Temo denominá-los, mas são } \\
\text { aceitos em todo o mundo, }\end{array}$ & $\begin{array}{l}\text { Иной... Боюсь назвать, но признано всем } \\
\text { ветом, }\end{array}$ \\
\hline E ficaram muito sábios & Особенно в последние года, \\
\hline de uns anos para cá. & Что стали умны хоть куда. \\
\hline Suponhamos que em Moltchálin haja uma & Пускай в Молчалине ум бойкий, гений \\
\hline inteligência viva, um gênio valoroso, & мелый, \\
\hline Mas será que nele há paixão? Sentimento? & Но есть ли в нем та страсть? то чувство? \\
\hline Impetuosidade? & ылкость та? \\
\hline Que sem você, & Чтоб, кроме вас, ему мир целый \\
\hline tudo é vaidade? ${ }^{\mathrm{mmm}}$; & Казался прах и суета? \\
\hline Que cada batimento do coração acelera de & Чтоб сердца каждое биенье \\
\hline amor por você? & Любовью ускорялось к вам? \\
\hline Que todos os seus pensamentos giram todos & Чтоб мыслям были всем, и всем его делам \\
\hline $\begin{array}{l}\text { em torno de assuntos da alma - Isso lhe } \\
\text { contenta? }\end{array}$ & Душою - вы, вам угожденье?.. \\
\hline Eu mesmo sinto que não posso falar; & Сам это чувствую, сказать я не могу, \\
\hline $\begin{array}{l}\text { Mas tudo agora ferve, me revolta e me } \\
\text { consome, }\end{array}$ & Но что теперь во мне кипит, волнует, бесит, \\
\hline $\begin{array}{l}\text { Eu não esperava por um inimigo em } \\
\text { particular, }\end{array}$ & Не пожелал бы я и личному врагу, \\
\hline Mas ele?... Guarda silêncio e se resigna. & А он?.. смолчит и голову повесит. \\
\hline Claro, é submisso, todos os que são assim não & Конечно, смирен, все такие не резвы; \\
\hline
\end{tabular}


são espirituosos;

Deus sabe que nele há um certo mistério dissimulado;

Deus sabe o que você imagina sobre ele,

Porque a cabeça dele nunca esteve lá muito atulhada.

Talvez suas qualidades sejam muitas, E ao admirá-lo, você atribui tudo a ele.

Ele não é nem pecador naquilo que você é, cem vezes, mais pecadora.

Não! Não! Suponhamos que ele seja sábio E que vá ficar mais sábio a cada instante, Será que ele é digno de você? - Eis uma pergunta.

Sofrerá uma grande perda sendo tão indiferente a mim,

Um ser humano como você, que cresceu ao seu lado,

Como um amigo, como um irmão,

Convença-me disso;

Depois,

Até a loucura eu consigo evitar;

Eu vou partir para esfriar, vou perder o interesse,

Não pensar em amor, mas eu vou ter de me perder para o mundo, esquecer-me de tudo e cair na diversão.

\section{Sófia}

(para si)

Olha só, eu o fiz perder a cabeça!

(em voz,alta)

Para que disfarçar?
Бог знает, в нем какая тайна скрыта;

Бог знает, за него что выдумали вы, Чем голова его ввек не была набита.

Быть может, качеств ваших тьму, Любуясь им, вы придали ему;

Не грешен он ни в чем, вы во сто раз решнее.

Нет! нет! пускай умен, час от часу умнее,

Но вас он стоит ли? вот вам один вопрос.

Чтоб равнодушнее мне понести утрату,

Как человеку вы, который с вами взрос,

Как другу вашему, как брату,

Мне дайте убедиться в том;

Потом

От сумасшествия могу я остеречься;

Пушусь подалее простыть, охолодеть.

Не думать о любви, но буду я уметь

Теряться по свету, забыться и развлечься.

\section{София}

(про себя)

Вот нехотя с ума свела!

(Вслух)

Что притворяться? 


\begin{tabular}{|c|c|}
\hline $\begin{array}{l}\text { Há pouco, Moltchálin quase ficou sem os } \\
\text { braços, }\end{array}$ & Молчалин давиче мог без руки остаться, \\
\hline Eu me exaltei e fui solidária a ele; & Я живо в нем участье приняла; \\
\hline $\begin{array}{l}\text { Mas estando aqui por acaso naquele } \\
\text { momento, }\end{array}$ & А вы, случась на эту пору, \\
\hline Você não se ocupou em pensar & Не позаботились расчесть, \\
\hline Que é possível ser bom com todos & Что можно доброй быть ко всем и без \\
\hline indistintamente; & азбору; \\
\hline $\begin{array}{l}\text { Mas talvez haja uma verdade em suas } \\
\text { suposições, }\end{array}$ & Но может истина в догадках ваших есть, \\
\hline $\begin{array}{l}\text { E, entusiasmada, eu vá mesmo correr em sua } \\
\text { defesa. }\end{array}$ & И горячо его беру я под защиту; \\
\hline Eu lhe pergunto sem rodeios, para que essa & Зачем же быть, скажу вам напрямик, \\
\hline língua solta? & Так невоздержну на язык? \\
\hline Tão aberta assim por desprezo às pessoas? & В презреньи к людям так нескрыту? \\
\hline $\begin{array}{l}\text { Para quem subjuga não há clemência!... Do } \\
\text { quê? }\end{array}$ & Что и смирнейшему пощады нет!.. чего? \\
\hline Quando acontece de alguém o chamar: & Случись кому назвать его: \\
\hline Lá vem uma saraivada de troças e sarcasmos! & Град колкостей и шуток ваших грянет. \\
\hline $\begin{array}{l}\text { Zombar! Sempre a zombar! Você deveria se } \\
\text { envergonhar! }\end{array}$ & Шутить! и век шутить! как вас на это станет! \\
\hline Tchátski & Чацкий \\
\hline Ah! Meu Deus! Será possível que somente eu, & Ах! Боже мой! неужли я из тех, \\
\hline $\begin{array}{l}\text { De todos os que existem por aí - só eu me } \\
\text { divirto? }\end{array}$ & Которым цель всей жизни - смех? \\
\hline $\begin{array}{l}\text { Sinto-me alegre quando encontro pessoas } \\
\text { ridículas, }\end{array}$ & Мне весело, когда смешных встречаю, \\
\hline $\begin{array}{l}\text { Mas, a maior parte do tempo, eu me entedio } \\
\text { com elas. }\end{array}$ & А чаще с ними я скучаю. \\
\hline Sófia & София \\
\hline É inútil: isso são os outros, & Напрасно: это все относится к другим, \\
\hline
\end{tabular}




\begin{tabular}{|c|c|}
\hline Moltchálin pouco o entediaria, & Молчалин вам наскучил бы едва ли, \\
\hline Se fizesse amizade com ele. & Когда б сошлись короче с ним. \\
\hline $\begin{array}{l}\text { Tchátski } \\
\text { (com entusiasmo) }\end{array}$ & $\begin{array}{l}\text { Чацкий } \\
\text { (с жаром) }\end{array}$ \\
\hline $\begin{array}{l}\text { Mas como é que foi conhecê-lo tão } \\
\text { intimamente? }\end{array}$ & Зачем же вы его так коротко узнали? \\
\hline Sófia & София \\
\hline Eu não me esforcei para tal, Deus nos uniu. & Я не старалась, Бог нас свел. \\
\hline Ele ganhou a amizade de todos em casa: & Смотрите, дружбу всех он в доме приобрел; \\
\hline Há três anos serve ao paizinho, & При батюшке три года служит, \\
\hline Que quase sempre se zanga sem motivo, & Тот часто без толку сердит, \\
\hline Mas ele o desarma com o silêncio, & А он безмолвием его обезоружит, \\
\hline E perdoa, pela bondade de sua alma. & От доброты души простит. \\
\hline Enquanto isso, nós saímos em busca & И, между прочим, \\
\hline De passatempos. & Веселостей искать бы мог; \\
\hline Mas não ele: nunca se afasta dos mais velhos. & Ничуть: от старичков не ступит за порог; \\
\hline Nós brincamos, gargalhamos; & Мы резвимся, хохочем, \\
\hline $\begin{array}{l}\text { Ele fica com eles o dia todo, por bem ou por } \\
\text { mal, }\end{array}$ & Он с ними целый день засядет, рад не рад, \\
\hline Jogando cartas... & Играет... \\
\hline Tchátski & Чацкий \\
\hline Jogando o dia todo! & Целый день играет! \\
\hline Ele se cala quando ralham com ele! & Молчит, когда его бранят! \\
\hline (de lado) & (В сторону) \\
\hline Ela não o estima. & Она его не уважает. \\
\hline Sófia & София \\
\hline É claro, não há nele esta inteligência, & Конечно нет в нем этого ума, \\
\hline $\begin{array}{l}\text { Que é Gênio para uns, mas uma grande } \\
\text { desgraça para outros, }\end{array}$ & Что гений для иных, а для иных чума, \\
\hline
\end{tabular}


Que tão rápido brilha quanto causa repulsa,

Que critica ferozmente a sociedade,

Para que a sociedade fale ainda que qualquer coisa sobre ele;

Será que um espírito inteligente assim pode trazer felicidade a uma família?

\section{Tchátski}

Sátira e moral - todo o pensamento está nisso?

(de lado)

Ele não vale um tostão.

\section{Sófia}

Ele tem, enfim, uma característica milagrosa:

Facilmente cede, é modesto e silencioso.

Em seu rosto não há o menor sinal de inquietação,

Sua alma está livre de quaisquer falhas, Ele não condena os outros injustamente Aí está o porquê eu o amo.

\section{Tchátski}

(de lado)

É uma brincadeira, ela não o ama.

(mais alto)

Eu darei um acabamento a este retrato de Moltchálin.

Mas e Skalozúb? Eis um primor:

O grande defensor de tudo que é exército E permanece com retidão,

Com o rosto e a voz de um herói...
Который скор, блестящ и скоро опротивит, Который свет ругает наповал,

Чтоб свет об нем хоть что-нибудь сказал;

Да эдакий ли ум семейство осчастливит?

\section{Чацкий}

Сатира и мораль - смысл этого всего?

(В сторону)

Она не ставит в грош его.

\section{София}

Чудеснейшего свойства

Он наконец: уступчив, скромен, тих.

В лице ни тени беспокойства,

И на душе проступков никаких, Чужих и вкривь и вкось не рубит, Вот я за что его люблю.

\section{Чацкий}

(в сторону)

Шалит, она его не любит.

(Вслух)

Докончить я вам пособлю

Молчалина изображенье.

Но Скалозуб? вот загляденье;

За армию стоит горой,

И прямизною стана,

Лицом и голосом герой... 


\begin{tabular}{|c|c|}
\hline Sófia & София \\
\hline Herói de um romance que não é o meu. & Не моего романа. \\
\hline Tchástki & Чацкий \\
\hline Não é? Quem poderá decifrá-la? & Не вашего? кто разгадает вас? \\
\hline Cena 2 & Явление 2 \\
\hline Tchátski, Sófia, Liza. & Чацкий, София, Лиза. \\
\hline Liza & Лиза \\
\hline (aos sussurros) & (шепотом) \\
\hline $\begin{array}{l}\text { Senhores, Aleksei Stiepánitch está logo aqui } \\
\text { atrás }\end{array}$ & Сударыня, за мной сейчас \\
\hline Para vê-la, agora. & К вам Алексей Степаныч будет. \\
\hline Sófia & София \\
\hline Por favor, eu tenho de sair o quanto antes. & Простите, надобно идти мне поскорей. \\
\hline Tchátski & Чацкий \\
\hline Para onde? & Куда? \\
\hline Sófia & София \\
\hline Ao coiffeur. & К прихмахеру. \\
\hline Tchátki & Чацкий \\
\hline Que Deus esteja com ele. & Бог с ним. \\
\hline Sófia & София \\
\hline As pinças vão esfriar. & Щипцы простудит. \\
\hline Tchátski & Чацкий \\
\hline
\end{tabular}




\begin{tabular}{|c|c|}
\hline Não se importe, deixe que eles... & Пускай себе... \\
\hline Sófia & София \\
\hline $\begin{array}{l}\text { É impossível, nós aguardamos convidados à } \\
\text { noite. }\end{array}$ & Нельзя, ждем на вечер гостей. \\
\hline Tchátski & Чацкий \\
\hline $\begin{array}{l}\text { Deus esteja convosco, fico novamente com } \\
\text { meu mistério. }\end{array}$ & Бог с вами, остаюсь опять с моей загадкой. \\
\hline No entanto, deixe-me dar uma volta contigo & Однако дайте мне зайти, хотя украдкой, \\
\hline Pelo quarto, por alguns minutos, & К вам в комнату на несколько минут; \\
\hline Ainda que seja às escondidas; & Там стены, воздух - все приятно! \\
\hline Lá há paredes, ar - tudo é agradável!.. & Согреют, оживят, мне отдохнуть дадут \\
\hline $\begin{array}{l}\text { As lembranças daqueles tempos que não } \\
\text { voltam mais me descansam, confortam e } \\
\text { reanimam! }\end{array}$ & Воспоминания об том, что невозвратно! \\
\hline $\begin{array}{l}\text { Não vou me demorar, vamos entrar só por uns } \\
\text { dois minutos, }\end{array}$ & Не засижусь, войду, всего минуты две, \\
\hline $\begin{array}{l}\text { Depois, imagine, sou membro do Clube } \\
\text { Inglês, }\end{array}$ & Потом, подумайте, член Английского клуба, \\
\hline $\begin{array}{l}\text { Eu hei de demorar muito em espalhar os } \\
\text { boatos por lá, }\end{array}$ & Я там дни целые пожертвую молве \\
\hline $\begin{array}{l}\text { Pela inteligência de Moltchálin, pela alma de } \\
\text { Skalozúb. }\end{array}$ & Про ум Молчалина, про душу Скалозуба. \\
\hline $\begin{array}{l}\text { Sófia dá de ombros, vai para o quarto e } \\
\text { trancam-se, ela e Liza. }\end{array}$ & $\begin{array}{l}\text { (София пожимает плечами, уходит к себе и } \\
\text { апирается, за нею и Лиза.) }\end{array}$ \\
\hline Cena 3 & Явление 3 \\
\hline Tchátski, depois Moltchálin. & Чацкий, потом Молчалин. \\
\hline Tchátski & Чацкий \\
\hline $\begin{array}{l}\text { Ah! Sófia! Terá ela escolhido mesmo } \\
\text { Moltchálin! }\end{array}$ & Ах! Софья! Неужли Молчалин избран ей! \\
\hline
\end{tabular}




\begin{tabular}{|c|c|}
\hline E por que não teria qualidades para marido? & А чем не муж? Ума в нем только мало; \\
\hline A inteligência nele é exclusivamente pequena, & \\
\hline Mas para ter filhos, & Но чтоб иметь детей, \\
\hline A quem a inteligência faz falta? & Кому ума недоставало? \\
\hline É prestimoso, muito simples, as faces coradas. & $\begin{array}{l}\text { Услужлив, скромненький, в лице румянец } \\
\text { сть. }\end{array}$ \\
\hline Entra Moltchálin. & (Входит Молчалин.) \\
\hline $\begin{array}{l}\text { Lá vem ele, de mansinho, sem muitas } \\
\text { palavras: }\end{array}$ & Вон он на цыпочках, и не богат словами; \\
\hline Que feitiço ele jogou em seu coração! & Какою ворожбой умел к ней в сердце влезть! \\
\hline (Gira em torno dele) & (Обращиается к нему.) \\
\hline Aleksei Stepánitch, nós ainda não & Нам, Алексей Степаныч, с вами \\
\hline conseguimos trocar nem duas palavras. & Не удалось сказать двух слов. \\
\hline Então, que tipo de vida é a sua? & Ну, образ жизни ваш каков? \\
\hline Agora sem desgraça? Sem tristeza? & Без горя нынче? без печали? \\
\hline Moltchálin & Молчалин \\
\hline Como sempre, senhor. & По-прежнему-с. \\
\hline Tchátski & Чацкий \\
\hline E como vivia antes? & А прежде как живали? \\
\hline Moltchálin & Молчалин \\
\hline Dia após dia, hoje tal como ontem. & День за день, нынче, как вчера. \\
\hline Tchátski & Чацкий \\
\hline $\begin{array}{l}\text { Do trabalho às cartas? E das cartas ao } \\
\text { trabalho? }\end{array}$ & К перу от карт? и к картам от пера? \\
\hline $\begin{array}{l}\text { Uma hora certa para o trabalho e para o } \\
\text { prazer? }\end{array}$ & И положенный час приливам и отливам? \\
\hline Moltchálin & Молчалин \\
\hline Sou forte no trabalho na medida certa, & По мере я трудов и сил, \\
\hline
\end{tabular}




\begin{tabular}{|c|c|}
\hline Desde que iniciei meus serviços nos arquivos, & С тех пор, как числюсь по Архивам, * \\
\hline Recebi três condecorações. & Три награжденья получил. \\
\hline Tchátski & Чацкий \\
\hline Conquistou honras e nobreza? & Взманили почести и знатность? \\
\hline Moltchálin & Молчалин \\
\hline Não, senhor, todos tem seu talento... & Нет-с, свой талант у всех... \\
\hline Tchátski & Чацкий \\
\hline Você tem? & У вас? \\
\hline Moltchálin & Молчалин \\
\hline Tenho dois, senhor: & Два-с: \\
\hline Moderação e pontualidade. & Умеренность и аккуратность. \\
\hline Tchátski & Чацкий \\
\hline $\begin{array}{l}\text { E que dois milagrosos talentos! Está acima de } \\
\text { nós todos. }\end{array}$ & Чудеснейшие два! и стоят наших всех. \\
\hline Moltchálin & Молчалин \\
\hline $\begin{array}{l}\text { O senhor não foi promovido, fracassou no } \\
\text { serviço? }\end{array}$ & Вам не дались чины, по службе неуспех? \\
\hline Tchátski & Чацкий \\
\hline Promovem-se as pessoas, & Чины людьми даются, \\
\hline Mas as pessoas podem se enganar. & А люди могут обмануться. \\
\hline Moltchálin & Молчалин \\
\hline Como nós nos surpreendemos! & Как удивлялись мы! \\
\hline Tchátski & Чацкий \\
\hline Que tipo de surpresa há aqui? & Какое ж диво тут? \\
\hline
\end{tabular}




\section{Moltchálin}

Nós lastimamos por você.

\section{Tchátski}

Trabalho perdido.

\section{Moltchálin}

Tatiána Iuriévna nos contou uma história, Quando retornou de São Petersburgo, Sobre sua relação com um ministro, Depois o rompimento...

\section{Tchátski}

E era da conta dela?

\section{Moltchálin}

De Tatiána Iuriévna.

\section{Tchátski}

Eu não a conheço.

\section{Moltchálin}

Não conhece Tatiána Iuriévna??

\section{Tchátski}

Nós não nos conhecemos nesta vida;

Ouvi dizer que ela é desarrazoada.

\section{Moltchálin}

Será que o senhor está completamente certo disso?

Tatiana Iurievna!!!

\section{Молчалин}

Жалели вас.

\section{Чацкий}

Напрасный труд.

\section{Молчалин}

Татьяна Юрьевна рассказывала что-то,

Из Петербурга воротясь,

С министрами про вашу связь,

Потом разрыв...

\section{Чацкий}

Ей почему забота?

Молчалин

Татьяне Юрьевне!

\section{Чацкий}

Я с нею не знаком.

\section{Молчалин}

С Татьяной Юрьевной!!

\section{Чацкий}

С ней век мы не встречались;

Слыхал, что вздорная.

\section{Молчалин}

Да это, полно, та ли-с?

Татьяна Юрьевна!!! 


\begin{tabular}{|c|c|}
\hline Famosa e, além disso, & Известная, - притом \\
\hline de classe e posição. & Чиновные и должностные - \\
\hline Todos são amigos e parentes dela; & Все ей друзья и все родные; \\
\hline $\begin{array}{l}\text { Irá ter com Tatiána Iuriévna ainda que uma } \\
\text { vez. }\end{array}$ & К Татьяне Юрьевне хоть раз бы съездить вам. \\
\hline Tchátski & Чацкий \\
\hline E para quê? & На что же? \\
\hline Moltchálin & Молчалин \\
\hline Assim: frequentemente & Так: частенько там \\
\hline $\begin{array}{l}\text { Nós encontramos lá proteção, onde não } \\
\text { pretendíamos. }\end{array}$ & Мы покровительство находим, где не метим. \\
\hline Tchátski & Чацкий \\
\hline $\begin{array}{l}\text { Mulheres! Em suas casas, eu as visito, mas } \\
\text { não para isso. }\end{array}$ & Я езжу к женщинам, да только не за этим. \\
\hline Moltchálin & Молчалин \\
\hline Como ela é gentil! Boa! Terna! Simples! & Как обходительна! добра! мила! проста! \\
\hline $\begin{array}{l}\text { Impossível haver bailes mais ricos que os } \\
\text { dela, }\end{array}$ & Балы дает нельзя богаче. \\
\hline Do Natal à quaresma ${ }^{\mathrm{nnn}}$ & От Рождества и до поста, \\
\hline E nas férias de verão na dátcha. & И летом праздники на даче. \\
\hline $\begin{array}{l}\text { Sim, é claro, por que não vem servir conosco } \\
\text { aqui em Moscou? }\end{array}$ & $\begin{array}{l}\text { Ну, право, что бы вам в Москве у нас } \\
\text { тужить? }\end{array}$ \\
\hline $\begin{array}{l}\text { Obteria condecorações e gozaria alegremente } \\
\text { a vida. }\end{array}$ & И награжденья брать и весело пожить? \\
\hline Tchátski & Чацкий \\
\hline $\begin{array}{l}\text { Eu me escondo da alegria quando estou a } \\
\text { negócios }\end{array}$ & $\begin{array}{l}\text { Когда в делах - я от веселий прячусь, } \\
\text { Когда дурачиться - дурачусь, }\end{array}$ \\
\hline Mas ao vadiar, que folia! & А смешивать два эти ремесла \\
\hline
\end{tabular}




\begin{tabular}{|c|c|}
\hline $\begin{array}{l}\text { Misturar trabalho e prazer é tarefa para } \\
\text { milhares de especialistas, não minha. }\end{array}$ & Есть тьма искусников, я не из их числа. \\
\hline Moltchálin & Молчалин \\
\hline $\begin{array}{l}\text { Queira me desculpar, pois aqui não vejo } \\
\text { nenhum crime; }\end{array}$ & Простите, впрочем тут не вижу преступленья; \\
\hline $\begin{array}{l}\text { Veja o próprio Foma Fómitch, você o } \\
\text { conhece? }\end{array}$ & Вот сам Фома Фомич, знаком он вам? \\
\hline Tchátski & Чацкий \\
\hline E que isso tem a ver? & Ну что ж? \\
\hline Moltchálin & Молчалин \\
\hline $\begin{array}{l}\text { Passados três ministros, ele continuava o } \\
\text { chefe da seção. }\end{array}$ & $\begin{array}{l}\text { При трех министрах был начальник } \\
\text { тделенья. }\end{array}$ \\
\hline Ele foi transferido para cá... & Переведен сюда... \\
\hline Tchátski & Чацкий \\
\hline Que maravilha! & Хорош! \\
\hline Um homem vazio, dos mais estúpidos. & Пустейший человек, из самых бестолковых. \\
\hline Moltchálin & Молчалин \\
\hline $\begin{array}{l}\text { Como é possível?! O seu estilo é posto aqui } \\
\text { como modelo! }\end{array}$ & Как можно! слог его здесь ставят в образец! \\
\hline Você leu o que ele escreveu? & Читали вы? \\
\hline Tchátski & Чацкий \\
\hline Eu não sou leitor de tolices, & Я глупостей не чтец, \\
\hline Ainda mais das exemplares. & А пуще образцовых. \\
\hline Moltchálin & Молчалин \\
\hline $\begin{array}{l}\text { Não, eu tive a oportunidade de lê-lo com } \\
\text { prazer, }\end{array}$ & $\begin{array}{l}\text { Нет, мне так довелось с приятностью } \\
\text { рочесть, }\end{array}$ \\
\hline
\end{tabular}




\begin{tabular}{|c|c|}
\hline Eu não sou escritor... & Не сочинитель я... \\
\hline Tchátski & Чацкий \\
\hline E isso é visível a todos. & И по всему заметно. \\
\hline Moltchálin & Молчалин \\
\hline Não ouso proferir uma opinião minha. & Не смею моего сужденья произнесть. \\
\hline Tchátski & Чацкий \\
\hline E para quem isso é segredo? & Зачем же так секретно? \\
\hline Moltchálin & Молчалин \\
\hline Na minha idade não ouso & В мои лета не должно сметь \\
\hline Ter minhas próprias opiniões. & Свое суждение иметь. \\
\hline Tchátski & Чацкий \\
\hline Ora, nós não somos crianças. & Помилуйте, мы с вами не ребяты, \\
\hline $\begin{array}{l}\text { Por que então somente as opiniões alheias são } \\
\text { sagradas? }\end{array}$ & Зачем же мнения чужие только святы? \\
\hline Moltchálin & Молчалин \\
\hline Pois é necessário então depender dos outros. & Ведь надобно ж зависеть от других. \\
\hline Tchátski & Чацкий \\
\hline Por que é necessário? & Зачем же надобно? \\
\hline Moltchálin & Молчалин \\
\hline Nós não ocupamos altos graus. & В чинах мы небольших. \\
\hline Tchátski (quase alto) & Чацкий (почти громко) \\
\hline Com tais pensamentos e com tal alma & С такими чувствами, с такой душою \\
\hline $\begin{array}{l}\text { É ele o escolhido! Ela só pode estar me } \\
\text { enganando, caçoando de mim! }\end{array}$ & Любим!.. Обманщица смеялась надо мною! \\
\hline
\end{tabular}




\section{Cena 4}

Noite. Todas as portas estão escancaradas, exceto a que leva ao aposento de Sófia. $\mathrm{Na}$ perspectiva, abre-se um lado iluminado do quarto. Os criados agitam-se; um deles, mais importante, diz:

Ei! Fílka, Fómka, vamos, bem feito!

As mesas de jogos, o giz, as escovas e as velas!

(bate à porta de Sófia)

Diga à senhorinha o quanto antes, Lizavieta: Natália Dmítrievna e o marido já estão no terraço de entrada.

Já chegou mais uma carruagem.

Afastam-se. Tchátski permanece só.

\section{Cena 5}

Tchátski, Natália Dmítrievna - uma jovem dama.

\section{Natália Dmítrievna}

Será que não me engano? É exatamente o mesmo rosto!

Ah! Aleksandr Andréietch, é o senhor mesmo?

\section{Tchátski}

\section{Явление 4}

Вечер. Все двери настежь, кроме в спальню к офии. В перспективе раскрывается ряд свещенных комнат. Слуги суетятся; один из их, главный, говорит:

Эй! Филька, Фомка, ну, ловчей!

Столы для карт, мел, щеток и свечей!

(Стучится к Софии в дверь.)

Скажите барышне скорее, Лизавета:

Наталья Дмитревна, и с мужем, и к крыльцу

Еще подъехала карета.

(Расходятся, остается один Чаџкий.)

Явление 5

Чацкий, Наталья Дмитриевна, молодая ама.

\section{Наталья Дмитриевна}

Не ошибаюсь ли!.. он точно, по лицу...

Ах! Александр Андреич, вы ли?

\section{Чацкий}




\begin{tabular}{|c|c|}
\hline $\begin{array}{l}\text { Olha da cabeça aos pés com dúvida. } \\
\text { Será que três anos me transformaram tanto? }\end{array}$ & $\begin{array}{l}\text { С сомненьем смотрите от ног до головы, } \\
\text { Неужли так меня три года изменили? }\end{array}$ \\
\hline Natália Dmítrievna & Наталья Дмитриевна \\
\hline Eu pensei que estivesse longe de Moscou. & Я полагала вас далеко от Москвы. \\
\hline Chegou quando? & Давно ли? \\
\hline Tchátski & Чацкий \\
\hline Hoje mesmo. & Нынче лишь... \\
\hline Natália Dmítrievna & Наталья Дмитриевна \\
\hline Para ficar? & Надолго? \\
\hline Tchátski & Чацкий \\
\hline Se tudo der certo. & Как случится. \\
\hline Vejam só, quem, ao vê-la, não se admira? & Однако, кто, смотря на вас, не подивится? \\
\hline Mais rechonchuda que antes, ficou & Полнее прежнего, похорошели страх; \\
\hline $\begin{array}{l}\text { infinitamente mais bela, mais jovem e mais } \\
\text { fresca. }\end{array}$ & Моложе вы, свежее стали; \\
\hline $\begin{array}{l}\text { O fogo, a cor e o riso brincam em todos os } \\
\text { traços. }\end{array}$ & Огонь, румянец, смех, игра во всех чертах. \\
\hline Natália Dmítrievna & Наталья Дмитриевна \\
\hline Eu me casei. & Я замужем. \\
\hline Tchátski & Чацкий \\
\hline Por que não disse antes? & Давно бы вы сказали! \\
\hline Natália Dmítrievna & Наталья Дмитриевна \\
\hline $\begin{array}{l}\text { Meu marido é um marido magnífico, aí vem } \\
\text { ele. }\end{array}$ & $\begin{array}{l}\text { Мой муж - прелестный муж, вот он сейчас } \\
\text { ойдет, }\end{array}$ \\
\hline Quer que eu o apresente? & Я познакомлю вас, хотите? \\
\hline
\end{tabular}




\section{Tchátski}

Faça o favor.

\section{Natália Dmítrievna}

E eu já sei de antemão,

Que o senhor vai gostar dele. Veja com os seus próprios olhos!

\section{Tchátski}

Eu acredito, pois é seu marido.

\section{Natália Dmítrievna}

Oh, não, senhor, não por isso.

Por ele mesmo, por caráter, por espírito.

Platón Mikháilitch, meu único, inestimável.

Agora está afastado, era militar.

E afirmam todos os que o conheciam antes

Que com sua coragem, com seu talento,

Se continuasse a servir,

Certamente, em Moscou, se tornaria um comandante ${ }^{\mathrm{ooo}}$.

\section{Cena 6}

Tchátski, Natália Dmítrievna, Platón

Mikháilovitch.

\section{Natália Dmítrievna}

Aí vem o meu Platón Mikhailitch.

\section{Tchátski}

Vejam só!

\section{Чацкий}

Прошу.

\section{Наталья Дмитриевна}

И знаю наперед,

Что вам понравится. Взгляните и судите!

\section{Чацкий}

Я верю, он вам муж.

\section{Наталья Дмитриевна}

О нет-с, не потому;

Сам по себе, по нраву, по уму.

Платон Михайлыч мой единственный, есценный!

Теперь в отставке, был военный;

И утверждают все, кто только прежде знал, Что с храбростью его, с талантом, Когда бы службу продолжал, Конечно, был бы он московским омендантом.

\section{Явление 6}

Чацкий, Наталья Дмитриевна, Платон Іихайлович

\section{Наталья Дмитриевна}

Вот мой Платон Михайлыч.

\section{Чацкий}

Ба! 


\begin{tabular}{|c|c|}
\hline $\begin{array}{l}\text { Velho amigo, nós nos conhecemos há muito, } \\
\text { eis o destino! }\end{array}$ & Друг старый, мы давно знакомы, вот судьба! \\
\hline Platón Mikháilovitch & Платон Михайлович \\
\hline Salve, Tchátski, irmão! & Здорово, Чацкий, брат! \\
\hline Tchátski & Чацкий \\
\hline Caro Platón, que agradável, & Платон любезный, славно, \\
\hline $\begin{array}{l}\text { Ao olhar para o seu rosto louvável, } \\
\text { Vê-se que está muito bem. }\end{array}$ & Похвальный лист тебе: ведешь себя исправно. \\
\hline Platón Mikháilovitch & Платон Михайлович \\
\hline Como vê, irmão: & Как видишь, брат: \\
\hline Sou um habitante de Moscou e estou casado. & Московский житель и женат. \\
\hline Tchátski & Чацкий \\
\hline $\begin{array}{l}\text { Esqueceu-se do barulho do acampamento, os } \\
\text { companheiros e irmãos? }\end{array}$ & Забыт шум лагерный, товарищи и братья? \\
\hline Está tranquilo e ocioso? & Спокоен и ленив? \\
\hline Platón Mikháilovitch & Платон Михаилович \\
\hline Não, há certas ocupações: & Нет, есть таки занятья: \\
\hline Na flauta, ando praticando um dueto & На флейте я твержу дуэт \\
\hline Em Lá menor... & А-мольный... \\
\hline Tchátski & Чацкий \\
\hline O mesmo que praticava há cinco anos? & Что твердил назад тому пять лет? \\
\hline $\begin{array}{l}\text { Que gosto imutável! De todos os maridos, o } \\
\text { preferido! }\end{array}$ & $\begin{array}{l}\text { Ну, постоянный вкус! в мужьях всего } \\
\text { ороже! }\end{array}$ \\
\hline Platón Mikháilovitch & Платон Михаилович \\
\hline $\begin{array}{l}\text { Irmão, quando casar, de mim, então, há de se } \\
\text { lembrar! }\end{array}$ & Брат, женишься, тогда меня вспомянь! \\
\hline
\end{tabular}




\begin{tabular}{|c|c|}
\hline $\begin{array}{l}\text { De tédio você também haverá de bater na } \\
\text { mesma tecla. }\end{array}$ & От скуки будешь ты свистеть одно и тоже. \\
\hline Tchátski & Чацкий \\
\hline De tédio! Como? Já paga a ele um tributo? & От скуки! как? уж ты ей платишь дань? \\
\hline Natália Dmítrievna & Наталья Дмитриевна \\
\hline $\begin{array}{l}\text { Meu Platón Mikháilitch é inclinado às } \\
\text { diversas ocupações }\end{array}$ & $\begin{array}{l}\text { Платон Михайлыч мой к занятьям склонен } \\
\text { азным, }\end{array}$ \\
\hline $\begin{array}{l}\text { Que não faz mais: os estudos, as revistas de } \\
\text { tropas, }\end{array}$ & Которых нет теперь, - к ученьям и смотрам, \\
\hline $\begin{array}{l}\text { As pistas... Às vezes ele se aborrece pela } \\
\text { manhã. }\end{array}$ & К манежу... иногда скучает по утрам. \\
\hline Tchátski & Чацкий \\
\hline $\begin{array}{l}\text { Mas, caro amigo, quem lhe permite ser } \\
\text { ocioso? }\end{array}$ & $\begin{array}{l}\text { А кто, любезный друг, велит тебе быть } \\
\text { раздным? }\end{array}$ \\
\hline $\begin{array}{l}\text { Eles lhe dariam um esquadrão no regimento. } \\
\text { É oficial subalterno ou superior? }\end{array}$ & В полк, эскадрон дадут. Ты обер или штаб? * \\
\hline Natália Dmítrievna & Наталья Дмитриевна \\
\hline $\begin{array}{l}\text { A saúde de meu Platón Mikhailitch é muito } \\
\text { fraca. }\end{array}$ & Платон Михайлыч мой здоровьем очень слаб. \\
\hline Tchátski & Чацкий \\
\hline Saúde fraca? Há muito tempo? & Здоровьем слаб! Давно ли? \\
\hline Natália Dmítrievna & Наталья Дмитриевна \\
\hline Sempre com dores de cabeça e reumatismo. & Все рюматизм и головные боли. \\
\hline Tchátski & Чацкий \\
\hline $\begin{array}{l}\text { Precisa de mais movimento. Vá para o campo, } \\
\text { a um lugar quente. }\end{array}$ & Движенья более. В деревню, в теплый край. \\
\hline
\end{tabular}




\begin{tabular}{|c|c|}
\hline $\begin{array}{l}\text { Vá montar com mais frequência. No campo é } \\
\text { verão, um paraíso. }\end{array}$ & Будь чаще на коне. Деревня летом - рай. \\
\hline Natalia Dmítrievna & Наталья Дмитриевна \\
\hline Platón Mikhailitch ama a cidade, ama & Платон Михайлыч город любит, \\
\hline $\begin{array}{l}\text { Moscou; para que arruinar seus dias no fim do } \\
\text { mundo!? }\end{array}$ & Москву; за что в глуши он дни свои погубит! \\
\hline Tchátski & Чацкий \\
\hline Na cidade, em Moscou... Que excêntrico! & Москву и город ... Ты чудак! \\
\hline E você se lembra do passado? & А помнишь прежнее? \\
\hline Platón Mikháilovitch & Платон Михаилович \\
\hline Sim, irmão, mas agora não é assim... & Да, брат, теперь не так... \\
\hline Natalia Dmítrievna & Наталья Дмитриевна \\
\hline Ah, meu querido! & Ax, мой дружочек! \\
\hline Aqui está tão fresco que eu não aguento mais, & Здесь так свежо, что мочи нет, \\
\hline Você abriu tudo e desabotoou o colete. & Ты распахнулся весь и расстегнул жилет. \\
\hline Platón Mikháilovitch & Платон Михаилович \\
\hline Agora, irmão, eu não sou mais aquele... & Теперь, брат, я не тот... \\
\hline Natalia Dmítrievna & Наталья Дмитриевна \\
\hline Ouça-me mais um pouquinho, & Послушайся разочек, \\
\hline Meu querido, abotoe o mais rápido possível. & Мой милый, застегнись скорей. \\
\hline Platón Mikháilovitch (à sangue-frio) & Платон Михайлович (хладнокровно) \\
\hline Agora. & Сейчас. \\
\hline Natalia Dmítrievna & Наталья Дмитриевна \\
\hline Vamos, afaste-se um pouco mais das portas, & Да отойди подальше от дверей, \\
\hline A corrente de ar aí atrás é duas vezes maior! & Сквозной там ветер дует сзади! \\
\hline
\end{tabular}




\section{Platón Mikháilovitch}

Agora, irmão, não sou mais aquele...

\section{Natalia Dmítrievna}

Meu anjo, pelo amor de Deus,

Afaste-se um pouco mais da porta.

Platón Mikháilovitch (olhos ao céu)

Ah! Minha Nossa Senhora!

\section{Tchátski}

Vamos, Deus é testemunha.

Realmente, você mudou muito em tão pouco tempo!

Pois não foi no ano passado, no final,

Que eu o vi no regimento? Mal rompia o dia:

Pé no estribo

e você galopava em um corcel;

Corria no vento outonal, tanto na frente

quanto na retaguarda.

Platón Mikháilovitch (com um suspiro)

$\mathrm{Oh}$ ! Meu caro! Como era gloriosa aquela vida de então.

\section{Cena 7}

Os mesmos, Príncipe Tugoúkhovski e

Princesa, com seis filhas.

Natália Dmítrievna (com a voz delicada)

Príncipe Piotr Ilítch, princesa! Meu Deus!

Princesa Zizi! Mimi!

\section{Платон Михаилович}

Теперь, брат, я не тот...

\section{Наталья Дмитриевна}

Мой ангел, Бога ради

От двери дальше отойди.

Платон Михайлович (глаза к небу)

Ax! матушка!

\section{Чацкий}

Ну, Бог тебя суди;

Уж точно, стал не тот в короткое ты время;

Не в прошлом ли году, в конце,

В полку тебя я знал? лишь утро: ногу в гремя

И носишься на борзом жеребце;

Осенний ветер дуй, хоть спереди, хоть с тыла.

Платон Михайлович (со вздохом)

Эх! братец! славное тогда житье-то было.

\section{Явление 7}

Те же, Князь Тугоуховский и Княгиня с гестью дочерьми.

Наталья Дмитриевна (тоненьким голоском) Князь Петр Ильич, княгиня! Боже мой! Княжна Зизи! Мими! 
(Beijos ruidosos, depois se sentame examinam uma a outra, dos pés à cabeça)

\section{Primeira Princesa}

Que talhe magnífico!

\section{Segunda Princesa}

Que compleição!

\section{Primeira Princesa}

Coberto com franjas.

\section{Natália Dmítrievna}

Não, se vissem meu turlurette de cetim!

\section{Terceira Princesa}

Que echarpe le cousin me presenteou!

\section{Quarta Princesa}

Ah! Sim, um barège!

\section{Quinta Princesa}

Ah! Um encanto!

\section{Sexta Princesa}

Ah! Como é amável!

\section{Princesa}

Silêncio! Quem é este no canto que fez reverência ao entrarmos?

\section{Natália Dmítrievna}

(Громкие лобызания, потом усаживаются $и$ сматривают одна другую с головы до ног.)

\section{1-я княжна}

Какой фасон прекрасный!

\section{2-я княжна}

Какие складочки!

\section{1-я княжна}

Обшито бахромой.

\section{Наталья Дмитриевна}

Нет, если б видели мой тюрлюрлю тласный!

\section{3-я княжна}

Какой эшарп cousin мне подарил!

\section{4-я княжна}

Ах! да, барежевый!

5-я княжна

Ах! прелесть!

6-я княжна

Ах! как мил!

\section{Княгиня}

Сс! - Кто это в углу, взошли мы, поклонился?

\section{Наталья Дмитриевна}




\begin{tabular}{|c|c|}
\hline O recém-chegado, Tchátski. & Приезжий, Чацкий. \\
\hline Princesa & Княгиня \\
\hline Re-for-ma-do? & От-став-ной? \\
\hline Natália Dmítrievna & Наталья Дмитриевна \\
\hline Sim, viajou, há pouco retornou. & Да, путешествовал, недавно воротился. \\
\hline Princesa & Княгиня \\
\hline E sol-tei-ro? & И хо-ло-стой? \\
\hline Natália Dmítrievna & Наталья Дмитриевна \\
\hline Sim, não é casado. & Да, не женат. \\
\hline Princesa & Княгиня \\
\hline Príncipe, príncipe, vem aqui. Mais rápido! & Князь, князь, сюда. - Живее. \\
\hline $\begin{array}{l}\text { Príncipe (aproxima-se a ela, virando o } \\
\text { ouvido ao auscultador) }\end{array}$ & Князь (к ней оборачивает слуховую трубку) \\
\hline Oi? & O-хм! \\
\hline Princesa & Княгиня \\
\hline Convide o quanto antes o conhecido de & К нам на вечер, в четверг, проси скорее \\
\hline $\begin{array}{l}\text { Natália Dmítrievna para ir a nossa casa, à } \\
\text { noite, na quinta-feira: aí está ele! }\end{array}$ & Натальи Дмитревны знакомого: вон он! \\
\hline Príncipe & Князь \\
\hline Haham! & И-хм! \\
\hline (Dirige-se a Tchátski, anda próximo a ele e & (Отправляется, вьется около Чацкого и \\
\hline tosse de leve.) & окашливает.) \\
\hline Princesa & Княгиня \\
\hline Com as filhas é assim: & Вот то-то детки: \\
\hline Vão a bailes e o paizinho os frequenta ${ }^{q q q}$ & Им бал, а батюшка таскайся на поклон; \\
\hline
\end{tabular}




\begin{tabular}{|c|c|}
\hline Para que o futuro delas não se perca; & \\
\hline $\begin{array}{l}\text { Tornaram-se terrivelmente raros os } \\
\text { cavalheiros!... }\end{array}$ & Танцовщики ужасно стали редки!.. \\
\hline Ele é kamer-iunker? ${ }^{\mathrm{rrr}}$ & Он камер-юнкер? * \\
\hline Natália Dmítrievna & Наталья Дмитриевна \\
\hline Não. & Нет. \\
\hline Princesa & Княгиня \\
\hline Ri-co? & Бо-гат? \\
\hline Natália Dmítrievna & Наталья Дмитриевна \\
\hline Oh, não! & O, нет! \\
\hline Princesa (alto, com todas as forças) & Княгиня (громко, что есть мочи) \\
\hline Príncipe, Príncipe! Volte para cá! & Князь, князь! Назад! \\
\hline Cena 8 & Явление 8 \\
\hline $\begin{array}{l}\text { Os mesmos e as Condessas Khriúmina: avó } \\
\text { e neta. }\end{array}$ & $\begin{array}{l}\text { Те же и Графини Хрюмины: бабушка и } \\
\text { нучка. }\end{array}$ \\
\hline Condessa-neta & Графиня внучка \\
\hline $\begin{array}{l}\text { Ah! Grand maman! Pois quem chega tão } \\
\text { cedo? }\end{array}$ & $\begin{array}{l}\text { Ax! Grand' maman! * Нy, кто так рано } \\
\text { риезжает? }\end{array}$ \\
\hline Nós somos as primeiras! & Мы первые! \\
\hline (desaparecem para o quarto ao lado.) & (Пропадает в боковую комнату.) \\
\hline Princesa & Княгиня \\
\hline Veja como nos insulta! & Вот нас честит! \\
\hline Diz que é a primeira e nos despreza! & Вот первая, и нас за никого считает! \\
\hline Ela é má, nunca se casou, e Deus já a perdoa. & Зла, в девках целый век, уж Бог ее простит. \\
\hline
\end{tabular}


Condessa-neta (que, ao retornar, dirige-se a Tchátski com um duplo lorgnette)

Messieur Tchátski! E em Moscou! Como está? Não mudou nada?

\section{Tchátski}

Para que eu mudaria?

\section{Condessa-neta}

Voltou solteiro?

\section{Tchátski}

Com quem iria me casar?

\section{Condessa-neta}

Longe do lar, com quem?

Oh! Nossa gente lá se casa, sem se importar com a estirpe,

$\mathrm{E}$ assim estabelecemos parentesco

Com quem se porta como uma modista.

\section{Tchátski}

Que miseráveis! Será que é preciso aguentar recriminações

De quem as imitam?

Por ousarem preferir

As originais ao invés das cópias?

\section{Cena 9}

Os mesmos e uma multidão de outros convidados. Entre os restantes, Zagoriétski.
Графиня внучка (вернувшись, направляет

а Чаиякого двойной лорнет)

Мсье Чацкий! вы в Москве! как были, все акие?

\section{Чацкий}

На что меняться мне?

\section{Графиня внучка}

Вернулись холостые?

\section{Чацкий}

На ком жениться мне?

\section{Графиня внучка}

В чужих краях на ком?

O! наших тьма, без дальних справок,

Там женятся и нас дарят родством

С искусницами модных лавок.

\section{Чацкий}

Несчастные! должны ль упреки несть

От подражательниц модисткам?

За то, что смели предпочесть

Оригиналы спискам? *

\section{Явление 9}

Те же и множество других гостей. Между рочими Загорецкий. Мужчины 


\begin{tabular}{|c|c|}
\hline $\begin{array}{l}\text { Homens surgem, reverenciam uns aos outros, } \\
\text { afastam-se para um lado, vagueiam de } \\
\text { aposento a aposento, e vice-versa. }\end{array}$ & $\begin{array}{l}\text { являются, шаркают, отходят в сторону, } \\
\text { очуют из комнаты в комнату и проч. }\end{array}$ \\
\hline $\begin{array}{l}\text { Sófia sai de seu aposento; todos vão ao seu } \\
\text { encontro. }\end{array}$ & София от себя выходит; все к ней навстречу. \\
\hline $\begin{array}{l}\text { Condessa-neta } \\
\text { Eh! Bon soir! Vous voila! Jamais trop } \\
\text { diligente, } \\
\text { Vous nous donnez toujours le plaisir de } \\
\text { l'attente. }\end{array}$ & $\begin{array}{l}\text { Графиня внучка } \\
\text { Eh! bon soir! vous voila! Jamais trop diligente, } \\
\text { Vous nous donnez toujours le plaisir de l'attente }\end{array}$ \\
\hline Zagoriétski (a Sófia) & Загорецкий (Софье) \\
\hline $\begin{array}{l}\text { A senhorita tem o bilhete para o espetáculo de } \\
\text { amanhã? }\end{array}$ & На завтрашний спектакль имеете билет? \\
\hline Sófia & София \\
\hline Não. & Нет. \\
\hline Zagoriétski & Загорецкий \\
\hline $\begin{array}{l}\text { Permita-me entregar, inútil seria escolher } \\
\text { outro }\end{array}$ & $\begin{array}{l}\text { Позвольте вам вручить, напрасно бы кто } \\
\text { зялся }\end{array}$ \\
\hline Que não eu para lhe prestar um serviço, & Другой вам услужить, зато \\
\hline Mas, em compensação, o que eu não faria?! & Куда я ни кидался! \\
\hline No escritório - tudo está esgotado, & В контору - все взято, \\
\hline Fui ao diretor, que é meu amigo, & К директору, - он мне приятель, - \\
\hline De manhãzinha, às seis horas, e a propósito! & С зарей в шестом часу, и кстати ль! \\
\hline Já à noite ninguém mais pôde conseguir; & Уж с вечера никто достать не мог; \\
\hline Mas fui, às sete, implorei e consegui; & К тому, к сему, всех сбил я с ног; \\
\hline Enfim, o bilhete foi arrancado & И этот наконец похитил уже силой \\
\hline De um velho débil, & У одного, старик он хилый, \\
\hline Meu amigo, famoso sedentário; & Мне друг, известный домосед; \\
\hline Deixe que ele fique em casa e em paz. & Пусть дома просидит в покое. \\
\hline
\end{tabular}




\section{Sófia}

Eu lhe agradeço pelo bilhete,

E em dobro pelo esforço.

Surgem ainda certas pessoas, ao mesmo tempo em que Zagoriétski afasta-se em direção aos homens.

\section{Zagoriétski}

Platón Mikháilovitch...

\section{Platón Mikháilovitch}

Fora!

Aproxima-se das mulheres, mente para elas e as ludibria;

Eu lhe contarei a grande verdade,

Que é pior do que qualquer mentira. Veja aí, irmão,

\section{(Para Tchátski)}

Eu o apresentarei!

Como o chamariam os nobres mais refinados?

Mais carinhosos? - ele é um homem mundano,

Um perfeito vigarista, um velhaco:

Antón Antónitch Zagoriétski.

Por causa dele, é preciso prevenir-se: ele é capaz de espalhar tudo

E nas cartas não se deve chamá-lo: ele trapaceia.

\section{София}

Благодарю вас за билет,

А за старанье вдвое.

(Являются еще кое-какие, тем временем агоречкий отходит к мужчинам.)

\section{Загорецкий}

Платон Михайлыч...

\section{Платон Михаилович}

Прочь!

Поди ты к женщинам, лги им и их морочь;

Я правду об тебе порасскажу такую,

Что хуже всякой лжи. Вот, брат,

(Чаикому)

рекомендую!

Как эдаких людей учтивее зовут?

Нежнее? - человек он светский,

Отъявленный мошенник, плут:

Антон Антоныч Загорецкий.

При нем остерегись: переносить горазд,

И в карты не садись: продаст. 


\section{Zagoriétski}

Que original! Um resmungão, só que sem a menor maldade.

\section{Tchátski}

Seria divertido se ele lhe ofendesse;

Além da honestidade, há uma quantidade de deleites:

Praguejam aqui, mas lá agradecem.

\section{Platón Mikháilovitch}

Oh, não, meu caro! Nós praguejamos por toda parte,

Mas nós aceitamos.

(Zagoriétski mistura-se na multidão)

\section{Cena 10}

Os mesmos e Khlióstova.

\section{Khlióstova}

Será possível que aos sessenta e cinco anos

Devo me arrastar até você, sobrinha?... Que tormento!

Não tenho mais forças! Faz uma hora que saí de Pokróvka;

A noite - eis o fim do mundo!

De tédio, trouxe comigo

Uma árabe e o cachorro;

Leve-os para se alimentar, minha querida,

Dê-lhes o resto do jantar.

Princesa, salve!

\section{Загорецкий}

Оригинал! брюзглив, а без малейшей злобы.

\section{Чацкий}

И оскорбляться вам смешно бы;

Окроме честности, есть множество отрад:

Ругают здесь, а там благодарят.

\section{Платон Михаилович}

Ох, нет, братец! у нас ругают

Везде, а всюду принимают.

(Загореиякий мешается в толпу.)

\section{Явление 10}

Те же и Хлестова.

\section{Хлестова}

Легко ли в шестьдесят пять лет

Тащиться мне к тебе, племянница?.. Чученье!

Час битый ехала с Покровки, силы нет;

Ночь - светапреставленье!

От скуки я взяла с собой

Арапку-девку да собачку;

Вели их накормить ужо, дружочек мой, От ужина сошли подачку.

Княгиня, здравствуйте! 


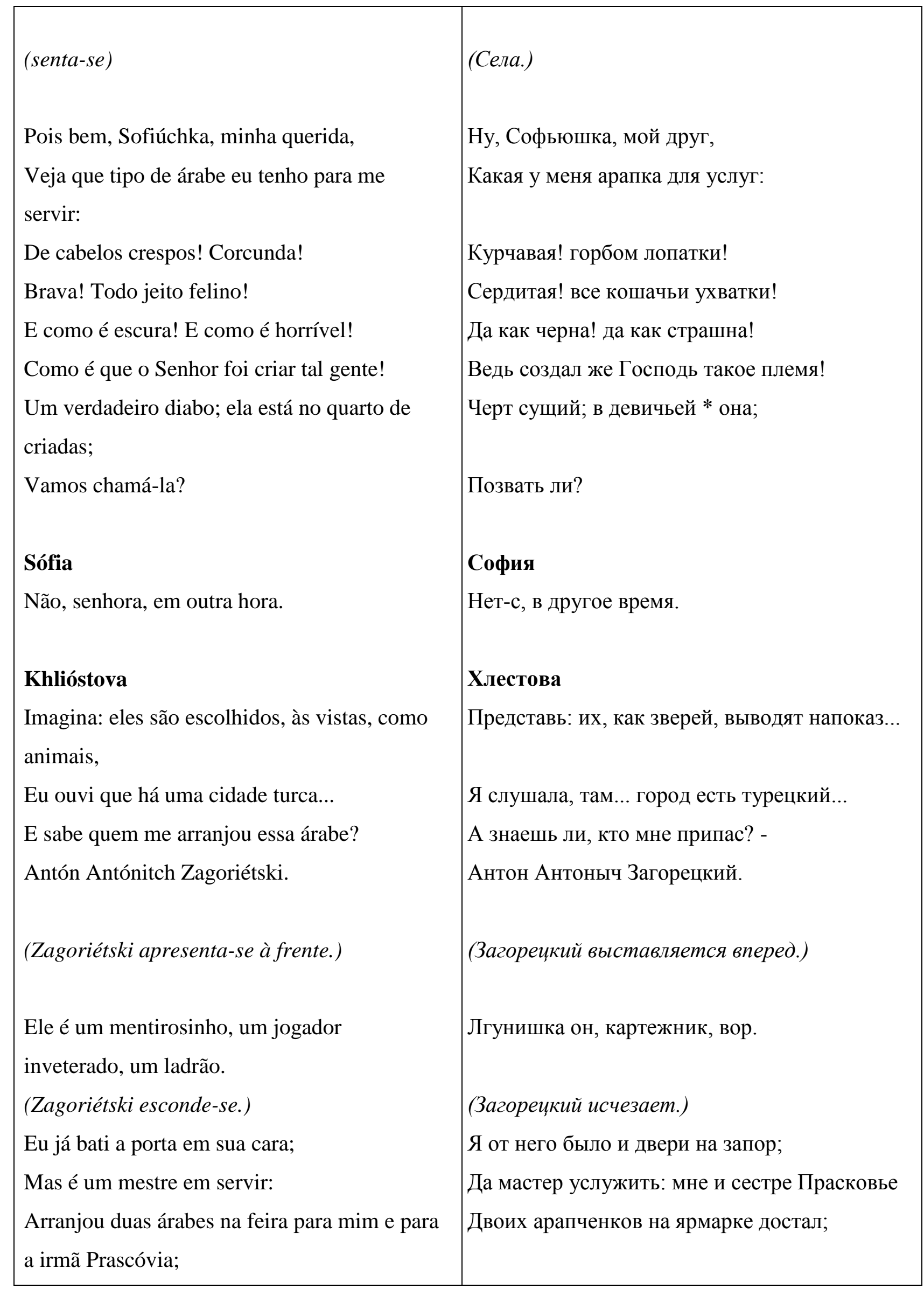




\begin{tabular}{|c|c|}
\hline $\begin{array}{l}\text { Comprou, ele disse, mas provavelmente } \\
\text { trapaceou nas cartas; }\end{array}$ & Купил, он говорит, чай в карты сплутовал; \\
\hline E me deu um presentinho, Deus lhe dê saúde! & А мне подарочек, дай Бог ему здоровье! \\
\hline $\begin{array}{l}\text { Tchátski (em uma gargalhada, a Platón } \\
\text { Mikháilovitch) }\end{array}$ & Чацкий (с хохотом Платону Михайловичу) \\
\hline $\begin{array}{l}\text { Passam-se maus bocados com os elogios dos } \\
\text { nobres, }\end{array}$ & Не поздоровится от эдаких похвал, \\
\hline E o próprio Zagoriétski não suportou, sumiu. & И Загорецкий сам не выдержал, пропал. \\
\hline Khlióstova & Хлестова \\
\hline $\begin{array}{l}\text { Quem é esse engraçadinho? De que camada } \\
\text { social? }\end{array}$ & Кто этот весельчак? Из звания какого? \\
\hline Sófia & София \\
\hline Esse aqui? É Tchátski. & Вон этот? Чацкий. \\
\hline Khlióstova & Хлестова \\
\hline É mesmo? E o que achou de engraçado? & Ну? а что нашел смешного? \\
\hline $\begin{array}{l}\text { Por que ele está contente? Que há de divertido } \\
\text { por aqui? }\end{array}$ & Чему он рад? Какой тут смех? \\
\hline É pecado divertir-se às contas da velhice. & Над старостью смеяться грех. \\
\hline $\begin{array}{l}\text { Eu me recordo, você vivia dançando com ele } \\
\text { quando eram crianças, }\end{array}$ & Я помню, ты дитей с ним часто танцевала, \\
\hline Eu já puxei suas orelhas, só que pouco. & Я за уши его дирала, только мало. \\
\hline Cena 11 & Явление 11 \\
\hline Os mesmos e Fámussov. & Те же и Фамусов. \\
\hline Fámussov (em voz alta) & Фамусов (громогласно) \\
\hline Esperamos o príncipe Piotr Ilítch, & Ждем князя Петра Ильича, \\
\hline E o príncipe já está aqui! E eu me escondi lá, & А князь уж здесь! А я забился там, в \\
\hline
\end{tabular}




\begin{tabular}{|c|c|}
\hline na sala de retratos! & ортретной! \\
\hline $\begin{array}{l}\text { Onde está Skalozúb, Serguei Sergeiitch? } \\
\text { Onde? }\end{array}$ & Где Скалозуб Сергей Сергеич? а? \\
\hline $\begin{array}{l}\text { Não, parece que não chegou. Ele é um homem } \\
\text { notável - }\end{array}$ & Нет; кажется, что нет. - Он человек заметный \\
\hline Serguei Serguéiitch Skalozúb. & Сергей Сергеич Скалозуб. \\
\hline Khlióstova & Хлестова \\
\hline $\begin{array}{l}\text { Santo Criador! O senhor buzina mais que uma } \\
\text { corneta! }\end{array}$ & Творец мой! оглушил, звончее всяких труб! \\
\hline Cena 12 & Явление 12 \\
\hline Os mesmos e Skalozúb, depois Moltchálin. & Те же и Скалозуб, потом Молчалин. \\
\hline Fámussov & Фамусов \\
\hline Serguei Serguéiitch, está atrasado; & Сергей Сергеич, запоздали; \\
\hline $\begin{array}{l}\text { Pois nós o esperávamos, esperávamos e } \\
\text { esperávamos. }\end{array}$ & А мы вас ждали, ждали, ждали. \\
\hline (conduz-se até Khlióstova.) & (Подводит к Хлестовой.) \\
\hline Minha cunhadinha, que há muito & Моя невестушка, которой уж давно \\
\hline Sobre o senhor já foi dito. & Об вас говорено. \\
\hline Khlióstova (ao sentar) & Хлестова (сидя) \\
\hline $\begin{array}{l}\text { Esteve aqui antes... No regimento... Naquele... } \\
\text { De granadeiros? }\end{array}$ & $\begin{array}{l}\text { Вы прежде были здесь... в полку... в том... в } \\
\text { ренадерском? }\end{array}$ \\
\hline Skalozúb (com voz de baixo) & Скалозуб (басом) \\
\hline A senhora se refere ao regimento & В его высочества, хотите вы сказать, \\
\hline Nova-Zemiliánski, comandado pelo príncipe & Ново-землянском мушкетерском. \\
\hline
\end{tabular}




\begin{tabular}{|c|c|}
\hline herdeiro? & \\
\hline Khlióstova & Хлестова \\
\hline Não sou mestra em distinguir regimentos. & Не мастерица я полки-та различать. \\
\hline Skalozúb & Скалозуб \\
\hline Mas nos uniformes há condecorações: & А форменные есть отлички: \\
\hline Nas tranças das fardas, dragonas, botoeiras. & В мундирах выпушки, погончики, петлички. \\
\hline Fámussov & Фамусов \\
\hline Vamos, paizinho, lá eu o farei se divertir; & Пойдемте, батюшка, там вас я насмешу; \\
\hline $\begin{array}{l}\text { Nós temos um whist curioso. Venha conosco, } \\
\text { príncipe!, eu lhe peço. }\end{array}$ & Курьезный вист у нас. За нами, князь! прошу. \\
\hline (Skalozúb e o príncipe saem com ele.) & (Его и князя уводит с собою.) \\
\hline Khlióstova (para Sófia) & Хлестова (Софии) \\
\hline $\begin{array}{l}\text { Oh! Por pouquinho e eu não me livro desse } \\
\text { castigo; }\end{array}$ & Ух ! я точнехонько избавилась от петли; \\
\hline Pois seu pai é para lá de maluco; & Ведь полоумный твой отец: \\
\hline Não sei o que ele vê nesse grandalhão. & Дался ему трех сажень удалец, - \\
\hline $\begin{array}{l}\text { Apresenta-nos as pessoas sem perguntar se } \\
\text { isso nos agrada ou não! }\end{array}$ & $\begin{array}{l}\text { Знакомит, не спросясь, приятно ли нам, нет } \\
\text { и? }\end{array}$ \\
\hline Moltchálin (oferece-lhe uma carta) & Молчалин (подает ей карту) \\
\hline Eu montei a sua partida, senhora: & Я вашу партию составил: мосье Кок, \\
\hline Messieur Kok, Foma Fómitch e eu. & Фома Фомич и я. \\
\hline Khlióstova & Хлестова \\
\hline Obrigada, meu amigo. & Спасибо, мой дружок. \\
\hline (Levanta-se.) & (Bcmaem.) \\
\hline Moltchálin & Молчалин \\
\hline Seu lulu é um magnífico lulu, menor que um & Ваш шпиц - прелестный шпиц, не более \\
\hline
\end{tabular}




\begin{tabular}{|c|c|}
\hline dedal! & аперстка! \\
\hline Eu o acariciei todo; que pêlo sedoso! & Я гладил все его; как шелковая шерстка! \\
\hline Khlióstova & Хлестова \\
\hline Obrigada, meu querido. & Спасибо, мой родной. \\
\hline (Sai, atrás dela Moltchálin e muitos outros.) & (Уходит, за нею Молчалин и многие другие.) \\
\hline Cena 13 & Явление 13 \\
\hline $\begin{array}{l}\text { Tchátski, Sófia e alguns estranhos, que se } \\
\text { dispersam em sequência. }\end{array}$ & $\begin{array}{l}\text { Чацкий, София и несколько посторонних, } \\
\text { оторые в продолжении расходятся. }\end{array}$ \\
\hline Tchátski & Чацкий \\
\hline Eia! Ele dissolveu a nuvem... & Ну! тучу разогнал... \\
\hline Sófia & София \\
\hline Será que vai continuar com isso? & Нельзя ль не продолжать? \\
\hline Tchátski & Чацкий \\
\hline Que é que eu fiz para assustá-la? & Чем вас я напугал? \\
\hline Queria eu elogiar, & За то, что он смягчил разгневанную гостью, \\
\hline Pois que ele acalmou uma convidada zangada. & Хотел я похвалить. \\
\hline Sófia & София \\
\hline Mas terminaria com fúria. & А кончили бы злостью. \\
\hline Tchátski & Чацкий \\
\hline Devo lhe dizer o que penso? Pois bem: & Сказать вам, что я думал? Вот: \\
\hline Todas as velhinhas são uma gente severa; & Старушки все - народ сердитый; \\
\hline É bom para elas que aqui esteja um servidor & Не худо, чтоб при них услужник знаменитый \\
\hline notável, como um pára-raios. & Тут был, как громовой отвод. \\
\hline $\begin{array}{l}\text { Moltchálin! - quem senão ele desembaraça } \\
\text { tudo pacificamente! }\end{array}$ & $\begin{array}{l}\text { Молчалин! - Кто другой так мирно все } \\
\text { ладит! }\end{array}$ \\
\hline
\end{tabular}




\begin{tabular}{|c|c|}
\hline Lá ele acaricia um cãozinho e oportunamente! & Там моську вовремя погладит! \\
\hline Aqui ele prepara as cartas a tempo! & Тут в пору карточку вотрет! \\
\hline Com ele, Zagoriétski não morrerá nunca! & В нем Загорецкий не умрет! \\
\hline $\begin{array}{l}\text { Há pouco a senhorita enumerou as suas } \\
\text { qualidades, }\end{array}$ & Вы давиче его мне исчисляли свойства, \\
\hline $\begin{array}{l}\text { Mas se esqueceu de muitas? - Não é mesmo? } \\
\text { (sai.) }\end{array}$ & $\begin{array}{l}\text { Но многие забыли? - да? } \\
\text { (Уходит.) }\end{array}$ \\
\hline Cena 14 & ЯВЛЕНИЕ 14 \\
\hline Sófia, depois $\mathbf{S} . \mathbf{N}^{\text {sss }}$. & София, потом Г.N. \\
\hline Sófia (para si) & София (про себя) \\
\hline Ah! Este homem é sempre para mim & Ax! этот человек всегда \\
\hline Motivo de uma desordem terrível! & Причиной мне ужасного расстройства! \\
\hline $\begin{array}{l}\text { Gosta de humilhar, alfinetar; é invejoso, } \\
\text { Orgulhoso e mal! }\end{array}$ & Унизить рад, кольнуть, завистлив, горд и зол! \\
\hline $\begin{array}{l}\text { S.N. } \\
\text { (aproxima-se) }\end{array}$ & $\begin{array}{l}\text { Г.N. } \\
\text { (nodxodum) }\end{array}$ \\
\hline No que está pensando? & Вы в размышленьи. \\
\hline Sófia & София \\
\hline Em Tchátski. & Об Чацком. \\
\hline S.N. & Г.N. \\
\hline Como ele está, após esse retorno? & Как его нашли по возвращеньи? \\
\hline Sófia & София \\
\hline Ele não está em seu juízo perfeito. & Он не в своем уме. \\
\hline $\begin{array}{l}\text { S.N. } \\
\text { Será que enlouqueceu? }\end{array}$ & $\begin{array}{l}\text { Г.N. } \\
\text { Ужли с ума сошел? }\end{array}$ \\
\hline
\end{tabular}


Sófia (tentando silenciar-se)

Não inteiramente...

\section{S.N.}

No entanto há indícios?

Sófia (olha fixamente para ele)

Ao que parece.

S.N.

Como é possível, nessa idade!

\section{Sófia}

O que se pode fazer!

(à parte)

Ele está prestes a acreditar.

Ah, Tchátski! Você ama fazer os outros de tolos,

Gostaria de provar do próprio veneno? (sai.)

\section{Cena 15}

S.N., depois S.D ${ }^{\mathrm{ttt}}$.

S.N.

Enlouqueceu! É o que lhe parece... Essa é boa!

Não sem razão? Pois então... Por que ela pensa isso?

Ouviu?

\section{София (помолчавши)}

Не то, чтобы совсем...

Г.N.

Однако есть приметы?

София (смотрит на него пристально)

Мне кажется.

Г.N.

Как можно, в эти леты!

\section{София}

Как быть!

(В сторону)

Готов он верить!

А, Чацкий! Любите вы всех в шуты рядить,

Угодно ль на себя примерить?

(Уходит.)

\section{ЯВЛЕНИЕ 15}

Г.N., потом Г.D.

Г.N.

С ума сошел!.. Ей кажется!.. вот на!

Недаром? Стало быть... с чего б взяла она?

Ты слышал? 


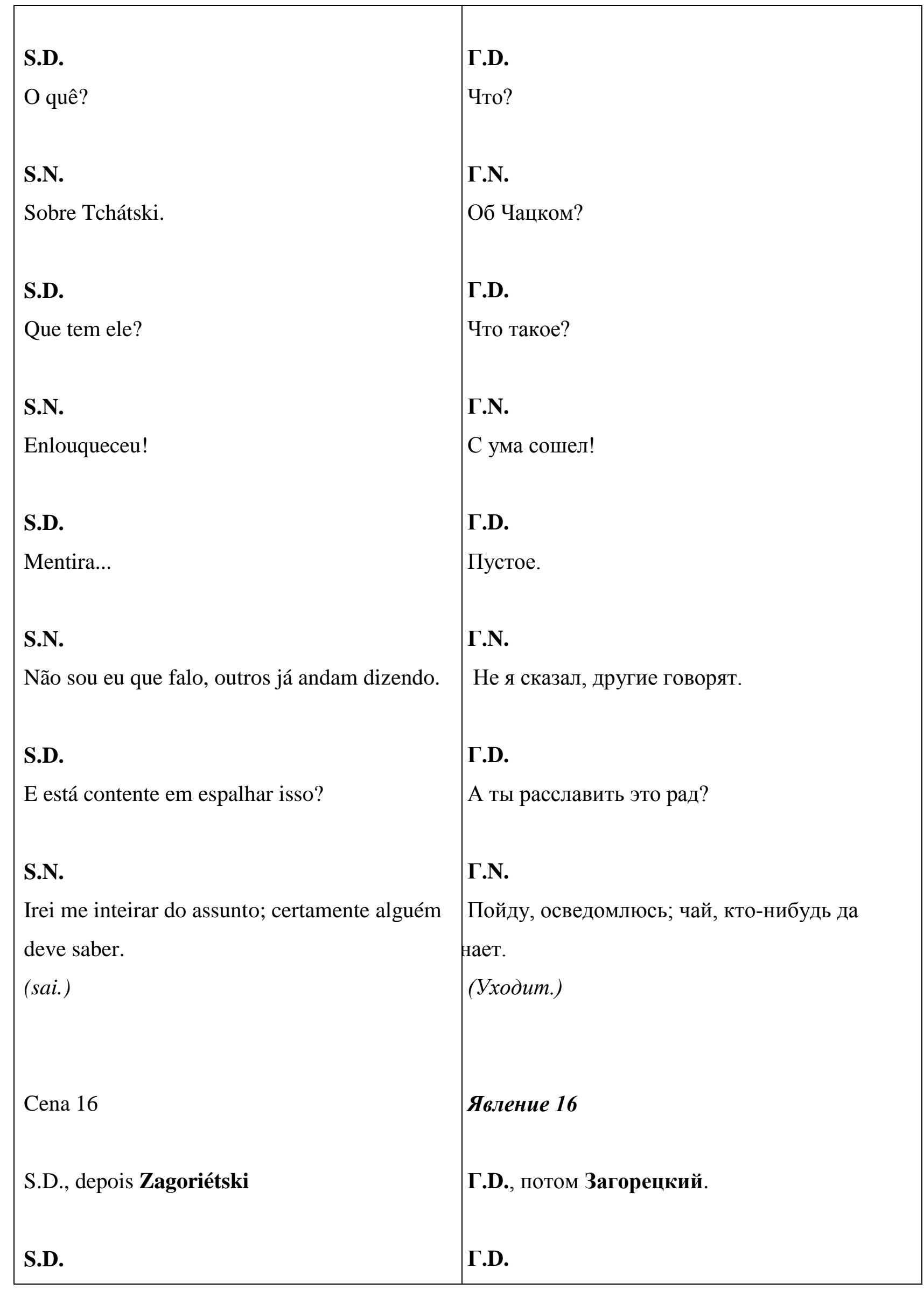




\begin{tabular}{|c|c|}
\hline Acredita nesse tagarela! & Верь болтуну! \\
\hline $\begin{array}{l}\text { Escuta um absurdo e no mesmo instante põe- } \\
\text { se a repeti-lo! }\end{array}$ & Услышит вздор, и тотчас повторяет! \\
\hline Você sabe sobre Tchátski? & Ты знаешь ли об Чацком? \\
\hline Zagoriétski & Загорецкий \\
\hline Quê? & Hy? \\
\hline S.D. & Г.D. \\
\hline Enlouqueceu! & С ума сошел! \\
\hline Zagoriétski & Загорецкий \\
\hline Ah, sei, me lembro, escutei, & А! знаю, помню, слышал. \\
\hline $\begin{array}{l}\text { Como não saberia? Aconteceu um fato } \\
\text { exemplar. }\end{array}$ & Как мне не знать? примерный случай вышел; \\
\hline Seu tio, um velhaco, escondeu-o por loucura. & Его в безумные упрятал дядя-плут... \\
\hline $\begin{array}{l}\text { Amarraram-no, no manicômio, entre } \\
\text { correntes. }\end{array}$ & Схватили, в желтый дом, и на цепь посадили. \\
\hline S.D. & Г.D. \\
\hline Ora! Ele esteve agora cá, no aposento, aqui. & Помилуй, он сейчас здесь в комнате был, тут. \\
\hline Zagoriétski & Загорецкий \\
\hline Pois então se livrou das correntes. & Так с цепи, стало быть, спустили. \\
\hline S.D. & Г.D. \\
\hline $\begin{array}{l}\text { Vamos, caro amigo, contigo não é preciso de } \\
\text { jornais. }\end{array}$ & Ну, милый друг, с тобой не надобно газет. \\
\hline $\begin{array}{l}\text { Pois eu vou é descobrir tudo e espalhar a } \\
\text { todos; Era uma vez um segredo! } \\
\text { (sai.) }\end{array}$ & $\begin{array}{l}\text { Пойду-ка я, расправлю крылья, } \\
\text { У всех повыспрошу; однако чур! секрет. } \\
\text { Уходит. }\end{array}$ \\
\hline
\end{tabular}


Cena 17

Zagoriétski, depois a condessa-neta

\section{Zagoriétski}

Qual Tchátski está aqui? - é uma família importante.

Alguma vez eu fui apresentado a um certo Tchátski.

A senhorita escutou algo sobre ele?

\section{Condessa-neta}

Sobre quem?

\section{Zagoriétski}

Sobre Tchátski; ele esteve aqui agora, no aposento.

\section{Condessa-neta}

Sei.

Eu falava com ele.

\section{Zagoriétski}

Assim eu lhe saúdo:

Ele enlouqueceu...

\section{Condessa-neta}

Como?

\section{Zagoriétski}

Sim, ele enlouqueceu.

Condessa-neta
Явление 17

Загорецкий, потом Графиня внучка.

\section{Загорецкий}

Который Чацкий тут? - Известная фамилья.

С каким-то Чацким я когда-то был знаком. -

Вы слышали об нем?

\section{Графиня внучка}

Об ком?

\section{Загорецкий}

Об Чацком, он сейчас здесь в комнате был.

\section{Графиня внучка}

Знаю.

Я говорила с ним.

\section{Загорецкий}

Так я вас поздравляю!

Он сумасшедший...

\section{Графиня внучка}

Что?

\section{Загорецкий}

Да, он сошел с ума.

Графиня внучка 


\begin{tabular}{|c|c|}
\hline Imagine, eu mesma percebi; & Представьте, я заметила сама; \\
\hline E pode apostar que pensei o mesmo que você. & $\begin{array}{l}\text { И хоть пари держать, со мной в одно вы } \\
\text { пово. }\end{array}$ \\
\hline Cena 18 & Явление 18 \\
\hline Os mesmos e a condessa-avó. & Те же и Графиня бабушка. \\
\hline Condessa-neta & Графиня внучка \\
\hline Ah! Grand'maman, é um milagre! Novidades! & Ah! grand' maman, вот чудеса! вот ново! \\
\hline A senhora não escutou as desgraças daqui? & Вы не слыхали здешних бед? \\
\hline Ouça. É fascinante! Essa é boa!... & Послушайте. Вот прелести! вот мило!.. \\
\hline Condessa-avó & Графиня бабушка \\
\hline Meu amigo, meus ouvidos estão tampados ${ }^{\text {uuu, }}$ & Мой труг, мне уши залошило; \\
\hline Fale mais alto... & Скаши покромче... \\
\hline Condessa-neta & Графиня внучка \\
\hline Não há tempo! & Время нет! \\
\hline (aponta Zagoriétski) & (Указывает на Загорецякого.) \\
\hline Il vous dirá toute l'histoire. & Il vous dira toute l'histoire... * \\
\hline Vá perguntá-lo... & Пойду, спрошу... \\
\hline (sai.) & (Уходит.) \\
\hline Cena 19 & Явление 19 \\
\hline Zagoriétski, condessa-avó & Загорецкий, Графиня бабушка. \\
\hline Condessa-avó & Графиня бабушка \\
\hline $\begin{array}{l}\text { Quê? Quê? Não há por aqui um incêndio, } \\
\text { certo? }\end{array}$ & Что? что? уж нет ли здесь пошара? \\
\hline Zagoriétski & Загорецкий \\
\hline Não, Tchátski é o responsável por toda essa & Нет, Чацкий произвел всю эту кутерьму. \\
\hline
\end{tabular}




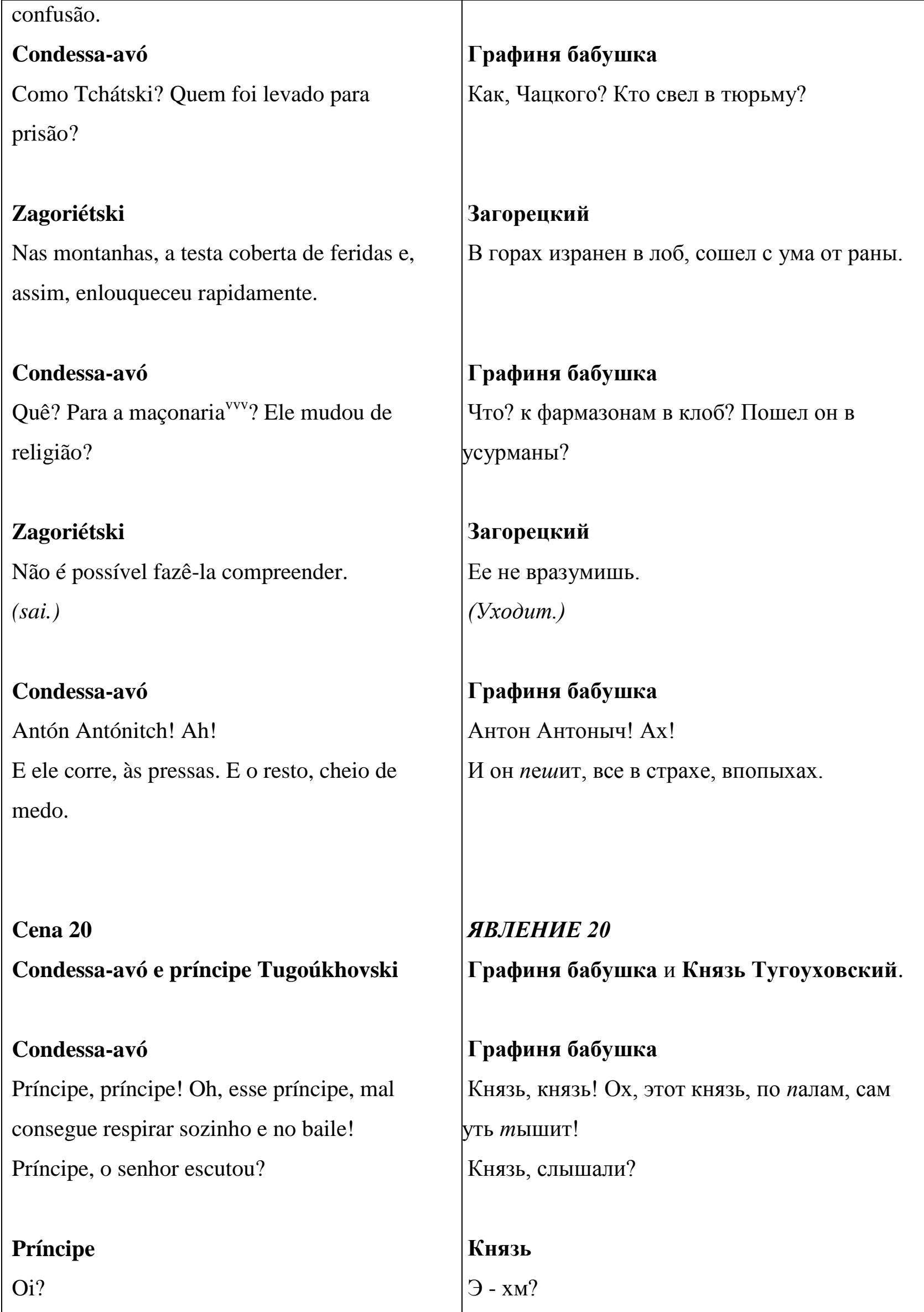




\section{Condessa-avó}

Ele não escuta nada.

Pelo menos, talvez, viu se esteve aqui o chefe de polícia?

\section{Príncipe}

$\mathrm{Ah}$ ?

\section{Condessa-avó}

Para alguma prisão, príncipe, quem apanhou Tchátski?

\section{Príncipe}

Como?

\section{Condessa-avó}

Deram-lhe uma espada e uma mochila, Para ser soldado! Não é brincadeira: ele transgrediu a lei!

\section{Príncipe}

Quê?

\section{Condessa-avó}

Sim! Ele mudou de crenças!

Ah, maldito voltairiano ${ }^{\text {www }}$ !

Quê? Ah? Está surdo, meu pai; tire esse negócio do ouvido.

Ah! A surdez é um grande defeito.

\section{Графиня бабушка}

Он ничего не слышит!

Хоть, мошет, видели, здесь полицмейстер * ыл?

\section{Князь}

Э - хм?

\section{Графиня бабушка}

В тюрьму-та, князь, кто Чацкого схватил?

\section{Князь}

И - хм?

\section{Графиня бабушка}

Тесак ему да ранец,

В солтаты! Шутка ли! переменил закон!

\section{Князь}

У-хм?

\section{Графиня бабушка}

Да!.. в пусурманах он! Ах! окаянный олтерьянец!

Что? a? глух, мой отец; достаньте свой рожок.

Ох! глухота большой порок. 


\section{Cena 21}

Os mesmos e Khlióstova, Sófia, Moltchálin, Platón Mikháilovitch, Natália Dmítrievna, Condessa-neta, princesa com as filhas, Zagoriétski, Skalozúb, depois

Fámussov e muitos outros.

\section{Khlióstova \\ Enlouqueceu! Não me diga uma coisa dessas! E por acaso! E com que velocidade! \\ Sófia, escutou essa?}

\section{Platón Mikháilovitch}

Quem espalhou isso primeiro?

\section{Natália Dmítrievna}

Oh, meu caro, todo mundo!

\section{Platón Mikháilovitch}

Ora, tudo o que se crê a contragosto

Me parece de caráter duvidoso.

\section{Fámussov (entrando)}

Sobre o quê? Sobre Tchátski, será?

Por que duvidoso? Eu fui o primeiro, eu falei primeiro!

Há muito eu me admirava como ninguém o amarrava!

Experimenta lhe falar sobre as autoridades e ele dirá algo inconcebível! A menor mesura frente a alguém
ЯВЛЕНИЕ 21

Те же и Хлестова, София, Молчалин,

Ілатон Михайлович, Наталья

Дмитриевна, Графиня внучка, Княгиня с

очерьми, Загорецкий, Скалозуб, потом

Фамусов и многие другие.

\section{Хлестова}

С ума сошел! прошу покорно!

Да невзначай! да как проворно!

Ты, Софья, слышала?

\section{Платон Михайлович}

Кто первый разгласил?

\section{Наталья Дмитриевна}

Ах, друг мой, все!

\section{Платон Михайлович}

Ну все, так верить поневоле,

А мне сомнительно.

Фамусов (вход $я)$

О чем? о Чацком, что ли?

Чего сомнительно? Я первый, я открыл!

Давно дивлюсь я, как никто его не свяжет!

Попробуй о властях - и нивесть что наскажет! Чуть низко поклонись, согнись-ка кто ольцом, 


\begin{tabular}{|c|c|}
\hline Ainda que seja a um monarca, & Хоть пред монаршиим лицом, \\
\hline Ele assim chama de patife!... & Так назовет он подлецом!.. \\
\hline Khlióstova & Хлестова \\
\hline Isso acontece com quem vive rindo. & Туда же из смешливых; \\
\hline Eu disse algo - ele começou a gargalhar. & Сказала что-то я - он начал хохотать. \\
\hline Moltchálin & Молчалин \\
\hline Ele me desaconselhou a servir nos arquivos de & Мне отсоветовал в Москве служить в \\
\hline Moscou. & рхивах. \\
\hline Condessa-neta & Графиня внучка \\
\hline Ele se dignou a me chamar de modista! & Меня модисткою изволил величать! \\
\hline Natália Dmítrievna & Наталья Дмитриевна \\
\hline $\begin{array}{l}\text { Pois ao meu marido, aconselhou que fosse } \\
\text { morar no campo. }\end{array}$ & А мужу моему совет дал жить в деревне. \\
\hline Zagoriétski & Загорецкий \\
\hline Um louco, ao que tudo indica. & Безумный по всему. \\
\hline Condessa-neta & Графиня внучка \\
\hline Eu vi com esses meus próprios olhos. & Я видела из глаз. \\
\hline Fámussov & Фамусов \\
\hline Pegou isso da mãe, de Anna Aliekseievna; & По матери пошел, по Анне Алексевне; \\
\hline A falecida enlouqueceu oito vezes. & Покойница с ума сходила восемь раз. \\
\hline Khlióstova & Хлестова \\
\hline $\begin{array}{l}\text { No mundo acontecem surpreendentes } \\
\text { incidentes! }\end{array}$ & На свете дивные бывают приключенья! \\
\hline Perdeu o senso nessa idade! & В его лета с ума спрыгнул! \\
\hline Certamente bebe mais do que devia! & Чай, пил не по летам. \\
\hline
\end{tabular}




\begin{tabular}{|c|c|}
\hline Princesa & Княгиня \\
\hline Oh! Decerto... & О! верно... \\
\hline Condessa-neta & Графиня внучка \\
\hline Sem dúvida. & Без сомненья. \\
\hline Khlióstova & Хлестова \\
\hline Bebeu copos de champagne. & Шампанское стаканами тянул. \\
\hline Natalia Dmítrievna & Наталья Дмитриевна \\
\hline Garrafas, senhora, e muito grandes. & Бутылками-с, и пребольшими \\
\hline Zagoriétski (com ardor) & Загорецкий (с жаром) \\
\hline Não, senhora, barris enormes. & Нет-с, бочками сороковыми. \\
\hline Fámussov & Фамусов \\
\hline Ora essa! Uma grande desgraça & Ну вот! великая беда, \\
\hline Que um homem beba nessa quantidade! & Что выпьет лишнее мужчина! \\
\hline $\begin{array}{l}\text { Os estudos - eis a peste. A erudição - eis o } \\
\text { motivo }\end{array}$ & Ученье - вот чума, ученость - вот причина, \\
\hline Pelo qual hoje em dia, mais do que nunca, & Что нынче пуще, чем когда, \\
\hline $\begin{array}{l}\text { As opiniões e os negócios separam as pessoas } \\
\text { dos loucos. }\end{array}$ & Безумных развелось людей, и дел, и мнений. \\
\hline Khlióstova & Хлестова \\
\hline E realmente enlouquece-se disso, & И впрямь с ума сойдешь от этих, от одних \\
\hline $\begin{array}{l}\text { Dos internatos, escolas, liceus, seja qual for o } \\
\text { nome; }\end{array}$ & От пансионов, школ, лицеев, как бишь их, \\
\hline E da educação mútua lancasteriana ${ }^{\mathrm{xxx}}$. & Да от ланкартачных взаимных обучений. * \\
\hline Princesa & Княгиня \\
\hline Não, em Petersburgo, o instituto & Нет, в Петербурге институт \\
\hline
\end{tabular}


Pe-da-gó-gico, assim, parece-me, se chama:

Lá os professores praticam as cisões e a incredulidade,

- um parente nosso estudou com eles

e se formou, ainda que agora seja aprendiz em uma farmácia!

Foge das mulheres e até de mim!

Nem quer saber de obter graus! Ele é químico, ele é botânico,

Príncipe Fiódor, meu sobrinho.

\section{Skalozúb}

Boas notícias: o rumor geral

É de que lá no projeto acerca dos liceus, das escolas, dos ginásios

Só ensinarão à nossa maneira: bem simples;

E os livros se conservam assim: para as ocasiões excepcionais $^{\mathrm{yyy}}$.

\section{Fámussov}

Serguei Sergueiitch, não! Já o caso seria evitar o mal:

Apoderar-se de todos os livros e jogá-los ao fogo.

\section{Zagoriétski}

Não, senhor, há livros e livros. E se, entre nós, eu houvesse sido designado censor,

As fábulas seriam banidas;

Oh! São as fábulas que dão cabo de nós!

Eternas troças sobre os leões! Sobre as águias!

Pois digam o que quiserem:

Ainda que animais, eles são, acima de tudo,
Пе-да-го-гический, так, кажется, зовут:

Там упражняются в расколах и в безверьи

Профессоры!! - у них учился наш родня,

И вышел! хоть сейчас в аптеку, в

одмастерьи.

От женщин бегает, и даже от меня!

Чинов не хочет знать! Он химик, он ботаник,

Князь Федор, мой племянник.

\section{Скалозуб}

Я вас обрадую: всеобщая молва,

Что есть проект насчет лицеев, школ, имназий;

Там будут лишь учить по нашему: раз, два; А книги сохранят так: для больших оказий.

\section{Фамусов}

Сергей Сергеич, нет! Уж коли зло пресечь:

Забрать все книги бы да сжечь.

\section{Загорецкий (с кротостию)}

Нет-с, книги книгам рознь. А если б, между ами,

Был ценсором назначен я,

На басни бы налег; ох! басни - смерть моя! Насмешки вечные над львами! над орлами! Кто что ни говори:

Хотя животные, а все-таки цари. 


\begin{tabular}{|c|c|}
\hline reis. & \\
\hline Khlióstova & Хлестова \\
\hline $\begin{array}{l}\text { Meus caros, para quem já tem a mente em } \\
\text { desarranjo, }\end{array}$ & Отцы мои, уж кто в уме расстроен, \\
\hline Tanto faz se é pelos livros, se é pela bebida, & Так все равно, от книг ли, от питья ль; \\
\hline Mas tenho pena de Tchátski. & А Чацкого мне жаль. \\
\hline $\begin{array}{l}\text { Para cristãos como nós, ele é digno de } \\
\text { piedade. }\end{array}$ & По-христиански так; он жалости достоин; \\
\hline Foi um homem mordaz, tinha trezentas almas. & Был острый человек, имел душ сотни три. \\
\hline Fámussov & Фамусов \\
\hline Quatrocentas. & Четыре. \\
\hline Khlióstova & Хлестова \\
\hline Trezentas, senhor. & Три, сударь. \\
\hline Fámussov & Фамусов \\
\hline Quatrocentas. & Четыреста. \\
\hline Khlióstova & Хлестова \\
\hline Não! Trezentas. & Нет! триста. \\
\hline Fámussov & Фамусов \\
\hline Em meu calendário... & В моем календаре... \\
\hline Khlióstova & Хлестова \\
\hline Tudo errado nesse calendário... & Все врут календари. \\
\hline Fámussov & Фамусов \\
\hline $\begin{array}{l}\text { Exatamente quatrocentas, oh! Aposto com a } \\
\text { voz forte e sonora! }\end{array}$ & Как раз четыреста, ох! спорить голосиста! \\
\hline Khlióstova & Хлестова \\
\hline
\end{tabular}




\begin{tabular}{|c|c|}
\hline $\begin{array}{l}\text { Não! Trezentas - como se eu já não soubesse } \\
\text { o que os outros têm... }\end{array}$ & $\begin{array}{l}\text { Нет! Триста! - уж чужих имений мне не } \\
\text { нать! }\end{array}$ \\
\hline Fámussov & Фамусов \\
\hline Quatrocentas, peço que compreenda. & Четыреста, прошу понять. \\
\hline Khlióstova & Хлестова \\
\hline Não! Trezentas, trezentas, trezentas. & Нет! триста, триста, триста. \\
\hline Cena 22 & Явление 22 \\
\hline Os mesmos e Tchátski & Те же все и Чацкий. \\
\hline Natalia Dmítrievna & Наталья Дмитриевна \\
\hline Olhem ele aí. & Вот он. \\
\hline Condessa-neta & Графиня внучка \\
\hline Shsh! & Шш! \\
\hline Todos & Bce \\
\hline Shsh! & 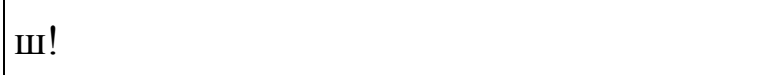 \\
\hline (recuam-se para o lado contrário ao dele.) & (Пятятся от него в противную сторону.) \\
\hline Khlióstova & Хлестова \\
\hline Será que ele vai pedir satisfação em um & Ну, как с безумных глаз \\
\hline ( & Затеет драться он, потребует к разделке! \\
\hline Fámussov & Фамусов \\
\hline $\begin{array}{l}\text { Meu Deus! Perdoe a nós, pecadores! } \\
\text { (cautelosamente) }\end{array}$ & $\begin{array}{l}\text { О Господи! помилуй грешных нас! } \\
(\text { Опасливо) }\end{array}$ \\
\hline $\begin{array}{l}\text { Caríssimo! Você não está em seu juízo! } \\
\text { É preciso de sono após a viagem. Vá medir os } \\
\text { pulsos... Você não está saudável. }\end{array}$ & $\begin{array}{l}\text { Любезнейший! Ты не в своей тарелке. } \\
\text { С дороги нужен сон. Дай пульс... Ты } \\
\text { ездоров. }\end{array}$ \\
\hline
\end{tabular}




\section{Tchátski}

Sim, não tenho forças: um milhão de

tormentos $^{\text {zzz }}$

No peito, pelos abraços apertados dos

conhecidos;

Nas pernas, por reverenciar a todo o canto;

Nos ouvidos, pelas exclamações;

Mas mais na cabeça, por causa de toda e

qualquer tolice.

(aproxima-se de Sófia)

Tenho cá na alma algum tipo de angústia comprimida,

E eu estou perdido na multidão, já não sou eu mesmo.

Não! Estou descontente com Moscou.

\section{Khlióstova}

Vejam só, Moscou é que é culpada!

\section{Fámussov}

Afaste-se dele.

(faz um sinal para Sófia)

Ei, Sófia! - Ela não vê!

Sófia (a Tchátski)

Diga, o que tanto o enfurece?

\section{Tchátski}

Houve um encontro insignificante naquele aposento.

Um francesinho de Bordeaux ${ }^{\text {aaaa }}$, reunindo em torno de si

\section{Чацкий}

Да, мочи нет: мильон терзаний

Груди от дружеских тисков,

Ногам от шарканья, ушам от восклицаний,

А пуще голове от всяких пустяков.

(Подходит к Софье.)

Душа здесь у меня каким-то горем сжата,

И в многолюдстве я потерян, сам не свой.

Нет! недоволен я Москвой.

\section{Хлестова}

Москва, вишь, виновата.

\section{Фамусов}

Подальше от него.

(Делает знаки Софии.)

Гм, Софья! - Не глядит!

София (Чаџкому)

Скажите, что вас так гневит?

\section{Чацкий}

В той комнате незначащая встреча:

Французик из Бордо, * надсаживая грудь, 
Uma espécie de assembleia, gritava com toda a força,

E contava como se preparara, com horror e lágrimas,

No caminho para a Rússia, para os bárbaros;

Chegou e descobriu que os prazeres são infinitos;

Não encontrou um vestígio russo, sequer uma face

Russa: mesmo em sociedade, com os amigos; Sua província estava lá. Vejam, à noitinha, Ele se sentia como um pequeno czar, Pois as damas tinham os mesmos modos, o mesmo jeito...

Ele parecia contente, mas nós não.

Um silêncio. E, então, de todos os lados A nostalgia, os lamentos, os ais:

“Ah! A França! Não há no mundo melhor lugar!"bbbb _

Decidiram duas princesas, irmãs, repetindo A lição martelada desde a infância!

Onde é que vamos enfiar essas princesas! À parte, eu manifestei humildes desejos, Só que em voz alta, Para que o Senhor exterminasse aquele espírito impuro,

Vazio, servil, de cega imitação;

Para que ele excitasse na alma de quem quer que fosse palavras e exemplos que nos impedissem, como em uma forte muralha,

E com deplorável náusea, das coisas estrangeiras ${ }^{\mathrm{cccc}}$.
Собрал вокруг себя род веча *

И сказывал, как снаряжался в путь

В Россию, к варварам, со страхом и слезами; Приехал - и нашел, что ласкам нет конца;

Ни звука русского, ни русского лица Не встретил: будто бы в отечестве, с рузьями;

Своя провинция. - Посмотришь, вечерком Он чувствует себя здесь маленьким царьком; Такой же толк у дам, такие же наряды...

Он рад, но мы не рады.

Умолк. И тут со всех сторон

Тоска, и оханье, и стон.

Ax! Франция! Нет в мире лучше края! -

Решили две княжны, сестрицы, повторяя Урок, который им из детства натвержен.

Куда деваться от княжен! -

Я одаль воссылал желанья

Смиренные, однако вслух,

Чтоб истребил Господь нечистый этот дух

Пустого, рабского, слепого подражанья;

Чтоб искру заронил он в ком-нибудь с душой, Кто мог бы словом и примером

Нас удержать, как крепкою вожжой,

От жалкой тошноты по стороне чужой. 
Podem me chamar de conservador,

Mas, para mim, cem vezes pior é o nosso

Norte

Que nesses tempos afastou tudo pela mudança, pelo novo modo.

Costumes, a língua, o passado sagrado,

As roupas majestosas - tudo em prol do outro

De estilo histriônico:

Uma cauda por detrás e na frente um decote maravilhoso,

Contra a razão, contra os costumes naturais, Movimentos embaraçados, rostos enfeados, Queixos engraçados, barbeados e cinzentos!

Vestidos e cabelos tão curtos quanto a inteligência!

$\mathrm{Ah}$ ! Se for para transgredirmos toda a nossa origem,

Que seja junto aos sábios chineses

Em sua ignorância aos estrangeiros.

Quando é que ressurgiremos dessa dominação?

Para ser sábio, bem disposto, nosso povo, Ainda que seja pela língua,

Não pode achar que somos alemães.

$<<$ Colocar lado a lado o europeu e o

nacional, que coisa mais estranha!>>

E como traduzir "madame" e mademoiselle"?

Que tal por "minha senhora"? >> pôs-se a resmungar alguém, para mim.

Imagine, todos se puseram a gargalhar,

Contra mim.

$<<$ Minha senhora! Ha! Ha! Ha! Ha!

Magnífico!
Пускай меня отъявят * старовером,

Но хуже для меня наш Север во сто крат

С тех пор, как отдал все в обмен на новый лад

И нравы, и язык, и старину святую,

И величавую одежду на другую

По шутовскому образцу:

Хвост сзади, спереди какой-то чудный выем,

Рассудку вопреки, наперекор стихиям;

Движенья связаны, и не краса лицу;

Смешные, бритые, седые подбородки!

Как платья, волосы, так и умы коротки!..

Ах! если рождены мы все перенимать,

Хоть у китайцев бы нам несколько занять

Премудрого у них незнанья иноземцев.

Воскреснем ли когда от чужевластья мод?

Чтоб умный, бодрый наш народ

Хотя по языку нас не считал за немцев.

"Как европейское поставить в параллель

С национальным - странно что-то!

Ну как перевести мадам и мадмуазель?

Ужли сударыня!!" - забормотал мне кто-то.

Вообразите, тут у всех

На мой же счет поднялся смех.

"Сударыня! Ха! ха! ха! ха! прекрасно! 


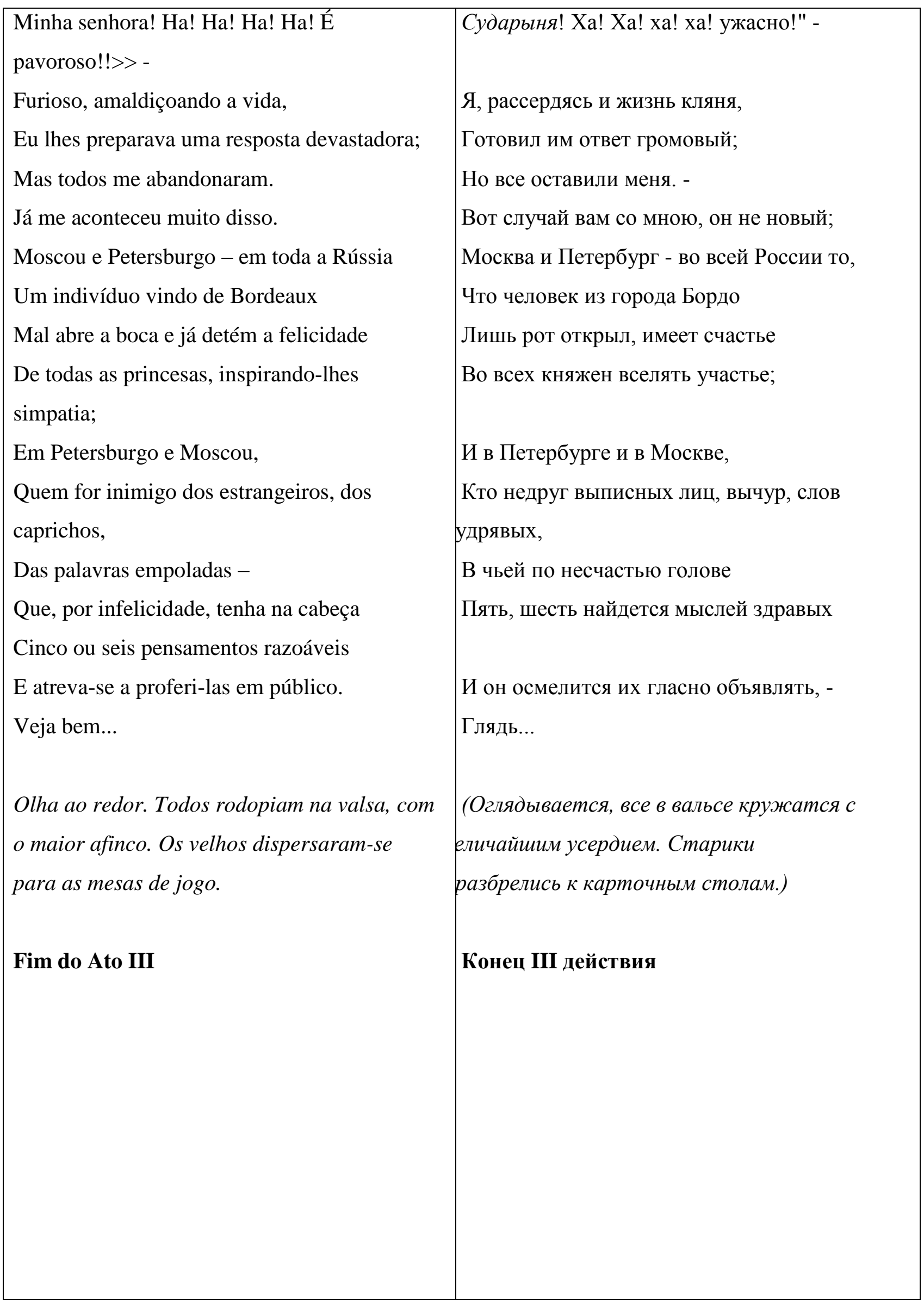




\section{ATO IV \\ No saguão principal da casa de Fámussov; uma grande escada que dá acesso ao segundo andar, e que se une a muitas galerias colaterais; abaixo, à direita (das personagens), há o terraço de entrada e o recinto do porteiro; à esquerda, de um lado, o quarto de Moltchálin. É noite. Iluminação tênue. Alguns criados estão atarefados, outros dormem à espera de seus senhores.}

\section{Cena 1}

Condessa-avó, Condessa-neta. Em frente, seus criados.

\section{Criado}

A carruagem da Condessa Khriúmina!

Condessa neta (enquanto coloca os casacos) Que baile! Ora essa, Fámussov! Que tipos teve de chamar!

São como monstros de outro mundo, Com os quais não se pode falar, e muito menos dançar.

\section{Condessa-avó}

Vamos, minha querida, eu, é claro, estou sem forças,

Um dia vou direto para a cova.

\section{ДЕЙСТВИЕ IV}

У Фамусова в доме парадные сени; большая естница из второго жилья, к которой примыкают многие побочные из нтресолей; внизу справа (от действующих лиц) выход на крыльцо и гвейцарская ложа; слева, на одном же плане, комната Молчалина. Ночь. Слабое свещение. Лакеи иные суетятся, иные спят в ожидании господ своих.

\section{Явление 1}

\section{Графиня бабушка, Графиня внучка,} переди их лакей.

\section{Лакей}

Графини Хрюминой карета!

Графиня внучка (покуда ее укутывают) Ну бал! Ну Фамусов! умел гостей назвать!

Какие-то уроды с того света, И не с кем говорить, и не с кем танцевать.

\section{Графиня бабушка}

Поетем, матушка, мне, прафо, не под силу,

Когда-нибуть я с пала та в могилу. 


\begin{tabular}{|c|c|}
\hline (Ambas saem.) & (Обе уезжают.) \\
\hline Cena 2 & Явление 2 \\
\hline Platón Mikháilovitch e Natália Dmítrievna. & Платон Михайлович и Наталья \\
\hline $\begin{array}{l}\text { Um criado, que está próximo a eles, anda } \\
\text { atarefado. O outro, na entrada, grita: }\end{array}$ & $\begin{array}{l}\text { митриевна. Один лакей около их хлопочет, } \\
\text { другой у подъезда кричит: }\end{array}$ \\
\hline A carruagem dos Góritch! & Карета Горича! \\
\hline Natália Dmítrievna & Наталья Дмитриевна \\
\hline Meu anjo, minha vida, & Мой ангел, жизнь моя, \\
\hline $\begin{array}{l}\text { Precioso, queridinho, Popóch, por que tal } \\
\text { desânimo? }\end{array}$ & $\begin{array}{l}\text { Бесценный, душечка, Попошь, что так } \\
\text { ныло? }\end{array}$ \\
\hline (beija o marido na boca.) & (Целует мужа в лоб.) \\
\hline Admita, o baile foi alegre. & Признайся, весело у Фамусовых было. \\
\hline Platón Mikháilovitch & Платон Михайлович \\
\hline $\begin{array}{l}\text { Natácha, minha queridinha, eu cochilei no } \\
\text { baile. }\end{array}$ & Наташа-матушка, дремлю на балах я, \\
\hline Detestei até a morte, & До них смертельный неохотник, \\
\hline Mas não me contrapus, pois sou seu servo. & А не противлюсь, твой работник, \\
\hline Estive atento durante a noite, por vezes & Дежурю за полночь, подчас \\
\hline Só para lhe satisfazer, mas não estou infeliz, & Тебе в угодность, как ни грустно, \\
\hline E deixo o comando em vantagem. & Пускаюсь по команде в пляс. \\
\hline Natália Dmítrievna & Наталья Дмитриевна \\
\hline Você finge e muito mal; & Ты притворяешься, и очень неискусно; \\
\hline Queria mesmo é ganhar a fama de velho. & Охота смертная прослыть за старика. \\
\hline (sai com o criado) & (Уходит с лакеем.) \\
\hline Platón Mikháilovitch (a sangue-frio) & Платон Михайлович (хладнокровно) \\
\hline
\end{tabular}




\begin{tabular}{|c|c|}
\hline O baile foi bom, as prisões é que são amargas; & Бал вещь хорошая, неволя-то горька; \\
\hline E quem casa é que se enreda! & И кто жениться нас неволит! \\
\hline Tendo dito, vai servir a quem interessa... & Ведь сказано ж, иному на роду... \\
\hline Criado (do terraço) & Лакей (с крыльи̧а) \\
\hline $\begin{array}{l}\text { Na carruagem do senhor, chamam-no } \\
\text { impacientemente. }\end{array}$ & В карете барыня-с, и гневаться изволит \\
\hline Platón Mikháilovitch (com um suspiro) & Платон Михайлович (со вздохом) \\
\hline Vou, já vou. & Иду, иду. \\
\hline (sai.) & (Уезжает.) \\
\hline Cena 3 & Явление 3 \\
\hline Tchátski e seu criado à frente. & Чацкий и лакей его впереди. \\
\hline Tchátski & Чацкий \\
\hline Grite, para que venham o quanto antes. & Кричи, чтобы скорее подавали. \\
\hline (O criado sai.) & (Лакей уходит.) \\
\hline O dia se foi, e com ele & Ну вот и день прошел, и с ним \\
\hline Todos os espectros, todo o vazio, & Все призраки, весь чад и дым \\
\hline As vãs esperanças que enchiam a minha alma. & Надежд, которые мне душу наполняли. \\
\hline $\begin{array}{l}\text { O que eu esperava? O que pensava encontrar } \\
\text { por aqui? }\end{array}$ & Чего я ждал? что думал здесь найти? \\
\hline $\begin{array}{l}\text { Onde está o encanto deste encontro? A } \\
\text { felicidade em vida? }\end{array}$ & $\begin{array}{l}\text { Где прелесть эта встреч? участье в ком } \\
\text { ивое? }\end{array}$ \\
\hline Um grito! Alegria! Abraços! - Bobagem. & Крик! радость! обнялись! - Пустое. \\
\hline No coche, a um certo destino, & В повозке так-то на пути \\
\hline A uma planície sem fim, sento-me ocioso. & Необозримою равниной, сидя праздно, \\
\hline À frente, tudo que é visível & Все что-то видно впереди \\
\hline
\end{tabular}




\begin{tabular}{|c|c|}
\hline É claro, azul, inigualável; & Светло, сине, разнообразно; \\
\hline $\begin{array}{l}\text { Uma hora passa, duas, o dia todo; e } \\
\text { entusiasmado, }\end{array}$ & И едешь час, и два, день целый; вот резво \\
\hline $\begin{array}{l}\text { Chego voando ao descanso: onde não há } \\
\text { olhares, }\end{array}$ & $\begin{array}{l}\text { Домчались к отдыху; ночлег: куда ни } \\
\text { зглянешь, }\end{array}$ \\
\hline Tudo é tão quieto, e a estepe é vazia e morta... & Все та же гладь, и степь, и пусто и мертво... \\
\hline Que lástima, não tenho mais forças! & Досадно, мочи нет, чем больше думать \\
\hline Não é mais possível pensar em ficar ${ }^{\text {dddd }}$. & ганешь. \\
\hline (O criado retorna.) & (Лакей возвращается.) \\
\hline Pronto? & Готово? \\
\hline Criado & Лакей \\
\hline O cocheiro não está em lugar algum. & Кучера-с нигде, вишь, не найдут. \\
\hline Tchátski & Чацкий \\
\hline Vá, encontre-o, não vou passar a noite aqui. & Пошел, ищи, не ночевать же тут. \\
\hline (O criado sai novamente.) & (Лакей опять уходит.) \\
\hline Cena 4 & Явление 4 \\
\hline $\begin{array}{l}\text { Tchátski, Repietilov (corre até a entrada e, } \\
\text { na mesma, tropeça. Endireita-se } \\
\text { rapidamente). }\end{array}$ & $\begin{array}{l}\text { Чацкий, Репетилов (вбегает с крыльца, при } \\
\text { амом входе падает со всех ног и поспешно } \\
\text { правляется). }\end{array}$ \\
\hline Repietilov & Репетилов \\
\hline Ufa! Escorreguei. Ah, meu Criador! & Тьфу! оплошал. - Ах, мой Создатель! \\
\hline Deixe-me esfregar os olhos. Onde? & Дай протереть глаза; откудова? приятель!.. \\
\hline $\begin{array}{l}\text { Meu caro!.. Amigo cordial! Amigo adorado! } \\
\text { Mon Cher! }\end{array}$ & Сердечный друг! Любезный друг! Mon cher! \\
\hline As zombarias são sempre para mim como & Вот фарсы мне как часто были петы, \\
\hline
\end{tabular}


cantos,

Que eu sou um tagarela, um supersticioso, um tolo;

Que eu vejo sinais em todos os

pressentimentos;

Agora... Vou lhe contar que corri aqui,

Como se soubesse que o veria e, de repente,

Tropecei as pernas na soleira

E caí com o corpo todo.

Perdoe-me, é preciso que ria de mim,

Diga que Repietilov conta lorotas, que

Repietilov é um imbecil,

E eu gosto de você, como em uma espécie de doença,

Um certo tipo de amor e paixão,

Eu estou pronto para jurar pela minha alma,

Que no mundo não se encontra um amigo como eu,

Tão fiel como eu;

Mesmo que eu tivesse de me privar da esposa, dos filhos,

Abandonado pelo mundo todo,

Morto neste lugar,

O Senhor prestes a me destruir...

\section{Tchátski}

Basta de tolices.

\section{Repietilov}

Você não gosta de mim, nada mais natural:

Com os outros, ajo de diversas maneiras,

Mas contigo, hesito tímido,

Sou patético, sou risível, sou ignorante, sou
Что пустомеля я, что глуп, что суевер,

Что у меня на все предчувствия, приметы;

Сейчас... растолковать прошу,

Как будто знал, сюда спешу,

Хвать, об порог задел ногою

И растянулся во весь рост.

Пожалуй, смейся надо мною,

Что Репетилов врет, что Репетилов прост,

А у меня к тебе влеченье, род недуга,

Любовь какая-то и страсть,

Готов я душу прозакласть,

Что в мире не найдешь себе такого друга,

Такого верного, ей-ей;

Пускай лишусь жены, детей,

Оставлен буду целым светом,

Пускай умру на месте этом,

Да разразит меня Господь...

\section{Чацкий}

Да полно вздор молоть.

\section{Репетилов}

Не любишь ты меня, естественное дело:

С другими я и так и сяк,

С тобою говорю несмело,

Я жалок, я смешон, я неуч, я дурак. 
um tolo.

\section{Tchátski}

Que depreciação mais estranha!

\section{Repietilov}

Vá, me critique, eu mesmo me amaldiçoo,

Quando penso como desperdicei o tempo!

Diga-me, que horas são?

\section{Tchátski}

É hora de estar na cama;

Se veio para o baile,

Já pode voltar.

\section{Repietilov}

Que baile? Irmão, há um lugar onde passamos

Todas as noites até os dias brancos,

Em um decoro forjado, sem escapar ao jugo.

Será que você leu? Há um livro...

\section{Tchátski}

E você, leu? Tarefa para mim,

Mas também para Repietilov?

\section{Repietilov}

Pode me chamar de vândalo:

Eu mereço este nome.

Eu valorizava pessoas insignificantes!

Eu mesmo sempre delirava com almoços e bailes!

Esqueci-me dos filhos! Enganei minha mulher!

Joguei! Perdi! Fui posto sob tutela do Estado!

\section{Чацкий}

Вот странное уничиженье!

\section{Репетилов}

Ругай меня, я сам кляну свое рожденье, Когда подумаю, как время убивал!

Скажи, который час?

\section{Чацкий}

Час ехать спать ложиться;

Коли явился ты на бал,

Так можешь воротиться.

\section{Репетилов}

Что бал? братец, где мы всю ночь до бела ня,

В приличьях скованы, не вырвемся из ига, Читал ли ты? есть книга...

\section{Чацкий}

А ты читал? задача для меня,

Ты Репетилов ли?

\section{Репетилов}

Зови меня вандалом:

Я это имя заслужил.

Людьми пустыми дорожил!

Сам бредил целый век обедом или балом!

Об детях забывал! обманывал жену!

Играл! проигрывал! в опеку взят указом! * 


\begin{tabular}{|c|c|}
\hline $\begin{array}{l}\text { Arranjei uma dançarina! E não estava } \\
\text { sozinha: }\end{array}$ & Танцовщицу держал! и не одну: \\
\hline Eram três ao mesmo tempo! & Трех разом! \\
\hline $\begin{array}{l}\text { Eu bebia até morrer! Não dormia antes das } \\
\text { nove da manhã! }\end{array}$ & Пил мертвую! не спал ночей по девяти! \\
\hline $\begin{array}{l}\text { Repudiava a tudo: as leis! A consciência! A } \\
\text { fé! }\end{array}$ & Все отвергал: законы! совесть! веру! \\
\hline Tchátski & Чацкий \\
\hline Escute! É uma mentira sem tamanho; & Послушай! ври, да знай же меру; \\
\hline Há que se safar desse desespero. & Есть от чего в отчаянье придти. \\
\hline Repietilov & Репетилов \\
\hline $\begin{array}{l}\text { Dê-me os parabéns, agora eu ando com uma } \\
\text { gente erudita!! }\end{array}$ & Поздравь меня, теперь с людьми я знаюсь \\
\hline $\begin{array}{l}\text { Por toda noite, do começo ao fim, não me } \\
\text { afastei deles. }\end{array}$ & С умнейшими!! - всю ночь не рыщу напролет. \\
\hline Tchátski & Чацкий \\
\hline Mas, por exemplo, e agora? & Вот нынче, например? \\
\hline Repietilov & Репетилов \\
\hline Só essa noite não conta, & Что ночь одна, - не в счет, \\
\hline $\begin{array}{l}\text { Mas em compensação, pergunto: onde eu } \\
\text { estava? }\end{array}$ & Зато спроси, где был? \\
\hline Tchátski & Чацкий \\
\hline Eu mesmo posso adivinhar. & И сам я догадаюсь. \\
\hline Talvez em algum clube? & Чай, в клубе? \\
\hline Repietilov & Репетилов \\
\hline No clube inglês. Vou fazer uma confissão: & В Английском. Чтоб исповедь начать: \\
\hline Eu estava em uma reunião animada. & Из шумного я заседанья. \\
\hline
\end{tabular}




\begin{tabular}{|c|c|}
\hline $\begin{array}{l}\text { Não fale nada, por favor, eu dei a minha } \\
\text { palavra. }\end{array}$ & Пожало-ста молчи, я слово дал молчать; \\
\hline $\begin{array}{l}\text { Nós temos uma sociedade, um grupo } \\
\text { misterioso, }\end{array}$ & У нас есть общество, и тайные собранья \\
\hline Às quintas. Um círculo secreto... & По четвергам. Секретнейший союз... \\
\hline Tchátski & Чацкий \\
\hline Ah! Irmão, eu temo. & Ах! я, братец, боюсь. \\
\hline Como? No clube? & Как? в клубе? \\
\hline Repietilov & Репетилов \\
\hline Justamente. & Именно. \\
\hline Tchátski & Чацкий \\
\hline Eis as medidas extraordinárias, & Вот меры чрезвычайны, \\
\hline $\begin{array}{l}\text { E vocês merecem ser expulsos com seus } \\
\text { mistérios. }\end{array}$ & Чтоб взашеи прогнать и вас, и ваши тайны. \\
\hline Repietilov & Репетилов \\
\hline Seus temores são infundados. & Напрасно страх тебя берет, \\
\hline $\begin{array}{l}\text { Em voz alta, falamos alto, ninguém sequer } \\
\text { compreende. }\end{array}$ & Вслух, громко говорим, никто не разберет. \\
\hline $\begin{array}{l}\text { Eu mesmo me engalfinho nas câmaras dos } \\
\text { jurados, }\end{array}$ & Я сам, как схватятся о камерах, присяжных, \\
\hline $\begin{array}{l}\text { E quando falam sobre Byron, e sobre as } \\
\text { matérias importantes, }\end{array}$ & О Бейроне , ну о матерьях важных, \\
\hline Só escuto, sem descerrar os lábios; & Частенько слушаю, не разжимая губ; \\
\hline $\begin{array}{l}\text { Eu sou incapaz de entender, irmão, e sei que } \\
\text { sou um tolo. }\end{array}$ & Мне не под силу, брат, и чувствую, что глуп. \\
\hline Ah! Alexandre! Você faltou conosco; & Ax! Alexandre! у нас тебя недоставало; \\
\hline $\begin{array}{l}\text { Ouça, querido, seja bonzinho, ainda que um } \\
\text { pouco; }\end{array}$ & $\begin{array}{l}\text { Послушай, миленький, потешь меня хоть } \\
\text { ало; }\end{array}$ \\
\hline Vamos agora; nós já estávamos de saída; & Поедем-ка сейчас; мы, благо, на ходу; \\
\hline
\end{tabular}




\begin{tabular}{|c|c|}
\hline Os tipos que lhe apresentarei & С какими я тебя сведу \\
\hline $\begin{array}{l}\text { Que gente!!... Já não se parecem nem um } \\
\text { pouco comigo! }\end{array}$ & $\begin{array}{l}\text { Людьми!!... Уж на меня нисколько не } \\
\text { охожи! }\end{array}$ \\
\hline $\begin{array}{l}\text { E que gente, mon cher! O sumo da juventude } \\
\text { erudita! }\end{array}$ & Что за люди, mon cher! Сок умной молодежи! \\
\hline Tchátski & Чацкий \\
\hline $\begin{array}{l}\text { Deus esteja com eles e contigo. Aonde irei me } \\
\text { enfurnar? }\end{array}$ & Бог с ними и с тобой. Куда я поскачу? \\
\hline $\begin{array}{l}\text { E para quê? Nessa noite impenetrável? Para } \\
\text { casa, eu quero dormir. }\end{array}$ & Зачем? в глухую ночь? Домой, я спать хочу. \\
\hline Repietilov & Репетилов \\
\hline $\begin{array}{l}\text { Ora! Deixe disso! Quem dorme hoje em dia? } \\
\text { E mais, sem reservas, }\end{array}$ & $\begin{array}{l}\text { Э! брось! кто нынче спит? Ну полно, без } \\
\text { релюдий }\end{array}$ \\
\hline $\begin{array}{l}\text { Decida-se, e nós!.. Nós temos... Uma gente } \\
\text { decidida, }\end{array}$ & Решись, а мы!.. у нас... решительные люди, \\
\hline Uma dúzia de cabeças fervilhantes! & Горячих дюжина голов! \\
\hline $\begin{array}{l}\text { Gritamos! Imagina o que são centenas de } \\
\text { vozes!.. }\end{array}$ & Кричим - подумаешь, что сотни голосов!.. \\
\hline Tchátski & Чацкий \\
\hline E para que vocês se enfurecem tanto? & Да из чего беснуетесь вы столько? \\
\hline Repietilov & Репетилов \\
\hline Nós agitamos, irmão, agitamos! & Шумим, братец, шумим! \\
\hline Tchátski & Чацкий \\
\hline Agitam? E só isso? & Шумите вы? и только? \\
\hline Repietilov & Репетилов \\
\hline $\begin{array}{l}\text { Agora não é o lugar e o momento para } \\
\text { explicar e não há tempo, }\end{array}$ & Не место объяснять теперь и недосуг, \\
\hline
\end{tabular}


Mas é um assunto de Estado:

Veja, não amadureceu ainda,

Do nada, é impossível.

Que gente! Mon Cher! Sem delongas

Eu lhe contarei uma história: em primeiro lugar, o príncipe Grigóri!!

Um perfeito esquisitão! Nos mata de rir!

Sempre do lado dos ingleses, cada traço nele é inglês ${ }^{\text {eeee }}$,

E assim ele fala como eles, por entre os dentes,

E, para manter o costume, corta o cabelo rente.

Você não o conhece? Oh! Precisa conhecê-lo. Um outro - Vorkúlov Ievdokím;

Já escutou como ele canta? Oh! É de admirar!

Ouça, meu caro, sobretudo

Há um trecho adorável:

“Ah! Non lasciarmi, no, no, no”. ffff

Ainda temos dois irmãos:

Liévon e Bórinka, prole milagrosa!

Sobre eles não há o que falar;

Mas se ordenassem chamar a um de gênio:

Udúchev Ipolít Markélitch!!!

Será que você já não leu algo em uma reunião dele? Ainda que uma partezinha?

Vá ler, irmão, mas ele não escreve nada;

Eis que essa gente versada não se frustra com nada,

E repetem: escreva, escreva, escreva;

No entanto, você pode encontrar nas revistas

Um trecho, um olhar, algo dele.

Que significa agora esse algo? - tudo;
Но государственное дело:

Оно, вот видишь, не созрело,

Нельзя же вдруг.

Что за люди! mon cher! Без дальних я историй

Скажу тебе: во-первых, князь Григорий!!

Чудак единственный! нас со смеху морит!

Век с англичанами, вся английская складка,

И так же он сквозь зубы говорит,

И так же коротко обстрижен для порядка.

Ты не знаком? о! познакомься с ним.

Другой - Воркулов Евдоким;

Ты не слыхал, как он поет? о! диво!

Послушай, милый, особливо

Есть у него любимое одно:

"А! нон лашьяр ми, но, но, но". *

Еще у нас два брата:

Левон и Боринька, чудесные ребята!

Об них не знаешь что сказать;

Но если гения прикажете назвать:

Удушьев Ипполит Маркелыч!!!

Ты сочинения его

Читал ли что-нибудь? хоть мелочь?

Прочти, братец, да он не пишет ничего;

Вот эдаких людей бы сечь-то,

И приговаривать: писать, писать, писать;

В журналах можешь ты, однако, отыскать

Его отрывок, взгляд и нечто.

Об чем бишь нечто? - обо всем; 
Todos sabem, nós iremos com ele até os dias obscuros.

Mas nós temos uma cabeça como nenhuma outra na Rússia,

Não é preciso nomeá-lo, reconhecerá pelo retrato:

Um bandido noturno, duelista,

Foi deportado para a Kamtcháka ${ }^{\text {gggg }}$, retornou aleuciano,

E não tem as mãos limpas;

Mas um homem erudito não pode ser um farsante.

Quando ele fala sobre a honra elevada, Incute-nos uma espécie de demônio:

Os olhos injetados de sangue, o rosto queimando,

Ele mesmo chora, e nós todos soluçamos.

Que gente, será que há quem as assemelhe?

Duvido...

Mas entre eles, eu, é claro, sou um medíocre,

Me distancio um tantinho, preguiçoso, é um horror imaginar!

No entanto, quando eu faço uma forcinha nas ideias,

Sento por um bom tempo, eu não costumo

ficar parado por muito tempo,

E como que por acaso, de repente, dou à luz a um trocadilho.

$\mathrm{Eu}$ tenho este pensamento para outros engatarem

E, em seis, forma-se um vaudeville,

Um dos seis se ocupa da música,

E os outros aplaudem, quando ela é
Bсе знает, мы его на черный день пасем.

Но голова у нас, какой в России нету,

Не надо называть, узнаешь по портрету:

Ночной разбойник, дуэлист,

В Камчатку сослан был, вернулся алеутом,

И крепко на руку нечист;

Да умный человек не может быть не плутом.

Когда ж об честности высокой говорит, Каким-то демоном внушаем:

Глаза в крови, лицо горит,

Сам плачет, и мы все рыдаем.

Вот люди, есть ли им подобные? Навряд...

Ну, между ими я, конечно, зауряд , Немножко поотстал, ленив, подумать ужас!

Однако ж я, когда, умишком понатужась,

Засяду, часу не сижу,

И как-то невзначай, вдруг каламбур рожу.

Другие у меня мысль эту же подцепят

И вшестером, глядь, водевильчик * слепят, Другие шестеро на музыку кладут, Другие хлопают, когда его дают. 


\begin{tabular}{|c|c|}
\hline apresentada. & \\
\hline Irmão, ria, pois é assim: & Брат, смейся, а что любо, любо: \\
\hline Deus não me premiou com a inteligência, & Способностями Бог меня не наградил, \\
\hline $\begin{array}{l}\text { Mas me deu um bom coração. Veja por que } \\
\text { sou gentil com essa gente, }\end{array}$ & Дал сердце доброе, вот чем я людям мил, \\
\hline Se eu minto, eles perdoam... & Совру - простят... \\
\hline Criado ( na entrada) & Лакей $(y$ подъезда) \\
\hline A carruagem de Skalozúb! & Карета Скалозуба! \\
\hline Repietilov & Репетилов \\
\hline De quem? & Чья? \\
\hline Cena 5 & Явление 5 \\
\hline Os mesmos e Skalozúb, que desce as escadas. & Те же и Скалозуб, спускается с лестницы. \\
\hline Repietilov (ao seu encontro) & Репетилов (к нему навстречу) \\
\hline Ah! Skalozúb, alma minha, & Ах! Скалозуб, душа моя, \\
\hline Espere, para onde vai? Faça o favor. & Постой, куда же? сделай дружбу. \\
\hline (aperta-o nos braços.) & (Душит его в объятиях.) \\
\hline Tchátski & Чацкий \\
\hline $\begin{array}{l}\text { Aonde é que eu vou me meter para fugir } \\
\text { deles! }\end{array}$ & Куда деваться мне от них! \\
\hline (Entra no recinto do porteiro.) & (Входит в швейцарскую.) \\
\hline Repietilov (para Skalozúb) & Репетилов (Скалозубу) \\
\hline $\begin{array}{l}\text { Há muito que os rumores acerca de você } \\
\text { cessaram, }\end{array}$ & Слух об тебе давно затих, \\
\hline $\begin{array}{l}\text { Disseram que você se dirigiu para o } \\
\text { regimento, à serviço. }\end{array}$ & Сказали, что ты в полк отправился на службу. \\
\hline Conhecem um ao outro? & Знакомы вы? \\
\hline
\end{tabular}


(busca Tchátski com os olhos)

Cabeça dura! Escapuliu! Pouco importa!

Eu não esperava encontrá-lo, vamos comigo

E agora! Não invente desculpas:

Na casa do príncipe Grigori agora há uma multidão do povo.

Verá, somos quarenta homens.

Ah! Quanta inteligência há por lá, irmão!

Conversam toda a noite, não se aborrecem,

Em primeiro lugar, vão lhe embebedar com champagne até cair,

E em segundo lugar, ensinam tais coisas,

Que, é claro, para nós nem há como imaginar.

\section{Skalozúb}

Deus me livre. Não me enganará com a ciência,

Se quiser, arranje outros,

Para o senhor e o príncipe Grigori darei um Feldfebel $^{\text {hhhh }}$,

Ele alinhará três fileiras para os senhores,

E se tentar objetar, vai apanhar!

\section{Repietilov}

Só pensa em serviço militar! Mon Cher, olhe para cá:

Eu poderia ter galgado graus, mas encontrei o fracasso,

Talvez, como ninguém;

Eu servia como um civil, enquanto

O Barão Von Klotz seria apontado como
(Ищет Чаџкого глазами)

Упрямец! ускакал!

Нет нужды, я тебя нечаянно сыскал,

И просим-ка со мной, сейчас без отговорок:

У князь-Григория теперь народу тьма,

Увидишь, человек нас сорок,

Фу! сколько, братец, там ума!

Всю ночь толкуют, не наскучат,

Во-первых, напоят шампанским на убой,

А во-вторых, таким вещам научат,

Каких, конечно, нам не выдумать с тобой.

\section{Скалозуб}

Избавь. Ученостью меня не обморочишь,

Скликай других, а если хочешь,

Я князь-Григорию и вам

Фельдфебеля в Волтеры дам,

Он в три шеренги вас построит,

А пикните, так мигом успокоит.

\section{Репетилов}

Все служба на уме! Mon cher, гляди сюда:

И я в чины бы лез, да неудачи встретил,

Как, может быть, никто и никогда;

По статской я служил, тогда

Барон фон Клоц в министры метил, 


\begin{tabular}{|c|c|}
\hline ministro & А я - \\
\hline E eu - & К нему в зятья. \\
\hline Me tornaria seu genro. & Шел напрямик без дальней думы, \\
\hline Fui sem rodeios, sem pensar duas vezes, & С его женой и с ним пускался в реверси, * \\
\hline Jogar cartas com sua mulher e com ele, & Ему и ей какие суммы \\
\hline Perdi uma certa importância & Спустил, что Боже упаси! \\
\hline Para ele e para ela, e que Deus abençoe! & \\
\hline $\begin{array}{l}\text { Ele vivia na Fontanka, e eu construí uma casa } \\
\text { ao redor, }\end{array}$ & Он на Фонтанке жил, я возле дом построил, \\
\hline Com colunas! Imensa! Quanto custou! & С колоннами! огромный! сколько стоил! \\
\hline Enfim, me casei com uma de suas filhas, & Женился наконец на дочери его, \\
\hline O dote, uma ninharia. Pelo serviço - nada. & Приданого взял - шиш, по службе - ничего. \\
\hline $\begin{array}{l}\text { Um sogro alemão, mas qual a vantagem } \\
\text { disso? }\end{array}$ & Тесть немец, а что проку? \\
\hline Veja, ele tinha receio de ser recriminado & Боялся, видишь, он упреку \\
\hline Por ajudar a família! & За слабость будто бы к родне! \\
\hline $\begin{array}{l}\text { Ora essa! Será que seu receio é maior do que } \\
\text { o meu? }\end{array}$ & Боялся, прах его возьми, да легче ль мне? \\
\hline $\begin{array}{l}\text { Todos os seus secretários eram grosseirões, } \\
\text { todos corruptos, }\end{array}$ & Секретари его все хамы, все продажны, \\
\hline Uma gentinha, uns verdadeiros bichos, & Людишки, пишущая тварь, \\
\hline $\begin{array}{l}\text { Todos saíram da nobreza, todos são } \\
\text { importantes hoje em dia, }\end{array}$ & Все вышли в знать, все нынче важны, \\
\hline Vá olhar no calendário. & Гляди-ка в адрес-календарь. \\
\hline $\begin{array}{l}\text { Ora bolas! O serviço e os graus são fardos - } \\
\text { tormentos da alma; }\end{array}$ & $\begin{array}{l}\text { Тьфу! служба и чины, кресты - души } \\
\text { ытарства; }\end{array}$ \\
\hline Alekséi Lakhmótiev diz, milagrosamente, & Лахмотьев Алексей чудесно говорит, \\
\hline Que os remédios radicais são indispensáveis, & Что радикальные потребны тут лекарства, \\
\hline $\begin{array}{l}\text { Um estômago não funciona bem por muito } \\
\text { tempo. }\end{array}$ & Желудок дольше не варит. \\
\hline (Pára ao perceber que Zagoriétski tomou o & (Останавливается, увидя, что Загорецкий \\
\hline lugar de Skalozúb, que saiu há um tempo.) & аступил место Скалозуба, \\
\hline & который покудова уехал.) \\
\hline
\end{tabular}




\section{Cena 6}

Repietilov, Zagoriétski

\section{Zagoriétski}

Queira continuar, confessa-se de maneira sincera,

Eu sou um tremendo liberal, como você!

O quanto já perdi

Por falar tão aberta e corajosamente!..

\section{Repietilov (com desgosto)}

Cada um foi para seu canto, sem dizer nem uma palavra;

Mal vi um, já se foi o outro.

Primeiro Tchátski, que logo se escondeu, e depois Skalozúb.

\section{Zagoriétski}

Que acha de Tchátski?

\section{Repietilov}

Ele não é um tolo,

Hoje eu dei com ele por aqui, só papo furado,

E a conversa produtiva começou pelo

vaudeville.

Sim! O vaudeville é algo a se falar, mas o resto é tudo bobagem.

Eu e ele... Nós... Temos os mesmos gostos.

\section{Zagoriétski}

E você notou que ele está seriamente louco?

\section{ЯВЛЕНИЕ 6}

Репетилов, Загорецкий.

\section{Загорецкий}

Извольте продолжать, вам искренно ризнаюсь,

Такой же я, как вы, ужасный либерал!

И от того, что прям и смело объясняюсь, Куда как много потерял!..

\section{Репетилов (с досадой)}

Все врознь, не говоря ни слова;

Чуть из виду один, гляди уж нет другого.

Был Чацкий, вдруг исчез, потом и Скалозуб.

\section{Загорецкий}

Как думаете вы об Чацком?

\section{Репетилов}

Он не глуп,

Сейчас столкнулись мы, тут всякие турусы, И дельный разговор зашел про водевиль.

Да! водевиль есть вещь, а прочее все гиль.

Мы с ним... у нас... одни и те же вкусы.

\section{Загорецкий}

А вы заметили, что он

В уме сурьезно поврежден? 


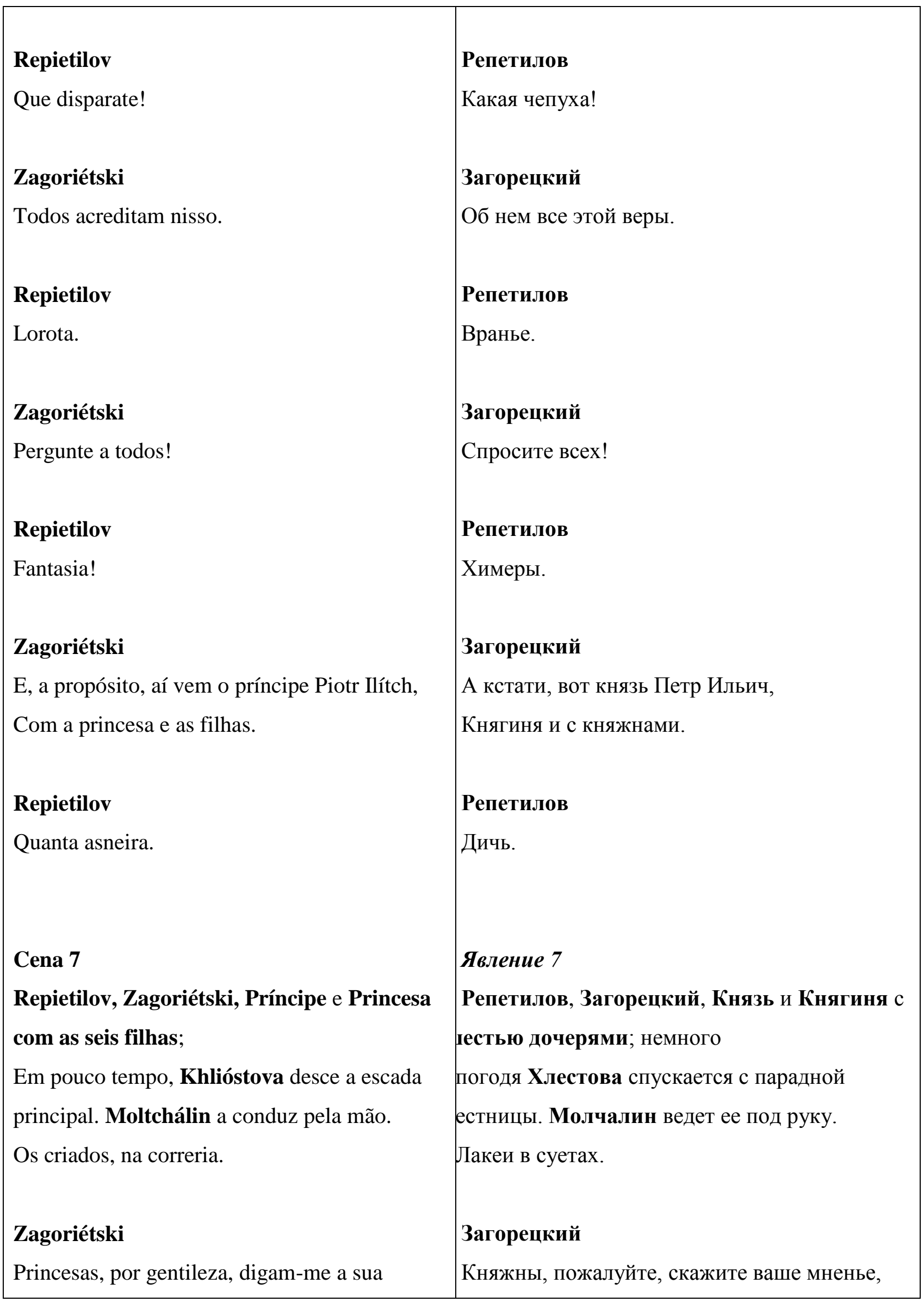




\begin{tabular}{|c|c|}
\hline opinião, & \\
\hline Tchátski é louco ou não? & Безумный Чацкий или нет? \\
\hline Primeira princesa & 1-я княжна \\
\hline Que tipo de dúvida há nisso? & Какое ж в этом есть сомненье? \\
\hline Segunda princesa & 2-я княжна \\
\hline O mundo inteiro sabe disso. & Про это знает целый свет. \\
\hline Terceira princesa & 3-я княжна \\
\hline $\begin{array}{l}\text { Os Drianskis, os Khvorovs, os Varlianskis, os } \\
\text { Skatchkovs. }\end{array}$ & Дрянские, Хворовы, Варлянские, Скачковы. \\
\hline Quarta princesa & 4-я княжна \\
\hline $\begin{array}{l}\text { Ah! Que são as velhas histórias frente às } \\
\text { novas? }\end{array}$ & Ax! вести старые, кому они новы? \\
\hline Quinta princesa & 5-я княжна \\
\hline Quem pode duvidar? & Кто сомневается? \\
\hline Zagoriétski & Загорецкий \\
\hline Mas vejam alguém que não acredita... & Да вот не верит... \\
\hline Sexta princesa & 6-я княжна \\
\hline O senhor! & Вы! \\
\hline Todas juntas & Все вместе \\
\hline Messiê Repietilov! O senhor! Messiê & Мсье Репетилов! Вы! Мсье Репетилов! что \\
\hline Repietilov! Como assim? & Ы! \\
\hline Ora essa! Será possível que o senhor está & Да как вы! Можно ль против всех! \\
\hline contra todos! & Да почему вы? стыд и смех. \\
\hline E por quê? É uma vergonha! & \\
\hline
\end{tabular}




\begin{tabular}{|c|c|}
\hline Repietilov (tapa os ouvidos) & Репетилов (затыкает себе уши) \\
\hline $\begin{array}{l}\text { Perdoem-me, eu não sabia que era um fato } \\
\text { assim tão conhecido. }\end{array}$ & Простите, я не знал, что это слишком гласно. \\
\hline Princesa & Княгиня \\
\hline $\begin{array}{l}\text { Ainda não seria conhecido se lhe falar não } \\
\text { fosse perigoso, }\end{array}$ & Еще не гласно бы, с ним говорить опасно, \\
\hline Há muito tempo trancado. & Давно бы запереть пора. \\
\hline Parece-lhe que até seu dedo mindinho & Послушать, так его мизинец \\
\hline $\begin{array}{l}\text { É mais inteligente que todos, até que o } \\
\text { príncipe Piotr! }\end{array}$ & Умнее всех, и даже князь-Петра! \\
\hline Eu acho que ele é simplesmente um jacobino, & Я думаю, он просто якобинец, \\
\hline Esse seu Tchátski!!! Vamos. Príncipe, o & Ваш Чацкий!!! Едемте. Князь, ты везти бы \\
\hline senhor poderia levar Kátich ou Zizi, & 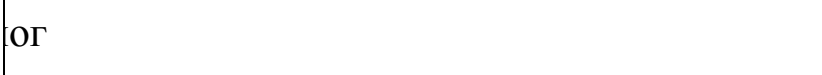 \\
\hline Nós sentaremos na carruagem de seis lugares. & Катишь или Зизи, мы сядем в шестиместной. \\
\hline Khlióstova (das escadas) & Хлестова (с лестниць) \\
\hline $\begin{array}{l}\text { Princesa, a senhora tem uma pequena dívida } \\
\text { das cartas. }\end{array}$ & Княгиня, карточный должок. \\
\hline Princesa & Княгиня \\
\hline Ficarei devendo, minha cara. & За мною, матушка. \\
\hline Todos (uns para os outros) & Bce $(\partial p y z \kappa ~ д р у г y)$ \\
\hline Adeus. & Прощайте. \\
\hline $\begin{array}{l}\text { (A família de príncipes sai e Zagoriétski } \\
\text { também.) }\end{array}$ & $\begin{array}{l}\text { (Княжеская фамилия * уезжает, и } \\
\text { агорецкий тоже.) }\end{array}$ \\
\hline Cena 8 & Явление 8 \\
\hline Repietilov, Khlióstova, Moltchálin & Репетилов, Хлестова, Молчалин. \\
\hline Repietilov & Репетилов \\
\hline
\end{tabular}




\begin{tabular}{|c|c|}
\hline Meu pai do céu! & Царь небесный! \\
\hline $\begin{array}{l}\text { Amfissa Nilovna! Ah! Tchátski! Pobre } \\
\text { coitado! Isso sim! }\end{array}$ & Амфиса Ниловна! Ах! Чацкий! бедный! вот! \\
\hline $\begin{array}{l}\text { Nossa grande inteligência! E mil } \\
\text { desassossegos! }\end{array}$ & Что наш высокий ум! и тысяча забот! \\
\hline $\begin{array}{l}\text { Diga-me, por que há tantas preocupações no } \\
\text { mundo!? }\end{array}$ & Скажите, из чего на свете мы хлопочем! \\
\hline Khlióstova & Хлестова \\
\hline Assim Deus quis; e, ademais, & Так Бог ему судил; а впрочем, \\
\hline Talvez haja tratamento e cura; & Полечат, вылечат авось; \\
\hline $\begin{array}{l}\text { Mas e você, meu paizinho, é incurável, não } \\
\text { presta para nada. }\end{array}$ & А ты, мой батюшка, неисцелим, хоть брось. \\
\hline Dignou-se a aparecer em tempo! - & Изволил вовремя явиться! - \\
\hline Moltchálin, vá para seu quartinho, & Молчалин, вон чуланчик твой, \\
\hline $\begin{array}{l}\text { Pouco importam as despedidas; Vá, e que } \\
\text { Deus esteja contigo. }\end{array}$ & Не нужны проводы; поди, Господь с тобой. \\
\hline (Moltchálin sai em direção ao seu quarto.) & (Молчалин уходит к себе в комнату.) \\
\hline $\begin{array}{l}\text { Adeus, meu amigo; vá tomar um pouco de } \\
\text { juízo. }\end{array}$ & Прощайте, батюшка; пора перебеситься. \\
\hline (sai.) & (Уезжает.) \\
\hline Cena 9 & ЯВЛЕНИЕ 9 \\
\hline Repietilov com seus criados. & Репетилов со своим лакеем. \\
\hline Repietilov & Репетилов \\
\hline Agora, que caminho seguir? & Куда теперь направить путь? \\
\hline Do crepúsculo ao amanhecer. & А дело уж идет к рассвету. \\
\hline Vamos, deixe-me sentar na carruagem, & Поди, сажай меня в карету, \\
\hline
\end{tabular}




\begin{tabular}{|c|c|}
\hline $\begin{array}{l}\text { Me leve para qualquer lugar. } \\
\text { (sai.) }\end{array}$ & $\begin{array}{l}\text { Вези куда-нибудь. } \\
\text { (Уезжает.) }\end{array}$ \\
\hline Cena 10 & Явление 10 \\
\hline O último candeeiro apaga-se. & Последняя лампа гаснет. \\
\hline Tchátski (sai do recinto do porteiro) & Чацкий (выходит из швейцарской) \\
\hline $\begin{array}{l}\text { Que é isso? E ouvi com os meus próprios } \\
\text { ouvidos! }\end{array}$ & Что это? слышал ли моими я ушами! \\
\hline Não há risos, mas claramente raiva. & Не смех, а явно злость. Какими чудесами? \\
\hline Com que tipo de milagre? & Через какое колдовство \\
\hline $\begin{array}{l}\text { Mediante que bruxaria todos repetiram } \\
\text { Em voz alta esse absurdo sobre mim! }\end{array}$ & Нелепость обо мне все в голос повторяют! \\
\hline E para uns é como se fosse um triunfo, & И для иных как словно торжество, \\
\hline Para outros, comiseração... & Другие будто сострадают... \\
\hline Oh! Se fosse possível penetrar nas pessoas: & О! если б кто в людей проник: \\
\hline O que nelas é pior? O espírito ou a língua? & Что хуже в них? душа или язык? \\
\hline Quem é que inventou isso? & Чье это сочиненье! \\
\hline $\begin{array}{l}\text { Acreditaram em asneiras e outros a } \\
\text { comunicaram, }\end{array}$ & Поверили глупцы, другим передают, \\
\hline $\begin{array}{l}\text { Num piscar de olhos, as velhas soaram um } \\
\text { alarme - }\end{array}$ & Старухи вмиг тревогу бьют - \\
\hline E eis a opinião geral! & И вот общественное мненье! \\
\hline E eis esta Pátria!... Não, na chegada hoje, & И вот та родина... Нет, в нынешний приезд, \\
\hline Eu vejo que essa Pátria logo me aborrece. & Я вижу, что она мне скоро надоест. \\
\hline E Sófia sabia disso? - É claro, contaram a ela, & А Софья знает ли? - Конечно, рассказали, \\
\hline Ela não deve ter se divertido & Она не то, чтобы мне именно во вред \\
\hline Mas, se é verdade ou não, & Потешилась, и правда или нет - \\
\hline Para ela tanto faz, se for eu, ou outro. & Ей все равно, другой ли, я ли, \\
\hline Ela não valoriza ninguém com sinceridade. & Никем по совести она не дорожит. \\
\hline $\begin{array}{l}\text { Mas e aquele desmaio, desfalecimento por } \\
\text { quê? }\end{array}$ & Но этот обморок, беспамятство откуда?? - \\
\hline
\end{tabular}


Ela é sensível e cheia de caprichos,

Qualquer coisa pode excitá-la -

Eu considerava isso um indício das vivas paixões.

Que nada, nem uma migalha:

Com certeza ela também desmaiaria

Se alguém pisasse no rabo de seu

Cachorrinho ou gatinho ${ }^{\text {iiii }}$.

Sófia (sobe as escadas do segundo andar, com uma vela)

Moltchálin, é você?

(rapidamente, de novo, a porta bate.)

\section{Tchátski}

Ela! Ela mesma!

Ah, a cabeça fervilha, todo o meu sangue está em agitação.

Apareceu! Não é ela! Será que é uma visão?

Será que realmente enlouqueci?

Eu estou como que pronto para o impensável;

Mas não é uma visão, é hora de uma visita convencional.

Para que me enganar?

Chamou a Moltchálin, aí está o seu quarto.

Seu criado (da entrada)

Carrua...

\section{Tchátski}

Shsh!
Нерв избалованность, причуда, -

Возбудит малость их, и малость утишит, Я признаком почел живых страстей. - Ни рошки:

Она конечно бы лишилась так же сил, Когда бы кто-нибудь ступил

На хвост собачки или кошки.

София (над лестницей во втором этаже, со вечкою)

Молчалин, вы?

(Поспешно опять дверь припирает.)

\section{Чацкий}

Она! она сама!

Ax! голова горит, вся кровь моя в волненьи.

Явилась! нет еe! неужели в виденьи?

Не впрямь ли я сошел с ума?

К необычайности я точно приготовлен;

Но не виденье тут, свиданья час условлен.

К чему обманывать себя мне самого?

Звала Молчалина, вот комната его.

Лакей его (с крыльц̧а)

Kape...

\section{Чацкий}

$\mathrm{Cc} !$ 


\begin{tabular}{|c|c|}
\hline (empurra-o de lá) & (Выталкивает его вон.) \\
\hline Vou ficar aqui até a manhã, & Буду здесь, и не смыкаю глазу, \\
\hline Sem nem ao menos piscar. & \\
\hline Se for para ver a desgraça, & Хоть до утра. Уж коли горе пить, \\
\hline Tanto melhor que seja logo, & Так лучше сразу, \\
\hline $\begin{array}{l}\text { Do que tardar. O infortúnio em vagar não } \\
\text { tortura. }\end{array}$ & Чем медлить, - а беды медленьем не избыть. \\
\hline A porta se abre. & Дверь отворяется. \\
\hline (esconde-se atrás da coluna.) & (Прячется за колонну.) \\
\hline Cena 11 & Явление 11 \\
\hline $\begin{array}{l}\text { Tchátski está escondido, Liza está com um } \\
\text { lampião. }\end{array}$ & Чацкий спрятан, Лиза со свечкой. \\
\hline Liza & Лиза \\
\hline Ah! Que canseira! Que medo. & Ах! мочи нет! робею. \\
\hline $\begin{array}{l}\text { Nessa entrada vazia! À noite! Tenho medo } \\
\text { dos duendes }{ }^{\mathrm{jjj}} \text {, }\end{array}$ & В пустые сени! в ночь! боишься домовых, \\
\hline E também dos vivos. & Боишься и людей живых. \\
\hline $\begin{array}{l}\text { A senhorinha está atormentada, vou deixar } \\
\text { como está, }\end{array}$ & Мучительница-барышня, Бог с нею, \\
\hline E Tchátski, uma eterna pedra no caminho; & И Чацкий, как бельмо в глазу; \\
\hline $\begin{array}{l}\text { Vejam, ela diz que o viu em algum lugar aqui } \\
\text { embaixo. }\end{array}$ & Вишь, показался ей он где-то здесь внизу. \\
\hline (olha ao redor.) & (Осматривается.) \\
\hline $\begin{array}{l}\text { Sim! Ora! Sua vontade é perambular pela } \\
\text { entrada! }\end{array}$ & Да! как же! по сеням бродить ему охота! \\
\hline Certamente, ele já se foi há muito, & Он, чай, давно уж за ворота, \\
\hline
\end{tabular}


O amor há-de se conservar até amanhã, Foi para casa: deitar e dormir.

A minha senhora mandou bater à porta do amado.

(bate à porta de Moltchálin.)

Vamos, vamos. Faça o favor de despertar. A senhorinha está te chamando.

Mais depressa, quer ser pego?

\section{Cena 12}

Tchátski, atrás da coluna, Liza, Moltchálin (espreguiça-se e boceja), Sófia (desce, sem fazer barulho).

\section{Liza}

O senhor é uma verdadeira pedra, um gelo.

\section{Moltchálin}

Ah! Lizanka, veio para cá por conta própria?

\section{Liza}

A senhorinha pediu, senhor.

\section{Moltchálin}

Quem adivinharia

Que nestas bochechas, nestas veias

As cores do amor ainda não despontaram!

Será que veio só para isso: trazer as ordens de outros?
Любовь на завтра поберег,

Домой, и спать залег.

Однако велено к сердечному толкнуться.

(Стучится к Молчалину.)

Послушайте-с. Извольте-ка проснуться.

Вас кличет барышня, вас барышня зовет.

Да поскорей, чтоб не застали.

\section{Явление 12}

Чацкий за колонною, Лиза, Молчалин тотягивается и зевает), София (крадется сверху).

Лиза

Вы, сударь, камень, сударь, лед.

\section{Молчалин}

Ах! Лизанька, ты от себя ли?

Лиза

От барышни-с.

\section{Молчалин}

Кто б отгадал,

Что в этих щечках, в этих жилках

Любви еще румянец не играл!

Охота быть тебе лишь только на посылках? 


\section{Liza}

E o senhor, em busca de uma noiva,

Não devia ficar aí nessa moleza, perdendo tempo;

Bonito e gentil é quem não come

E não dorme até o casamento.

\section{Moltchálin}

Que casamento? Com quem?

\section{Liza}

Pois com a senhorinha.

\section{Moltchálin}

Vamos,

Muitas esperanças pela frente,

Arrastemos o tempo sem casamento.

\section{Liza}

Ora essa, senhor! Mas a que outro senão o senhor

Foi designado como marido?

\section{Moltchálin}

Não sei. Esses tais pensamentos

Me dão um arrepio!

Pável Afanássitch

Pode nos pegar uma hora dessas,

Despedir, amaldiçoar!... E aí? Abriremos nossos corações?

Eu não vejo nada formidável em Sófia

Pávlovna. Que Deus dê a ela uma vida rica,

\section{Лиза}

А вам, искателям невест,

Не нежиться и не зевать бы;

Пригож и мил, кто не доест

И не доспит до свадьбы.

\section{Молчалин}

Какая свадьба? с кем?

Лиза

А с барышней?

\section{Молчалин}

Поди,

Надежды много впереди,

Без свадьбы время проволочим.

Лиза

Что вы, сударь! да мы кого ж

Себе в мужья другого прочим?

\section{Молчалин}

Не знаю. А меня так разбирает дрожь, И при одной я мысли трушу, Что Павел Афанасьич раз Когда-нибудь поймает нас, Разгонит, проклянет!.. Да что? открыть ли ушу?

Я в Софье Павловне не вижу ничего Завидного. Дай Бог ей век прожить богато, 


\begin{tabular}{|c|c|}
\hline Amava a Tchátski outrora, & Любила Чацкого когда-то, \\
\hline Passou a me amar, como a ele. & Меня разлюбит, как его. \\
\hline $\begin{array}{l}\text { Meu anjinho, eu queria nem que fosse pela } \\
\text { metade, }\end{array}$ & Мой ангельчик, желал бы вполовину \\
\hline Sentir por ela, o que sinto por você; & К ней то же чувствовать, что чувствую к тебе; \\
\hline Mas não, não adianta repetir, & Да нет, как ни твержу себе, \\
\hline Eu a vejo e não sinto nada. & $\begin{array}{l}\text { Готовлюсь нежным быть, а свижусь - и } \\
\text { ростыну. }\end{array}$ \\
\hline Liza (de lado) & София (в сторону) \\
\hline Que descaramento! & Какие низости! \\
\hline Tchátski (atrás da coluna) & Чацкий (за колонною) \\
\hline Canalha! & Подлец! \\
\hline Liza & Лиза \\
\hline E o senhor não tem vergonha disso? & И вам не совестно? \\
\hline Moltchálin & Молчалин \\
\hline O meu pai me legou: & Мне завещал отец: \\
\hline $\begin{array}{l}\text { Em primeiro lugar, agradar a todos sem } \\
\text { exceção - }\end{array}$ & Во-первых, угождать всем людям без изъятья \\
\hline Ao senhorio, onde tiver a ocasião de morar, & Хозяину, где доведется жить, \\
\hline Ao chefe, a quem terá de servir, & Начальнику, с кем буду я служить, \\
\hline Ao criado, que limpará as roupas, & Слуге его, который чистит платья, \\
\hline $\begin{array}{l}\text { Ao porteiro, ao zelador, para evitar qualquer } \\
\text { mal, }\end{array}$ & Швейцару, дворнику, для избежанья зла, \\
\hline Ao cachorro do zelador, para ser lhe afável. & Собаке дворника, чтоб ласкова была. \\
\hline Liza & Лиза \\
\hline $\begin{array}{l}\text { Vem cá, senhor, mas que grande legado o seu } \\
\text { pai lhe deixou! }\end{array}$ & Сказать, сударь, у вас огромная опека! \\
\hline
\end{tabular}




\begin{tabular}{|c|c|}
\hline Moltchálin & Молчалин \\
\hline E assim eu finjo amor & И вот любовника я принимаю вид \\
\hline Para desejo da filha de tal homem... & В угодность дочери такого человека... \\
\hline Liza & Лиза \\
\hline Que dá de comer e beber, & Который кормит и поит, \\
\hline E às vezes presenteia com graus? & А иногда и чином подарит? \\
\hline Mas chega, já falamos o bastante. & Пойдемте же, довольно толковали. \\
\hline Moltchálin & Молчалин \\
\hline $\begin{array}{l}\text { Vamos compartilhar o amor dessa nossa } \\
\text { desprezível beldade. }\end{array}$ & $\begin{array}{l}\text { Пойдем любовь делить плачевной нашей } \\
\text { рали. }\end{array}$ \\
\hline Deixe-me abraçá-la. & Дай обниму тебя от сердца полноты. \\
\hline (Liza não o deixa dar-lhe um abraço) & (Лиза не дается.) \\
\hline Por que ela não é você!? & Зачем она не ты! \\
\hline (Faz menção de sair, Sófia não deixa.) & (Хочет идти, София не пускает.) \\
\hline $\begin{array}{l}\text { Sófia (quase em sussurros; toda cena é à } \\
\text { meia voz) }\end{array}$ & $\begin{array}{l}\text { София (почти шепотом; вся сиена } \\
\text { полголоса) }\end{array}$ \\
\hline $\begin{array}{l}\text { Afaste-se, eu já ouvi o bastante, } \\
\text { Homem horrível! Eu tenho vergonha de mim, } \\
\text { Vergonha até das paredes. }\end{array}$ & $\begin{array}{l}\text { Нейдите далее, наслушалась я много, } \\
\text { Ужасный человек! себя я, стен стыжусь. }\end{array}$ \\
\hline Moltchálin & Молчалин \\
\hline Como assim!? Sófia Pávlovna... & Как! Софья Павловна... \\
\hline Sófia & София \\
\hline Nem mais uma palavra, por amor a Deus. & Ни слова, ради Бога, \\
\hline Cale-se, ou eu me decido... & Молчите, я на все решусь. \\
\hline
\end{tabular}




\begin{tabular}{|c|c|}
\hline $\begin{array}{l}\text { Moltchálin (joga-se de joelhos, Sófia o } \\
\text { repele) }\end{array}$ & $\begin{array}{l}\text { Молчалин (бросается на колена, София } \\
\text { тталкивает его) }\end{array}$ \\
\hline $\begin{array}{l}\text { Ah! Procure se lembrar! Não fique zangada, } \\
\text { veja bem!.. }\end{array}$ & Ах! вспомните! не гневайтеся, взгляньте!.. \\
\hline Sófia & София \\
\hline Eu não me lembro de nada, não me aborreça. & Не помню ничего, не докучайте мне. \\
\hline $\begin{array}{l}\text { Lembranças! Como elas são para mim uma } \\
\text { punhalada. }\end{array}$ & Воспоминания! как острый нож оне. \\
\hline Moltchálin (rasteja a seus pés) & Молчалин (ползает у ног ее) \\
\hline Me perdoe... & Помилуйте... \\
\hline Sófia & София \\
\hline Não seja ridículo, levante-se. & Не подличайте, встаньте. \\
\hline $\begin{array}{l}\text { Não quero explicações, eu sei a sua } \\
\text { explicação, }\end{array}$ & Ответа не хочу, я знаю ваш ответ, \\
\hline Mentirá... & Солжете... \\
\hline Moltchálin & Молчалин \\
\hline Tenha a bondade... & Сделайте мне милость... \\
\hline Sófia & София \\
\hline Não. Não. Não. & Нет. Нет. Нет. \\
\hline Moltchálin & Молчалин \\
\hline $\begin{array}{l}\text { Eu estava brincando, não disse nada exceto } \\
\text { que... }\end{array}$ & Шутил, и не сказал я ничего окроме... \\
\hline Sófia & София \\
\hline Me largue, eu digo, agora, & Отстаньте, говорю, сейчас, \\
\hline Eu vou acordar a todos em casa com um grito & Я криком разбужу всех в доме \\
\hline E eu vou arruinar a todos nós. & И погублю себя и вас. \\
\hline
\end{tabular}


(Moltchálin se levanta.)

Agora será como se eu não o conhecesse. Você não vai ousar e nem merecer esperar Minhas recusas, queixas, lágrimas;

Que a aurora aqui não mais o encontre.

Que nunca mais eu ouça algo sobre você.

\section{Moltchálin}

Seja como quiser.

\section{Sófia}

Caso contrário, eu vou contar

Toda a verdade ao paizinho, de desgosto.

Eu não vou poupar a mim e nem a minha honra.

Vá. Chega! Seja feliz!

Nos encontros comigo na calada da noite,

O senhor se comportava com mais timidez

Que quando nos encontrávamos durante o dia, Frente às pessoas, no dia-a-dia.

Você tem menos ousadia que mentiras.

Estou contente por ter descoberto tudo esta noite

E não há testemunhas a me criticarem abertamente

Como agora há pouco, quando desmaiei, Aqui Tchátski estava...

Tchátski (joga-se entre eles)

Ele está aqui, sua fingida!
(Молчалин встает.)

Я с этих пор вас будто не знавала.

Упреков, жалоб, слез моих

Не смейте ожидать, не стоите вы их;

Но чтобы в доме здесь заря вас не застала.

Чтоб никогда об вас я больше не слыхала.

\section{Молчалин}

Как вы прикажете.

\section{София}

Иначе расскажу

Всю правду батюшке, с досады.

Вы знаете, что я собой не дорожу.

Подите. - Стойте, будьте рады,

Что при свиданиях со мной в ночной тиши

Держались более вы робости во нраве,

Чем даже днем, и при людях, и въяве;

В вас меньше дерзости, чем кривизны души.

Сама довольна тем, что ночью все узнала:

Нет укоряющих свидетелей в глазах,

Как давиче, когда я в обморок упала, Здесь Чацкий был...

Чацкий (бросается между ними)

Он здесь, притворщица! 


\begin{tabular}{|c|c|}
\hline Liza e Sófia & Лиза и София \\
\hline Ah! Ah! & $\mathrm{Ax} ! \mathrm{Ax} !$ \\
\hline $\begin{array}{l}\text { (Liza deixa cair a vela, de susto; Moltchálin } \\
\text { vai se esconder em seu quarto) }\end{array}$ & $\begin{array}{l}\text { (Лиза свечку роняет с испугу; Молчалин } \\
\text { крывается к себе в комнату.) }\end{array}$ \\
\hline Cena 13 & Явление 13 \\
\hline Os mesmos, exceto Moltchálin. & Те же, кроме Молчалина. \\
\hline Tchátski & Чацкий \\
\hline Logo desmaiará, agora seria perfeito, & Скорее в обморок, теперь оно в порядке, \\
\hline Há um motivo mais importante agora, & Важнее давишной причина есть тому, \\
\hline Eis enfim a solução para o mistério! & Вот наконец решение загадке! \\
\hline E veja para quem eu me sacrificava! & Вот я пожертвован кому! \\
\hline Não sei como consegui conter a raiva! & Не знаю, как в себе я бешенство умерил! \\
\hline Olhava, via e não conseguia acreditar! & Глядел, и видел, и не верил! \\
\hline Pois o querido e esquecido & А милый, для кого забыт \\
\hline $\begin{array}{l}\text { Antigo amigo é horror e vergonha para } \\
\text { mulher - }\end{array}$ & И прежний друг, и женский страх и стыд, - \\
\hline $\begin{array}{l}\text { Esconder-se atrás da porta, temer o que virá } \\
\text { como resposta. }\end{array}$ & За двери прячется, боится быть в ответе. \\
\hline Ah! Como conceber a intriga do destino? & Ах! как игру судьбы постичь? \\
\hline Pessoas com a alma perseguida são flagelos! - & Людей с душой гонительница, бич! - \\
\hline E os Moltchálins deleitam-se no mundo! & Молчалины блаженствуют на свете! \\
\hline Sófia (coberta de lágrimas) & София (вся в слезах) \\
\hline Não continue, eu sou completamente culpada. & Не продолжайте, я виню себя кругом. \\
\hline $\begin{array}{l}\text { Mas quem poderia pensar que ele fosse tão } \\
\text { pérfido! }\end{array}$ & $\begin{array}{l}\text { Но кто бы думать мог, чтоб был он так } \\
\text { оварен! }\end{array}$ \\
\hline Liza & Лиза \\
\hline Um ruído! Barulho! Ah! Deus meu! A casa & Стук! шум! ах! Боже мой! сюда бежит весь \\
\hline
\end{tabular}




\begin{tabular}{|c|c|}
\hline toda corre para cá. & ом. \\
\hline O seu paizinho vai agradecer e muito. & Ваш батюшка вот будет благодарен. \\
\hline Cena 14 & Явление 14 \\
\hline $\begin{array}{l}\text { Tchátski, Sófia, Liza, Fámussov, uma } \\
\text { multidão de criados com velas. }\end{array}$ & $\begin{array}{l}\text { Чацкий, София, Лиза, Фамусов, толпа слуг } \\
\text { о свечами. }\end{array}$ \\
\hline Fámussov & Фамусов \\
\hline Aqui! Atrás de mim! Rápido! Rápido! & Сюда! за мной! скорей! скорей! \\
\hline Mais velas, lampiões! & Свечей побольше, фонарей! \\
\hline $\begin{array}{l}\text { Onde estão os duendes? Ora! Eu conheço a } \\
\text { todos! }\end{array}$ & Где домовые? Ба! знакомые все лица! \\
\hline Filha, Sófia Pavlovna! Desavergonhada! & Дочь, Софья Павловна! страмница! \\
\hline Sua descarada! Onde! E com quem! & Бесстыдница! где! с кем! Ни дать, ни взять \\
\hline Exatamente igual à mãe, minha falecida: & 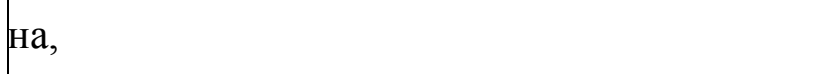 \\
\hline Mal nos separávamos - com homens já se & Как мать ее, покойница жена. \\
\hline metia & Бывало, я с дражайшей половиной \\
\hline E nem sei para onde ela ia! & Чуть врознь - уж где-нибудь с мужчиной! \\
\hline $\begin{array}{l}\text { Teme a Deus, como? Com o que ele a } \\
\text { cativou? }\end{array}$ & Побойся Бога, как? чем он тебя прельстил? \\
\hline De louco, você mesma o chamou! & Сама его безумным называла! \\
\hline $\begin{array}{l}\text { Não! Que estupidez minha em cair na } \\
\text { cegueira! }\end{array}$ & Нет! глупость на меня и слепота напала! \\
\hline $\begin{array}{l}\text { Toda essa conspiração, e ele mesmo estava na } \\
\text { conspiração, }\end{array}$ & Все это заговор, и в заговоре был \\
\hline $\begin{array}{l}\text { E todos os convidados! Para que eu estou } \\
\text { sendo tão castigado!.. }\end{array}$ & Он сам, и гости все. За что я так наказан!.. \\
\hline Tchátski (para Sófia) & Чацкий (Софии) \\
\hline Foi a senhorita que criou tal fantasia? & Так этим вымыслом я вам еще обязан? \\
\hline Fámussov & Фамусов \\
\hline
\end{tabular}


Irmão, não fique aí tergiversando, eu não vou ser enganado.

Ainda que discutamos, eu não posso crer.

E você, Filka, você é um completo

abobalhado,

Como porteiro se portou como um folgado.

Não percebe nada e nem sabe o que fazer.

Para onde você foi? Onde estava?

Por que a entrada não está fechada?

Como é que não examinou o pátio inteiro?

Como é que você não escutou direito?

Por este trabalho, deveria ser deportado:

Teria de vendê-lo a um preço baixo.

Você, espertinha, tudo por causa de suas travessuras;

Aí está a ponte Kuzniétski, suas ordens e princípios;

Lá você aprendeu a arranjar amantes,

Espere só, eu vou lhe corrigir:

Vai andar com os animais, marchar, em uma isbá;

E você, minha cara, não vou lhe deixar por aqui

Nem mais um dia, tenha paciência:

Não vai ficar em Moscou com mais ninguém;

Afastada desses espertalhões,

No campo, na casa de titia, nos confins do mundo, em Saratóv,

Lá você poderá se desolar por essa desolação,

Vai se sentar atrás do bastidor, bocejar ao ler as histórias dos santos.

Agora, meu senhor, eu só lhe peço
Брат, не финти, не дамся я в обман,

Хоть подеретесь, не поверю.

Ты, Филька, ты прямой чурбан,

В швейцары произвел ленивую тетерю,

Не знает ни про что, не чует ничего.

Где был? куда ты вышел?

Сеней не запер для чего?

И как не досмотрел? и как ты не дослышал?

В работу вас, на поселенье вас:

За грош продать меня готовы.

Ты, быстроглазая, все от твоих проказ;

Вот он, Кузнецкий мост, наряды и обновы;

Там выучилась ты любовников сводить,

Постой же, я тебя исправлю:

Изволь-ка в избу, марш, за птицами ходить;

Да и тебя, мой друг, я, дочка, не оставлю,

Еще дни два терпение возьми:

Не быть тебе в Москве, не жить тебе с юдьми;

Подалее от этих хватов,

В деревню, к тетке, в глушь, в Саратов,

Там будешь горе горевать,

За пяльцами сидеть, за святцами * зевать.

А вас, сударь, прошу я толком 
Para não mais nos visitar nem agora e nem nunca;

E sua última e derradeira palavra, É que, certamente, terá todas as portas fechadas:

Eu farei o máximo, eu, eu vou soar o alarme, Vou causar um alvoroço por toda a cidade E tornar tudo público:

Vou contar ao Senado, aos ministros, ao soberano.

\section{Tchátski (após um certo silêncio)}

Não criei juízo... Sou o culpado,

E mesmo vendo, não creio,

Como se todos ainda quisessem me explicar. Estou disperso pelos pensamentos... De que algo está à espera.

(Com fervor.)

Como fui cego! E em que procurei recompensa para todos os esforços! Apressei-me!... Voei! Trepidei! E pensei: a felicidade está próxima.

Frente a quem eu desperdicei belas palavras, Há pouco, tão terrível e vilmente!

Vejam só! Oh, meu Deus! Quem é que eu fui escolher?

Quando penso em quem a senhorita preferiu! Por que me seduziu com a esperança?

Por que não me disse na cara

Que transformou o passado em riso?
Туда не жаловать ни прямо, ни проселком;

И ваша такова последняя черта,

Что, чай, ко всякому дверь будет заперта:

Я постараюсь, я, в набат я приударю,

По городу всему наделаю хлопот

И оглашу во весь народ:

В Сенат подам, министрам, государю.

\section{Чацкий (после некоторого молчания)}

Не образумлюсь... виноват,

И слушаю, не понимаю,

Как будто все еще мне объяснить хотят.

Растерян мыслями... чего-то ожидаю.

(С жаром.)

Слепец! я в ком искал награду всех трудов!

Спешил!.. летел! дрожал! вот счастье, думал, лизко.

Пред кем я давиче так страстно и так низко Был расточитель нежных слов!

А вы! о Боже мой! кого себе избрали?

Когда подумаю, кого вы предпочли!

Зачем меня надеждой завлекли?

Зачем мне прямо не сказали,

Что все прошедшее вы обратили в смех?! 
Que nossos corações não estavam em mesmo movimento,

Que até a lembrança destes sentimentos -

Que em mim não esfriou e nem vislumbra o fim

Sem distração, sem transformação - lhe era odiosa?

Eu respirava, vivia com esta lembrança,

O tempo todo debruçado nela!

Tivesse dito que minha chegada lhe era repentina,

A minha visão, minhas palavras, atos - tudo repugnante, -

Eu, no mesmo instante, lhe privaria de minha convivência

E frente a isso, nos separaríamos para sempre.

Eu não ficaria tanto a cogitar,

Que era este homem o seu amado...

(Maliciosamente.)

Vai se reconciliar com ele, depois de uma madura reflexão.

Fica aí se destruindo, e para quê!

Pense, a senhorita sempre poderá

Cuidá-lo, paparicá-lo, mandá-lo para tudo quanto é canto.

Marido-menino, marido-criado, um pajem das mulheres -

O grande ideal de todos os maridos moscovitas.

Basta disso!... Eu me orgulho de romper com você.
Что память даже вам постыла

Тех чувств, в обоих нас движений сердца тех,

Которые во мне ни даль не охладила,

Ни развлечения, ни перемена мест.

Дышал, и ими жил, был занят беспрерывно!

Сказали бы, что вам внезапный мой приезд,

Мой вид, мои слова, поступки - все противно,

Я с вами тотчас бы сношения пресек

И перед тем, как навсегда расстаться,

Не стал бы очень добираться,

Кто этот вам любезный человек?..

(Насмешливо.)

Вы помиритесь с ним, по размышленьи релом.

Себя крушить, и для чего!

Подумайте, всегда вы можете его

Беречь, и пеленать, и спосылать за делом.

Муж-мальчик, муж-слуга, из жениных пажей

Высокий идеал московских всех мужей. -

Довольно!.. с вами я горжусь моим разрывом. 
E o senhor pai, o senhor, apaixonado por graus:

Eu desejo que cochile nessa deliciosa ignorância,

Eu não o ameaçarei com propostas insistentes de casamento.

Encontrará um outro, homem de negócios

Bem educado e servil,

Com mérito, enfim,

Ele será igual ao futuro sogro.

Assim seja! Eu estou completamente perdido.

Os sonhos se foram - o véu caiu;

Agora não me sentiria mal em estar ao lado

Da filha e do pai,

E do amante-imbecil,

E para todo o mundo descarregarei toda a bílis

e todo o desgosto.

Com quem me meti! Aonde o destino me jogou!

Todos correm, um atrás do outro ${ }^{\mathrm{kkkk}}$ !

Todos se amaldiçoam! Uma multidão de desalmados,

Traidores no amor, incansáveis na hostilidade,

Boateiros indômitos,

Pensadores desajeitados, idiotas maliciosos,

Velhas sinistras, velhos tornando-se

decrépitos

Sob a invencionice, o absurdo.

Os senhores me puseram, em pleno coro, a fama de louco.

Estão corretos: aquele que sai ileso do fogo,

Bem sucedido, após um dia transcorrido aqui,

Há de respirar o ar sozinho,
А вы, сударь отец, вы, страстные к чинам:

Желаю вам дремать в неведеньи счастливом,

Я сватаньем моим не угрожаю вам.

Другой найдется, благонравный, Низкопоклонник и делец, Достоинствами, наконец,

Он будущему тестю равный.

Так! отрезвился я сполна,

Мечтанья с глаз долой - и спала пелена;

Теперь не худо б было сряду

На дочь и на отца

И на любовника-глупца,

И на весь мир излить всю желчь и всю осаду.

С кем был! Куда меня закинула судьба!

Все гонят! все клянут! Мучителей толпа,

В любви предателей, в вражде неутомимых, Рассказчиков неукротимых, Нескладных умников, лукавых простяков, Старух зловещих, стариков,

Дряхлеющих над выдумками, вздором, Безумным вы меня прославили всем хором.

Вы правы: из огня тот выйдет невредим, Кто с вами день пробыть успеет, Подышит воздухом одним, 


\begin{tabular}{|c|c|}
\hline Com a razão intacta. & И в нем рассудок уцелеет. \\
\hline $\begin{array}{l}\text { Eu vou é fugir de Moscou! Não volto mais } \\
\text { para cá. }\end{array}$ & Вон из Москвы! сюда я больше не ездок. \\
\hline $\begin{array}{l}\text { Vou correr, sem olhar para trás, a buscar no } \\
\text { mundo }\end{array}$ & Бегу, не оглянусь, пойду искать по свету, \\
\hline Um cantinho para o sentimento ofendido! $!^{1111} .$. & Где оскорбленному есть чувству уголок!.. \\
\hline Que venha a carruagem, a carruagem! & Карету мне, карету! \\
\hline (sai.) & (Уезжает.) \\
\hline Cena 15 & Явление 15 \\
\hline Exceto Tchátski. & Кроме Чацкого \\
\hline Fámussov & Фамусов \\
\hline E o que foi isso? Não vê que ele enlouqueceu? & Ну что? не видишь ты, что он с ума сошел? \\
\hline Diga seriamente: & Скажи сурьезно: \\
\hline Louco! Quantas bobagens ele disse por aqui! & Безумный! что он тут за чепуху молол! \\
\hline Servil! Sogro! E como foi terrível com & Низкопоклонник! тесть! и про Москву так \\
\hline Moscou! & розно! \\
\hline E você, mocinha, decidiu acabar comigo? & А ты меня решилась уморить? \\
\hline $\begin{array}{l}\text { Será que o meu destino já não é deplorável o } \\
\text { bastante? }\end{array}$ & Моя судьба еще ли не плачевна? \\
\hline Ah! Meu Deus! E a princesa, & Ах! Боже мой! что станет говорить \\
\hline Que dirá Maria Aliekseievna? & Княгиня Марья Алексевна! \\
\hline Fim & Конец \\
\hline$<1822-1824>$ & $|<1822-1824\rangle$ \\
\hline
\end{tabular}




\section{Notas à tradução de Gorie ot uma, de Aleksandr Griboiédov}

\section{ATO I}

- Liza/Lizanka/Lizonka - nome comum em Khlmienitski e nos diversos autores franceses Marivaux, Gresset e Piron, onde aparecem diversas Lizettes atrevidas. Há possível paralelo entre Liza e Sacha, a empregada de Ólienka, em Urok koketkam, ili Lipietskie vody (Lição para Coquetes, ou A estância Lipietski). A personagem Liza é esperta e, em suas falas, há grande teor de uma comicidade inteligente. As atrizes que vieram a interpretá-la, no final do século XIX, não compreendiam como uma serva camponesa poderia ser tão desinibida, esperta, de falas argutas e pensamentos mordazes. No entanto, a tradição das diversas Lizettes atrevidas já era comum no repertório neoclássico. "Liza era, certamente, direcionada para a bela Aleksandra Assienkova (a mãe da ainda mais famosa Varvara Assienkova), que criou o papel importante da criada Sacha em Urok koketkam, ili Lipietskie vody (Lição para Coquetes, ou A estância Lipietski) e, para os próximos quinze anos, especializada em papéis de soubrette do repertório neoclássico. As atrizes do final do século XIX e início do XX, tais como Maria Lilina, a mulher de Stanislávski, que não conhecia a tradição soubrette da comédia neoclássica (que, na Rússia, retornou nas comédias com Lúkin e Kniájnin), não sabia o que fazer com Liza: Como pode Griboiédov construir uma criada, uma serva camponesa, tão desinibida e espirituosa?" (KARLINSKY, Simon. Russian drama: from its beginning to the age of Pushkin. Califórnia: University of Carolina Press, 1985., p. 300, trecho tradução nossa).

- Что-с? - a partícula "-c" ("-s") provém do termo Сударь (Sudar'), senhor. Em sua forma abreviada, o termo quer subentender subserviência para quem a mensagem é direcionada. Não há 
tradução exata para o português da partícula, sendo assim, preferiuse aqui a escolha da tradução pelo termo completo.

- Sófia - do grego, sabedoria. É um nome muito comum às heroínas de dramaturgos da época, tais como: Fonvízin, Kapnist, Kokoschkin e muitos outros. Diferente de Célimene, de Le misanthrope, Sófia não é sábia o bastante e parece apenas carregar as paixões da mesma maneira com que escolhe roupas e coisas na Ponte Kuzniétski. Em um primeiro momento, ela as adora e, depois, joga fora.

- Амур - na transliteração direta "Amur" - Liza refere-se a amour, em francês. Amur também pode referir-se à figura mitológica do Cupido. Decidiu-se pela manutenção do termo amur, da maneira errônea com que é mencionado por Liza que, certamente, imita a linguagem de seus superiores - a alta sociedade russa, acostumada a colocar o francês nos discursos cotidianos.

- Переведу часы (Perieviedu tchasy) - Liza alterará as horas, mudando os ponteiros com as próprias mãos.

- Fámussov - o nome provém, segundo Iúri Tyniánov, do termo FAMOUS. Isso se refere fortemente ao conteúdo da obra e, principalmente, ao caráter de notoriedade tão necessário a figuras como as que Fámussov deseja impetrar para si (Сюжет Горя от Ума, Siujet Goria ot uma, de Iuri Tyniánov): um homem genuinamente ocupado com questões que o fazem ou não se destacar em meio à sociedade. Todas as suas ações convergem para essa busca universo irrevogável e indelével das aparências. Como muitas das personagens da peça (Khlióstova, Repietilov), Fámussov também é um modelo baseado em alguém de fama já conhecida na Moscou da época: " A modelação, por parte de Griboiédov, de diversos de seus personagens em pessoas reais bem conhecidas em Moscou na época 
era também uma prática popular no tempo de Sumarókov e Nikóliev, mas prática que os dramaturgos russos abandonaram no final do século XVIII. Em sua carta, longamente citada, a Katenin, Griboiédov defende seu direito como comediante a desenhar retratos de pessoas reais em suas peças, pois os retratos não deteriorariam em caricaturas". (Karlinsky, 1985, cit., p. 300)

-Quando encontramos a Tatiana, de Evguiéni Oniéguin, pela primeira vez, vemos sua preferência pelos autores franceses e ingleses: "Imaginando-se heroína/De seus autores bem-amados - /Clarissa, Júlia e até Delfina - /Calma, Tatiana erra em seus prados,/Só, com suspeito livro à mão;/Nele procura e acha então/Secreto brilho e devaneio,/Que brotam fundo de seu seio;" (PUCHKIN, Alieksandr. Eugênio Oneguin. trad. Dário Moreira de Castro Alves. Moscou: Grupo Editorial <<Azbooka-Atticus>>, 2008, Capítulo III - X, página 134-35)

- Счастливые часов не наблюдают (Chástlivye tchisov nie nabliudaiut) - a frase tornou-se aforismo na língua russa, literalmente: "Os felizes não notam as horas".

- Moltchálin - do verbo "молчать" (moltchat) - calar/silenciar. É a figura servil e adequada a uma sociedade restrita às aparências e afável à imutabilidade. Figuras como Moltchálin são as mais desejáveis, pois são engrenagens hábeis no serviço imprescindível de manutenção do status quo. Essa característica, impressa no nome e na postura de Moltchálin, perante a alta sociedade não é ressaltada em sociedade e apenas surge com força nas falas de Tchátski que relembra, inicialmente com jocosidade: "Onde ele está, a propósito? Será que ele ainda não rompeu o selo do silêncio?" E após a descoberta do amor de Sófia por Moltchálin: "Lá vem ele, de 
mansinho, sem muitas palavras: que feitiço ele jogou em seu coração?"/(...) "E os Molchálins deleitam-se no mundo!".

-A Ponte Kuznietski é localizada no centro de Moscou. No século XIX, nela concentravam-se muitas lojas, confeitarias e livrarias, sendo seus comerciantes, em sua maioria, franceses.

- A idealização da Rússia para com os costumes europeus sofreu um grande terremoto após a revolução francesa de 1789. O terror promovido pelos jacobinos diminuiu a crença da Rússia na França como uma força de progresso e esclarecimento. A França passou a ser signo da inconstância e, sendo assim, quando Fámussov refere-se à liberalidade de Sófia, ele atribui toda a responsabilidade à sua ligação com os franceses e sua influência. (FIGES, Orlando.

Natasha's Dance: a cultural history of Rússia. New York: Picador, 2002, pp. 50-66).

- Refere-se a uma governanta estrangeira, contratada para cuidar dos filhos da nobreza.

- Скоморох - Skomorokh. Na Rússia antiga, eram atores/músicos populares ambulantes. Trata-se também de indivíduo que distrai os outros com brincadeiras/artifícios cômicos. Por essa última interpretação, decidiu-se pela escolha do termo "palhaços", em português.

- Cargo Civil de Oitavo Grau de acordo com a Tabela de Cargos introduzida por Pedro, o Grande. É equivalente ao grau de Major no Exército.

- Pequena cidade russa. 
- O enredo que Sófia conta assemelha-se às narrativas folclóricas russas do século XVIII, leitura que, certamente, ela está familiarizada - monstros diabólicos, fantasmas, amor, gritos. A personagem Tatiána, de Evguiéni Oniéguin: "Então falemos, certamente/O que vivi ficou na mente,/ Verdade e lendas, invenções/Sobre donzelas e visões/Do Demo: tudo se ensombrou,/O que eu sabia foi-se ao vento,/Então chegou um mau momento!" (Evguiéni Oniéguin, Capítulo três - XIX, cit.).

- "дурен сон" ("durien son") - supersticiosos, os russos acreditavam que os sonhos pudessem conter elementos premonitórios e ao ouvir o sonho de Sófia, Fámussov concorda com a gravidade do que é apresentado. No entanto, ele recua ao suspeitar das intenções de Sófia: "Se não fosse uma invenção". Ele concorda com o peso do sonho narrado, mas como ele não passa de um ludíbrio elaborado por Sófia, ele logo muda de assunto.

- "Ни во веки веков" ("Ni vo vieki viekov") - In seculo seculorum Liza utiliza-se da citação bíblica para enfatizar a impossibilidade do amor de Sófia por Moltchálin. A sensação de exagero provocada pela citação dá uma tonalidade bastante cômica à fala de Liza.

- Para explicar a aparente liberdade com que Liza discute os assuntos pessoais de Sófia, Belínski interpretou que ela assim o fazia por saber do caso amoroso de sua senhora e, sendo assim, tendo-a em seu poder: "Em geral, a criada trata sua senhora de igual para igual porque, como ajudante em seu relacionamento ilícito, mantém seu destino nas mãos" (Belínski, 1839,cit., trecho em tradução nossa).

- Sua gente, seus amigos - referência à camaradagem tão comum aos círculos dos dezembristas. Havia um culto de irmandade entre eles - "expande-se em um culto ao coletivo, que se tornaria tão 
importante para a vida política da intelligentsia russa". (Figes, 2002, cit., p. 81 , trecho em tradução nossa)

- A peça Urok koketkam, ili Lipietskie vody (Lição para Coquetes, ou A estância Lipietski) de Chakhovskói, passa-se em uma estação de águas, em Tambov. Na época, século XIX, era muito recorrente a existência dessas estações para cura de doenças. Esse é o primeiro indício na peça de que más línguas já mencionam Tchátski e que muito já se diz acerca de sua saúde e, no caso, de sua sanidade mental.

- Similar aos versos da Condessa Lelieva, em Urok koketkam, ili Lipietskie vody (Lição para Coquetes, ou A estância Lipietski), no Ato III: "Притом же Пронский добр доверчив тих - и точно/ Безгласым мужем быть на свет рожден нарочно,/ Так буду я над ним и в доме госпожой."

-A chegada de Tchátski é relembrada nos versos de Oniéguin: "(...)A viagem trouxe abatimento - /No mundo sempre acontecia./E, como Tchátski, apenas vindo,/Do barco ao baile ia subindo." (Evguiéni Oniéguin, Capítulo VIII, XIII, cit., p.371)

-O nome, em princípio, da personagem, era Чадский (Tchadski). Muito se questiona acerca de sua origem. A palavra Чад (Tchad), em russo, significa fumaça e, sendo assim, muitos estudiosos da obra (Medvedieva) referiram a possível origem do nome ao caráter efêmero, inconstante - como uma fumaça - que a personagem demonstra no decorrer da peça. Segundo Tyniánov, como veremos na sequência ao presente trabalho, o nome vem de Tchaadaiev.

- Verso muito famoso no linguajar russo. Semelhante à fala de peça precursora a Горе от ума (Gorie ot uma) - Урок кокетам или 
липецкие воды (Lição para Coquetes, ou A estância Lipietski), de Chakhovskoi. É a fala de Ólguin, primo de Pronski, uma das figuras amorosas da peça - influência direta para Griboiédov. "Ольгин (оглядываясь) - Здесь не видно, Так я у ваших ног. (становится почти на колени)" - "Ólguin (olha ao redor) - Não está claro, então eu estou aos seus pés (põe-se quase de joelhos)" - Cena 7 - Ato 5 (comédia em cinco atos, em versos).

- Medida russa equivalente a 1067 m, ou seja, um pouco mais que 1 quilômetro.

- Antigo jogo de cartas. O jogo constava de 32 cartas e podia compreender dois, três, às vezes quatro jogadores.

- Do russo альбом (albom) - comuns à sociedade da época, esses caderninhos eram usados para colocarem poemas e aforismos favoritos.

- O clube inglês - uma espécie de academia moscovita, que Griboiédov costumava frequentar com seu tio. Tolstói descreve, em Guerra e Paz, que os membros mais típicos do Clube eram pessoas mais velhas e respeitadas, com rostos autoconfiantes, dedos gordos, e gestos e vozes resolutas. (KELLY, Laurence. Diplomacy and Murder in Tehran: Alexander Griboyedov and Imperial Russia's Mission to the Shah of Persia. London: I.B. Tauris Publishers, 2002. p.13).

- Verso tirado do poema A harpa, de Gavril Románovitch Derjávin: "Мила нам добра весть о нашей стороне:/Отечества и дым нам сладок и приятен." Por sua vez, a frase provém do provérbio latino Et fumus patriae dulcis. 
- Catarina Primeira reinou de 1721 a 1725. Como é patente em toda a peça, Tchátski satiriza o passado arcaico e, sendo assim, coloca a tia de Sófia como descendente direta dessa época, ainda que o reinado de Catarina I fosse um século antes da época em que a peça foi escrita.

- No russo, Guillome.

- Após o incêndio de Moscou, muitas famílias foram para a cidade de Nijni-Novgorod (Figes, 2002, cit.). Sendo assim, a fala de Tchátski imprime a voz inventada pelos moscovitas: um misto de NijniNovgorod com França.

- Tchátski aqui fala sobre a preocupação da chamada geração dos filhos de 1812 em conformar-se em uma língua una, que fosse compreendida por todos e, principalmente, pelo povo. Há aí todo o trabalho de criação de toda uma língua escrita, tendo Púchkin como um dos maiores representantes. "(...) e buscou formar uma lingual escrita que falasse a todos. Os dezembristas tomaram parte central em sua filosofia (...). A criação de uma língua nacional parecia, aos veteranos de 1812, um meio de promover o espírito do campo de batalha e de criar uma nova nação com o homem comum. "Para conhecer nosso povo", escreveu o poeta dezembrista Aleksandr Bestujev, "há que se viver com eles e falar com eles em sua língua, há que se comer com eles e celebrar com eles em seus dias de festa" (Kelly, 2002, cit.).

- Uma das primeiras contraposições irônicas de Tchátski à figura de Moltchálin. Por estar animado frente à presença de sua amada, Tchátski não para de falar. Mas, mesmo assim, compara a sua tolice falatória com o silêncio de Moltchálin (falante/Moltchálin). 
- "Não apenas o jovem dândi falavam em uma lingual estrangeira com os russos mais velhos (...), ele também vivia sob o código moral estrangeiro, que ameaçava as tradições patriarcais da Rússia". (Figes, 2002, cit, p.52, trecho em tradução nossa).

\section{ATO II}

- Calendário eclesiástico muito comum na Rússia Antiga месяцеслов (miessiatselov). Nele, há os dias dos santos, feriados.

- Пономарь (Ponomar') - grau mais baixo na hierarquia da igreja. Literalmente: "Não leia assim, como se fosse um sacristão", tornouse proverbial na língua russa.

- Fámussov refere-se à grande quantidade de pratos que eram produzidos para um único jantar. Os banquetes russos eram famosos pelo alto número de pratos e não tanto pelo refinamento. Não era incomum haver mais de 200 pratos diferentes, que misturavam sopas, tortas, carnes, saladas, queijos, todos de variados tipos. Após comerem o bastante, os convidados iam para outro recinto onde estavam as sobremesas. (Figes, 2002, cit., p.164)

- Alto posto da corte.

- Posto passado de pai para filho. Uma chave era a insígnia para o posto. Da Rússia anterior à Revolução. Diz-se de chave de ouro, para registro na Corte, com laço de fita azul, que se carrega no bolso de trás da farda/uniforme, e aparece como insígnia para o cargo de camareiro - símbolo de livre acesso aos aposentos do Czar.

- O excerto é muito famoso na língua russa. 
- Do alemão. Espécie de carruagem luxuosa levada por vários pares de cavalos, um atrás do outro. Símbolo de máxima distinção na nobreza.

- Soberana Catarina - Catarina II (1729-1796).

- Jogo ancestral ao bridge, muito difundido no século XVIII e, em especial, no século XIX. Disputava-se com um baralho de 52 cartas, que é dividido equitativamente por quatro jogadores em duas parcerias, valendo um ponto cada vaza acima das seis que compõem o book.

- Ditado famoso na língua russa.

- Tchátski representa toda a juventude que foi para a Europa e retornou com diversas críticas em relação à situação sustentada na sociedade: "(...)Eles eram capazes de comparar tudo que haviam visto no estrangeiro com o que confrontavam, a cada passo, em casa: a servidão da maioria dos Russos, o tratamento cruel dos subordinados pelos superiores, todo tipo de abusos do governo, e a tirania geral. Tudo isso agitava a intelligentsia russa e provocava um sentimento patriótico". (MAZOUR, Anatole G. The First Russian Revolution, 1825: The Decembrist movement. California: University of California Press, 1964, p.55, trecho em tradução nossa)

- Do italiano, cabornare (1816) - 'carvoeiro', 'carbonário' - há quem explique o termo pela linguagem. Os membros da sociedade secreta teriam sido assim designados em função de usarem em seu linguajar palavras técnicas próprias dos carvoeiros. O vocábulo provém do fato de os membros da sociedade secreta carbonária se reunirem (fins do século XVIII) em cabanas de carvoeiros em Nápoles. O carbonarismo 
é derivado da franco-maçonaria e surgiu na Itália, em princípio do século XIX. Os dezembristas foram atraídos pela maçonaria. Ela não se fixava, principalmente, nas questões políticas, mas sim, nas morais. Um dos líderes ativos é Nóvikov. (Mazour, 1964, cit., pp 4753; WALICKI, Andrzej. A History of Russian Thought: From the Enlightment to Marxism. California: Stanford University Press, 1979, pp. 14 -39)

- Literalmente, do russo, "Alma se liberta na confissão".

- Referência à Sodoma, da narrativa Sodoma e Gomorra, da Bíblia. Em russo, a palavra sodoma está aliada ao conceito de "barulho", "desordem", "rebuliço".

- Skalozúb - Скалить + Зуб (Skalit' + Zub) - mostrar/arreganhar os dentes - geralmente associado a animais que mostram os dentes como forma de ameaça ao oponente. Na personalidade de Skalozúb, é uma contradição, pois apesar de seu porte, ele é um homem tolo. Assim, a palavra Skalozúb passou a ser associada a quem se considera uma grande pessoa, mas não o é.

- Dezoito anos era a média idade para as mulheres se casarem, na Rússia. Sendo assim, mesmo que Fámussov tenha dito a Tchátski que Sófia, sua filha, não está na idade de casar, ela, aos dezessete anos, enquadra-se no grupo mencionado. Subentende-se que, ao referir-se à possível esposa do General, Fámussov espera que Skalozúb compreenda a menção indireta de que ele mesmo possui uma filha em idade para casar. E ele é o noivo perfeito.

- 0 pão tem um significado religioso para os russos e sua simples referência remete-se a riqueza e hospitalidade: "O pão era frequentemente oferecido como um presente, propriamente nas 
costumeiras oferendas de pão e sal aos visitantes". (Figes, 2002, cit.,p. 165, trecho em tradução nossa)

- "Jamais os poetas, que haviam descrito o incêndio lendário de Troia puderam evocar, em sua imaginação, qualquer coisa de exatamente comparável ao incêndio de Moscou. Um vento desencadeado, causado pelo próprio incêndio, levantou turbilhões de fogos: poderíamos dizer que era um oceano furioso e flamante. As ondas das chamas surtiam de todos os lados, montavam-se com uma rapidez inacreditável pelo céu incandescente e recaiam, não menos precipitadamente, naquele mar de fogo. Esse foi o espetáculo mais grandioso, mais estupefator, mas também o mais terrível que já me foi possível ver". (NAZAREVSKI, V. V. Histoire de Moscou: depuis les origins jusqu'a nos jours. traduit du russe par Serge Kaznakoff. Paris: Payot, 1932. pp 232, trecho em tradução nossa)

- "Toda família nobre sentiu, instintivamente, a necessidade de reconstruir sua antiga casa, então Moscou foi reconstruída com uma velocidade fantástica. Tolstói comparou o que aconteceu com a forma como as formigas que retornam ao seu monte em ruínas, jogando pedaços de lixo, ovos e corpos, e reconstruindo sua antiga vida com uma energia renovada. Isso mostrou que havia "algo indestrutível" que, embora intangível, era a "real força da colônia".(Figes, 2002, cit., p. 154, trecho em tradução nossa)

- Após o incêndio de Moscou, houve a restauração e criação de mais monumentos, edifícios suntuosos, e largas avenidas "Após 1812, o centro da cidade foi finalmente reconstruído, no estilo europeu. 0 fogo abriu espaço para os princípios expansivos do Classicismo (...) A Praça Vermelha foi aberta mediante a remoção de velhas tendas de comércio que the davam a sensação de um mercado fechado do que um espaço público aberto. Três novas avenidas foram construídas em 
um formato de leque da praça.(...) A primeira das várias edificações foi a Praça do Teatro, com o Teatro Bolshói em seu centro, foi completada em $1824(\ldots)^{\prime \prime}$. (Figes, 2002, cit., p. 154, trecho em tradução nossa)

- Antigamente, na Rússia, era costume fazer um nó em um pequeno lenço para lembrar-se de algo.

- Frase muito famosa no linguajar russo. Pergunta retórica que remete a Bíblia: "Não queirais julgar, para que não sejais julgados. Pois com o juízo com que julgardes, sereis julgados: e com a medida com que medirdes, vos medirão também a vós." (7: 14 - Evangelho de S. Mateus)

- Otchakov aparece também em Evguiéni Oniéguin: "(...) Nos braços seus me viu com ânsia,/Quando, no tempo meu de infância,/Com a cruz de Otchakov eu brincava!" (Evguiéni Oniéguin, Capítulo II, XXXVII, cit., p.119)

- Otchakov - cidade conquistada numa guerra entre a Rússia e o Império Otomano, na época de Catarina. A Rússia ganhou todas as terras próximas do mar Negro, inclusive a Crimeia.

- Após 1812, os nobres russos passaram a valorizar mais a infância e as crianças eram preparadas para serem pequenos adultos. As meninas aprendiam a dançar e frequentavam bailes organizados por mestres especializados. Os meninos, se militares, eram levados à Guarda e usavam uniformes antes mesmo de poderem carregar uma espada. Se direcionados ao mundo civil, eles eram colocados em escolas de formação aos oito anos de idade e vestiam um uniforme civil. (Figes, 2002, cit., p. 120) 
- Nestor - primeiro historiador russo, do final do século XII. Escreveu a primeira história da Rússia.

- A nobreza russa era muito apegada à caça. Eles prezavam as boas raças de cães como forma de distinção entre si. Eis o porquê da referência ao galgo - um cão de corpo alongado, extremamente veloz.

- Tornou-se costume dos nobres exporem seus servos em festividades e encenações. O tio de Aleksandr Griboiédov, Aleksei, tinha sua própria trupe de atores e atrizes servos.

\section{ATO III}

- Versos remetem aos da Condessa Lelieva, no Ato III, da peça Lição para Coquetes: Я здесь его дождусь, в любви его ко мне признания добьюсь."

-Eclesiastes - "Tudo é vaidade".

- "A aristocracia de Moscou (...) passava o Verão no campo e vinha para Moscou em Outubro, para a estação de inverno de bailes e banquetes, retornando para suas propriedades no campo tão logo as estradas estavam transitáveis, após o degelo". (Figes, 2002, cit., p. 154, trecho em tradução nossa)

- Comandante de guarnição de Moscou. Seu chefe era o general/governador.

- Na Rússia Czarista antes de 1917. 
- Os pais tinham que se humilhar frente às pessoas para garantir 0 futuro das filhas.

- Grau baixo na hierarquia da corte. Mais ou menos como capitão.

-Provém de Господин H. (Gospodin N.) - Senhor N.

-Provém de Господин Д. (Gospodin D.) - Senhor D.

- Nessas sentenças, a Condessa-avô imita sotaque francês-alemão.

- A grande maioria dos dezembristas possui uma origem na maçonaria: "Por volta de 1822, ou seja, na véspera da completa abolição das organizações maçônicas, a maioria dos Dezembristas havia deixado suas lojas, um movimento que era apenas natural desde que a Maçonaria provou ser um campo muito estreito aos jovens politicamente ambiciosos que, mais cedo ou mais tarde, sentiram a necessidade de organizar sociedades próprias. (...) 0 princípio geral da organização secreta, a natureza do juramento, dos ritos de iniciação, mesmo dos símbolos, e, como a sociedade sulista mencionada anteriormente, mesmo o nome, fora copiado dos Maçons". (Mazour, 1964, cit., p. 52, trecho em tradução nossa)

- Voltaire era uma grande referência intelectual na época, assim como as peças escritas por ele - "A maioria dos Dezembristas eram alunos dos Enciclopedistas, e eram profundamente influenciados pelo movimento revolucionário na França e em outros países, e eles nutriam as ideias de seus predecessores Krétchetov, Radíschev, ou Pnin, liberais prévios que sofreram por seus ideais". (Mazour, 1964, cit., p. 54, trecho em tradução nossa) 
- "Para Sumarókov e para Trediakóvski, Voltaire não era o livrepensador e o libertário que gerações subsequentes vieram a admirar, mas o dramaturgo supremo da época, o principal mantenedor da chama da pureza clássica, já ameaçado, de alguma forma, por processos inevitáveis de evolução literária". (Karlinsky, 1985, p.66, trecho em tradução nossa)

- Uma das primeiras sociedades secretas, na Rússia, surgiu em 1816 e foi substituída por outra, de maior envergadura, a Soiuz Blagodienstvia ou União da Prosperidade, cujos estatutos foram copiados do Tugendbund alemão. Os componentes são, em sua maioria, oficiais da guarda. Eles eram instruídos pelo sistema pedagógico de Lancaster. "(...) e se distinguiam de seus colegas por sua humanidade em relação aos seus subordinados. Eles pretendiam estender o campo de suas ações liberais. Eles sonhavam agir legalmente ao elevar o nível intelectual do povo pela instrução, com a esperança de propagar ao público o desejo de liberdade política e de reformas sociais". (Nazarevski, 1932, cit., trecho em tradução nossa). É a partir dessa sociedade que se formam as duas maiores sociedades secretas russas. Uma delas, organizada pelo príncipe Trubetskoi, dará origem ao movimento dezembrista: a Sociedade do Norte, em São Petersburgo.

- Segundo Karlinsky: "A sátira da desdenha aristocrática pelas ciências, educação, e instituições de elevado aprendizado, no final do Ato III, eram um eco atrasado do tema disseminado e popular do século XVIII, familiar na Literatura Russa desde as sátiras de Antiokh Kantemir". (Karlinsky, 1985, cit., p. 300, trecho em tradução nossa)

- Título do ensaio de Gontcharov sobre a peça. 
- Griboiédov era um francófobo. Por possível influência de seu professor de universidade, Johann Gottlieb Bühle, Griboiédov criou um profundo ódio às coisas francesas. (Kelly, 2002, cit., p.12)

-O escritor Mikhail Saltykov-Schedrin diz: "Na Rússia, nós apenas existíamos no sentido factual, ou como era dito na época, nós tínhamos um "modo de vida". Nós íamos ao trabalho, nós escrevíamos cartas a nossos parentes, nós jantávamos em restaurantes, nós conversávamos uns com os outros e por aí vai. Mas, espiritualmente, nós éramos todos habitantes da França". (Figes, 2002, cit., p.55, trecho em tradução nossa)

- "A Guerra de 1812-14, que tomou um aspecto nacional amplo, e especialmente o incêndio de Moscou, estimularam muito o sentimento chauvinista." (Mazour, 1964, cit., p.29, trecho em tradução nossa)

\section{ATO IV}

- Paralelo a Molière, no Ato I, conversa entre Filinto e Alceste: "E às vezes se me dá a irresistível gana/De num deserto alhear-me a toda a espécie humana." (MOLIÈRE. O misantropo/O tartufo. tradução de Jenny Klabin Segall. 2a edição. São Paulo: Martins Fontes, 2005, p. 140)

- Segundo Lawrence Kelly, um possível paralelo, na vida real, com a figura do príncipe Grigóri, é o conde Aleksandr Zavadóvski, amigo de Griboiédov, um membro iniciante da corte e o contraponto no duelo contra Cheremietiev. Recém-chegado da Inglaterra, Zavadóvski apaixonara-se tanto pelo país que passara a adquirir seus costumes e, sendo assim, a ser chamado de "o Inglês" (Kelly, 2002, cit.). 
- Segundo Karlinsky, esse excerto é testemunho da familiaridade de Griboiédov com o trabalho interno dos dezembristas: "Repietilov cita uma frase da ópera Didone Abbandonata, de Baldassare Galuppi, "Ah, non lasciarmi, no, no, no," que era usada pelos dezembristas como senha". (Karlinsky, 1985, cit.,p.295, trecho em tradução nossa)

- Região muito afastada de Moscou, cerca de 12000 km.

-Um sargento, posto entre oficial e soldado.

- Segundo Bestújev, Griboiedov atestava não estar interessado em mulheres, no período que viveu em São Petersburgo - "Ele reivindicava (...), citando a observação de Byron de que as mulgeres eram apenas crianças: "Dê-Ihes um doce de ameixa ou um espelho e elas estarão perfeitamente felizes".(Kelly, 2002, cit., p. 42, trecho em tradução nossa)

-Домовой (Domovói) - duendes, seres do outro mundo que, na crença folclórica russa, habitavam as casas.

- Paralelo à Molière, no primeiro ato, conversa entre Alceste e Filinto: "Eu não estou brincando/E não quero poupar ninguém em tal desmando./Do que ao redor se vê, meus olhos se ressentem,/Nada há com que minha ira e meu fel não se esquentem/Entro num negro humor, num profundo despeito,/Vendo os homens viver entre si desse jeito;/ Na corte, e fora, é só covarde adulação,/Injustiça e perfídia, interesse e traição:/Eu não me aguento mais e a fúria em que me dano/Me leva a provocar todo o gênero humano." (Molière, 2005, cit., p. 138)

- Paralelo à Molière, na última frase de Alceste, em O misantropo: "Do abismo em que o mal reina eu fujo, e sobre a terra/Busco um 
sítio remoto, em que à luz da verdade,/De ser homem de bem se tenha a liberdade." (Molière, 2005, cit., p.138). 


\section{PARTE II}

Caminho Crítico 


\section{Os pavimentos}

Os embriões mais vivos, para que obras como Горе от ума (Gorie ot uma) nascessem, instalam-se no início do período neoclássico russo que, ao final, culminaria em uma variada gama de experimentos misturando as regras clássicas com rupturas drásticas e inovadoras. Passada a grande época de Molière, no século XVII, uma série de novas formas de comédia surgiram na França. Podemos lembrar, em primeiro lugar, da comédie larmoyante, cujos principais nomes são Nivelle de La Chaussé (L'école des mères), Destouches, entre outros; em segundo lugar, o drame sérieux, principalmente difundido por Denis Diderot e seguido por Sedaine e Gresset; e, em terceiro lugar, o vaudeville, uma forma híbrida em cujas bases é possível identificar características da comédie larmoyante e da óperacômica - sendo os últimos gêneros bastante explorados pelos antecessores de Aleksandr Griboiédov. ${ }^{28}$

Aurora Bernardini, em um artigo denominado "Púchkin e o Começo da literatura russa", afirma que "não é de estranhar que alguns entre os primeiros poetas a escrever em russo, como Kantemir e Derjávin, o tenham feito nos moldes da versificação francesa clássica"29. Sendo assim, para trilharmos o caminho

\footnotetext{
${ }^{28}$ BROWN, William E. A History of Russian Literature of the Romantic Period: Volume One. Michigan: Ardis Publishers, 1986. p.61.

${ }^{29}$ BERNARDINI, Aurora. "Púchkin e o começo da literatura russa" in. Caderno de Literatura e Cultura Russa, n.1, São Paulo: Ateliê Editorial, 2004, p. 33.
} 
neoclássico russo ${ }^{30}$, devemos nos ater nas formas com que o modelo francês pôde alcançar a Rússia e sofrer as transposições, adaptações, criações e transformações, que ganhariam cor diversa em seu novo local. Para tal, a nossa estrada começa junto aos rudimentos da formação da língua literária russa.

No início do século XVIII, quaisquer tentativas de tradução da obra de Molière, por exemplo, surgiam como tarefas inatingíveis, haja vista a grande carência de vocabulários e estruturas, no russo eclesiástico, que pudessem combinar-se com as nuances provenientes de temáticas tão distantes das religiosas.

Para Belínski (1845),

A Literatura Russa começa com Lomonóssov. Ele foi, de verdade, o fundador da Literatura Russa. Como um homem de gênio, ele deu a ela uma forma e uma direção, que ela manteve por muito tempo. O que significa essa forma e essa direção é outro assunto, mas o fato é que dar forma e direção a uma literatura inteira poderia ser feito apenas por um homem extraordinário, mas, ainda que haja um acordo geral acerca de que a Literatura Russa inicia-se com Lomonóssov, todos começam a contá-la a partir de Kantemir ${ }^{31}$.

\footnotetext{
${ }^{30} \mathrm{~A}$ expressão "Neoclassicismo Russo" não figura nos estudos da Rússia propriamente dita. Na Rússia, o equivalente é: Classicismo Russo. Referimo-nos a essa época da maneira utilizada em estudos ocidentais, pois a formação literária pode ser estudada em seus períodos. Como o período do Classicismo Russo é simultâneo a outros movimentos europeus, por exemplo, escolhemos por denominá-lo como o fazem alguns teóricos ocidentais: Neoclassicismo Russo.

31 BELINSKI, V.G. Kantemir. Sobránie Sotchiniêni v triekh tomakh. T. II. M., 1948, trecho em tradução nossa, http://az.lib.ru/b/belinskij_w_g/text_1220.shtml, acesso em 14/05/2010).
} 
Os primeiros e substanciais esforços para a formação de uma língua literária tiveram início ainda no reino da imperatriz Anna (1730-1740), na figura do príncipe Antiokh Dmítrievitch Kantemir ${ }^{32}$. Mediante os ditames da poética de Nicolas Boileau (1635-1711) $)^{33}$, Kantemir escreveu diversas sátiras, sem qualquer valor literário, mas dotadas de grande ousadia ${ }^{34}$. As sátiras de Kantemir são uma imitação e, em sua maior parte, tradução, adaptação de uma série de sátiras de Horácio, Boileau e, frequentemente, de Juvenal, mas, não obstante, elas são um trabalho altamente original, tanto que Kantemir pôde aplicá-las à vida cotidiana e às necessidades da sociedade russa. Ele ataca o fanatismo da ignorância, os preconceitos da sociedade contemporânea russa ${ }^{35}$.

Ele, assim, para Belínski não propriamente "começa a história da literatura russa; ele encerra um período da literatura russa". Apesar da linguagem datada com que escrevia, apesar da pobreza do elemento poético em sua poesia, suas sátiras ergueram um pequeno, modesto, mas ainda assim, imortal monumento da literatura russa.

\footnotetext{
${ }^{32}$ Antiokh Dmítrievitch Kantemir (1708-1744) - poeta, tradutor, prosador e diplomata. Segundo o Índice de Notas e Referências, Kantemir, além de estabelecer as bases ao Classicismo Russo, escreveu um dos primeiros tratados de métrica e versificação para a língua russa.

${ }^{33}$ Também chamado de Boileau-Despréaux. Escritor de sátiras e epístolas, ele publicou, em 1674, a L'art Poétique (em forma de poema), um guia para toda a técnica da poesia francesa. - "Ele propõe, no seu poema didático, que trata de todas as formas literárias, o resumo das regras e do espírito de uma literatura clássica codificada e estritamente dividida em gêneros." (org. Boileau, 2004, p.129130).

${ }^{34}$ Segundo Karlinsky, essa ousadia deve-se, principalmente, "porque o autor voltouse a exemplos ocidentais em detrimento das formas há muito obsoletas no Ocidente, tais como as peças jesuíticas e os contos de cavalaria."(in. KARLINSKY, Simon. Russian drama: from its beginning to the age of Púchkin. Califórnia: University of Carolina Press, 1985.p. 61).

${ }^{35}$ Belínski, 1948, cit., trecho em tradução nossa.
} 
Ele foi o primeiro na Rússia a trazer a poesia à vida - enquanto que Lomonóssov fez com que ela sobrevivesse por muito tempo. ${ }^{36}$

Em 1735, o escritor Vassili Trediakóvski (1703-1769) sempre preocupado com as possibilidades que a língua russa poderia ofertar ao texto escrito -, iniciou a reforma da versificação russa com - Новый и краткий способ к сложению российских стихов с определениями до сего надлежащих званий (Novyi i kratkii spossob k slojeniu rossiiskikh stikhov s opredielieniami do sievo nadliejaschikh zvanii, Novo e Breve Manual para a Elaboração dos Versos Russos, 1735), sendo responsável, também, por uma reforma ortográfica, em 1748 , do russo, segundo fundamentos fonéticos ${ }^{37}$. Ele introduziu a noção de pés ${ }^{38}$ métricos, mediante a produção de versos trocaicos ${ }^{39}$. Essa inovação trouxe o sistema silábico para a língua russa. Passados alguns anos, Mikhail Lomonóssov $(1711-1765)^{40}$, importante pensador e historiador russo, e o verdadeiro pai da literatura russa, completou a reforma métrica e prosódica ao enviar para a Academia

\footnotetext{
${ }^{36}$ Trechos em aspas: Belínski, 1948, cit., em tradução nossa.

37 Cf. sobre Trediakóvski: ANDRADE, Homero F. "Índice de Nomes e Referências" in. Caderno de Literatura e Cultura Russa, n.1, São Paulo: Ateliê Editorial, 2004, p.234.

${ }^{38}$ Segundo Aurora Bernardini (BERNARDINI, 2004), os pés usados na poesia russa são: "para os metros binários, o iambo (sílaba breve, sílaba longa) e o troqueu (sílaba longa, sílaba breve); para os metros ternários, o dátilo (uma sílaba longa, duas breves), o anapesto (duas sílabas breves e uma longa) e o anfibráquio (sílaba breve, sílaba longa e sílaba breve).

39 Versos compostos de troqueus. Do grego trokhaïkós, os troqueus consistem na conjunção de uma sílaba longa e uma sílaba breve. São comumente chamados de pé métricos greco-latinos. É o mesmo que coreu.

40 Mikhail Vassílievitch Lomonóssov (1711-65) foi uma figura de significativa importância no desenvolvimento da cultura russa. Ele era um cientista de renome, um importante gramático e um poeta de genuíno talento. (Karlinsky, 1985, cit., p.75) Entre suas peças, Тамира и Селим ( Tamira i Sielim, 1750); Демофонт (Diemofont, 1751).
} 
de Ciências na Rússia, sua Оды похвальные и оды духовные (Ody pokhvalnye $i$ ody dukhovnye, Odes de louvor e odes do espírito $)^{41}$. Lomonóssov foi o autor, o indivíduo na poesia, "o primeiro dos rebeldes $^{\prime \prime 2}$, e, sendo assim, aparece como a grande figura inaugural da palavra russa como arte. Segundo Aksákov, "ele fez o escopo das canções nacionais, não as destruindo, mas elevando a nação para introduzir a poesia em uma nova área (...) para dar a ela todo o conteúdo (...) Esse indivíduo, esse gênio era Lomonóssov"433.

Aurora Bernardini explica como Trediakóvski e Lomonóssov experimentaram o sistema sílabo-tônico, tão crucial à fundamentação da literatura russa em seus primórdios:

O sistema tem raízes na metrificação greco-latina clássica e também é usado na poesia alemã e inglesa. Uma vez que em russo o acento de intensidade desempenha um papel importante, como no inglês e no alemão, era natural que esse tipo de metrificação se firmasse na Rússia como sendo o mais apropriado para sua expressão poética ${ }^{44}$.

Esse trabalho de experimentação só encontrou sua grandeza

final nas mãos de Púchkin, que "consagrou esse novo modelo, levado adiante por seus sucessores até a época contemporânea,

${ }^{41} \mathrm{O}$ texto de Lomonóssov foi escrito em tetrâmetros iâmbicos, e era acompanhado de um tratado detalhado acerca das possibilidades do uso de metros binários e ternários, bem como rimas masculinas e femininas no verso russo.(op.cit, p.62). Sobre Lomonóssov, é importante saber que ele "introduziu a noção de enciclopedismo na Rússia e almejava criar os fundamentos de uma ciência e de uma literatura genuinamente russas, que se igualassem às suas congêneres do Ocidente" e foi "responsável por descobertas e elaboração de conceitos importantes, sobretudo nos campos da física, da química, da geologia", fundando a Universidade de Moscou e "escreveu a primeira gramática da língua russa (1755)" (Índice de Nomes e Referências, 2004, cit., p. 228).

${ }^{42}$ Cf. AKSAKOV, K. S. "Lomonóssov $v$ istorii russkoi litieratury i russkovo izyka". Litieraturnaia kritika. M.: Sovriemiênik, 1981, http://az.lib.ru/a/aksakow_k_s/text_0230.shtml, primeiro acesso em 14/05/2010). ${ }^{43}$ Aksakov, 1981, cit., trecho em tradução nossa.

${ }^{44}$ Bernardini, 2004, cit., p. 33. 
amalgamando a herança do passado (diferente da tradição inglesa e alemã)". Com Púchkin, o trabalho dos antecessores encontrou lugar final, em um universo poético inovador e incomum, tornando-se, assim, a verdadeira base clássica russa.

Para Belínski (1845), "se Kantemir e Trediakóvski não foram os fundadores da literatura russa, suas obras foram, de alguma maneira, o prefácio para sua base ${ }^{\prime 45}$. E, juntamente com Lomonóssov ${ }^{46}$ foram nomes que se assomaram a um outro, muito significativo na época, e que deram ao Teatro Russo um ponto de partida, mudando a forma com que deveria ser pensado. O outro? Aleksandr Sumarókov, o Racine ${ }^{47}$ da Rússia. Antes de escrever sua primeira obra dramática, Sumarókov já era considerado uma das figuras mais cruciais da poesia russa e, junto a Lomonóssov e Trediakóvski, pôde apresentar espetáculos russos, encorajados pela própria imperatriz Ielizavieta (o reino, 1741-62).

Sumarókov conseguiu sobressair-se tanto pela personalidade tirana, a que muitos de seus contemporâneos referem-se, quanto por sua associação a Racine, ou seja, a transposição de todas as paixões humanas refratadas na psicologia da personagem. Mas, mesmo formando um repertório de suma importância para o futuro do Teatro

\footnotetext{
${ }^{45}$ Belínski, 1948, cit., trecho em tradução nossa.

46 "Os esforços de Kantemir. Trediakóvski, Lomonóssov e Sumarokov trouxeram a linguagem literária russa a um ponto em que ela estava pronta para acomodar o drama neoclássico, recentemente popular na Rússia". (Karlinsky,1985, cit., p.64) Tanto Lomonóssov, Treadiakovski e Sumarokov consideravam-se, cada um, o precursor do Neoclassicismo na Rússia. O título, no entanto, para a posteridade, pertence à Sumarokov e a tragédia Хорев (Khoriev,1747).

47 Jean Racine (1639-1699) - dramaturgo francês de Andromaque, Athalie, Iphigénie, Phèdre.
} 
Russo, suas peças pouco conseguiram sobreviver ao século XIX e, por quase cem anos (de 1787 a 1893), não foram publicadas na Rússia ${ }^{48}$. Os modelos para os textos? Os franceses Corneille ${ }^{49}$, Racine e Philippe Quinault ${ }^{50}$, e, principalmente, Voltaire. Não o Voltaire enciclopedista, pai de muitos pensadores, cujas obras transcendem o crivo do tempo. Mas sim o Voltaire dramaturgo, escritor de Alzire, Brutus, La Henriade, Mahomet, Oedipe-roi, L'Orphelin de La Chine, Zaire. E isso porque, em suas peças, Voltaire conseguia manter a pureza das regras clássicas, com sua grandiloquência retórica ${ }^{51}$. A temática da tragédia ${ }^{52}$ neoclássica francesa, segundo Francis Fergusson, instalava-se na ação do herói em busca do triunfo da vontade ultrapassando 0 instinto. ${ }^{53} \mathrm{Na}$ transposição das obras francesas para a Rússia, em sua cada vez mais crescente linguagem literária, esses primeiros dramaturgos puderam antever que algo estava sendo preparado, em prol de uma linguagem mais rica e

\footnotetext{
${ }^{48}$ Karlinsky, 1985, cit., p. 72.

49 Pierre Corneille (1606-1684) - dramaturgo francês de Le Cid, Cinna, Le menteur.

50 Philippe Quinault (1635-1688) - libretista francês das óperas de Jean Baptiste Lully, ainda famoso no século XVIII.

${ }^{51}$ BROWN, William E. A history of russian literature of the Romantic Period:
} Volume One. Michigan: Ardis Publishers, 1986. p.31.

${ }^{52}$ Fazemos aqui um caminho semelhante ao de Belínski, em seu ensaio sobre Gorie ot uma. Antes de começar a falar da peça ele se propôs a compreender a poesia dramática e sua divisão em tragédia e comédia: "A tarefa que nós propomos neste artigo é descrever a divisão da poesia dramática em tragédia e comédia e, nestas bases, produzir uma avaliação crítica à célebre obra de Griboiédov." (Belínski, 1839, cit., trecho em tradução nossa).

53 Boileau, em sua arte poética, já anunciava os ditames da tragédia em ideia semelhante: "Que em todos os discursos a paixão comovente/Busque o coração, o perturbe e aquente./Se um belo movimento do agradável furor/Não nos encher sempre de um doce terror,/Nem excitar na alma a piedade encantadora (..)" (Boileau, Nicolas. "A emoção trágica". "Arte Poética" (org. Monique Borie, Martine de Rougemont, Jacques Scherer). In: Estética Teatral: textos de Platão a Brecht. tradução de Helena Barbas. Lisboa: Fundação Calouste Gulbenkian, 2004. Canto III-1, VV-1-26) 
adequada à representação da matéria do homem, suas vontades e instintos ${ }^{54}$. No entanto, o mundo pouco conhece, profundamente, esses textos iniciais e, por conter uma força cada vez mais datada, devido à evolução da língua, pertencem apenas ao século XVIII, e não à posteridade. Mas as cinco tragédias de Sumarókov, escritas entre 1747 e 1760 - ou seja, Хорев (Khoriev); Артистона (Artistona); Семира (Semira); Синав и Трувор (Sinav i Truvor); Гамлет (Hamlet) -, formam o repertório basal do Teatro Russo. ${ }^{55}$

A tragédia neoclássica ${ }^{56}$, subsequente ao período dos dramaturgos iniciais citados acima, prosseguiu pela segunda metade do século XVIII, ofertando mudanças na linguagem literária que abrissem o campo para a comédia neoclássica russa. Sumarókov, profícuo escritor que era, também se aventurou pelo universo cômico, escrevendo, ao todo, doze comédias e, como preceitos, lança a lei fundamental: a comédia deve conter uma zombaria que objetiva a correção moral. Seguem-no Mikhail Kheraskov ${ }^{57}$, Vladímir Lukin ${ }^{58}$ e

54 Sumarokov copiou a estrutura formal da tragédia francesa do século XVII e quase de maneira fotográfica. Mas falta a poesia, a profundidade humana e a sutileza psicológicas que podemos encontrar em Corneille e Racine. (KARLINSKY, Simon. Russian drama: from its beginning to the age of Púchkin. Califórnia: University of Carolina Press, 1985., p.69) Fosse de outra forma, talvez, as peças de Sumarokov conseguissem obter uma fortuna crítica de sua contribuição no teatro russo. Ao contrário, recebem apenas capítulos concernentes apenas ao século XVIII. Até Lomonóssov, em uma crítica aberta, disse que tudo o que havia de bom em Sumarokov provinha dos franceses. De maneira irônica, Fonvizin, direto de Paris, afirmou que Sumarokov era um dos escritores franceses mais pedantes e absurdos que ele conhecera.

55 ibidem, p. 67

${ }^{56} \mathrm{~A}$ tragédia russa continuou a ser escrita em estrofes de hexâmetros iâmbicos até o período da obra Boris Godunov, de Aleksandr Púchkin, quando Shakespeare substituiu Corneille e os pentâmetros iâmbicos sem rima passaram a ser a norma. (ibidem, p.76)

57 Mikhail Kheraskov (1733-1807) - dramaturgo russo do século XVIII. Escreveu, entre outras, Ненавистник (Biezbojnik, 1770); Венецианская 
Denis Fonvízin ${ }^{59}$. Muitas das obras desses dramaturgos encontram origem na comédie larmoyante francesa, já mencionada acima, e a primeira obra a ser relembrada é Безбожник (Biezbojnik, O ateu, 1761), de Kheraskov.

Dos dramaturgos precursores na comédia russa, vale ressaltar, principalmente, Denis Fonvízin e sua comédia, Недоролсь (Hiedorols', O parvo, 1779). Apesar da trama convencional, e por vezes tola, a peça apresenta personagens de forte envergadura, construídos de maneira realista ${ }^{60}$, ou seja, de modo a tentar transpor os verdadeiros aspectos da realidade russa. Trata-se de uma sátira mordaz, que confronta os universos dos provincianos e ignorantes com os dos civilizados portadores do Iluminismo. ${ }^{61}$

No entanto, apesar de toda a visceralidade, em relação à época, com que a peça é escrita, ela ainda é, genuinamente, um produto do século XVIII, ou seja, é uma comédia neoclássica. A regra das unidades é respeitada de maneira rigorosa.

монахиня (Venietsianskaia monakhinia, 1758); Освобожденная Москва
(Osvobojdienaia Moskva, 1798).
58 Vladímir Lukin (1737-1794)-dramaturgo russo do século XVIII
59 Denis Fonvízin (1745 - 1792) - dramaturgo russo do século XVIII. Sua comédia,
Недоролсь (Niedorols', O parvo), tornou-se a peça mais importante de todo o
século XVIII, podendo ser encontrada em versões em inglês, francês e italiano.
Escreveu também Бригадир (Brigadir, Brigadeiro, 1768); Корион (Korion, 1764).
60 BROWN, William E. A history of russian literature of the Romantic Period: Volume One. Michigan: Ardis Publishers, 1986, p. 60.

61"A colisão entre a classe provinciana rude e ignorante (os Prostakovs e Skotinin) e os porta-vozes civilizados do Esclarecimento (Starodum, Pravdin e Milon) é um jogo justo, porque embora o bom caráter tenha a verdade e a justiça a seu lado, os maus, com sua linguagem colorida e energia dinâmica (muitas vezes perdidas nas traduções) são muito mais arrebatadoras dramaticamente". (KARLINSKY, Simon. Russian drama: from its beginning to the age of Púchkin. Califórnia: University of Carolina Press, 1985, trecho em tradução nossa, p.162) 
E que significam essas unidades? Provenientes dos preceitos da Arte Poética de Aristóteles e de Corneille, a regra das três unidades, instalou-se como lei máxima no Neoclassicismo. Mairet, dramaturgo francês, em um prefácio à sua tragicomédia pastoral Silvanira, apresenta-nos uma disposição da comédia em partes ${ }^{62}$. Dramaturgo em período acalorado e de fortes discussões acerca das regras para o teatro, ele foi o primeiro a afirmar a necessidade de respeitarem-se as três unidades, em prol da satisfação final do público. Na comédia, faz questão, assim, de classificar cada parte, às quais ele denomina como: prólogo, prótese, epítase e catástrofe:

O prólogo é uma espécie de prefácio no qual é permitido, além do argumento do assunto, dizer qualquer coisa a favor do poeta, da própria fábula, ou do autor.

Prótese é o primeiro ato da fábula, no qual uma parte do argumento é explicada, e a outra não se diz, a fim de reter a atenção dos auditores.

A epístase é a parte mais turbulenta da fábula, em que se vê aparecerem todas as dificuldades e as intrigas que se desenlaçam no fim, e que propriamente se pode chamar de o nó da peça.

A catástrofe é aquela que muda todas as coisas em alegria, e que presta o esclarecimento de todos os acidentes que aconteceram em cena. ${ }^{63}$

Essa estrutura, apresentada por Mairet, será encontrada, frequentemente, nas obras cômicas do Neoclassicismo Russo. Por vezes sem o prólogo, mas contendo, de maneira religiosa, as

62 Jean de Mairet (1604-1686) - teve curta carreira como dramaturgo, entre 1625 e 1640.

63 Mairet, Jean. "Os géneros do teatro". "Prefácio de Silvanira". (org. Monique Borie, Martine de Rougemont, Jacques Scherer). In: Estética Teatral: textos de Platão a Brecht. tradução de Helena Barbas. Lisboa: Fundação Calouste Gulbenkian, 2004. p. 89 
sequências da prótese, epítase e catástrofe. Essas partes, é claro, provém da estrutura maior, que consiste na junção das três unidades.

Há, em primeiro lugar, a unidade da ação; segundo ela, uma peça deve possuir uma ação principal, com algumas ou nenhuma trama secundária. Para Corneille, na comédia, a unidade da ação consiste "na unidade de intriga e obstáculo aos objetivos dos atores principais". Já na tragédia, o perigo ao qual sucumbe o herói deverá ser o que irá salvá-lo. Sendo assim,

[...] não deve haver senão uma ação completa que deixe o espírito do auditor na calma, mas ela só se pode tornar assim por intermédio de outras várias $\mathrm{e}$ imperfeitas, que lhe servem de encaminhamento e mantêm esse auditor numa agradável expectativa. ${ }^{64}$

Em segundo, há a unidade de lugar, ou seja, uma peça deve fixar-se em um só espaço físico; não deve tentar comprimir o espaço, nem mesmo representar, no palco, mais de um lugar. Segundo Corneille, "é preciso procurar essa unidade exata tanto quanto seja possível". Mas ele acredita que essa fixação, em um único local, deve ser bem idealizada, pois o que é apresentado em um teatro, em um quarto ou uma sala, não pode parecer uma decisão desastrada, pois é necessário "encontrar um qualquer alargamento para o local, como para o tempo." ${ }^{65}$

${ }^{64}$ Corneille, Pierre. "Unidade de acção". "Discursos" (org. Monique Borie, Martine de Rougemont, Jacques Scherer). In: Estética Teatral: textos de Platão a Brecht. tradução de Helena Barbas. Lisboa: Fundação Calouste Gulbenkian, 2004. p.114.

${ }^{65}$ Ibidem, p. 114 
E, enfim, em terceiro lugar, a unidade de tempo; segundo ela, a peça deve ocorrer em, no máximo, vinte e quatro horas. A compreensão acerca dessa unidade surgiu na poética de Aristóteles, onde ele observa que as tragédias, desde Ésquilo, conformam a ação em um único dia.

Voltaire, um dos grandes modelos para os dramaturgos russos, aferrava-se fortemente na regra das unidades. Em seu Discours sur la tragédie, ele afirma que "surgiria fraqueza e esterilidade se se estendesse uma ação para além do espaço de tempo e do lugar convenientes". Nada pode ser arbitrário no que tange ao teatro, pensa Voltaire, portanto:

Perguntai a quem tenha inserido numa peça demasiados acontecimentos os motivos desse erro: se está de boa fé, dir-vos-á que não tinha gênio suficiente para preencher a sua peça com um único fato; e se ele usa dois dias e duas cidades para a sua ação, acreditai que é porque não teria a habilidade de a encerrar no espaço de três horas e no recinto de um palácio, como o exige a verossimilhança. Acontece o contrário com aquele que ousaria apresentar um espetáculo horrível sobre o teatro: não chocaria a verossimilhança; e essa ousadia, longe de sugerir qualquer fraqueza por parte do autor, exigiria, pelo contrário, um grande gênio para, pelos seus versos, dar uma grandeza verdadeira a uma ação que, sem um estilo sublime, seria apenas atroz e repugnante. ${ }^{66}$

Sobre os neoclássicos, os quais muitos Belínski chamou de pseudoclássicos - denunciando assim o quanto determinadas obras,

66 Voltaire. "A mistura dos géneros". "Obras completas". (org. Monique Borie, Martine de Rougemont, Jacques Scherer). In: Estética Teatral: textos de Platão a Brecht. tradução de Helena Barbas. Lisboa: Fundação Calouste Gulbenkian, 2004. p.148. 
aferradas nas regras postuladas pelo período, seriam invalidadas no século XIX -, em seu ensaio a Gorie ot uma, reservamos um trecho muito interessante:

O antipoético Voltaire deu seu parecer despojado sobre Shakespeare. Sobretudo, nessa posição, para os clássicos, pior que qualquer desgraça são os autores que não se debruçam em suas palavras de composição: poema, tragédia, drama, comédia, vaudeville, ode, écloga, elegia e etc. Para nós, é simplesmente um assassinato! Aqui os clássicos são muito parecidos com os naturalistas: descoberta uma nova matéria do reino animal, vegetal ou mineral, o naturalista, antes de tudo, cuida do gênero e do aspecto, e se não obtém informação de um jeito ou de outro, então se empenha em conduzir seu achado para qualquer gênero conhecido, na qualidade de aspecto do recém-descoberto. Mas eis onde há uma diferença terrível entre os clássicos e naturalistas: se o gênero não se encontra em um tema recémdescoberto, e ele próprio não se encontra na cadeia de sistemas como gênero, então, o naturalista, apesar de tudo, não o exclui da cadeia de criações divinas, mas cuidadosamente, descrevendo-o em seus sinais, espera que, posteriormente, encontre-se para ele um lugar; já o clássico, não ponderando tanto, anuncia a obra artística como um absurdo, somente porque ela não se parece com nenhum gênero de arte conhecido. ${ }^{67}$

No entanto, apesar da rudeza dos pensamentos e direcionamentos aos neoclássicos, Belínski acredita numa junção de todas as válidas características tanto dos clássicos quanto dos românticos: "O clássico romântico é o representante de uma conciliação eclética do Classicismo com o Romantismo, no qual algo do Classicismo se mantém e algo é tomado do Romantismo." ${ }^{68}$

\footnotetext{
${ }^{67}$ Belínski, 1839, cit., trecho em tradução nossa.

${ }^{68}$ Nessa classificação, Belínski decreta: "Nossa mais nova arte, iniciada por Shakespeare e Cervantes, não é nem clássica porque "nós não somos gregos ou romanos" e nem romântica, porque não somos cavaleiros e nem trovadores
} 
As peças no Neoclassicismo Russo, nessa primeira fase, seguem religiosamente a regra das três unidades e, como falamos acima, assim também o faz Fonvízin em seu Недоролсь (Niedorols', O parvo). A ação inicia-se na manhã de um dia e termina na madrugada do dia seguinte. Todas as ações ocorrem em um único lugar, e a trama principal é única. Trata-se da história de uma mulher dominadora, a Sra. Prostakova, que faz de tudo para casar Sófia, a vizinha herdeira, com o seu irmão, Skotinin. Há algumas peripécias até que Sófia escapa das mãos dos Prostakovs, e casa-se com Milon, seu amor. Todas as intenções iniciais são amarradas ao final, e o objetivo se consuma: Sófia é recompensada pelo amor e a Sra. Prostakov é punida pelo ódio do filho.

Segundo Karlinsky, apesar da força moralizante da trama, até a época de sua estreia, nenhuma outra peça causara tantas imitações, sequências, adaptações. Nas três décadas seguintes, tendo as personagens de Недоролсь se tornado lendas no imaginário literário, surgiram comédias, óperas-cômicas, balés, nas quais Skotinin, Milon, entre outros, apareciam nos papéis secundários ou principais. $^{69}$

Para Belínski, a comédia russa começa muito antes de Fonvízin, mas começa apenas com Fonvízin ${ }^{70}$. Para o crítico russo,

medievais. Como então chamá-los? De modernos." (Belínski, 1839, cit., trecho em tradução nossa).

${ }^{69}$ Karlinsky, 1985, cit., p. 171.

70 Para Belínski (1845): "Em geral, para mim, Kantemir e Fonvízin, especialmente o último, são os mais interessantes escritores dos primeiros períodos de nossa literatura: (...) eles falam da realidade viva, que existe historicamente, da moral da 
"Недоросль" (Niedorols', O Parvo) и "Бригадир" (Brigadir, O

Brigadeiro) fizeram um alvoroço terrível quando apareceram e isso permanecerá para sempre na história da literatura russa, se não como arte, mas como um dos fenômenos mais destacáveis. Ele assegura que,

de fato, essas duas comédias são o produto da mente de um homem talentoso, perspicaz, forte, mas elas são obras satíricas sobre a sociedade contemporânea e, sendo assim, não são obras de arte, e sendo assim, não são comédias. Nenhuma delas representa o mundo todo encerrado em si mesmo que surge de uma concepção criativa, mas uma caricatura da estupidez e da ignorância, ou seja, elas não possuem a ideia básica do sentido filosófico da palavra; há intento, propósito e objetivo por fora dela, mas não dentro de seu universo. Sendo assim, elas estão divididas em duas partes: a dos tolos e dos sábios. Os tolos são muito bons, engraçados e espertos - o Raisonneur é chato. A trama, a intriga e o desfecho - o lugar é o mesmo, a forma antiga e dilapidada, tal como nas comédias de Molière. Em suma, "Недоросль" (Niedorols', O parvo) и "Бригадир" (Brigadir, O Brigadeiro) são excelentes, embora não sem uma grande desvantagem no campo das obras da literatura, posto que não são obras de arte $^{71}$.

Para Gontcharov, "a chamada comédia imortal Недоросль

(Niedorols') permaneceu vívida por quase metade de um século: é um grande produto da palavra. Mas, agora, não há nenhum traço de Недоросль no universo da vida, da comédia, tendo, assim, terminado sua tarefa."

Das peças dos escritores citados acima, Недоролсь (Niedorols') é a única que permaneceu e alcançou os dias de hoje. Em se tratando de comédia, o Teatro Russo só veria novas grandezas - superiores,

sociedade, que é tão incomum em nossa sociedade, mas que foi seu próprio avô." (Belínski, 1948, cit., trecho em tradução nossa)

${ }^{71}$ Belínski, 1839, cit., trecho em tradução nossa. 
em muitos aspectos, a Fonvízin - quando Chakhovskói, Khmielnitski e, acima de todos, Griboiédov, escrevessem suas obras-primas. Mas, até lá, seu caminho ia se pavimentando em bases trabalhadas por outros escritores, menores em importância literária, mas fundamentais em sua história. Adentraremos, em primeiro momento, nos universos da ópera-cômica (proveniente do modelo francês, principalmente das obras de Charles Simon Favart ${ }^{72}$, Jean-Jacques Rousseau $^{73}$ e Michel-Jean Sedaine ${ }^{74}$ ) e, em seguida, da comédia em versos.

O essencial a ser dito acerca da ópera-cômica é que, em suas bases, encontra-se um afrouxamento da regra das três unidades. Até o final do século XVIII, mais de cento e cinquenta obras desse gênero haviam sido criadas e encenadas. Gênero muito popular na época, ela consistia em uma breve peça, contendo um ou dois atos, pontilhada de canções e alguns coros. Nomes significativos para esse extrato são: Mikhail Popov ${ }^{75}$; Aleksandr Abliessimov"76; Mikhail Matínski ${ }^{77}$; e

72 Charles Simon Favart (1710-1792) - ele foi a ponte da transformação de vaudevilles em verdadeiras óperas-cômicas. Suas peças trabalhavam com temas e situações diversas. A trama retratava, na maioria das vezes, dois camponeses apaixonados tentando ultrapassar obstáculos à sua união. Algumas de suas peças: Le caprice amoureux, ou Ninette à la cour (1755), Annette et Lubin (1762), Les moissonneurs (1768)

73 Jean-Jacques Rousseau (1712-1778) - importante pensador e escritor francês, cujas obras Les confessions e La nouvelle Héloise são destaque. No caso das óperas-cômicas, o grande nome é Le devin du village, de 1752.

${ }^{74}$ Michel-Jean Sedaine (1719-1797) - autor francês de óperas-cômicas, tal como Le déserteur (1769).

${ }^{75}$ Mikhail Popov (1742-1790) - dramaturgo e jornalista russo

76 Aleksandr Abliessimov (1742-1783) - dramaturgo russo, criador de uma das duas óperas-cômicas mais famosas da época, Мельник колдун, обманщик и сват (Mel'nik koldun, obmanschik i svat, O bruxo moleiro, enganador e casamenteiro, 1779).

77 Mikhail Matínski (1750-1820) - dramaturgo russo, criador de uma das duas óperas-cômicas mais famosas da época, Санктпетербургский Гостиный двор 
Iakov Kniájnin ${ }^{78}$, sendo este último um dos grandes pavimentos que sedimentariam o terreno para que Chakhovskói, Khmielnitski e, no ápice, Griboiédov, criassem suas obras.

Também escritor de óperas-cômicas (escreveu, ao todo, cinco óperas-cômicas, sete tragédias, poemas, sátiras, e quatro comédias), Kniájnin aprimorou muito o universo da versificação em comédias. Suas obras, Хвастун ${ }^{79}$ (Khvastun, O fanfarrão, 1786) е Чудаки (Tchudáki, Os excêntricos, 1790), podem ser consideradas grande ponto de partida para o que veríamos surgir mais adiante na comédia russa. Nessas peças, há uma tentativa em incorporar provérbios e aforismos, características que tanto engrandecem a obra de Griboiédov. Apesar de não conter a estética final dos versos de Gorie ot uma, as comédias de Kniájnin possuem, ao menos, a tentativa de solucionar problemas de fluência no diálogo em versos que foram, com o passar do tempo, melhor aproveitados pelos dramaturgos subsequentes.

(Sanktpieterburgskii Gostinyi dvor, Galeria com lojas de São Petersburgo,1779). Nesta obra, o uso do dialeto da classe média urbana, em propósito literário, era muito inovador, proporcionando, ao futuro, as peças de Chakhovskói; O casamento, de Nikolai Gógol; e as peças de Aleksandr Ostróvski.

78 Iakov Kniájnin (1742-1791) - dramaturgo russo, com uma significativa e muitas vezes polêmica trajetória. Sua tragédia, Вадим Новгородский (Vadim Novgorodskii), foi uma grande polêmica na época, tornando-se um dos primeiros textos, considerados subversivos, a frequentar círculos secretos. Catarina II mandou que vasculhassem e capturassem todos os exemplares da obra, a fim de mandá-los ao fogo.

79 Mesmo após o aparecimento de Gorie ot uma, o crítico da época, Príncipe Piotr Viazemski (1792-1878), ainda considerava a comédia Хвастун (Khvastun, O fanfarrão) como a melhor comédia russa até então. 
Passados os dramaturgos precursores, junto à evolução da língua literária russa ${ }^{80}$, o esculpir de uma versificação de maior fluência e ritmo, o uso do russo coloquial, e a criação, adaptação e afrouxamento das regras neoclássicas, deparamo-nos com o terreno contemporâneo a Griboiédov, e do qual ele fez parte como escritor secundário e, em sequência, como um dos maiores gênios literários a surgir até então.

A comédia ainda versava sobre uma temática fortemente neoclássica. O universo em que ela se afigurava era, com firmeza, como nos diz Voltaire,

uma mistura de seriedade e de gracejos, de cômico e de comovente. É assim que a vida dos homens está matizada; muitas vezes mesmo uma única aventura produz todos estes contrastes. Nada é mais comum que uma casa na qual um pai resmunga, uma filha arrebatada pela sua paixão chora, o filho zomba dos dois, e alguns parentes tomam parte na cena de maneiras diferentes. Troça-se muitas vezes num quarto do que enternece no quarto vizinho, e a mesma pessoa algumas vezes riu e chorou pela mesma coisa no mesmo quarto de hora. ${ }^{81}$

Nessa pequena descrição do gênero, por Voltaire, conseguimos identificar muitos dos enredos das comédias

\footnotetext{
${ }^{80}$ Sobre a língua literária russa, em seus rudimentos: ("A história da língua literária russa, na segunda metade do século XVIII e as primeiras duas décadas do século XIX, é a história da liberação gradual dos eslavismos artificiais em arcaicos no léxico, gramática e sintaxe, dos vestígios da linguagem chancelada dos escribas moscovitas (posteriormente reavivadas como efeitos especiais pelos poetas do século XX (...) Karamzin e seus discípulos literários (incluindo o jovem Púchkin) buscaram "escrever como as pessoas falam" - significando como as pessoas de gosto e cultura falavam e, particularmente a mulher (...) que eles perceberam, 'seu principal leitor." (FIGES, Orlando. Natasha's Dance: a cultural history of Rússia. New York: Picador, 2002, p. 51.)

81 VOLTAIRE. "A mistura dos géneros". "Obras completas". (org. Monique Borie, Martine de Rougemont, Jacques Scherer). In: Estética Teatral: textos de Platão a Brecht. tradução de Helena Barbas. Lisboa: Fundação Calouste Gulbenkian, 2004. p.151-152.
} 
neoclássicas russas e, inclusive, na obra-prima de Griboiédov. E, sendo assim, mesmo ofertando-nos uma brilhante estrada no universo da palavra, Gorie ot uma ainda é caminho a seguir, e é somente nas transfigurações totais do gênero, em Gógol, que podemos perceber o quanto ele estava à frente de seu tempo. $O$ inspetor geral é a ruptura definitiva.

No entanto, nos primeiros anos do século XIX, o gênio Gógol ainda estava longe do brilho. Mas um nome, carregado por uma figura irascível e polêmica ${ }^{82}$, despontava no meio teatral: Aleksandr Chakhovskói (1777-1846). Em toda a sua vida, Chakhovskói escreveu cento e onze peças, dentre elas, tragédias, óperas-cômicas, vaudevilles, comédias em verso e em prosa. À parte das polêmicas envolvendo os conflitos contrários entre os grupos Беседа (Besiedá) - do qual fazia parte -, е Арзамас ${ }^{83}$ (Arzamas), Chakhovskói foi um

82 Chakhovskói foi acusado, por muitos, de ter provocado o fim trágico do dramaturgo Ozierov. Ele foi um dos grandes nomes do grupo literário Беседа, símbolo de todo o pensamento reacionário e conservador da época.

83 A dicotomia dos grupos Беседа (Besiedá) е Арзамас (Arzamás) envolve todo o primeiro quarto do século XIX. Segundo Brown, o estudo pioneiro acerca do assunto provém de Iuri Tyniánov. Sem usar as especificações de Tyniánov, e de modo simplista, Brown afirma que "quando Karamzin e a sua escola de escritores sentimentalistas ou pré-românticos introduziram seus novos usos linguísticos revolucionários (...) uma reação conservadora insurgiu-se entre os classicistas, que, indignamente, recusaram as inovações e defenderam a velha linguagem literária com suas numerosas relíquias da Velha Igreja Eslavônica. De acordo com essa teoria, Aleksandr Chichkov, o líder da reação, representava o Classicismo em seu lado mais conservador e Karamzin, o Romantismo em seu lado mais revolucionário; as visões reacionárias políticas de Chichkov foram simplesmente transferidas para a esfera linguística. Em termos marxistas, o Karamzinismo era progressista, Chichkovismo era reacionário". Tyniánov, em sua análise, afirma que a distinção fundamental instala-se na ideia do arcaico e do novo. (Brown, William E. A history of russian literature of the Romantic Period: Volume One. Michigan: Ardis Publishers, 1986. p. 26.); Quanto às sociedades, o Índice de nomes e referências (2004, cit.) diz que, em suma, a sociedade literária Arzamas, fundada em 1815 por N. Karamzin, V.A. Jukóbski, K. Bátiuchkov e P. A. Viázemski defendiam uma abertura para com as influências literárias da Europa. Pode-se dizer 
grande dramaturgo da época. Suas melhores peças foram publicadas e ofertam, à posteridade, uma noção de sua contribuição para com o teatro no século XIX.

Acreditava em uma dramaturgia construída a partir da prática dos "retratos" sociais - uma das grandes críticas a Gorie ot uma -, ou seja, dos tipos sociais. Segundo Tyniánov, "um retrato" era, antigamente, para a comédia russa não uma exceção, mas uma regra. A prática de retratos começou com Krylov, ganhando força com Chakhovskói e, depois, desenvolvida por Katenin. Na comédia de Chakhovskói, Новый Стерн (Novyi Stern, O novo Stern)) (1807), havia a caricatura de Karamzin em Fiálkin e, em uma de suas outras peças, Urok koketkam, ili Lipietskie vody (Lição para Coquetes, ou A estância Lipietski, 1815) - ele criou uma caricatura de Jukóvski ${ }^{84}$. Mais à frente, veremos como essa representação de indivíduos reais em personagens apareceu, com força, em Griboiédov.

Quanto a Chakhovskói, a primeira obra de sucesso foi a peça Новый Стерн (Novyi Stern, O novo Stern, 1805). O conde Pronski, a personagem principal da comédia, apaixona-se por Melania, a filha de um moleiro. Apesar da diferença social, e de Melania estar enamorada de outro, ele estava determinado em se casar com ela. Em diversas peripécias que se misturam ao enredo, Pronski percebe

que Griboiédov, como partidário do grupo contrário ao Arzamás, era, portanto, partidário do arcaico, reacionário ("Índice de Nomes e Referências", 2004, cit., p. 218).

${ }^{84} \mathrm{O}$ caso de Jukóvski marcou, segundo Tyniánov, o início do círculo literário Arzamás e a emergência da famosa controvérsia literária entre "Arzamas" e "Besieda". 
seus erros e volta para casa a fim de permanecer no local da sociedade que the é devido. ${ }^{85} \mathrm{~A}$ peça consegue, ainda que com sua brevidade, ser divertida e, também, ser portadora de efeitos cômicos refinados. ${ }^{86}$

Após alguns anos de obras menores, e passado o período da guerra de 1812, Chakhovskói ressurge com uma de suas primeiras peças significativas: Урок кокеткам, или Липецкие воды (Urok koketam, ili Lipietski vody (Lição para Coquetes, ou A estância Lipietski) (1815). Segundo Karlinsky, não poderíamos jamais pensar tratar-se de um exagero ao mencionarmos Урок кокеткам...(Lição para Coquetes, ou A estância Lipietski) como uma nova porta no universo do Teatro Russo. A comédia, escrita em cinco atos, observa com rigor as regras clássicas de unidade: decorre em apenas um dia, em um espaço entre dois chalés, em uma estância de águas ${ }^{87}$. Mas, ainda assim, consegue utilizar-se das regras de maneira brilhante.

A fábula da peça é: condessa Lelieva, uma coquette astuciosa, apesar dos numerosos pretendentes, decide conquistar o coronel Pronski, que acaba de retornar da campanha de 1812, e está apaixonado por Ólienka, a irmã de seu amigo Kholmski. Há, portanto, uma 'batalha' entre Kholmski e Lelieva, para ver quem manipula mais o relacionamento entre Pronski e Ólienka. Ólguin, um dos

\footnotetext{
${ }^{85}$ Brown, 1986, cit., p. 66.

${ }^{86}$ Como o próprio autor confirma, na introdução da peça, o enredo de Новый Стерн (Novyi Stern, O novo Stern) tem influência na comédia de Molière, Le Bourgeois gentilhomme.

87 A peça se passa em Tambov - uma famosa estância de águas, desde o reino de Pedro, o Grande, por seus poderes de cura.
} 
pretendentes de Lelieva, figura como uma das partes nesse entrecho repleto de cinismo e coquetismo. Para completar, a criada Sacha, a soubrette ${ }^{88}$, cujas artimanhas trabalham, durante toda a obra, para o final feliz. O título da comédia provém de uma obra menor francesa, La coquette corrigée (1756), escrita por de la Noue, e há fortes indícios de semelhança entre a condessa Lelieva e a Célimene (Le misanthrope) de Molière.

Segundo Brown, a forma com que Chakhovskói desenvolve o enredo faz com que a peça seja classificada como uma obra-prima, principalmente devido à habilidade com que os versos misturam a linguagem coloquial, em um ritmo cômico. Sendo assim, o dramaturgo consegue aproximar-se muito da flexibilidade e naturalidade de Gorie ot uma. Em Урок кокеткам (Urok koketam, ili Lipietski vody, Lição para Coquetes), Griboiédov obteve um bom panorama do que poderia desenvolver mais adiante ${ }^{89}$.

Outra obra significativa de Chakhovskói teve forte importância para o crescimento de Griboiédov como dramaturgo. Só que, dessa vez, não apenas em influência, posto que ele foi um dos co-autores ${ }^{90}$. Trata-se de Своя семья, или замужняя невеста (Svoia

\footnotetext{
${ }^{88}$ Soubrettes são as criadas das comédias francesas neoclássicas e tinha características tradicionais: eram espertas e resolviam as situações por meio de diversas peripécias e artimanhas.

${ }^{89}$ Brown, 1986, cit., p. 71.

${ }^{90} \mathrm{Na}$ introdução da peça, Chakhovskói escreve: "(...)Havia um curto período até o dia estabelecido como para o espetáculo, e, por medo de não manter minha promessa, pedi a Aleksandr Griboiédov e Nikolai Khmielnitski para me ajudarem. Pela amizade que me devotavam, eles concordaram; o primeiro escreveu o início todo do Segundo ato até a saída de Fiókla Savvishna, e o Segundo escreveu uma cena do terceiro ato em que Biriulkin faz uma análise de Natácha. Tanto a gratitude
} 
semia, ili zamujniaia nievesta; Sua família, ou a noiva casada, 1817).

A comédia, escrita em três atos, em verso, foi composta, em sua maior parte, por Chakhovskói, e o restante, por Griboiédov ${ }^{91}$ e Khmielnitski ${ }^{92}$.

A peça, sem dúvida, foi o maior sucesso de público, em comédias, de Chakhovskói. As numerosas encenações atravessaram o século XIX, e a colaboração ${ }^{93}$ de nomes importantes do teatro de então, notadamente o de Griboiédov, ofertaram à peça um caráter irresistível. A trama consiste: um jovem órfão, Liúbim, casa-se, secretamente, com Natácha, uma moça pobre, que fora criada por uma família da aristocracia. O rapaz é herdeiro de uma fortuna que só Ihe será entregue se a esposa escolhida for aprovada por um grupo de seus parentes. Cada um deles possui uma ideia definida de como deve ser a noiva de Liúbim. A tarefa de Natácha, na peça, é de convencer o grupo de que ela é a melhor escolha e, para tal, utilizase de sua imaginação intrépida, repleta de artimanhas. ${ }^{94}$

Para o desenvolvimento da língua literária que veríamos exposta em Gorie ot uma, podemos rememorar mais uma obra de

quanto a justiça fazem com que eu coloque isso em conhecimento público, para, asim, não usurper propriedade alheia". (Karlinsky, 1985, cit., p. 240, Tradução Nossa)

${ }^{91}$ Griboiédov escreveu as cenas de 1-5 do Ato II.

${ }^{92} \mathrm{Khmielnitski}$ escreveu a cena 3 do Ato III.

93 Apesar das colaborações de Griboiédov e Khmielnitski, a peça possui um caráter unificado e, sendo assim, ao lê-la, dificilmente, percebe-se de que há mais de um autor envolvido em sua composição. No entanto, em 1953, um crítico chamado Ievreinov afirmou ser Своя семья... (Sua família...) uma peça, pouco conhecida, de Griboiédov. (Karlinsky, 1985, cit., p.244)

94 Uma das artimanhas de Natácha é fingir-se de empregada na casa de uma das tias avarentas de Líubim. Ela a impressiona apresentando uma receita de bolo de cenoura que quase não usa açúcar. Essa cena foi escrita por Griboiédov.(Karlinsky, 1985, cit., p. 241) 
Chakhovskói: Не любо - не слушай, а лгать не мешай (Nie liuba nie sluchai, a Igat nie mechai, 1818). O próprio título tornou-se um provérbio do idioma russo, mas a comédia só, em um único ato, é apenas uma criação simplista. O que realmente torna-se essencial nessa peça é a versificação, em iambos de variados tamanhos. Uma das rupturas à tradição clássica já estava acontecendo, portanto Griboiédov encontrou terreno aberto para sua produção em versos livres. ${ }^{95}$

$$
\begin{aligned}
& \qquad * * * * * * \\
& \text { Em relação ao conteúdo da obra de Griboiédov, é necessário } \\
& \text { mencionarmos um pouco acerca de Nikolai Khmielnitski, seu } \\
& \text { companheiro na criação, junto de Chakhovskói, de Своя семья, или } \\
& \text { замужняя невеста (Svoia semia, ili zamujniaia nievesta; Sua família, }
\end{aligned}
$$
ou a noiva casada, 1817).

Khmielnitski (1789-1845) tornou-se conhecido, no universo teatral russo, primeiramente, pelos seus vaudevilles ${ }^{96}$ e pelas pequenas comédias produzidas entre 1817 e 1829. Ele inicia sua

\footnotetext{
${ }^{95} \mathrm{Na}$ seara da tragédia, os versos iâmbicos de variados tamanhos já havia aparecido em Kniájnin, em The clemency of Titus, ainda no século XVIII (Karlinsky, 1985, cit., p. 245)

${ }^{96} \mathrm{O}$ vaudeville é uma híbrida junção com raízes na ópera-cômica e na comédie larmoyante - "reuniu, quase exclusivamente, um público de classe baixa, e foi encenado em um teatro especial construído para sua instalação em 1792. O vaudeville era uma comédia em prosa livremente construída, intercalando danças, pantomimas e canções. As canções eram usualmente paródicas, satíricas e atuais. Elas, frequentemente, zombavam de figures públicas, políticas e literárias, e os versos dessas canções (chamadas de "pares") alcançavam, às vezes, uma qualidade literária real de uma sátira espirituosa e aguda". (Brown, 1986, cit., p. 61.)
} 
carreira no mundo da literatura após retornar de Paris e, juntamente

à carreira civil, forma uma cadeia de conhecidos que farão parte de seu desenvolvimento no teatro - entre eles, Griboiédov, Chakhovskói, Katenin e Púchkin ${ }^{97}$.

Além do excerto, na peça escrita em conjunto, é interessante relembrar uma obra de Khmielnitski, considerada uma das grandes antes de Gorie ot uma - Говорун (Govorun; O tagarela, 1817) -, e que será importante modelo para Griboiédov. A trama traz o Conde Zvonov, que corteja a jovem viúva Preliestina. Ele a perde para o jovem oficial Modiestov, porque não consegue frear seu impulso em dominar, transgredir e atrapalhar toda e qualquer conversação. ${ }^{98}$

Khmelnitski, bem como Chakhovskói, teve importância fulcral nos pavimentos do teatro pré-Gorie ot uma. Mais alguns nomes os seguiram: Kapnist ${ }^{99}$, Katenin (que escreveu uma peça com Griboiédov, a ser mencionada mais adiante) ${ }^{100}$, Kokochkin ${ }^{101}$. Para Belínski (1839),

Após as comédias de Fonvízin, a comédia Ябеда (Iabieda, A denúncia), de Kapnist, fez um pouco de barulho, mas seu produto, em um sentido literário, não merece qualquer atenção. Seu sucesso baseia-se não

\footnotetext{
97 KARLINSKY, Simon. Russian drama: from its beginning to the age of Púchkin. Califórnia: University of Carolina Press, 1985. p. 250.

${ }^{98}$ A trama e suas personagens serão modelos não apenas para Griboiédov, mas também para Púchkin, em Evguiéni Oniéguin, e Gógol - "Como afirmou Mosei Iankóvski, o editor da mais recente publicação de suas peças, 'Ao relermos essas peças longamente esquecidas, nós nos surpreendemos ao ouvir nelas as entonações que parecerão, novamente, mais fortes e significantes em Evguiéni Oniéguin e Gorie ot uma."' (ibidem, p. 252)

99 Vassíli Kapnist (1757-1824) - dramaturgo russo. Sua peça mais significativa, Ябеда (Iabieda; A denúncia, 1798).

100 Pável Katenin (1792-1853) - dramaturgo russo. Uma de suas peças: Андромаха (Andromakha, 1827).

${ }^{101}$ Fiódor Kokoshkin (1773-1838) - dramaturgo e ator russo.
} 
em seu propósito literário ou qualquer espécie de dignidade, (...) A trama, a intriga e o desenlace banais, os versos desajeitados, e a língua de um barbarismo livresco ${ }^{102}$.

Sem desvencilharem-se totalmente do universo neoclássico, eles ensinaram Griboiédov a utilizar-se das regras de maneira inventiva, adensando a psicologia das personagens, a fluência da língua, o transcorrer do tempo e do espaço. À parte do crivo do tempo, que leva os menores ao esquecimento, Púchkin os fixou em mármore eterno. Escreveu uma parte, no Capítulo II de seu Evguiéni Oniéguin, um pequeno mural que relembra alguns destes nomes:

XVIII
Terra encantada! Lá brilhou
Fonvízin mestre consumado,
Sátira fez, no que primou,
Da liberdade apaixonado;
Também Kniazhnin, adaptador
Lá Ozerov, de teatro autor,
Que aplauso e pranto dividiu,
Com Semionova, seu brio;
E Katenin logo animou-se
De Corneille, gênio grandioso;
Lá Shakhovskoi, mordaz, ruidoso;
Lá Didelot, glorificou-se;
Lá bastidores abrigaram
Meus jovens anos que
passaram. ${ }^{103}$

XVIII

Волшебный край! там в стары годы, Сатиры смелый властелин, Блистал Фонвизин, друг свободы, И переимчивый Княжнин; Там Озеров невольны дани Народных С младой Семеновой делил; Там наш Катенин воскресил Корнеля гений величавый; Там вывел колкий Шаховской Своих комедий шумный рой, Там и Дидло венчался славой, Там, там под сению кулис Младые дни мои неслись.

102 Belínski, 1839, trecho em tradução nossa.

103 PÚCHKIN, Aleksandr. Eugênio Oneguin. trad. Dário Moreira de Castro Alves. Moscou: Grupo Editorial <<Azbooka-Atticus >>, 2008. pp. 42-43. 


\section{O caminhante}

A vida de Aleksandr Serguéievitch Griboiédov segue o destino dos mitos. Como Púchkin, a curta existência, as grandes obras delegadas à posteridade, esfumaçam-Ihes a personalidade, fazendonos pensar o quão difícil é torná-los humanos. O que nos chega, no entanto, são suas palavras. De Púchkin ${ }^{104}$, a força da palavra, em lírica, prosa e drama. De Griboiédov, Gorie ot uma.

Sua personalidade ${ }^{105}$ continua apenas difundida pelas cartas que trocou com diversos de seus amigos, durante os anos em que chegou a São Petersburgo, onde começou a carreira artística, até o período em que se firmou como diplomata. Uma interessante visão do homem Griboiédov, provém de Iuri Tyniánov ${ }^{106}$, um dos maiores pesquisadores russos do dramaturgo. Em carta a Górki, Tyniánov afirmou ser Griboiédov o homem mais melancólico dos anos 20, no século XIX. ${ }^{107}$

Griboiédov nasceu no final do século XVIII, em 4 de janeiro de 1795. Segundo alguns livros de registro - uma questão ainda

104 Ficamos com as interessantes palavras de Vsevolovski "Enquanto Púchkin mostrava ao seu povo os melhores elementos do caráter nacional, Griboiédov mostrava uma maneira realista do lado obscuro de suas vidas. Ele veio, no entanto, não como um pregador em uma vestimenta solene; ele veio como um amigo que zomba das enfermidades e vazio da classe alta." (MOISSAYE, J. O. Guide to Russian literature (1820-1917). New York: Harcourt, Brace and Home, 1920, p.22.)

105 Nas lembranças dos contemporâneos ao escritor, muito foi dito acerca de sua personalidade. Cf. obra VÁRIOS AUTORES. A.S. Griboiédov v vospominániakh sovriemiênikov. Moskva: Khudojestvenaia Litieratura, 1980.

106 Iuri Tyniánov (1894-1943) escreveu duas obras sobre Griboiédov: um ensaio, Сюжет "Горя от ума"; e uma biografia romanceada, Смерть Вазир-Мухтара.

107 NAZARIENKO, M. "Tyniánov o Griboiedovie: nauka i litieratura". Russki Izyk, litieratura, kul'tura v chkolie i vizie (K.), 2006, N.4, p. 17-21. 
imprecisa -, há ainda a possibilidade de Griboiédov ter nascido um ano antes, em $1794^{108}$. Proveniente de uma família nobre, mas com muitas dificuldades econômicas, ele era filho do Major Serguei Ivánovitch Griboiédov e Anastássia Fiódorovna. A mãe, figura firme e autoritária, exerceria grande influência no desenvolvimento da personalidade do futuro artista e de sua irmã mais nova, Maria - que nasceria quatro anos depois de Griboiédov. Fato desconhecido a todos os biógrafos é, talvez, a possível existência de outra irmã de Griboiédov, Sófia, que, segundo alguns documentos avaliados recentemente comprovam ter, talvez, morrido na infância ${ }^{109}$.

A mãe, apesar de todo o temperamento, não poupava esforços para apresentar os filhos às pessoas certas. Uma de suas irmãs casou-se com o Ministro da Educação, conde Razumósvki ${ }^{110}$, enquanto seu irmão, Aleksei Fiódorovitch, era um rico proprietário de terras. Griboiédov, notando a personalidade forte do tio, escreveu um pequeno texto, Характер моего дяди (Kharakter moevo diadi, O caráter de meu tio), acerca de seus modos de receber as pessoas em sua casa, de como cortejar as moças, enfim, de como ser um nobre comme il faut. ${ }^{111}$ Por intermédio de seu tio, Griboiédov pôde conhecer

\footnotetext{
108 Tal hipótese surgiu no trabalho de análise de A.I. Reviákin aos livros de registro da Igreja da Assunção, no forte de Ostojenka Pretchistienski (Cf. ensaio sobre as novas descobertas acerca da vida de Griboiédov: MESCHERIAKOV, V.N. Novoie o Griboiédovie, Russkaia $\quad$ Litieratura, No.1, 1985. http://az.lib.ru/g/griboedow_a_s/text_0120.shtml, primeiro acesso em $15 / 01 / 2010$ )

${ }^{109}$ Cartas de Nastássia Griboiédova: MESCHERIAKOV, 1985, ibidem.

110 Os Razumóvskis eram favoritos da Imperatriz Ielizavieta (1709-62).

111 "(...)Todos possuíam o espírito da desonestidade em suas almas, e engano em suas línguas. Parece-nos que, agora, não é mais o acaso - mas meu tio pertenceu
} 
e conviver com o mais refinado estrato da aristocracia russa. É natural, portanto, que aquele ambiente pudesse, talvez, ofertar-lhe um sentimento de admiração ou de repulsão. No entanto, o que mais nos interessa é a forma com que, em versos, ele soube transpor as personagens reais em elementos artísticos.

Aos oito anos, ele entrou no Pensionato dos Filhos da Nobreza, em Moscou. Para completar sua formação, ele também possuía um tutor alemão, Johann Petrosilius ${ }^{112}$. Pouco tempo se passou para que Griboiédov terminasse os estudos básicos e fosse admitido na Universidade. Sendo assim, aos onze anos, em janeiro de 1806, ele iniciou sua formação na Universidade de Moscou. Lá, ele pôde estudar diversos assuntos, entre eles: Literatura e Gramática grega; Poesia e Retórica Russa; História Mundial; História e Geografia do Império Russo; línguas orientais; e mais francês, alemão e inglês. ${ }^{113}$ Finalizados os iniciais estudos de graduação, Griboiédov partiu para a Faculdade de Direito, na qual obteria o grau aos quinze. ${ }^{114}$

Bem como a formação intelectual, o interesse pelo teatro também surgiu cedo na vida de Griboiédov. Seu novo tutor, a

àquela época. Ele lutou como um leão contra os turcos sob Suvorov, então foi bajular aqueles em proteção, nos salões, em São Petersburgo e, em sua aposentadoria, viveu longe das fofocas. Sua favorita advertência moral era, "Como vejo, meu caro amigo."(KELLY, Laurence. Diplomacy And Murder In Tehran:

Aleksandr Griboyedov And Imperial Russia's Mission To The Shah Of Persia. London: I.B. Tauris Publishers., 2002, trecho em tradução nossa, p. 10.)

112 Lembrar-se de que Tchátski, no primeiro Ato da peça, menciona o seu tutor alemão.

113 Op.cit, p.11

114 Aos quinze anos, Griboiédov já tinha completado sua formação. Seus gostos e julgamentos literários já estavam formados: apreciava Shakespeare, Schiller, Goethe e Voltaire. Apesar do medo acerca das ideias do Iluminismo - que alcançaram a Rússia após a Revolução Francesa -, ele começou a questionar as próprias instituições de seu país. (op.cit., p.12) 
substituir Petrosilius, Johann John, era um amante do teatro. Assim, já no período estudantil, Griboiédov pôde intentar-se nas searas da dramaturgia, e sua primeira peça foi uma adaptação da tragédia de Ozierov, Дмитрий Донской (Dmitrii Donskoi).

Nessa época de estudos, Griboiédov travou conhecimento com algumas figuras principais do Movimento Dezembrista, o qual de maneira polêmica, mas de realidade duvidosa, passou a ser associado. Entre as figuras: Artamon Muravióv, Nikolai Turguéniev, Serguei Trubiétskoi - todos eles exilados na Sibéria, devido à participação na sublevação.

E, com alguns deles - diferente de muitos colegas estudantes que partiram para Nijni Novgorod -, voluntariou-se no exército, junto aos hussardos ${ }^{115}$, quando da invasão napoleônica, em 1812. No entanto, quando o regimento partiu para Kazan, no momento da chegada das primeiras tropas francesas, Griboiédov adoeceu e foi dispensado, caminhando, assim, para a propriedade de sua família a fim de se restabelecer. Ele pôde retornar apenas em maio de 1813, quando se juntou a um regimento de Irkutsk, em Kobrin. Griboiédov retornou, somente no final de 1815, à vida civil e, em 25 de março de 1816, obteve a dispensa oficial do serviço militar.

No final de 1815, o major Griboiédov, pai de Aleksandr, morreu. Com inúmeras dívidas, a família viu-se em pior situação.

\footnotetext{
115 "Os hussardos de Moscou haviam sido criados pelo imensamente rico Conde P. I. Saltikov, um oficial aposentado da cavalaria que servira na Guarda e que, por motivos de puro patriotismo, solicitou a permissão do czar para levantar um regimento às suas próprias custas". (op.cit., p.18, trecho em tradução nossa)
} 
Mesmo assim, em busca de possibilidades mais amplas, ele partiu para São Petersburgo, junto de seu melhor amigo - que conhecera na época da campanha napoleônica -, Beguitchov. Tendo escrito artigos - enviados a jornais e bem recebidos em Moscou e São Petersburgo -, nos últimos anos, Griboiédov passou a planejar formas para adentrar a carreira literária.

Sua primeira peça encenada, já na fase adulta, foi uma adaptação de Le Secret Du Ménage (1809), de Creuzé de Lesser. Em russo - Молодые супруги (Molodye suprugui). Chakhovskói, que o conhecera em 1813, incentivou-o a escrever a peça e, assim, a amizade possibilitou, futuramente, a parceria em, como vimos anteriormente, Своя семья, или замужняя невеста (Svoia semia, ili zamujniaia nievesta, 1817).

Молодые супруги (Molodye suprugui, Os jovens cônjuges), uma comédia de um ato, foi encenada em São Petersburgo em 1815 - na mesma época em que Урок кокеткам, или Липецкие воды (Urok koketkam, ili Lipietskie vody) estreou, com grande sucesso -, e, no ano seguinte, em Moscou. A história assume caráter convencional e inócuo, não portando qualquer peculiaridade significativa.

Nessa época, Griboiédov conhece Pavel Kátenin e, com ele, escreveu, em 1817, uma nova comédia em prosa - Студент (Studient; O estudante). A peça não passou pelos censores, até ser encenada na década de 60 , século XIX. A trama segue a trajetória de 
um estudante, vindo de Kazan, que busca, sem sucesso, uma carreira literária e um casamento, em São Petersburgo.

O ano de 1817 foi decisivo para Griboiédov e, principalmente, porque tomou parte em um famoso duelo. Zavadóvski, em cuja casa Griboiédov morava, e Cheremietiev, um cavalheiro da guarda, duelaram-se em nome de uma famosa dançarina de nome Istomina.

Griboiédov, em toda a sua vida, sentiu-se implicado e, por vezes, culpado pelas consequências ao duelo, por ter sido o estopim para que Zavadóvski conhecesse e se apaixonasse por Istomina, amante de Cheremetiev. A paixão entre esses últimos era tão voraz e violenta que, antes do evento fatídico, levara Cheremetiev às portas do suicídio. Ainda que a presença do ex-amante fosse constante em sua vida, como uma espécie de eterna vigília aos seus atos, Istomina conheceu Zavadóvski, por intermédio de Griboiédov, e, assim, aproximou-se dele de forma amorosa. O simples encontro entre ambos culminou em um duelo que mancharia para sempre a imagem de Griboiédov. Para Púchkin, seriam esse evento e a Revolta Dezembrista as grandes forças polêmicas que assolaram a vida de Griboiédov. Nem o campo de estudo literário nem o diplomático foram o bastante para marcar sua trajetória, enquanto vivia. "Houve profundas impressões da vida pessoal, da experiência de vida. Púchkin, que se deparou com seu corpo, prostrado em uma carroça, enquanto voltava de viagem, lembrou-se de que o que se concluiu exatamente do papel da difamação na vida de Griboiédov é que: 
"nascido com ambição, igual ao seu talento, ele foi entremeado por muito tempo em redes de necessidades triviais e incerteza. O talento do poeta não foi reconhecido, pois até mesmo sua coragem, fria e brilhante, permaneceu por um tempo sob suspeita" ${ }^{116}$. Tyniánov nos relembra de que, no excerto de Púchkin, fala-se sobre o famoso duelo, que culminou na morte, em 1817, de Cheremetiev. Depois, as consequências advindas desse evento fatídico e a saída forçada de Moscou transformaram-se, em 1820, no que Griboiédov chamou de exílio político. Isso tudo sem levarmos em conta as problemáticas que surgiram após dezembro de 1825 e as implicações com a Revolta Dezembrista ${ }^{117}$.

Nunca se soube, ao certo, o que se sucedeu naquele dia de novembro de 1817 , mas, sabe-se que Iakubovitch, o quarto membro do que era chamado partie carrée ${ }^{118}$, figura irascível, postou-se ao lado de Cheremetiev e, Griboiédov, junto a Zavadóvski. No decorrer do duelo, temendo pelo fim, Zavadóvski pede reconsideração pela parte oponente e, certo de uma tentativa frustrada, acaba por atingir o estômago de Cheremetiev, provocando-Ihe uma ferida fatal.

Na época, no entanto, o duelo era proibido na Rússia, assim como em outros países e, para tal, é aberto um inquérito. As

\footnotetext{
116 PUCHKIN, Apud Tyniánov, 1968, trecho em tradução nossa.

117 Tyniánov, 1968, trecho em tradução nossa.

118 Geralmente, o termo "partie carrée" é usado quando de uma quadra amorosa. No contexto em que Kelly relaciona o "partie carrée" em um duelo é, talvez, para especificar a relação de duplas em um duelo.
} 
sentenças são, ao final, leves, mas a mancha permanece intacta e Griboiédov é enviado da capital para um posto no estrangeiro.

A figura central do duelo, Istómina, foi imortalizada por versos de Púchkin, em Evguiéni Oniéguin:

$\mathrm{XX}$

\begin{tabular}{l|l}
\hline Casa lotada; um esplendor, & Театр уж полон; ложи блещут; \\
Poltronas, frisas, fervilhando; & Партер и кресла - все кипит; \\
Torrinha inquieta, que rumor, & В райке нетерпеливо плещут, \\
E o pano sobe, farfalhando. & И, взвившись, занавес шумит. \\
Um tanto etéreo, refulgindo, & Блистательна, полувоздушна, \\
Ao arco mágico seguindo, & Смычку волшебному послушна, \\
De muitas ninfas já cercada, & Толпою нимф окружена, \\
Eis surge Istómina, parada, & Стоит Истомина; она, \\
De leve um pé firma no chão, & Одной ногой касаясь пола, \\
Е o outro gira gracilmente, & Другою медленно кружит, \\
Eis salta, voa de repente, & И вдруг прыжок, и вдруг летит, \\
Qual pluma ao sopro eólio, então & Летит, как пух от уст Эола; \\
Torce a cintura e o sutil porte, & То стан совьет, то разовьет \\
Com um pé no outro bate forte.
\end{tabular}

$* * * * * * *$

Em 1818, Griboiédov sai de São Petersburgo, rumo à carreira na Diplomacia, junto ao Ministério do Exterior. A ideia era que fosse

119 PÚCHKIN, Aleksandr. Eugênio Oneguin. trad. Dário Moreira de Castro Alves. Moscou: Grupo Editorial <<Azbooka-Atticus>>, 2008. pp. 43-44. 
para o consulado na Filadélfia, mas os planos eram transformar a fachada diplomática em exílio. Ainda que já avançasse nos estudos do idioma e história persa, Griboiédov não imaginava o porquê de tanta distância, como se assim pudesse antever seu trágico destino. ${ }^{120}$

Para aproveitar ao máximo os últimos períodos em São Petersburgo, ele faz uma tradução retrabalhada de uma comédia francesa chamada Les fausses infidélités -, e em russo, Притворная неверность (Pritvornaia nevernost, Traição simulada), foi encenada, em São Petersburgo, em 1818, logo após sua partida. Profundamente clássica, a peça abarca apenas cinco personagens, embaralhadas em uma teia amorosa, na decorrência de apenas um ato. No entanto, a peça trazia uma novidade em relação às anteriores. Além dos versos, a comédia continha músicas que foram, possivelmente, compostas por ele. ${ }^{121}$

Antes de partir para Teerã, Griboiédov retornou à Moscou, em agosto, para visitar a família. No meio de setembro, estava a caminho da Pérsia e do Cáucaso.

\footnotetext{
${ }^{120}$ Griboiédov em carta a Bieguitchov - "Eu Ihe disse que não concordaria a menos que me dessem uma promoção dupla no momento em que fui indicado para o Teerã. Ele contraiu o rosto em dúvida, e então eu tentei convencê-lo, em meu belo francês, de como seria perverso passar o florescer da minha juventude e os meus dias mais criativos entre asiáticos de comportamentos selvagens, em uma espécie de exílio involuntário". (Kelly, 2002, cit., p.40)

${ }^{121}$ Griboiédov foi criado em um ambiente que prezava muito a música e ele mesmo é um compositor - "Nós sabemos, por seus contemporâneos, o quão brilhantemente ele tocava e improvisava no piano; seus compositores favoritos eram Weber and Haydn". (op.cit., p.41)
} 
O primeiro local a ser alcançado por Griboiédov é a cidade de Tíflis, onde permaneceria por apenas três meses. Continuou a escrever artigos para jornais russos (por exemplo, o artigo de 21 de janeiro de 1819 acerca das atividades perpetradas em sua missão). Além de ser bem sucedido em seus intentos diplomáticos, foi na Pérsia que Gorie ot uma começou a tomar forma.

A trama já fora escrita, em São Petersburgo, pelos idos de 1816. Ele foi trabalhando, delineando, recortando a comédia e acabou por, entre outros arranjos, excluir, segundo Beguitchov, a figura da mulher de Fámussov, uma grande dama dotada de maneirismos sentimentais.

Diz-se que a forma final da trama nasceu de um sonho profético que Griboiédov tivera nesse exílio forçado na Pérsia. Em uma carta datada de 17 de novembro de $1820^{122}$, endereçada a um príncipe - sem identificação no nome, mas, segundo Kelly, possivelmente Chakhovskói -, Griboiédov relembra o sonho. Nele, recebem-no à porta de um baile, uma grande festa. Lá, ele encontra inúmeros rostos familiares. Todos estão felizes em revê-lo, e o príncipe, ao qual a carta é direcionada, questiona-o, fazendo-o prometer que irá escrever e que, dentro de um ano, estará pronto. Alguém, indefinido, aproxima-se e diz: "Лень губит всякий

122 Cf. o ensaio (1904): SCHEGOLIEV, P. E. Piervientsy Russkoi Svobody. Vstupit. Statia I Kommient. A.S. Griboiedov i Diekabristy. I. N. Emielianova. M.: Sovriemiênik, 1987, http://az.lib.ru/s/shegolew_p_e/text_0140.shtml, primeiro acesso em 26/08/2009) 
талант"123. Ao final, descobre-se que esse alguém é Pável Katenin amigo de Griboiédov e, como vimos acima, co-autor da peça Студент (O estudante). A promessa mencionada no sonho, no entanto, levou mais de um ano para ser cumprida, ou melhor, ao todo, quase quatro $\operatorname{anos}^{124}$.

A carta, em seus excertos mais significativos, no original:

Entrei na casa; nela, era noite de festa; eu nunca estive naquela casa antes. $O$ anfitrião e a anfitrião (...) receberam-me na porta. Atravessei o primeiro salão e ainda havia alguns outros. Iluminação em toda a parte; ora apertado em meio às pessoas, ora espaçoso. Deparei-me com muitos rostos, um parecia-se muito com meu tio e outros também me eram conhecidos; aproximei-me até o último aposento, onde havia uma multidão de pessoas; alguns jantavam, outros conversavam; você também estava sentado lá, em um canto, e inclinado a alguém, cochichava a alguém ao seu lado. Extraordinária e agradável sensação, mas não nova, ao passo que, na memória, faíscam em mim, (...) do aposento, você veio ao meu encontro. Primeiro, a palavra: é mesmo você, Aleksandr Serguéievitch? Como está mudado! É impossível reconhecê-lo. Venha comigo; (...) Nos sonhos, as dimensões desfiguram-se; mas tudo isso é um sonho, não se esqueça. (...) Prometa-me que irá escrever. - O que você quer? Quando estará pronto? - Após um ano, sem falta (...) Após um ano, eu juro.(...) sussurraram essas palavras: a preguiça mata qualquer talento... E você se virou para um homem: Veja quem está aqui. Ele levantou a cabeça e suspirou, e um som agudo alcançou meu pescoço... Eu tenho um amigo (...) Katenin! E, então, eu acordei. ${ }^{125}$

$* * * * *$

123 Do russo: A preguiça mata qualquer talento.

${ }^{124}$ Vilguelm Kárlovitch Kiukhelbéker (1797-1846), poeta e amigo de Griboiédov, e que o encontra em Tiflis, afirmou que Горе от ума foi escrito praticamente diante de seus olhos. Ao terminar cada parte, Griboiédov fazia questão de lê-las. (KELLY, Laurence. Diplomacy And Murder In Tehran: Aleksandr Griboyedov And Imperial Russia's Mission To The Shah Of Persia. London: I.B. Tauris Publishers.p. 83.)

${ }^{125}$ Carta Griboiédov a Katenin: Schegoliev, 1987, cit., trecho em tradução nossa. 
Ao retornar para Moscou, após anos de ausência, em março de 1823, Griboiédov entra em um frenético ritmo de bailes, reuniões e piqueniques. É como se, nesse período de retorno, ele quisesse absorver toda a sociedade russa para, assim, delineá-la de outra forma. Quando chegou, a arte fervilhava: nos últimos anos, Púchkin publicara Руслан и Людмила (Ruslan i Liudmila; Ruslan e Liudmila, 1820); e os volumes de Karámzin, История государства Российского (Istoria Gossudarstva Rossiiskovo; História do Estado Russo), foram publicados de 1818 a 1821.

Após associações com Púchkin, Odoiévski e Kiukhelbéker ${ }^{126}$, a próxima empreitada no terreno do teatro foi o texto para o libretto de um vaudeville de Verstovski, Кто брат, кто сестра, или обман за обманом (Kto brat, kto siestra, ili obman za obmanom, 1823)127. Como todas as peças de vaudeville, a trama é simples, em um misto de ópera-cômica e comédia. Trata-se das diferenças de personalidade entre dois irmãos, um mais velho e outro mais novo, bem como suas investidas no amor. Sem qualquer chama artística, o vaudeville só é interessante pelo fato de que, na mesma época, começaram a sair os primeiros manuscritos "prontos" de Gorie ot uma ${ }^{128}$.

As primeiras leituras de Gorie ot uma - ao todo, doze -, nas quais estavam presentes Krylov, Khmielnitski, Chakhovskói, tornaram-se momentos de intensa excitação e delírio. A comédia, já

\footnotetext{
126 Ele publicou seu poema Давид (David), junto destes autores, na obra de Kiukhelbéker - Memento mori.

127 O trabalho teve a colaboração de Viazemski.

${ }^{128}$ Os primeiros manuscritos "prontos" datam de 1823 e 1824.
} 
nesses primeiros instantes, ganhava o status de obra-prima genial. Assim, o texto foi passando de mão e mão, e, em pouco tempo, mesmo censurada, a comédia já era conhecida de todos os literatos de São Petersburgo e Moscou. No entanto, devido à censura, a peça não pôde ser encenada, em vida do autor, tendo-o sido apenas nos anos sessenta - ou seja, quase quarenta anos após sua composição. Uma primeira publicação da obra, ainda incompleta, apareceu em 1833.

Um próximo salto, sem mais detalhes acerca da peça Gorie ot uma - trabalho a ser perpetrado mais adiante -, passemos a outros acontecimentos significantes da curta vida de Griboiédov. Importante para a biografia do autor e, principalmente, para a história da Rússia: o Movimento Dezembrista.

Em um artigo recente, que busca algumas informações novas acerca de Griboiédov, instala-se um dos mistérios de sua biografia, importantes ao estudo da história, em relação ao período inicial do Movimento Dezembrista: o relacionamento do dramaturgo com os membros da Союз Благоденствия (Soiuz Blagodienstvia, União da Prosperidade).

Há muitos pesquisadores que tentaram, de diversas formas, implicar Griboiédov de maneira direta na insurreição, colocando-o como participante ativo da mesma. Essa vertente de pensamento teve sua força redobrada no trabalho da estudiosa soviética 
Niechkina ${ }^{129}$. Em verdade, é possível que Griboiédov estivesse envolvido de alguma forma, mesmo que indireta, pois grande parte de seus amigos, da época de então e no passado, tiveram suas atividades marcadas no movimento.

Ele era próximo a V.F. Raiévski (cuja participação e importância foram primordiais e cruciais para o movimento), a A.I. Iakubóvitch, P.G. Kakhóvski, F.F. Vadkovski e N. A Zagoriétski, todos dezembristas. Era amigo de I.D. Tcherbatov e Piotr Tchaadaiev. Enfim, fazia parte de um meio em que a agitação e inconformismo viviam irmanados. Talvez fosse muito difícil, na época em que a literatura e a política encontravam-se aglutinadas, deparar-se com alguém, principalmente um artista ativo, que estivesse distante da realidade prática das ideologias.

O próprio Púchkin estava nesse meio e, como Griboiédov, conhecia grande parte dos implicados. O importante aqui é assomar a força insurrecta que pode advir das personagens de Gorie ot uma, provenientes, essencialmente, de Tchátski.

As raízes, para o Movimento Dezembrista, aparecem nas sociedades secretas e lojas maçônicas, surgidas ainda no início do século XIX. A União da Prosperidade encontra embriões de sua criação em 1816.

\footnotetext{
${ }^{129}$ A historiadora Niechkina, especialista na insurreição dezembrista, escreveu uma obra colossal sobre Griboiédov e o dezembrismo, tentando, assim, provar que ele era um revolucionário, e a peça, uma amostra panfletária da revolução. Ela escreveu: Дивижение декабристов (Divijenie diekabristov, $O$ movimento dos dezembristas) е Грибоедов и декабристы (Griboiedov i diekabristy, Griboiédov e os dezembristas).
} 
Tendo em sua formação os oficiais da guarda, a Sociedade idealizava reformas sociais, provenientes da instrução do povo para, assim, alcançarem maior liberdade política. É dessa Sociedade que nascem a vertente Setentrional e a vertente do Sul. Na Setentrional, a sociedade é chefiada por Nikita Muravióv, o príncipe Trubiétskoi e o poeta Ryléiev ${ }^{130}$. No Sul, de tendência mais radical, a sociedade é chefiada pelo coronel Pestel, que preconizava a transformação da Rússia em uma República Democrática fortemente centralizada. ${ }^{131}$

Em busca de uma visão que acompanhasse essas mudanças, a Maçonaria surgiu como uma tendência liberal e atraiu a muitos deles. Outros a evitavam por conta do forte misticismo. As sociedades secretas e as lojas maçônicas coexistiram por alguns anos, principalmente entre 1810 e 1820 . No entanto, tanto uma como outra foi proibida, em $1822 .{ }^{132}$

Griboiédov, como muitos de seus colegas, também frequentara uma loja maçônica, a Les amis reunis, junto a Pestel,

\footnotetext{
130 Ryléiev, Kondráti Fiódorovitch (1795-1826) - poeta russo, que participou da campanha dos russos contra Napoleão na Europa. Em 1818, "regressou a São Petersburgo, aproximando-se dos escritores mais progressistas da capital, sobretudo Kiukhelbéker e Glinka. Em 1823, ingressou na organização secreta revolucionária "Sociedade Setentrional", principal foco instigador da Revolta Dezembrista.(...) Foi um dos dirigentes da Revolta na praça do Senado, em 14 de dezembro de 1825. Detido, foi encarcerado na fortaleza de S. Pedro e S. Paulo e foi enforcado em 13 de julho de 1826. (Índice de Notas e Referências, 2004, cit., p.232)

${ }^{131}$ MILIUKOV, Paul. Histoire De Russie, Tome Ii: Les Successeurs De Pierre Le Grand, De L'autocracie Appuyee Sur La Noblesse A L'autocracie Bureaucratique. Paris: Librairie Ernest Leroux, 1932. p. 685-86.

132 Em Primeiro de Agosto de 1822, todas as sociedades secretas e todas as lojas maçônicas foram proibidas. (MAZOUR, Anatole G. The First Russian Revolution, 1825: The Decembrist Movement. California: University Of California Press, 1964. p.51.)
} 
Muraviov-Apostol e Dolgorukov ${ }^{133}$. Sendo assim, é quase impossível imaginar que Griboiédov não estivesse familiarizado com suas visões. ${ }^{134}$

E foi mediante esses embriões de liberdade, que pululavam por entre "as cabeças fervilhantes" - relembradas por Repietilov, em Gorie ot uma -, que, em dezembro de 1825, o Movimento teve lugar.

Em poucas palavras, o Movimento Dezembrista representa, segundo Mazour, um fenômeno complexo enraizado em fatores econômicos, políticos e sociais. As causas das insatisfações firmavamse já nos idos do século XVIII, e podem ser percebidas na situação drástica em que viviam os servos e já na rebelião de Pugatchóv. Com a ascensão ao trono, por parte de Aleksandr I, a esperança por reformas aumentou. No entanto, passado algum tempo, o camponês ainda permanecia em condição precária, a instituição da servidão fortemente consolidada, e a monarquia intensamente despótica ${ }^{135}$.

A Sociedade Dezembrista foi se formando mediante essas condições e, acima de tudo, ansiava pela abolição dos servos, pela reforma constitucional e pelo afrouxamento do poder autocrático, com a criação de uma espécie de governo representativo. Visto aos

\footnotetext{
133 Todos eles, futuros líderes do movimento Dezembrista.

134 "De 1820 em diante, vários grupos políticos começaram a organizar sociedades secretas com objetivos revolucionários, similares àqueles da Europa Ocidental. Esses desenvolvimentos abriram caminho diretamente para a catástrofe de 14 de de 1825". (MAZOUR, Anatole G. The First Russian Revolution, 1825: The Decembrist Movement. California: University Of California Press, 1964. p.63., trecho em tradução nossa)

${ }^{135}$ Ibidem, p.262
} 
olhos da atualidade, os dezembristas podem ser considerados conservadores, mas, à época, eram radicais.

E, sendo assim, após a morte de Aleksandr I - a Rússia tendo já Nikolai I como czar -, em 14 de dezembro de 1825, centenas desses membros reformistas das guardas imperiais, aglutinados na chamada sociedade dezembrista, reuniram-se na Praça do Senado, em São Petersburgo, em frente à estátua de Pedro, o Grande. Fizeram, então, uma grande manifestação em prol das referidas reformas. A emancipação dos servos e o federalismo na forma de governo para a Polônia, Ucrânia e Lituânia, eram também pauta. Para sabermos, de certa forma, como funcionavam suas requisições, temos um manifesto, escrito por Trubietskói, e que continha: O manifesto do Senado deve proclamar: a abolição do governo como está; o estabelecimento de um governo provisório até que um permanente seja decidido pelos representantes; liberdade de imprensa, bem como a abolição da censura; tolerância religiosa a todas as crenças; abolição do direito de propriedade sobre um homem; igualdade de todas as classes perante a lei (...); pronunciamento dos direitos de todos os cidadãos a ocuparem-se no que desejarem (...); abolição do monopólio de sal e álcool; entre outros. ${ }^{136}$

136 Manifesto, escrito pelo "Ditador" Trubetskoi, na noite de 14 de dezembro de 1825. (MAZOUR, Anatole G. The First Russian Revolution, 1825: The Decembrist Movement. California: University Of California Press, 1964. p.283.) 
O levante, no entanto, resultou em fracasso. Os membros foram todos punidos, passando por julgamentos públicos, execuções, prisões em massa e exílio na Sibéria. Entre os vários suspeitos, cúmplices e álibis interrogados pela polícia imperial, estava Aleksandr Griboiédov.

Já no início do próximo ano, em 11 de Fevereiro de 1826, ele foi detido por alguns dias e, ao final, decidiu-se a mandar uma carta ao czar pedindo clemência e absolvição de tamanha injusta suspeita.

Griboiédov escapou das suspeitas de envolvimento no levante por declarar-se inocente e ignorante frente à formação de uma sociedade secreta ${ }^{137}$. No entanto, ele compartilhava de alguns dos pensamentos e visões de seus conhecidos dezembristas, que buscavam a transformação da Rússia. "O início e a raiz da sociedade deve ser procurada no espírito do tempo e na situação em que nós nos encontramos", dizia Kakhóvski, "esteja à vontade para dizer se em milhares de jovens não haverá pelo menos uma centena deles, resplandecendo paixão pela liberdade"138. No entanto, ainda que partilhasse, politicamente, das mesmas ideias, Griboiédov, ao mesmo tempo, não satisfazia os requisitos apresentados pelas normas cotidianas de comportamento, conforme o ponto de vista de quem fazia parte do círculo. Zavalischin dizia que, visto como um homem, "foi trazido de uma vida militar (..) à vida em Petersburgo", ou seja,

\footnotetext{
137 Uma das acusações a Griboiédov encontra-se na própria peça: o uso da palavra Carbonari (ver comentário na presente tradução da obra).

${ }^{138}$ Schegoliev, 1987, cit., trecho em tradução nossa.
} 
um mundo de aventuras e loucuras amorosas encontrava repúdio aos olhos de Kakhóvski, que era um livre-pensador, profundo e consciente.

Ao relembrar os poetas Griboiédov e Púchkin, Zavalischin diz que "para a juventude da época, eles eram pessoas muito diferentes do que a próxima geração, que os veria pelo prisma com um esclarecimento maior de seus trabalhos e ações e são, mais frequentemente, julgados com base nessa visão posterior"139.

No depoimento de Ryléiev, após a desastrosa Revolta, o poeta relembra a presença de Griboiédov junto à Sociedade: "Com Griboiédov, tive alguma conversa mais geral acerca da situação da Rússia e insinuei sobre a existência da Sociedade, que almejava transformar o modo de governo na Rússia e introduzir uma monarquia constitucional; mas ele acreditava que a Rússia não estava pronta ainda e que havia opiniões relutantes sobre 0 assunto" $^{140}$.

Sendo assim, por mais que houvesse a proximidade junto aos dezembristas, Griboiédov, provavelmente, teve tênue relação direta com os eventos que se sucederam em dezembro de 1825, no início do governo de Nicolau I. No entanto, a simples possibilidade de uma participação na primeira insurgência russa de destaque potencializa a figura mítica de Griboiédov e de sua peça Gorie ot uma - drama

\footnotetext{
139 Schegoliev, 1987, cit.

${ }^{140}$ Schegoliev, 1987, op.cit.
} 
pincelado por pensamentos coadunados com a emergência de transformações na Rússia.

$* * * * * * *$

Tendo-se livrado de uma punição mais severa, como aconteceu aos seus colegas, Griboiédov logo partiu para a Pérsia, pois que uma guerra estava sendo deflagrada. Ele conseguiu certo sucesso nas suas empreitadas diplomáticas, especialmente durante os próximos dois anos, até 1828. Ele retorna para a Rússia, por um tempo, mas, em junho do mesmo ano, deixa o país, para sempre.

Em 1829, recém-casado com a princesa georgiana Nina Chavchavadze, Aleksandr Griboiédov é assassinado, junto a toda sua embaixada, por uma massa persa, em uma época em que ele sugerira termos para um tratado de paz, na segunda guerra RussoPersa.

Tornou-se famosa as palavras de Aleksandr Púchkin que, a retornar de uma viagem do Cáucaso - onde pretendia encontrar-se com o irmão -, depara-se, no caminho, com uma carroça descendo a estrada. Ao perguntar aos homens que a acompanhavam, Púchkin soube o que a carroça levava: o corpo de Griboiédov. ${ }^{141}$

141 Púchkin escreveu: "Eu não acreditava que iria encontrar nosso Griboiédov novamente! Eu me separei dele no ano passado, em Petersburgo, antes de sua partida para a Pérsia. Ele estava triste, e tinha estranhos pressentimentos. Eu 
A vida de Griboiédov, mesmo curta, assemelhou-se ao destino das lendas. Ainda que possuísse inúmeras ideias para novos trabalhos artísticos, ele não pôde realizá-los e, sendo assim, nunca poderemos saber se as obras subsequentes seriam geniais tais como o é a comédia Gorie ot uma. Fica-nos o mistério, o crivo da estética de palavras postas como símbolos de uma época, em provérbios lapidados, em tempos de criação e formação de uma língua literária rica, inovadora.

Aleksandr Griboiédov, tal como Tchátski, partiu sem olhar para trás, a buscar, no mundo, um cantinho para os sentimentos. Os sentimentos todos, ou seja, a arte, em sua intenção e difusão máxima. Ele encontrou seu posto eterno e, novamente, relembrando as palavras de Gontcharov, sua voz pode, em Gorie ot uma - não importa o tempo que passar -, caminhar, vívida e frondosa, por entre o túmulo dos velhos e o berço dos novos.

pensei em reanimá-lo; ele me disse: 'Vous ne connaissez pas ces gens-là: vous verrez qu'il faudra jouer des couteaux'. Ele confirmou que o sangue derramado resultaria na morte do Xá e a divisão dos feudos entre seus sete filhos. Mas o velho Xá está ainda vivo, e, ainda assim, a profecia de Griboiédov tornou-se verdade". (KELLY, Laurence. Diplomacy And Murder In Tehran: Aleksandr Griboyedov And Imperial Russia's Mission To The Shah Of Persia. London: I.B. Tauris Publishers. p.1., trecho em tradução nossa) 


\section{A estrada}

Nos ensaios e prefácios à peça Gorie ot uma, a principal preocupação dos pesquisadores é exaltar a linguagem, o ritmo da palavra, a música em versos que Griboiédov ofertou, como modelo único a persistir no tempo, à posteridade. Se eles não sucumbem às tentativas em inserir a comédia como panfleto revolucionário, tendem a rotular o enredo como tipicamente neoclássico, tratando-se por vezes apenas de uma comédia de costumes, e com a ação diminuta, em uma sequência de estereótipos sem qualquer profundidade nas personagens. Há muitos que, diante do gigante Molière, remetem o conteúdo da peça a uma simples transposição de Le misanthrope ao universo russo ${ }^{142}$, ofertando-Ihe apenas uma cor local. Há outros que preferem retirá-la do panteão das obras sagradas do Teatro Russo, colocando-a apenas como parte de um pré-momento grandioso da literatura, que prefacia Púchkin, Gógol e Liérmontov.

Sim, para a lírica e para o enriquecimento da língua literária russa, Púchkin e Liérmontov são inigualáveis. Um leitor, apenas alfabetizado no cirílico, e ainda que não compreenda as palavras, chega a ficar embevecido com a musicalidade que os versos magistrais desses poetas nos proporcional.

Para Gontcharov, Púchkin é nome único dentre o grupo, "é enorme, frutífero, forte, rico. Ele é, para a arte russa, o que

142 No prefácio da tradução holandesa da peça, o tradutor afirma que Gorie ot uma é uma variante de Le misanthrope, de Molière, com alguma cor local - uma sociedade pós-invasão napoleônica. 
Lomonóssov é para a educação em geral. Mas, apesar do Gênio de Púchkin, o melhor de seus heróis, dos heróis de seu tempo, já desapareceu, permanecendo no passado". O romancista continua seu pensamento ao acreditar que, apesar da importância do herói de Púchkin, e também o Pietchórin, de Liértmontov, ambos não passam de estátuas em seus túmulos. Não são mais do que memória literária. No entanto, Gorie ot uma e seu Tchástki chegaram primeiro, passando incólume pela época de Gógol e sobrevivendo a muitas eras sem perder qualquer traço de sua vitalidade.

Para Grigóriev, cada verso de Griboiedov é pincelado de sarcasmo, que escapa da alma do artista no calor da ira. Ele soube levar poesia à linguagem cotidiana da sociedade russa, "mesmo que não tenha lhe custado o menor trabalho, é ainda grande crédito para suas mãos".

Para o teatro, Gógol é a grande subversão do modelo clássico. Após quase dez anos do furor inicial da comédia de Griboiédov, Gógol surge com $O$ inspetor geral (1836). Tudo o que vimos no começo do presente trabalho, nas palavras de Boileau, desaparece em Gógol: os "gracejos nobres", "o estilo doce", a voz "do agradável autor" não mais existem. Há muitos anos, a influência, do vaudeville ${ }^{143}$ e da

\footnotetext{
143 Sobre Gógol e o vaudeville - "Quem diria que haveria nos palcos russos, além de vaudevilles traduzidos, algumas produções originais? Um vaudeville russo! É mesmo muito estranho. Estranho porque este brinquedo ligeiro e incolor só poderia ter nascido na França, uma nação, cuja natureza não apresenta uma fisionomia impassível e profunda. Mas quando um russo, de natureza ainda severa e pesada se vê obrigado a transformar-se em um petit-maître, tenho sempre a impressão de ver um dos nossos comerciantes, corpulento e espero, com sua longa barba, que não calça outra coisa a não ser botas pesadas, portando um minúsculo sapato e
} 
ópera-cômica, buscava por afrouxar tão estreitas estruturas. Mas, em O inspetor geral, nosso riso se confunde, perde-se e, como uma bofetada, o prefeito nos questiona: "Do que estão rindo? Estão rindo de si mesmos!" Uma sombra estranha perpassa as cenas e convidanos a um universo diabólico, obscuro, mas nitidamente cômico, em uma apoteose do negativo. Para André Siniavski, em meio ao panteão das grandes comédias russas da primeira metade do século XIX - as quais se destacam Недоролсь (Niedorols'), de Denis Fonvízin, e Gorie ot uma - O inspetor geral figura-se como a obra mais negativa. Ele afirma: "No desenvolvimento da comédia russa, que vai de Fonvízin a Gógol, passando por Griboiédov, observamos uma amenização inexorável da virtude e um progresso fulgurante do mal que, em Gógol alcança a amplitude de uma catástrofe social". ${ }^{144}$

Não há apenas uma única personagem virulenta (todos o são), ou quiçá um matiz que permita a coloração reluzente em um quadro obscuro, possibilitando assim a iluminação, a salvação. Em $O$ inspetor geral, não há o menor resquício de brilho e tudo está infeccionado, "como se toda a Rússia não recebesse mais o menor raio de luz ou o menor vestígio da virtude". E a comédia, longe da obediência clássica, encanta pela subversão. Há comicidade em tudo: nas

meias à jour, embora no outro pé ainda esteja a sua bota, e se põe desse jeito na primeira fila de uma quadrilha francesa. (Cf. CAVALIERE, Arlete. Teatro Russo: Percurso Para Um Estudo Da Paródia E Do Grotesco. São Paulo: Humanitas, 2009. p. 139.)

144 SINIÁVSKI, A. "Chapitre Ii, Deux Tours De <<Revizor>> Avec La Clé D'argent". In: Dans L'ombre De Gogol. Traduit Du Russe Par Georges Nivat. Paris; Éditions Du Seuil. p.74. 
formas, nos movimentos, nas situações, nas palavras, no caráter. A sociedade refletida está imersa em uma espécie de automatismo e que Henri Bérgson nos faria lembrar: "as atitudes, os gestos e os movimentos do corpo humano são risíveis na exata medida em que esse corpo nos faz pensar numa simples mecânica" ${ }^{145}$. Esse corpo, ou seja, essa sociedade, tende a exaltar-se em sua pantomima, em seu exagero, em sua deformação que testa todas as possibilidades até transformar-se em pétreo diabolismo. Uma comicidade proporcionada pelo ápice das trevas.

É natural que, portando um emblema do universo dos contrários, $O$ inspetor geral seja relembrado como a grande comédia russa do século XIX, pois, até hoje, parece-nos atual. Frente a tal monstro da dramaturgia, o enredo de Griboiédov parece arrefecer e, quando traduzido para outros idiomas, perde ainda mais, pois, até hoje, nenhuma tradução chegou, mesmo ao longe, da grandiosidade das palavras ${ }^{146}$.

No entanto, mesmo com a obediência a, aparentemente, todas as regras clássicas de unidade, Gorie ot uma segue a trajetória, de modo concomitante, de duas tramas, que estão imbricadas e que são desembaralhadas ao final, promovendo, assim, um alargamento da unidade da ação. Veremos adiante que, entre ambas as tramas, não

\footnotetext{
145 BÉRGSON, Henri. O Riso: Ensaio Sobre A Significação Da Comicidade. Tradução De Ivone Castilho Benedetti. São Paulo: Martins Fontes, 2004

146 Karlinsky nos fala apenas da tradução para o polonês. No entanto, sendo o polonês um idioma originário do ramo eslavo, tem-se aí uma explicação plausível para sua aproximação (Karlinsky, 1985, cit.).
} 
há uma que seja superior, sobressalente, principal. Na trilha aparente, muito recorrente nas comédias de até então, há o desencontro amoroso, o quiproquó que dele pode advir. Mas por trás, rasgando os versos, há também outro desencontro, mais visceral, e que não pode ser resolvido. Esse é o desencontro de um homem inteligente em meio a um bando de tolos.

Para demonstrarmos como Gorie ot uma não respeita as regras clássicas com retidão - e mais, constrói uma trama muito mais complexa do que uma comédia neoclássica padrão -, atravessaremos o caminho de sua história, observando que todos os conflitos se sustentam, nas duas tramas, com igual força, como se coexistissem duas peças em uma só. Para tal, deflagraremos o universo de seu conteúdo.

Como já dissemos no início, Gorie ot uma foi escrito em versos iâmbicos livres, em quatro atos. Um verdadeiro recorte social da época, a comédia fez rir, chocou, esteve censurada por anos e, quando foi encenada pela primeira vez, já era conhecida de todo o público. A fábula, em poucas palavras, conta sobre um homem que retorna do estrangeiro, após três anos de ausência, e não encontra nada que o faça querer ficar. Seu amor está perdido. E Moscou está perdida.

O dia amanhece. Liza, a criada, está sentada em uma cadeira, dormitando. Ao escorregar, ela desperta e percebe que a noite passou muito rápido. Ela já anuncia sua tarefa: a noite toda em claro 
para vigiar sua senhora e o amigo. Sófia, a senhora, está com Moltchálin, a paixão da atualidade. Antes, ela fora apaixonada por Tchástki, seu amigo de infância, mas, como troca de amores como de sapatos, ela sente-se, agora, amando como nunca. Logo aparece Fámussov, pai de Sófia e dono da casa. Atrás do barulho que vem do aposento da filha - o sino do relógio -, ele encontra todos juntos: Liza, tentando salvar sua senhora do flagra do pai; e Sófia e Moltchálin, fingindo, ao máximo, o encontro perpetrado às escondidas.

Nas próximas cenas, conhecemos o espírito de cada um: Liza, a esperta criada, a soubrette das comédias neoclássicas ${ }^{147}$ - suas palavras são crivadas por uma rapidez, certa astúcia quase irreal nas criadas russas da época; Fámussov, de caráter inflado, repleto de um palavreado que contraria suas ações - como no momento em que flerta com Liza e, em pouco tempo, afirma ter uma "conduta de monge"; Sófia, a figura sentimental, a amante dos romances franceses povoando suas falas de termos românticos, tais como a descrição do sonho e as manifestações de infelicidade ao afastar-se do amado; Moltchálin, o secretário de Fámussov, servil, mudo e que, em pouco, revelar-se-á o contrário.

Contra as expectativas de todos, aparece Tchátski, velho conhecido da família e antigo amor de Sófia. Eles eram amigos de

147 Semelhante às soubrettes (criadas da comédia neoclássica) de Marivaux, Gresset; e, principalmente no caso russo, a Sácha de Урок кокеткам, или Липецкие воды (Urok koketkam, ili Lipietskie Vody). 
infância e, após três anos de ausência, Tchátski parece ansioso em revê-la. Ante a surpresa de Tchástki, Sófia mostra-se fria e distante, aparenta evitá-lo de alguma forma, cortando-o com falas bruscas e irônicas. Ele, apaixonado e desesperado por revelar seu amor, levará algum tempo para perceber que sua amada não está nem um pouco interessada nele, mas sim, por Moltchálin.

Como o próprio nome diz - do verbo "молчать", calar, silenciar; do adjetivo "молчаливый", calado, silencioso -, Moltchálin representa a sociedade russa arcaica que não diz nada de próprio e verdadeiro, preferindo calar-se frente às mudanças, ao progresso. Ele é o servilismo, a automatização do indivíduo como apenas engrenagem de uma máquina superior, tirana. A todo o momento, ele se revela em suas falas, pontuadas por diversos "_c" (abreviação da palavra "сударь", meu senhor), partícula arcaica colocada junto às palavras para denotar educação e deferência ("Да-c"). Ele parece ser despido de pensamentos e ideias próprias e até concorda em não mantê-las. Ele é o oposto de Tchátski, um homem apaixonado, instintivo e racional - ora fala com o coração para, logo após, e com angústia, apossar-se da razão. Por isso é tão estranha a paixão de Sófia por Moltchálin. Aos poucos, o espectador ou leitor da peça passa a desgostá-la, a desprezá-la.

Grigoriev ${ }^{148}$ diz: "Inconscientemente, surge a questão: será que a insignificante Sófia vale a pena? Talvez sim, talvez não. Há dois

${ }^{148}$ Apolon Aleksandrovitch Grigoriev (1822-1864): poeta e crítico literário russo. 
tipos de mulheres. Algumas têm a capacidade de se sacrificar, até mesmo vistas como cães. Na melhor delas, essa habilidade torna-se a esfera de uma educação mais elevada, ou seja, a habilidade de anexar os ideais de beatitude e verdade aos menos favorecidos transforma-se em pura escravidão ao objeto amado. As melhores delas podem ser muito enérgicas. É a própria natureza que fornece tais mulheres enérgicas, frequentemente belas. Em contraste, a outra tem toda a graça, (...) a flexibilidade de um gato (...), mais sábia e dotada de demandas mais complexas do que aquelas características à natureza da primeira"149. Aqui Grigóriev faz um interessante paralelo, colocando o segundo tipo como pertencente a mulheres como Sófia e Desdêmona ${ }^{150}$. O crítico reforça: não quer fazer, com tal referência, um paralelo paradoxal, posto que uma pertence à comédia e a outra à tragédia. No entanto, ambas pertencem ao mesmo tipo, pois apesar da pureza de Desdêmona, a frivolidade permanece. O paralelo é interessante, mas, se pensarmos em Sófia, a comédia torna-se tragédia, posto que sua frivolidade sufoca sua pureza, remetendo, na superfície, a uma pureza própria da infância; no entanto, sua pureza não é infantil, mas sim, frivolidade consciente e representativa do entorno. Ela troca de amores, como troca de sapatos. Grigoriev continua: "as pessoas como Tchátski frequentemente gostam de mulheres insignificantes e triviais como Sófia. Poder-se-ia dizer que a

\footnotetext{
${ }^{149}$ GRIGORIEV, A.A. Po povodu novovo izdaniia vieschi, "Gorie ot uma". Spb. 1862. http://az.lib.ru/g/grigorxew_a_a/text_0330.shtml, acesso em 25/08/2009, trecho em tradução nossa.

${ }^{150}$ Desdêmona, personagem feminina da obra Otelo, de William Shakespeare.
} 
maioria ama. Eis aí o paradoxo. Ocasionalmente são encontrados com mulheres justas, completamente capazes de entendê-los, de partilhar suas aspirações $(\ldots)$ ". "Ou seja, homens como Tchátski são atraídos por algo inevitável e fatal em suas vidas, que, aos que conseguem escapar, seguem em prol de mulheres honestas e valorosas"151. Para Tyniánov, Sófia representa um mundo, sendo assim, a visão de Grigoriev pode alçar um panorama mais amplo, pois Tchátski é atraído, por alguma força indefinida, a algo inevitável e fatal, inerente a cada conflito perpassado na comédia. Ele chama e repele cada interlocutor, como se, constantemente, neles, reencontrasse um pedaço de Sófia e de Moscou - a paixão ardente que faz retornar e a repulsa, que faz fugir "a um cantinho para os sentimentos ofendidos". Tchátski está horrorizado pela escolha de sua amada. Decide culpar a sociedade moscovita por ter transformado Sófia em uma criatura cega e frívola. Nesse meio tempo, aparece-lhe o coronel Skalozúb (que de tão exemplar, segundo Fámussov, será general), homem de estreitas ideias, que não consegue absorver qualquer informação alheia ao serviço militar.

O primeiro e o segundo atos são preparações para o clímax, atingido no terceiro e quarto atos: a cena do baile, onde estão reunidas as figuras-modelo da sociedade russa. É nesse ambiente que Tchátski se revela por inteiro, sendo chamado de louco. Em um fio de intrigas e mexericos que funciona dramaticamente, o boato sai

${ }^{151}$ Grigoriev, 1862, cit., trecho em tradução nossa. 
da boca de Sófia para chegar aos ouvidos de todos como verdade incontestável. A mentira corrente passa pelas estranhas personagens S.N. e S.D ${ }^{152}$ e ganha o salão todo, subvertendo o estado de Tchátski para uma loucura que, segundo o indicado pelo julgamento de todos, deve ser tratada e medicada em sanatório.

Ao final, Sófia descobre ter sido enganada por Moltchálin que não a ama, mas sim à criada particular, Liza. Os verdadeiros escrúpulos de Moltchálin são revelados em sua conversa com Liza que, por sua vez, ama Pietrúchka ${ }^{153}$, o criado de Fámussov. Nas cenas cruciais que acercam o final, Tchátski se sente redimido, pois mesmo não tendo sua amada, não a terá também Moltchálin. Escandalizado pela descoberta do amor de sua filha por um empregado, Fámussov mostra, no minuto final, todo o sentido impregnado naquela sociedade em que se vive para as aparências: "Ah! Meu Deus! E a Princesa,/ Que dirá Maria Alekseievna?". Esses versos, tornados um provérbio, fecham a obra.

Há paralelos entre Alceste, de Le misanthrope de Molière, e Tchátski. Na tradução exposta no presente trabalho, traçamos alguns paralelos de falas de Alceste às de Tchátski. No entanto, Gorie ot uma não é uma transposição da comédia francesa, pois Sófia não é

152 Provém de Господин Д. (Gospodin D.) е Господин H (Gospodin N.) - Senhor D. e Senhor N.

153 Pietrúchka quase não aparece na peça, como muitas personagens apenas aludidas no texto. Sua figura é mencionada, principalmente, no Ato II. É ele quem não deve ler como um sacristão ("Leia: Não, não! Não como um sacristão!") e também é ele o irresistível amor de Liza. 
Célimene - muito mais ardilosa, repleta de astúcia; e, seguramente, Tchátski não é Alceste - muito mais sério e intolerável.

Os modelos para a criação das personagens, além do que a realidade já ofertava, não estão, diretamente, no modelo francês, mas sim, nas próprias comédias russas antecessoras à obra de Griboiédov, ou seja, aquelas escritas por seus amigos, Chakhovskói e Khmielnitski - Урок кокеткам, или Липецкие воды (Urok koketkam, ili Lipietski vody) е Говорун (Govorun), respectivamente.

Há antecedentes para a criação da história já nos idos de 1812, mas, segundo Karlinsky, Griboiédov apenas começou a desenvolver a comédia após assistir às encenações das obras citadas acima. Em uma das primeiras versões, descartada depois, a peça chamava-se Горе уму (Gorie umu), ou seja, algo como Uma desgraça para a inteligência. Ele continuou transformando as versões até 1828, próximo de sua última viagem para a Pérsia. De qualquer forma, se a peça adquiriu qualquer formato externo, este proveio da própria Rússia e não da França. Para provar tal ideia, Karlinsky nos oferece esse trecho, a fábula de uma comédia escrita na primeira metade do século XIX:

Inicia-se com um nobre russo, de grande integridade moral e princípios intransigentes, chegando, de madrugada, após um período em viagem, a um lugar onde há algumas pessoas que ele deixara há um tempo. Entre eles, há uma jovem mulher com um pensamento independente o qual o viajante esperava encontrar um amigo e aliado. Mas suas intenções demonstram ser um mal entendido e a maior parte da peça é levada com um duelo moral entre essas duas personagens. Após algumas cenas em grupo, que exibe 
uma lista de personagens menores caracterizados satiricamente, há uma confrontação à noite, na qual a jovem mulher expõe o erro de suas ações. ${ }^{154}$

Ao lermos o excerto acima, estamos quase certos de que se trata de um delineamento da fábula de Gorie ot uma. No entanto, trata-se de Урок кокеткам, или Липецкие воды (Urok koketkam, ili Lipietski vody), de 1815, o primeiro sucesso de Chakhovskói ${ }^{155}$ e uma das grandes comédias da época. Certamente, Karlinsky nos prega uma peça. A moça que aparece na fábula não é a mesma por quem o jovem, recém-chegado, está apaixonado. Ela é a condessa Lelieva; ele é Pronski. As particularidades da trama são, nos detalhes, distintas. Mas o caminho seguido por Pronski parece ser o mesmo de Tchátski, pois ambos amam e não são correspondidos e, da mesma forma, encontram um mundo o qual não podem dominar.

Além de outras semelhanças circunstanciais, tais como as soubrettes Liza/Sacha, há, em Gorie ot uma, versos quase idênticos ${ }^{156}$. Não podemos, no entanto, sequer comparar, em termos de qualidade artística, uma peça à outra. Acima de tudo, o mais interessante é atentar-se para o fato de que nem sempre os autores russos buscavam o exemplo direto do panteão francês, inglês ou alemão. O próprio meio - repleto de férteis dramaturgos, produzindo

154 KARLISNKY, Simon. Russian Drama: From Its Beginning To The Age of Púchkin. Califórnia: University Of Carolina Press, 1985. p. 288, trecho em tradução nossa.

155 Leonid Grossman, em seu estudo sobre Púchkin, também afirmara encontrar trechos, em Не любо - не слушай, а лгать не мешай, que podem encontram ecos em Griboiédov. (ibidem, p.297)

${ }_{156}$ Ver os versos similares mencionados, nas notas da própria tradução apresentada no presente estudo. 
mais e mais -, proporciona o alargamento de possibilidades até que se perca a origem como um todo.

Há também, como falamos acima, o paralelo entre a comédia de Griboiédov e a de Khmielnitski, Говорун (Govorun). A peça começa justamente com uma senhora e sua criada, discursando sobre dois pretendentes. E ainda mais: o conde Zvonóv, que não consegue falar sem zombar, sem ironizar, como em Khmelnitski, é um possível paralelo a Tchátski.

No entanto, o Tchátski de Griboiédov é uma figura quase enigmática e sem precedentes. Não é como Alceste, Prónski, Zvonóv. Como nos diz Gontchárov, em Мильион терзаний (Mil'ion Tierzanii, Um milhão de tormentos,1870), Tchátski é o protótipo da época, como uma figura literária tomada diretamente do levante dezembrista.

Para uma minuciosa aproximação de Tchátski, é necessário compreender sua época. O levante dezembrista foi uma das primeiras centelhas da revolução na Rússia. Como já vimos acima, perpetrado por um grupo de indivíduos discípulos de teorias liberais e ocidentalistas, o movimento fez acontecer no meio literário, influenciando também a Púchkin. Era um universo já agitado pela força idealista da mudança. E é de idealismo que vive Tchátski.

Segundo Grigóriev, Tchátski, afora os valores heróicos, tem maior significância histórica. Ele, como muitos críticos, relembra que Tchátski é um produto do primeiro quarto do século XIX, filho e 
herdeiro direto de Novikov e Radischev, memória eterna de 1812. Ele acredita piamente em si e, mediante uma força irrefletida, entregase, como se estivesse pronto a morrer na colisão com o entorno; entorno com o qual luta, mas que fracassa na trajetória de compreendê-lo, levando-o mais a sério do que deveria ${ }^{157}$.

Tyniánov aponta uma forte semelhança entre a vida de Tchaadaiev e Tcháski. Semelhança essa marcada já na raiz do nome "Tchad". Mas a semelhança não para por aí. O pensamento acerca da servidão, tanto de Griboiédov quanto de Tchaadaiev, encontrava-se em comum universo e também o pensamento acerca da significância da personalidade privada, que se mostrou refletida em Tchátski, principalmente a influência altamente incompleta em negócios de estado, de sua autoridade e relacionamentos com figuras importantes do governo, tais como o comandante Vassiltchikov. Isso encontra espelho na cena entre Tchátski e Moltchálin (cena em que Moltchálin se refere às fofocas que foram feitas acerca da relação e rompimento de Tchátski com um ministro, em São Petersburgo, ATO III $)^{158}$.

Para reafirmar essa relação, relembremos de Puchkin, que diz, em carta a Viazemski: "E Griboiédov? Me disseram que ele escreveu uma comédia sobre Tchaadaiev, e, nas circunstâncias atuais, penso que foi muito generoso em seu retrato".

Um estranho eco à Gorie ot uma veio anos depois, em 1836. Após publicar Cartas Filosóficas, Tchaadaiev foi declarado louco. O 
castigo foi excepcional, mas não sem precedentes e sua implementação foi um fato e não apenas moral: ele foi banido.

Os paralelos a figuras conhecidas não param por aí. No famoso discurso de Tchátski "E quem pode julgar?" há um excerto que, sem dúvida, refere-se a um episódio real na vida de Kiulkhelbéker. Tratase de uma denúncia de um professor, de nome Davidov, a Kiulkhelbéker contra a exposição de certos pensamentos mais arrojados em relação à época, em Moscou, em 1823. A denúncia foi tão forte que o Professor ameaçou bani-lo, com proibições e expulsão. O acontecimento, segundo Tyniánov, pode ser visto como diretamente relacionado ao excerto da peça Gorie ot uma ${ }^{159}$ :

"Agora, quando encontram um jovem como nós, Um inimigo dos prazeres materiais, Que não exige posições e nem graus, Que é ávido pelo conhecimento e fita a inteligência pela ciência, Ou que em sua alma o próprio Deus incitou um ardor Para com as criações artísticas, elevadas e magníficas No mesmo instante gritam: bandidagem! Incêndio! E ganham a fama de sonhadores! Perigosos!!" (ATO II)

Kiulkhelbéker viajou pela Europa Ocidental de setembro de 1820 a Agosto de 1821 e, em setembro do mesmo ano foi forçado a partir para Tíflis. Assim, a testemunha da criação e o primeiro ouvinte de Gorie ot uma acabava de chegar da Europa, como Tchátski. Além de ser um grande amigo, Kiulkhelbéker foi figura formadora de opinião a Griboiédov. Uma importante influência foi, sem dúvida, a apresentação da obra de Byron a Griboiédov por parte de

159 Tyniánov, 1968, cit. 
Kiulkhelbéker. Assim, a personalidade de Byron, suas atividades políticas e sociais e, acima de tudo, a luta contra a opinião pública, foram as informações mais excitantes ofertadas por Kiulkhelbéker ${ }^{160}$. Tyniánov nos relembra a semelhança, apontando que "a tragédia pessoal de Byron, a calúnia sobre seu divórcio (que englobava informações acerca de seu estado mental) e imigração de seu país natal - tudo isso encontra raízes profundas tanto no lado pessoal, social e político. A história do drama de Byron é a história de toda a Europa jovem e criativa". A trama de Gorie ot uma, como a vista em uma carta de Griboiédov a Katenin é a história da loucura de Tchátski, dos rumores em torno da sociedade e da emergência da amada. Tudo isso coloca o drama pessoal de Byron muito próximo a Gorie ot uma ${ }^{161}$.

Para Grigóriev, Tchátski representa a "doença da servilidade moral". Doença essa expressa em uma variedade de sintomas, no entanto, sua fonte foi sempre a mesma: o exagero de um fenômeno espectral, uma generalização de acontecimentos particulares. Griboiédov estava livre dessa doença, mas Liérmontov, por exemplo, não estava. É a natureza sublime de Tchátski, que odeia mentiras, o mal, a estupidez. E ele é o rosto heróico da literatura russa; Púchkin o clamou como um homem estúpido, mas o heroísmo, ele não conseguiu eliminar. Tchátski, acima de tudo, é de uma natureza ativa

\footnotetext{
160 Tyniánov, 1968, cit.
}

161 Tyniánov, 1968, cit. 
e honesta, embora a natureza seja apenas de um caráter lutador, ou seja, uma natureza extremamente passional ${ }^{162}$.

Mas quem é Tchátski?

Em suma, um homem inteligente e sensato, ridicularizado perante a sociedade apenas por ter consciência, por distinguir-se de seu meio. Ele é um romântico. Um sonhador. Ele idealiza sua amada. Ele idealiza uma sociedade justa. Seu universo idílico, no entanto, é translúcido e não existe. Sua Sófia é tola e ama tão somente o que Ihe parece fácil, servil (Moltchálin). Sua Moscou encerra-se em uma sociedade de estupidez velada, mas de mecanismos aparentes. Em meio ao embate entre sua visão e a realidade, faz-se o confronto. 0 estranhamento. Nasce a angústia.

Tchátski imagina um mundo em que Sófia está ao seu lado. Sofre por isso. Luta por compreender. Sua ironia é cortante. Tchátski é um idealista e, acima de tudo, um crítico. Ele não sabe viver em outro mundo que não seja o que idealiza. Ele é um estrangeiro em sua própria vida. Incapaz de mudar o universo que deprecia tanto, ele não tenta levantar-se, arregaçar as mangas para um trabalho que alcance a mudança. Ele se limita a falar, seus protestos são apenas verbais. São falas emitidas por um racionalismo detalhado. Por uma preocupação em se fazer ouvir. No entanto, finda sua luta em fracasso, retorna às suas viagens.

162 Grigoriev, 1862, cit. 
Tchátski, imbuído dessa imobilidade, mostra-se incomunicável para com os outros. Em sua primeira conversa com Fámussov, após a volta, no primeiro ato, percebe-se a incomunicabilidade difundida nas bases de Moscou, em que as pessoas não se fazem ouvir, pois ninguém deseja ouvi-las. Ele personifica assim, um novo tipo de homem russo, cuja inteligência e idealismo não alcançam um propósito prático, verdadeiro - o "homem supérfluo"163.

O homem supérfluo, como figura persistente no universo da literatura russa, encontrou expressões mais fortes e mais reconhecidas no âmbito mundial em Púchkin (em Evguiéni Oniéguin), Liérmontov (Pietchórin, em $O$ herói de nosso tempo), Dostoiévski (Ordínov, em A Senhoria), Herzen (Bieltov, em Quem é o culpado?), Turguéniev (Rudin, em Rudin). Como homem supérfluo, Tchátski encontra em sua solidão (de ideias e de coração) toda a forma de expressão de sua distinção em comparação aos que o rodeiam. Ele fala de forma diversa, seus pensamentos fluem de forma diversa - na verdade, é como se ele andasse em caminho oposto a uma multidão de contrários, que procura cortá-lo, empurrá-lo, destruí-lo a cada momento -, até sua fuga final, sua evasão para "um cantinho para os sentimentos ofendidos"164. Até sua fuga é diversa. É cortante, é

\footnotetext{
163 Apesar de Tchátski corresponder ao ideário do "homem supérfluo", esse termo só apareceria em $O$ diário de um homem supérfluo,_de Ivan Turguéniev, em 1850.

164 Esta última relembrada por Dostoiévski em Notas de Inverno sobre Impressões de Verão: "Numa palavra, um tipo absolutamente inútil agora, mas que já foi útil ao extremo. É um fraseador, um tagarela, mas um fraseador sincero, conscienciosamente angustiado com sua inutilidade. Ele se transfigurou agora na nova geração, e nós acreditamos nas forças juvenis, acreditamos que ele não tardará a aparecer novamente, mas não mais num ataque de histeria, como
} 
brusca. Em russo, ela toma forma mais incisiva, propriedade comum à língua sintética. Nós nos sentimos arrebatados pela brusca saída (Карету мне. Карету!, Karietu mnie. Karietu!; Que venha a carruagem, a carruagem!). Tchátski não voltará mais a Moscou. Ele não é capaz de se deparar com o que the é alheio. Tudo isso faz jus ao universo de imobilidade, de um sentimento de impossibilidade. Um mundo muito obscuro e sombrio - do qual ele não quer fazer parte, mas também não sabe como mudá-lo. Ele apenas o critica, evita, mas que fazer? A geração de Tchátski é a geração do ennui, do tédio. Eles não sabem o que fazer. Podemos contrapô-lo aos agitados niilistas da geração de 1860 , mais notadamente as personagens de Tchernitchévski, em seu libelo contra a inação Что делать? (Chto dielat?, Que fazer?). E assim, ele foge. Ele é um raisonneur cuja força ecoa apenas para os espectadores, mas nunca para os que o rodeiam no palco. Sua chegada a Moscou, ou seja, sua volta a Moscou determina sua desgraça.

Mas Gontcharov não o coloca ao lado de Pietchórin e Oniéguin, porque Tchátski, diferentemente deles, apresenta habilidades para escrever e traduzir. Ou seja, sua imobilidade não está no fato de não ter o que fazer, mas, simplesmente, de não saber como fazer. Ele aparece, clareia a escuridão da sociedade - que, no caso, se

naquele baile em casa de Fâmussov, e sim vitorioso, altivo, poderoso, suave e amante. Ele compreenderá então que o cantinho para o sentimento ofendido não fica na Europa, mas talvez diante do nariz, há de encontrar o que fazer e vai começar a fazê-lo". (DOSTOIEVSKI, F.M. O Crocodilo e Notas de Inverno sobre Impressões de Verão, São Paulo: Editora 34, 2000, p. 100). 
particulariza na casa de Fámussov -, mas, somos nós que temos os sentimentos feridos. A verdade bate em nossos rostos e não nos das personagens que saltitam, preocupam-se, discutem infindamente a sua inclinação indestrutível às aparências. Não há nada de relevante nas personagens que nos leve à identificação. Ficamos, durante a peça toda, junto a Tchátski e reprovamos a todos. Reprovamos Sófia por amar a um tolo; reprovamos Moltchálin por ser um tolo, de servilismo enganoso, mas de profunda necessidade aos interesses sociais; reprovamos Fámussov por não "saltar de seu século", por ser tão "fiel ao Clube Inglês", à sua agenda repleta de afazeres inúteis, ao seu ouvido destruído por sua ignorância (pois que ele não ouve o que não quer); reprovamos a Repietilov, por não possuir ideias próprias, preferindo repetir as de outros; reprovamos a Skalozúb, por ser empolado, uma máquina do exército que não pensa nada além de regimentos, ordens e graus.

É a Tchátski que voltamos nosso olhar e nossa condescendência. Nós rimos de sua língua ferina (mas também sofremos por saber que ele é um estranho), nós nos divertimos com as confusões, com as brincadeiras, os provérbios certeiros que aniquilam as máscaras e elevam a ironia. Mas nós amargamos o final injusto da comédia (sem, é claro, deixar de rir da plasticidade e unilateralidade com que Fámussov é construído - ao final, ele não está preocupado com a tristeza de sua filha e com a confusão em que sua família está metida. Ele preocupa-se apenas com as palavras, 
com as fofocas... que irão dizer? "Ah, meu Deus, e a princesa!/ Que dirá Maria Alekseievna?")

Aqui nós poderíamos fazer um paralelo entre as personagens principais de $O$ inspetor geral e Gorie ot uma. A chegada e saída de Khlestakov e Tchátski representam as "tour de clé"165 de seus enredos. Tanto Khlestakov quanto Tchátski marcam o início da trama e selam a fábula, no entanto, as suas saídas não são solução, não trazem iluminação ou tampouco salvação. As suas saídas são como que desesperadas revelações de uma rigidez inflexível, de uma inércia infinita.

A comédia, sob o olhar da desgraça de Tchátski torna-se uma tragédia, pois as luzes não puderam ser acesas. O raisonneur Tchátski chega para iluminar, mas é fulminado pela escuridão de ser inteligente quando o resto todo é ignorante. Ele fala para um universo que não conhece sua língua e que não fará esforço algum para aprendê-la.

Nas críticas variadas que surgiram acerca de Tchátski, Belínski e Púchkin entravaram-se em questões cruciais, a saber dos motivos que levam um homem, o único inteligente em meio a vinte e cinco tolos, a perder o tempo com pessoas que, certamente, estão longe de seu universo intelectual. Entre as dezenas de referências a personagens na peça, há, ao menos, mais de quarenta que, talvez, pudessem fazer par com Tchátski: o primo de Skalozúb, que abdicou

165 Segundo Siniávski, a "tour de clé" é a virada da chave no enredo de O inspetor geral, ponto do qual toda a ação se desenrola. 
da carreira militar e partiu para o campo a fim de ler e estudar; o sobrinho da princesa Tugoukhvskaia, príncipe Fiódor, que estudou no Instituto Pedagógico em Petersburgo, e tornou-se químico e botânico; e os quarenta homens reunidos no Clube Inglês, os quais Repietilov tanto aplaude. Para Púchkin, a simples escolha em permanecer em um meio surdo e apático faz com que Tchátski não seja o mais inteligente da peça. Em uma carta a Bestújev, Púchkin responde que a pessoa mais inteligente da peça, certamente, é Griboiédov. E quem é Tchátski, para Púckhin? É apenas um homem que passou um bom tempo com um gênio, emprestando seus pensamentos, suas tiradas e ironias:

\begin{abstract}
"Agora uma pergunta. Na comédia <<Gorie ot uma >>, quem é a personagem sábia? Resposta: Griboiédov. E será que sabes quem é Tchátski? Um rapaz irado, nobre e bom, que passou algum tempo com um homem muito inteligente (de nome Griboiédov) e que se alimentou de seus pensamentos, brincadeiras e comentários satíricos. Tudo que ele fala é muito inteligente. Mas para quem ele fala tudo isso? Para Fámussov? Para Skalozúb? Para as vovós do baile moscovita? A Moltchálin? Isso é imperdoável. O primeiro sinal de um homem sábio, à primeira vista, é saber com quem está lidando, para não sair por aí, jogando pérolas a Repietilovs e similares". ${ }^{166}$
\end{abstract}

Belínski diz algo mais ou menos similar, mas vai mais a fundo, ao criticar qualquer ato ou pensamento tomado por Tchátski como inteligente:

166 Púchkin em carta a Bestujev: Cf. Cf. obra VÁRIOS AUTORES. A.S. Griboiédov v vospominániakh sovriemiênikov. Moskva: Khudojestvenaia Litieratura, 1980. 
E então: que tipo de personagem profunda é Tchátski? (...) Um bufão idealista que, a cada passo, deprecia tudo que ele menciona. Faz-se, realmente, uma pessoa profunda por ela sair em sociedade, dizendo aos outros, em suas caras, que eles são imbecis e estúpidos? ${ }^{167}$

Apesar da validade das exposições por Púchkin e Belínski, ficanos clara a ideia de que quaisquer dessas afirmações atingem um território exterior à obra e não dizem qualquer coisa sobre o desenvolvimento, ou melhor, o desenrolar da trama. Gontcharov, em seu ensaio sobre a peça, já mencionado acima, encontra em Tchátski uma importante engrenagem da máquina do enredo.

Para ele, Tchátski exerce um papel de grande importância na peça, como uma espécie de catalisador, pois é mola propulsora no movimento dos tipos sociais que se balançam pela peça. Em um artigo, Zenkóvski traça um paralelo entre Griboiédov e o dramaturgo francês Beaumarchais e, melhor dizendo, um paralelo entre Gorie ot uma e As bodas de Fígaro. Diz-se, assim, que Griboiedov aprendeu a arte de construir uma trama com Beaumarchais. Relembrando o prefácio a Bodas de Fígaro, está escrito: "Eu pensei e ainda penso que é impossível alcançar no teatro nem uma moralidade profunda, nem uma comicidade boa e genuína exceto às fortes provisões que a própria quer desenvolver, constantemente advindas do conflito social e da comédia (...) que, menos ambiciosa, não exagera as colisões, porque seus retratos são retirados de nossos costumes, e as tramas,

167 BELÍNSKI Apud KARLINSKY, Simon. Russian Drama: From Its Beginning To The Age Of Púchkin. Califórnia: University Of Carolina Press, 1985.p. 302. 
da vida em sociedade (...) a fábula é uma comédia curta, e qualquer comédia não é nada além do que um apólogo mais longo; a diferença entre elas está no fato de que na fábula, os animais são espertos, posto que em nossa comédia, as pessoas são frequentemente animais, e, o que é pior, animais perversos"168. Para Beaumarchais, tal trama parece suficiente para alcançar o seu retrato social, a sua moralidade em horizonte, mas a Griboiédov, a colisão torna-se exagerada e quase trágica, pois não fosse a presença avalassadora de Tchátski, que tumultua, questiona, a peça tornar-se-ia uma simples comédia de costumes. Tchátski é o animal perverso da fábula, posto que perverte uma ordem natural regente em uma sociedade. No entanto, ele não pode e nem terá forças para carregar essa perversão e, sendo assim, repele a ordem, como se não pudesse respirar naquele mundo sem oxigênio, que não the é como um mundo, como a Terra. Os seus discursos diferem imensamente dos discursos dos que estão ao seu redor. São longos, em frases truncadas e estrutura complexa: compreensão nem sempre imediata, como se, ao invés de falar, ele lesse um texto escrito. Assim bem

\footnotetext{
168 Tynianov, 1968, cit., trecho em tradução nossa. Do original da peça, em francês: "J'ai pensé, je pense encore, qu'on n'obtient ni grand pathétique, ni profonde moralité, ni bon et vrai comique au théâtre, sans des situations fortes, et qui naissent toujours d'une disconvenance sociale dans le sujet qu'on veut traiter.(...) La comédie, moins audacieuse, n'excède pas les disconvenances, parce que ses tableaux sont tirés de nos moeurs, ses sujets de la société (...) La fable est une comédie légère, et toute comédie n'est qu'un long apologue: leur différence est que dans la fable les animaux ont de l'esprit; et que dans notre comédie les hommes sont souvent des bêtes; et qui pis est, des bêtes méchantes" (Prefácio a Bodas de Fígaro, Beaumarchais).
} 
lembra Fámussov, no Ato II: "E olha como ele fala. E fala como se escrevesse".

Para Tchátski, a comédia não passa apenas de um milhão de tormentos - caminho inverso de um aprendizado, como acontece a Alceste, em Molière.

Aproveitando o ensejo acerca de Tchátski e o ensaio Мильион терзаний (Mil'ion Terzanii, Um milhão de tormentos), alcançamos um ponto importante nesse caminho do alargamento da comédia de Griboiédov em relação às regras clássicas das três unidades, pois Gontcharov reconhece a presença das duas tramas: o convencional triângulo amoroso e a visão sócio-política, nas quais Tchátski e suas ideias radicais estão opostas ao mundo reacionário e filisteu de Fámussov, Sófia, Skalozúb, Moltchálin e o resto. O ápice da segunda trama está na aceitação de Tchátski como louco. O ponto mais alto da primeira trama está no desmascaramento do falso e interesseiro Moltchálin.

Essas duas tramas coadunam-se na ideia de oposição de mundos, representada por Tchátski e os outros. Tchátski está contra a sociedade, e, como representante principal dessa sociedade, está Sófia. E a partir de Sófia, a quem Tchátski busca avidamente em seu retorno, desfia-se o bando de tolos, como várias figurações de uma mesma origem, de uma mesma fonte.

Em um momento, Tchátski contra a sociedade e contra Moltchálin/Skalozúb; e em outro, Tchátski e sua desgraça - 
proveniente tanto da morte de seu amor por Sófia, quanto pela morte, para si, de Moscou (No Ato IV, em sua última fala na peça, Tchátski diz: "Eu vou é fugir de Moscou! Não volto mais para cá.").

Contra a estreiteza de possibilidades permitida no universo neoclássico, Hegel, em sua Estética ${ }^{169}$, afirma que "a única regra inviolável é a da unidade de ação". Ele fala da perseguição a um objetivo determinado, o qual não se pôde escapar e, dele, certamente advirão os conflitos que conflagrarão a ação dramática.

Se buscarmos o dramaturgo francês, Mairet, que nos proporcionou a divisão de uma comédia em quatro partes - sendo elas, prólogo, prótese, epítase e catástrofe -, não encontraremos qualquer dificuldade em encaixar Gorie ot uma em suas especificidades. No entanto, a estrutura terá caráter duplo. O ponto de partida para a peça, realmente, é a chegada de Tchátski a Moscou.

Não há prólogo, portanto, partiremos para a prótese. Vejamos a primeira trama, ou seja, a trama do amor de Tchátski por Sófia.

Na prótese (Ato I), sabemos que Sófia está apaixonada por Moltchálin, mas ela, no passado, amava Tchátski. Ele retorna após três anos de ausência, mas ainda não sabe que perdeu sua amada para outro homem.

169 Cf. HEGEL, Georg W. Cursos de Estética. trad. Oliver Tolle; WERLE, Marco Aurélio. São Paulo: Edusp. 
Na epítase (Ato II, III), surge mais um pretendente: Skalozúb. Percebendo a indiferença de Sófia para com ele, Tchátski pensa ser Skalozúb o escolhido. Após o desmaio de Moltchálin, em que Sófia parece muito abalada, Tcháski começa a desconfiar que perdeu seu amor para o homem mais desprezível. Tentando forçar uma confissão por parte de Sófia, Tchátski não consegue esconder o quanto despreza Moltchálin e ela, em retaliação às palavras ferinas do antigo amigo, lança um boato, no baile, à noite, de que ele, de volta da viagem, enlouqueceu. $\mathrm{O}$ nó da peça se instala na difusão do boato por todo o baile.

Na catástrofe (Ato IV), Tchátski percebe o fim de seu amor ao ouvir a declaração, da própria boca de Sófia, de que ela amava mesmo Moltchálin que, ao final, também é desmascarado.

Vejamos a segunda trama, ou seja, a trama de Tchátski contra Moscou.

$\mathrm{Na}$ Prótese (Ato I), Tchátski percebe que as coisas permanecem iguais e passa muito tempo de sua fala discursando sobre a imutabilidade de Moscou. Fámussov quer saber das novidades; em um baile haverá casamento, em outro não; as pessoas querem escrever seus versos no caderninho; falam em uma mistura de russo e francês; ler e escrever são tidos como um crime; hoje preferem os que vivem mudos; entre outras ideias.

$\mathrm{Na}$ epítase (Ato II, III), acontece o grande confronto de Tchátski com Moscou, expressos em seus encontros com as figuras 
emblemáticas de Fámussov, Skalozúb e Moltchálin. O primeiro representa o aristocrata que pensa apenas no falatório dos círculos e de que maneira conseguirá ascender mais em adulações aos mais validos; o segundo representa o oficial bestializado, tornado engrenagem apenas para marchar, não podendo, sequer, pensar em nada que esteja fora do âmbito militar; e o terceiro, o empregado de grau menor, que, em prol da imutabilidade da sociedade, deve ficar calado para não provocar quaisquer arestas impolidas. Ao final, o boato de Tchátski como louco é aceito por todos, pois, segundo Fámussov, ele não aceita as autoridades; ele mandou o marido de Natália Dmitriévna descansar no campo; e bebe, bebe mais do que devia.

Na catástrofe (Ato IV), levado pelo momento em que todos se afastam dele, em seu grande discurso-libelo contra a França, Tchátski sai, a fim de ir para casa. As lembranças e as tristezas de seu retorno e as esperanças que tinha em encontrar a Moscou de sua infância se desfazem. Ele, então, escuta da boca dos próprios convidados, que todos cogitam sua loucura. Isso o enraivece e faz com que ele verta sua bílis por todos os elementos da sociedade. Ao final, decreta o fim de Moscou, ao dizer-Ihe um fim.

Há, como pudemos ver, duas peças, ou melhor, duas grandes tramas, a se aglutinarem em uma só. No entanto, é possível visualizá-las como produtos separados e, se tentássemos, seria possível reescrevê-las também em separado. 
Sendo assim - contrariando a noção, exposta acima, de que a unidade de ação deve apenas seguir uma única trama principal, com poucas ou nenhuma trama secundária -, obtemos a grande ruptura de Griboiédov e sua Gorie ot uma. Ela não pode ser considerada genuinamente neoclássica porque sua trama - uma aglutinação de duas outras tramas, de igual força - é complexa.

Para Renata Pallottini ${ }^{170}$, as unidades foram postas de lado, como também nos diz Hegel, restando apenas a ação dramática, cuja força é engrandecida pelo movimento do conjunto de conflitos. Nas tramas de Tchátski X Sófia e Tchátski X Moscou, encontramos diversas colisões e, juntas, a fábula se torna dupla, devendo ser delineada de maneira mais específica. Os clímax e desenlaces acontecem, em mesmo instante, para as duas tramas.

Para Hegel, se as ações se ramificarem "em ações episódicas e em personagens secundárias, a unidade pode ser mais ou menos estreita, mais ou menos lassa." Pensando nisso, o surgimento de Repietilov parece totalmente deslocado de ambas as tramas principais e, poder-se-ia pensar, quase descartável. No entanto, como descartar a personagem mais estranha, mais burlesca, um perfeito bufão, na melhor linhagem do trickster, tão recorrente na literatura russa? Aresta ou não, Repietilov só acrescenta na comicidade da peça e é como se necessitássemos de uma figura final,

170 Cf. PALLOTTINI, Renata. Introdução à Dramaturgia. São Paulo: Série Princípios, Editora Ática, 1988, pp.8-16. 
a denunciar que por aí anda um círculo secreto, com uma dúzia de cabeças fervilhantes, a agitar!

Já em forma de manuscrito, a peça recebia críticas positivas. Para N. A Polievoi, nunca uma comédia havia alcançado tais penetrantes ideias e tais retratações reais da sociedade russa. No início de sua carreira como jornalista, Belínski, crítico literário renomado, disse: "Que poder sarcástico e letal, que ironia mordaz, que análises das personagens e da sociedade e que linguagem, que verso enérgico, sintético, fulminante e tão russo". No entanto, em 1840, Belínski chegou à conclusão de que a comédia deveria ser rejeitada. Esta nova ideia acerca da peça também viria a ser modificada, tendo, ao final, uma posição mais definitiva, ou seja, a de que a peça teve enorme representatividade e significância para o desenvolvimento do Teatro na Rússia.

Houve uma época em que Belínski devotava especial atenção e crença à força de Gorie ot uma. Mas, após a flama de O Inspetor Geral, passou a diminuir a força que devotava à criação da obraprima de Griboiédov. Belínski diz: "aquela era a fase do desenvolvimento de nossa consciência crítica." Era a época de Rudin, Tchátski e Bieltov.

Em uma famosa carta do final de janeiro de 1825, Púchkin escreve a Aleksandr Bestújev (grande amigo de Griboiédov ${ }^{171}$ ) uma

171 Da mesma maneira, Karlinsky também afirma que, como muitos versos tornaram-se populares, pode existir quem não saiba a origem. (KARLINSKY, Simon. 
das críticas mais famosas à peça. Nela, Púchkin prevê a popularização de grande parte dos versos e diz que, certamente, metade deles se tornará provérbios.

Em 1870, no mesmo ensaio sobre a peça, já mencionado acima, Gontcharov acredita que a obra de Griboiédov consegue ultrapassar, de certa forma, as famosas obras de Púchkin e Fonvízin, porque suas personagens guardam uma vivacidade que pode se sobressair das letras para achegar-se à vida.

Segundo Karlinsky, Gorie ot uma é, certamente, a obra mais citada na história da literatura russa, com exemplos em textos de Dostoiévski, Marina Tsvetáieva, Boris Pasternak, Vladimir Nabokov, Velimir Khlébnikov, entre outros.

Aleksandr Blok, já em 1915, colocou Griboiédov ao lado de Púchkin, sugerindo que ambos haviam "estabelecido uma firme base para o edifício do verdadeiro esclarecimento ${ }^{1172}$.

Russian Drama: From Its Beginning To The Age Of Púchkin. Califórnia: University Of Carolina Press, 1985.p.287.)

172 GRIBOIEDOV,A.S. Polnoie Sobránie Sotchiniêni A.S. Griboiedova. S-P.: Izdanie A.F. Marka, 1892. 


\section{REFERÊNCIAS BIBLIOGRÁFICAS}

Obras de Aleksandr Griboiedov:

GRIBOIÉDOV, A.S. Gorie ot uma. Moskva: Russky Yazik, 1984.

GRIBOIÉDOV, A.S. Polnoie Sobránie Sotchiniêni A.S. Griboiedova. SP.: Izdanie A.F. Marka, 1892.

GRIBOÏEDOV, Alexandre. Du malheur d'avoir de l'esprit. Paris: Babel, 2007.

GRIBOJEDOV, Alessandro. L'Ingegno, Che guaio!. Milano: Rizzoli Editore, 1954.

GRIBOJEDOV, Aleksandr. Lijden door verstand. tradução de Michel Lambrecht. Antuérpia: Benerus, 2001.

GRIBOYEDOV, Alexander. "Woe from wit". In: The Government Inspector and other russian plays. Denis Fonvizin, Alexander Griboyedov, Nikolai Gogol, Ostrovsky. New York: Penguin Classics, 1990. 


\section{Obras sobre Aleksandr Griboiédov e Gorie ot uma:}

AIKHENVALD, I. I. Griboiedov - Siluiéty russkikh pissátieliei. V. 3 vyp. M., 1906 - 1910; 2-i izd. M., 1908 - 1913.

BELÍNSKI, V. G. "Gorie ot uma". Komiedia $v$ 4-kh dieistviakh, $v$ stikhakh. Sotchiniêni. A. C. Griboiedova, 1839. http://az.lib.ru/b/belinskij_w_g/text_0020.shtml, primeiro acesso em 20/04/2007.

BONAMOUR, Jean. A.S. Griboyedov et la vie littéraire de son temps - Paris: 1965.

GONTCHAROV, I. A. "Мильон терзаний" (Mil'on tierzanii, Um milhão de tormentos). Sobránie Sotch., T. VIII, Moskva: 1952. (http://az.lib.ru/g/goncharow_i_a/text_0040.shtml; acesso em 20/04/2007).

GRIGORIEV, A.A. Po povodu novovo izdaniia vieschi, "Gorie ot uma". Spb. 1862. http://az.lib.ru/g/grigorxew_a_a/text_0330.shtml, acesso em 25/08/2009. 
KELLY, Laurence. Diplomacy and Murder in Tehran: Alexander Griboyedov and Imperial Russia's Mission to the Shah of Persia. London: I.B. Tauris Publishers, 2002.

LUNATCHARSKI, Anatóli. A. S. Griboiédov v ruskoi kritike: Sbornik st. / Sost. Vstup. st. I primietch. A. M. Gordina. - M.: Goslitizdat, 1958, pp. 324-342.

(http://az.lib.ru/l/lunacharskij_a_w/text_0090.shtml, primeiro acesso em 25/08/2009).

MESCHERIAKOV, V.N. Novoie o Griboiédovie, Russkaia Litieratura, No.1， 1985. http://az.lib.ru/g/griboedow_a_s/text_0120.shtml, primeiro acesso em 15/01/2010).

NADIÉJDIN N. I. "Gorie ot uma", komiedia v tchetyriekh diestviakh A. Griboiedova. Sbornik st. / Sost., vstup. st. I primietch. A. M. Gordina. M.: Goslitizdat, 1958. pp. 60-69. http://febweb.ru/feb/griboed/critics/krit/krit09.htm, acesso em 25/08/2009.

NAZARIENKO, M. "Tyniánov o Griboiedovie: nauka i litieratura". Russki Izyk, litieratura, kul'tura v chkolie i vizie (K.), 2006, N.4, pp. 17-21 (http://az.lib.ru/t/tynjanow_j_n/text_0230.shtml, primeiro acesso em 15/01/2010). 
NECHKINA, M.V. Dvijenie diekabristov. Tom. 1 i 2 - Moskva: Izdatielstvo Akadiemii Nauk URSS, 1955.

A. S. Griboiedov i diekabristy. Izd. 3-ie.

Moskva: URSS, M, 1971.

ORLOV, V. "A.S. Griboiédov". Sotchiniênia. M.-L., 1959. http://az.lib.ru/g/griboedow_a_s/text_0040.shtml, acesso em 26/08/2009.

PIKSANOV, N. K. Tvortcheskaia istoria <<Gorie ot uma $>>$ $<<$ Nauka $>>$, M., 1971.

POLIEVOI, K. "Gorie ot uma": komiedia v tchetyriex dieistiviakh, $v$ stikhakh. Sotchiniêni Aleksandra Sergueievitcha Griboiedova. M. 1833. V.t. A. Semiena, p. 167. in 8. (http://az.lib.ru/p/polewoj_k_a/text_0130.shtml; acesso em $13 / 02 / 2010)$.

SCHEGOLIEV, P. E. Piervientsy Russkoi Svobody. Vstupit. Statia I Kommient. A.S. Griboiedov i Diekabristy. I. N. Emielianova. M.: Sovriemiênik, 1987, http://az.lib.ru/s/shegolew_p_e/text_0140.shtml, primeiro acesso em 26/08/2009). 
TYNIÁnOV, I. Siujet "Goria ot uma". V. Kn: Puchkin i evo sovriemieniki.Moscou: $<<$ Nauka $>>, 1968$, (http://az.lib.ru/t/tynjanow_j_n/text_0150.shtml,primeiro acesso em 10/03/2009).

Smiert Vazir-Mukhtara. Sotchiniênia: V 2-kh t. T.2.

L.: Khudojestvienaia litieratura, 1985.

UCHAKOV, V. A. Moskovskii bal, trietie dieistvie iz komiedii "Gorie ot uma": (Bienefis g-ji N. Repinoi) A. Griboiedova v ruskoi kritike: Sbornik st./Sost., vstup. st. I primietch. A. M. Gordina. M.: Goslitizdat, 1958. pp. 93-94, trecho em tradução nossa, http://az.lib.ru/u/ushakow_w_a/text_0030.shtml, acesso em 26/08/2009.

VÁRIOS AUTORES. A.S. Griboiédov v vospominániakh sovriemiênikov. Moskva: Khudojestvenaia Litieratura, 1980 (http://az.lib.ru/g/griboedow_a_s/text_0060.shtml, primeiro acesso em 15/01/2010).

ZENKÓVSKI, O.I. "Gorie ot uma", komiedia $\mathbf{v}$ tchetyriekh diestviakh A. Griboiedova. Sbornik st./Sost., vstup. st. I primietch. A. M. Gordina. M.: Goslitizdat, 1958. pp. 93-94. http://az.lib.ru/s/senkowskij_o_i/text_0100.shtml, acesso em 25/08/2009. 
Sobre a História e Literatura Russa:

AKSÁKOV, K. S. "Lomonóssov $v$ istorii russkoi litieratury i russkovo izyka". Litieraturnaia kritika. M.: Sovriemiênik, 1981, http://az.lib.ru/a/aksakow_k_s/text_0230.shtml, primeiro acesso em 14/05/2010).

BELÍNSKI, V.G. Kantemir. Sobránie Sotchiniêni v triekh tomakh. T. II. M., 1948, trecho em tradução nossa, http://az.lib.ru/b/belinskij_w_g/text_1220.shtml, acesso em 14/05/2010).

BERNARDINI, Aurora F. "Puchkin e o começo da literatura russa" (in. Caderno de Literatura Russa, n.1, São Paulo: Ateliê Editorial, 2004, p. 34).

BROWN, William E. A history of russian literature of the Romantic Period: Volume One. Michigan: Ardis Publishers, 1986.

CAMPOS, Haroldo - "Púchkin: A poesia da Gramática" (in. Caderno de literatura e cultura russa, n. 1, São Paulo: Ateliê Editorial, 2004, p.62). 
CAVAliere, Arlete. Teatro Russo: Percurso para um estudo da paródia e do grotesco. São Paulo: Humanitas, 2009.

DOSTOIEVSKI, F.M. O Crocodilo e Notas de Inverno sobre Impressões de Verão, São Paulo: Editora 34, 2000, p. 100.

FIGES, Orlando. Natasha's Dance: a cultural history of Rússia. New York: Picador, 2002.

KARLINSKY, Simon. Russian drama: from its beginning to the age of Pushkin. Califórnia: University of Carolina Press, 1985.

MASARYK, Thomas. The Spirit of Russia: Studies in History, Literature and Philosophy. trans/tr, Cedar Paul - trans/tr, W. R. trans/tr, Z. Lee - trans/tr. Boston: Allen \& Unwin, 1919.

MAZOUR, Anatole G. The First Russian Revolution, 1825: The Decembrist movement. California: University of California Press, 1964.

MILIUKOV, Paul. Histoire de Russie, tome II: Les successeurs de Pierre Le Grand, de I'Autocracie Appuyee sur la Noblesse a L'Autocracie Bureaucratique. Paris: Librairie Ernest Leroux, 1932. 
MOISSAYE, J. O. Guide to Russian literature (1820-1917). New York: Harcourt, Brace and Home, 1920.

MOSER, Charles. The Cambridge History of Russian Literature. Cambridge: Cambridge University Press, 1999.

NAZAREVSKI, V. V. Histoire de Moscou: depuis les origins jusqu'a nos jours. traduit du russe par Serge Kaznakoff . Paris: Payot, 1932.

OLIVER, M. Sayler. The Russian Theatre. New York: Brentano's, 1922.

PÚCHKIN, Aleksandr. Eugênio Oneguin. trad. Dário Moreira de Castro Alves. Moscou: Grupo Editorial <<Azbooka-Atticus>>, 2008.

SINIÁVSKI, A. "Chapitre II, Deux tours de $<<$ revizor $>>$ avec la clé d'argent". In: Dans L'Ombre de Gogol. Traduit Du russe par Georges Nivat. Paris; Éditions du Seuil.

STANISLÁVSKI, Constantin. A preparação do ator. Tradução de Pontes de Paula Lima. Rio de Janeiro: Civilização Brasileira, 2001. 
A criação do papel. Tradução de

Pontes de Paula Lima. Rio de Janeiro: Civilização Brasileira, 2001

WALICKI, Andrzej. A History of Russian Thought: From the

Enlightment to Marxism. California: Stanford University Press, 1979.

VÁRIOS AUTORES (org. Arlete Orlando Cavaliere, Elena Vássina, Homero Freitas de Andrade e Noé Silva). Caderno de Literatura e Cultura Russa. São Paulo: Ateliê Editorial, 2004. 
Sobre o teatro e o Neoclassicismo:

ARISTÓTELES. "A fábula". Traduzido do original por Jacques Scherer. "Poética" (org. Monique Borie, Martine de Rougemont, Jacques Scherer). In: Estética Teatral: textos de Platão a Brecht. tradução de Helena Barbas. Lisboa: Fundação Calouste Gulbenkian, 2004.

"Estruturas da fábula. Traduzido do original por

Jacques Scherer. "Poética" (org. Monique Borie, Martine de Rougemont, Jacques Scherer). In: Estética Teatral: textos de Platão a Brecht. tradução de Helena Barbas. Lisboa: Fundação Calouste Gulbenkian, 2004.

BEAUMARCHAIS, Pierre. La folle journée ou Le mariage de Fígaro. (http://www.gutenberg.org/files/20577/20577-h/20577h.htm, acesso em 20/07/2010).

BENTLEY, Eric. A experiência viva do teatro. tradução de Álvaro Cabral. Rio de Janeiro: Zahar Editores, 1967.

BERGSON, Henri. O riso: Ensaio sobre a significação da comicidade. tradução de Ivone Castilho Benedetti. São Paulo: Martins Fontes, 2004. 
BOILEAU, Nicolas. "A emoção trágica". "Arte Poética" (org. Monique Borie, Martine de Rougemont, Jacques Scherer). In: Estética Teatral: textos de Platão a Brecht. tradução de Helena Barbas. Lisboa: Fundação Calouste Gulbenkian, 2004.

. "Para uma comédia aristocrática". "Arte Poética" (org. Monique Borie, Martine de Rougemont, Jacques Scherer). In: Estética Teatral: textos de Platão a Brecht. tradução de Helena Barbas. Lisboa: Fundação Calouste Gulbenkian, 2004.

CORNEILLE, Pierre. "Unidade de acção". "Discursos" (org. Monique Borie, Martine de Rougemont, Jacques Scherer). In: Estética Teatral: textos de Platão a Brecht. tradução de Helena Barbas. Lisboa: Fundação Calouste Gulbenkian, 2004. . "Unidade de lugar". Discursos" (org. Monique Borie, Martine de Rougemont, Jacques Scherer). In: Estética Teatral: textos de Platão a Brecht. tradução de Helena Barbas. Lisboa: Fundação Calouste Gulbenkian, 2004.

COSTA, Lígia. A poética de Aristóteles: Mimese e verossimilhança - São Paulo: Editora Ática, 2006. 
MAIRET, Jean. "Os géneros do teatro". "Prefácio de Silvanira". (org. Monique Borie, Martine de Rougemont, Jacques Scherer). In: Estética Teatral: textos de Platão a Brecht. tradução de Helena Barbas. Lisboa: Fundação Calouste Gulbenkian, 2004.

. "As três unidades". "Prefácio de Silvanira". (org. Monique Borie, Martine de Rougemont, Jacques Scherer). In: Estética Teatral: textos de Platão a Brecht. tradução de Helena Barbas. Lisboa: Fundação Calouste Gulbenkian, 2004.

MATTHEWS, Brander. A Book about the Theater. New York. C. Scribner's Sons, 1916.

MOLIÈRE. O misantropo/O tartufo. tradução de Jenny Klabin Segall. 2a edição. São Paulo: Martins Fontes, 2005.

- O médico volante/As preciosas ridículas/Os

ciúmes do Barbouillé. tradução de Sergio Flaksman. São Paulo: Editora Peixoto Neto, 2007.

O avarento. tradução de Bandeira Duarte. Rio de Janeiro: Edições de Ouro, 1975. 
PALLOTTINI, Renata. Introdução à Dramaturgia. São Paulo: Série Princípios, Editora Ática, 1988.

VÁRIOS AUTORES (org. Monique Borie, Martine de Rougemont, Jacques Scherer). Estética Teatral: textos de Platão a Brecht. tradução de Helena Barbas. Lisboa: Fundação Calouste Gulbenkian, 2004.

HEGEL, Georg W. Cursos de Estética. trad. Oliver Tolle; WERLE, Marco Aurélio. São Paulo: Edusp, 2004.

VOLTAIRE. "A mistura dos géneros". "Obras completas". (org. Monique Borie, Martine de Rougemont, Jacques Scherer). In: Estética Teatral: textos de Platão a Brecht. tradução de Helena Barbas. Lisboa: Fundação Calouste Gulbenkian, 2004. 
Sobre tradução:

ARROJO, Rosemary (org.). O signo desconstruído: implicações para a tradução, leitura e ensino. Campinas, SP : $2^{a}$ edição Pontes, 2003.

AUBERT, Francis. As in(fidelidades) da tradução: servidões e autonomia do tradutor/ Campinas,SP: Editora da UNICAMP, 1993.

CAMPOS, Geir. O que é tradução?, São Paulo: Editora Brasiliense, 1986.

PAES, José P. Tradução: A ponte necessária, aspectos e problemas da arte de traduzir. São Paulo: Editora Ática, 1990. 
